UNIVERSIDADE DE SĀO PAULO INSTITUTO DE GEOCIENCIAS

DEDALUS - Acervo - IGC

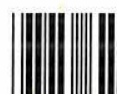

30900005339

\title{
GEOCRONOLOGIA DOS EVENTOS MAGMÁTICOS, SEDIMENTARES E METAMÓRFICOS NA REGIÃO DO QUADRILÁTERO FERRÍFERO, MINAS GERAIS
}

Carlos Mauricio Noce

TESE DE DOUTORAMENTO

COMISSÃO JULGADORA

nome

ass.

Presidente :

Examinadores:

\begin{tabular}{l} 
Wilson Teixeira \\
Marly Babinski \\
\hline Sílvio Roberto Farias Vlach \\
\hline Maurício Antonio Carneiro \\
\hline Pierre Sabaté
\end{tabular}

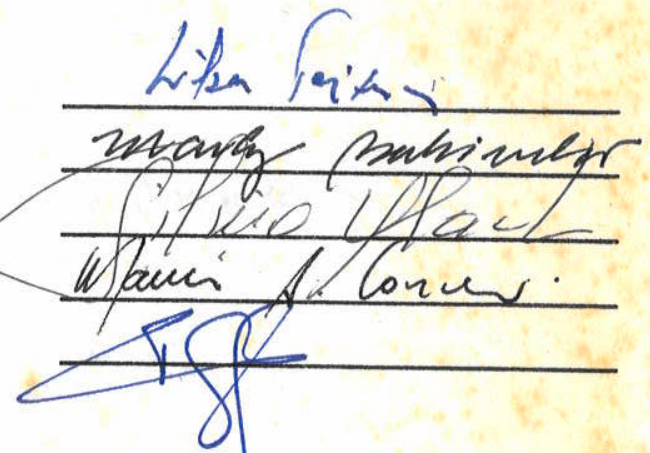

São Paulo 1995

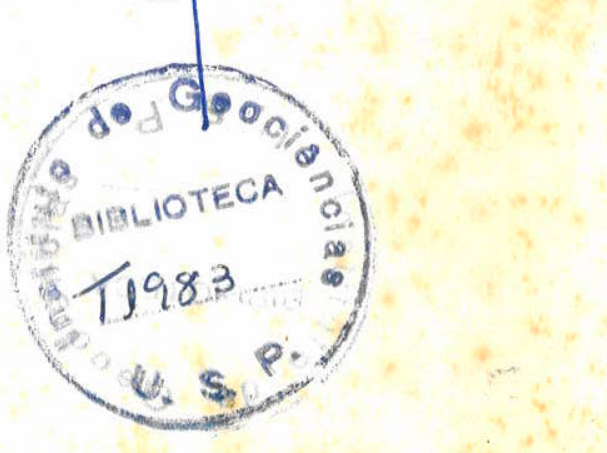




\section{UNIVERSIDADE DE SÃO PAULO INSTITUTO DE GEOCIENCIAS}

\section{GEOCRONOLOGIA DOS EVENTOS MAGMÁTICOS, SEDIMENTARES E METAMÓRFICOS NA REGIÃO DO QUADRILÁTERO FERRÍFERO, MINAS GERAIS}

Carlos Mauricio Noce

Orientador: Prof. Dr. Wilson Teixeira

TESE DE DOUTORAMENTO

Programa de Pós-Graduação em Geoquímica e Geotectônica

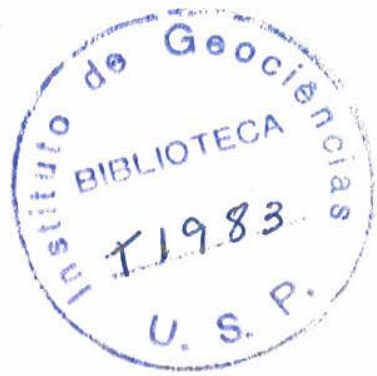

São Paulo

1995 
Só uns poucos tomam, por todos os demais, o encargo nobre e pleno de responsabilidade de custodiar a "escritura sagrada" da Terra, de lê-la e interpretá-la, pois o enlace consciente do homem com sua estrela está confiado a uma ciência especial...

Hans Closs (1885-1951, "Diálogo com a Terra") 


\section{ÍNDICE}

\begin{tabular}{|c|c|c|}
\hline & Capítulo 1 & \\
\hline & INTRODUÇÃO & 1 \\
\hline 1.1 & APRESENTAÇÃO E OBJETIVOS DO TRABALHO & 1 \\
\hline 1.2 & ÁREA INVESTIGADA & 2 \\
\hline 1.3 & METODOLOGIA DE TRABALHO & 4 \\
\hline 1.4 & $\begin{array}{l}\text { A ESCALA DE TEMPO DO PRÉ-CAMBRIANO E OS CICLOS TECTONNICOS } \\
\text { DA PLATAFORMA SUL-AMERICANA }\end{array}$ & 7 \\
\hline \multirow[t]{3}{*}{1.5} & AGRADECIMENTOS & 8 \\
\hline & Capítulo 2 & \\
\hline & MÉTODOS ANALÍTICOS EM GEOCRONOLOGIA & 10 \\
\hline $\begin{array}{l}2.1 \\
2.1 .1 \\
2.1 .2 \\
2.1 .3 \\
2.1 .4\end{array}$ & $\begin{array}{l}\text { GEOCRONOLOGIA U-Pb DE ALTA PRECISÃO } \\
\text { Preparação das amostras } \\
\text { Lavagem, pesagem, dissolução dos grãos minerais e extração do U e Pb } \\
\text { Espectrometria de massa e resultados analiticos } \\
\text { Considerações sobre o processo de alteração dos zircões }\end{array}$ & $\begin{array}{l}10 \\
11 \\
12 \\
13 \\
14\end{array}$ \\
\hline 2.2 & OBTENÇÃO DE IDADES ${ }^{207} \mathrm{~Pb} / 206 \mathrm{~Pb}$ POR LP-ICPMS & 15 \\
\hline 2.3. & MÉTODO ISOCRÔNICO Pb-Pb EM MINERAL & 16 \\
\hline 2.4 & MÉTODO Sm-Nd & 17 \\
\hline 2.5 & MÉTODOS Rb-Sr E K-Ar & 17 \\
\hline \multirow[t]{3}{*}{2.6} & $\begin{array}{l}\text { CONSIDERAÇÕES SOBRE AS TEMPERATURAS DE FECHAMENTO DE } \\
\text { SISTEMAS ISOTÓPICOS }\end{array}$ & 18 \\
\hline & Capítulo 3 & \\
\hline & $\begin{array}{l}\text { CONTEXTO GEOLÓGICO E ACERVO } \\
\text { GEOCRONOLÓGICO }\end{array}$ & 19 \\
\hline 3.1. & ASPECTOS GERAIS DA GEOLOGIA DO QUADRILÁTERO FERRIFERO & 19 \\
\hline $\begin{array}{l}3.2 \\
3.2 .1 \\
3.2 .2 \\
3.2 .3 \\
3.2 .4\end{array}$ & $\begin{array}{l}\text { ACERVO GEOCRONOLÓGICO } \\
\text { Determinações } \mathrm{Rb}-\mathrm{Sr} \text { e } \mathrm{K}-\mathrm{Ar} \\
\text { Determinações } \mathrm{Pb}-\mathrm{Pb} \\
\text { Determinações } \mathrm{Sm}-\mathrm{Nd} \\
\text { Determinações } \mathrm{U}-\mathrm{Pb}\end{array}$ & $\begin{array}{l}24 \\
24 \\
25 \\
26 \\
26\end{array}$ \\
\hline \multirow[t]{3}{*}{3.3.} & ARCABOUÇO GEOLÓGICO REGIONAL E EVOLUÇÃO & 28 \\
\hline & Capítulo 4 & \\
\hline & $\begin{array}{l}\text { TERRENOS GRANITO-GNÁISSICOS: GEOLOGIA E } \\
\text { GEOCRONOLOGIA DO COMPLEXO BELO HORIZONTE }\end{array}$ & 33 \\
\hline 4.1. & INTRODUÇÃO & 33 \\
\hline 4.2 & ASPECTOS GEOLÓGICOS & 34 \\
\hline
\end{tabular}


4.3. PETROQUÍMICA $\quad 37$

4.3.1. Gnaisse Belo Horizonte $\quad 37$

4.3.2. Plutonitos granitóides (Granito Santa Luzia. Granito General Carneiro.

$\begin{array}{ll}\text { 4.4. GEOCRONOLOGIA } & 50\end{array}$

4.4.1. Gnaisse Belo Horizonte e mobilizado migmatítico $\quad 50$

4.4.1.1. Determinaçŏes U-Pb $r$

4.4.1.2. Determinações Rb-S.r

\begin{tabular}{ll} 
4.4.2. & Granito Santa Luzia \\
\hline 4.4 .3$. & 57
\end{tabular}

$\begin{array}{ll}\text { 4.4.3. } & 58\end{array}$

4.4.4. Determinações K-Ar para o Complexo Belo Horizonte 60

4.5. DISCUSSÃO DOS RESULTADOS 61

\section{Capítulo 5}

\section{PLUTONITOS GRANITÓIDES (E PEGMATITOS) DO} ARQUEANO TARDIO E PROTEROZÓICO

5.1. INTRODUÇÃO

5.2. GRANITO MORRO DA PEDRA E GRANITO CÓRREGO DO BRUMADO (REGIÃO SETENTRIONAL DO QUADRILÁTERO FERRIFERO)

5.2.1. Aspectos geológicos

5.2.3. Geocronologia 66

5.2.3.1. Determinações $U-P b \quad 66$

5.2.3.2. Determinações $\mathrm{Pb}-\mathrm{Pb} \quad 69$

$\begin{array}{ll}\text { 5.2.4. Discussão dos resultados } & 71\end{array}$

5.3. GRANITÓIDES E PEGMATITOS DA REGIÃO MERIDIONAL DO
QUADRILÁTERO FERRIFERO

5.3.1. Aspectos geológicos $\quad 71$

$\begin{array}{ll}\text { 5.3.1.1. Região de Salto do Paraopeba } & 73\end{array}$

5.3.1.2. Distrito Manganesifero de Conselheiro Lafaiete $\quad 74$

5.3.2. Petroquímica $\quad 76$

5.3.2.1. $\quad$ Granito Salto do Paraopeba $\quad 76$

\begin{tabular}{ll} 
5.3.2.2. & Batólito Alto Maranhão \\
\hline 5.3.3. & 78
\end{tabular}

\begin{tabular}{ll} 
5.3.3. & Geocronologia \\
\hline 5.3.3. & 79
\end{tabular}

5.3.3.1. $\quad$ Granito Salto do Paraopeba: Determinações U-Pb 79

5.3.3.2. Pegmatito de Salto do Paraopeba: Determinações U-Pb e Pb-Pb 81

5.3.3.3. Batólito Alto Maranhão: Determinações U-Pb, Sm-Nd, Rb-Sr e K-Ar 83

5.3.3.4. Veios quartzo-feldspáticos (com monazita) da Falha do Engenho:
Determinaços $U_{\sim} P b$

5.3.4. Considerações sobre a evolução geológica da região meridional do Quadrilátero Ferrifero

\section{Capítulo 6 \\ EVENTOS DE SEDIMENTAÇÃO: CRONOLOGIA COM BASE NA DATAÇÃO DE ZIRCÕES DETRÍTICOS}

6.1. DATAÇÃO DE ZIRCÕES DETRITICOS: DADOS OBTIDOS E DISCUSSÃO 92

6.2. CRONOLOGIA DA SEDIMENTAÇÃO 97

6.2.1. Supergrupo Minas 97

6.2.1.1. Grupos Caraça e Itabira 97 
6.2.1.2. Crupo Piracicaba $\quad 99$

$\begin{array}{lr}\text { 6.2.1.3. Grupo Sabará } & 100\end{array}$

$\begin{array}{lll}\text { 6.2.2. } & \text { Grupo Itacolomi } & 101\end{array}$

Capítulo 7

ALGUMAS CONSIDERAÇÕES SOBRE EVENTOS DE CISALHAMENTO E MINERALIZAÇÃO AURIFERA COM BASE EM DETERMINAÇÕES U-Pb EM RUTILO E TITANITA

7.1. GEOLOGIA DA ÁREA INVESTIGADA (REGIÃO NORDESTE DO QUADRILÁTERO FERRIFERO) E AMOSTRAGEM 103

$\begin{array}{lll}\text { 7.2. GEOCRONOLOGIA } & 104\end{array}$

7.2.1. Determinações $\mathrm{U}-\mathrm{Pb}$ em rutilo e resultados obtidos $\quad 104$

7.2.2. Determinação U-Pb em titanita do gnaisse de Cocais 106

$\begin{array}{ll}\text { 7.3. DISCUSSÃO DOS RESULTADOS } & 108\end{array}$

\section{Capítulo 8}

\section{CONCLUSÕES}

$\begin{array}{lll}\text { 8.1. EVOLUÇÃO CRUSTAL NO ARQUEANO } & 109\end{array}$

8.1.1. Formação dos primeiros núcleos continentais (3.300-3.000 Ma) 109

8.1.2. Crescimento continental e eventos tectono-termais $(3.000-2.850 \mathrm{Ma}) \quad 111$

$\begin{array}{ll}\text { 8.1.3. Eventos do Neoarqueano (2.800-2.600 Ma) } & 112\end{array}$

8.1.3.1. O evento de 2.780-2.700 Ma (Evento Rio das Velhas) 113

8.1.3.2. Eventos magmáticos finais e a consolidação da plataforma arqueana $\quad 114$

8.2.1. Considerações sobre a natureza da tectônica transamazônica $\quad 116$

$\begin{array}{lll}\text { 8.2.2. Uma visão regional do cinturão transamazônico (Cinturão Mineiro) } & 117\end{array}$

8.3. EVOLUÇÃO MESO E NEOPROTEROZÓICA 118

\section{ÍNDICE DAS FIGURAS}

Figura 1: Localização da área investigada 3

Figura 2: $\quad$ Principais feições fisiográficas (cristas de serra) e rede hidrográfïca do 3

Figura 3: $\quad$ Mapa geológico do Quadrilátero Ferrífero $\quad 20$

Figura 4: $\quad$ Delimitação atualizada e significado dos limites do Cráton do São Francisco 29

Figura 5: Mapa estrutural do Quadrilátero Ferrifero $\quad 31$

Figura 6: $\quad$ Mapa geológico do Complexo Belo Horizonte $\quad 35$

Figura 7: Classificação do Gnaisse Belo Horizonte segundo o diagrama Ab-An-Or $\quad 40$

Figura 8: $\quad$ Diagrama de variação de elementos-traço, normalizados para o manto primitivo, 40

Figura 9: Curvas de ETR, normalizadas para condritos, para o Gnaisse Belo Horizonte 41 
Figura 10: Curvas de ETR. normalizadas para condritos, para o gnaisse migmatítico

e mobilizado félsico do mesmo afloramento

Figura 11 Diagrama comparativo entre a curva média de ETR para o Gnaisse Belo Horizonte, as curvas médias para tonalitos e trondhjemitos arqueanos de alto $\mathrm{Al}_{2} \mathrm{O}_{3}$ e baixo $\mathrm{Al}_{2} \mathrm{O}_{3}$ e para o Gnaisse Alberto Flores

Figura 12: $\quad$ Diagrama $(\mathrm{Yb})_{\mathrm{N}} \times(\mathrm{La} / \mathrm{Yb})_{\mathrm{N}}($ Martin 1987) mostrando a variação no conteúdo em ETR no tempo geológico

Figura 13: Diagrama de variação de elementos-traço, normalizados para o manto primitivo, para o Granito Santa Luzia e o Granito General Carneiro

Figura 14: (a) Curvas de ETR, normalizadas para condritos, para o Granito Santa Luzia e o Granito General Carneiro (b) Diagrama comparativo entre as curvas de ETR para o Granito Santa Luzia e o Granito General Carneiro e a curva média para o Gnaisse Belo Horizonte

Figura 15: Curva de ETR, normalizada para condritos, para o Granodiorito Ibirité

Figura 16 (a) Diagrama comparativo entre a curva média de ETR para o Granito Santa Luzia e o Granito Mpageni (b) Diagrama comparativo entre a curva média de ETR para o Granito General Carneiro e o Granito Sicunusa

Figura 17: Localização das amostras com determinações geocronológicas no

Complexo Belo Horizonte

Figura 18: Diagrama concórdia para o gnaisse migmatítico do Complexo Belo Horizonte e mobilizado félsico

Figura 19: Diagrama isocrônico Rb-Sr em rocha total para o Gnaisse Belo Horizonte, Pedreira do Bairro Tupi

Figura 20: Diagrama concórdia para o Granito Santa Luzia

Figura 21: Diagrama isocrônico $\mathrm{Rb}$-Sr em rocha total para o Granito General Carneiro

Figura 22: (a) Curvas de ETR, normalizadas para condritos, para o Granito Morro da Pedra e o Granito Córrego do Brumado (b) Diagrama comparativo das curvas de ETR para os granitos Morro da Pedra e Córrego do Brumado e a curva média para o Gnaisse Belo Horizonte

Figura 23: Diagrama concórdia exibindo os dados obtidos para o Granito Morro da Pedra e Granito Córrego do Brumado

Figura 24: Diagrama isocrônico $\mathrm{Pb}-\mathrm{Pb}$ para o Granito Morro da Pedra

Mapa geológico da região meridional do Quadrilátero Ferrifero

Figura 33:

Modelo evolutivo para a região sul do Quadrilátero Ferrífero 


\section{INDICE DAS TABELAS}

Tabela 1: $\quad$ Composição em porção pouco alterada e totalmente alterada de um grăo de zircão 14

Tabela 2

Tabela 3:

Compilação de temperaturas de fechamento

Sumário de dados U-Pb de alta precisão para o Quadrilátero Ferrifero

Tabela 4

Composições químicas do Gnaisse Belo Horizonte, gnaisse migmatitico. mobilizado migmatitico e migmatito nebulítico

Tabela 5: Composição média do Gnaisse Belo Horizonte comparado a composição média de TTG arqueanos

Tabela 6: Composições químicas do Granito Santa Luzia, Granito General Carneiro, Granito Marzagăo e Granodiorito Ibirité

Tabela 7: Resultados analíticos U-Pb para o Gnaisse Belo Horizonte e Granito Santa Luzia (Complexo Belo Horizonte) Dados isotópicos $\mathrm{Rb}-\mathrm{Sr}$ em rocha total para o Gnaisse Belo Horizonte
Dados isotópicos $\mathrm{Rb}-\mathrm{Sr}$ em rocha total para o Granito General Carneiro

Tabela 8:

Tabela 9 Dados isotópicos K-Ar para o Complexo Belo Horizonte, Complexo Caeté e região leste do Quadrilátero Ferrifero

Tabela 11: Composições químicas do Granitos Morro da Pedra e Granito Córrego do Brumado

Tabela 12: Resultados analíticos U-Pb para os granitos Morro da Pedra e Córrego do Brumado

Tabela 13:

Razões isotópicas do $\mathrm{Pb}$ para o K-feldspato do Granito Morro da Pedra

Tabela 14: Composições químicas do Granito Salto do Paraopeba e do Batólito Alto Maranhão

Tabela 15: Resultados analíticos U-Pb, região meridional do Quadrilátero Ferrífero

Tabela 16: Razões isotópicas do $\mathrm{Pb}$ para os anfibólios do pegmatito de Salto do Paropeba

Tabela 21: Sumário dos dados geocronológicos obtidos neste estudo 


\section{RESUMO}

O Complexo Belo Horizonte representa um segmento de crosta arqueana, constituído principalmente por gnaisses tipo TTG, bandados e exibindo feições de migmatização (Gnaisse Belo Horizonte). Ocorrem encravadas nos gnaisses pequenas faixas de rochas supracrustais, de natureza vulcano-sedimentar (essencialmente vulcanitos máficos e sedimentos químicos), e corpos granitóides circunscritos. Estes granitóides apresentam aspecto homogêneo, foliação bem desenvolvida, tendo-se posicionado após o evento principal de migmatização do Gnaisse Belo Horizonte. Os dois corpos mais significativos são granitos cálcio-alcalinos de alto $\mathrm{K}$, designados Granito Santa Luzia e Granito General Carneiro.

Análises U-Pb em zircões de um mobilizado migmatítico definiram uma discórdia com intercepto superior em 2.860+14/-10 Ma, datando o evento de migmatização do Gnaisse Belo Horizonte. Titanitas do mobilizado e do gnaisse alinharam-se em outra discórdia, com intercepto inferior em $2.041 \pm 5 \mathrm{Ma}$. Esta idade foi interpretada como a do retrabalhamento (metamorfismo) do Evento Transamazônico impresso no Complexo Belo Horizonte.

O Granito Santa Luzia posicionou-se em $2.712+5 /-4 \mathrm{Ma}$ (idade U-Pb em zircão), sendo esta também a idade provável do Granito General Carneiro. Obteve-se uma isócrona Rb-Sr (rocha total) para o Gnaisse Belo Horizonte de 2.619 $165 \mathrm{Ma}$. Os eventos de granitogênese e de rejuvenescimento isotópico dos gnaisses mais antigos devem marcar os estágios finais de estabilização da crosta arqueana na região setentrional do Quadrilátero Ferrífero.

No extremo sudoeste do Quadrilátero Ferrífero um pequeno corpo granítico, o Granito Salto do Paraopeba, possui idade U-Pb, em zircão, de $2.612 \pm 5 \mathrm{Ma}$. Esta idade define, até o presente, o mais novo evento de granitogênese arqueana da região. Ainda no quadro da evolução arqueana, a análise U-Pb em rutilos de uma zona de cisalhamento mineralizada em ouro, cortanto o Grupo Nova Lima, forneceu resultado muito discordante mas com idade mínima de $2.580 \mathrm{Ma}$.

Esse conjundo de determinações geocronológicas, aliado a outros dados da bibliografia, permite delinear um quadro bastante acurado para a evolução da crosta arqueana. Informações adicionais são também fornecidas pelas datações de zircões detríticos, provenientes das unidades supracrustais proterozóicas do Quadrilátero Ferrifero. As mais antigas evidências da existência de núcleos continentais datam de ca. 3.200 Ma. Entretanto, o principal período de geração crustal parece ter ocorrido entre 3.000-2.900 Ma. A partir daí, o trend evolutivo registra um processo progressivo de amalgamação de blocos continentais, associado a intenso retrabalhamento da crosta primitiva e novos eventos de adição granitóide, além da deposição de sequências supracrustais do tipo greenstone belt (Supergrupo Rio das Velhas). Resultou desse 
processo a consolidação de extensa plataforma continental, provavelmente completada com a intrusão dos granitos arqueanos mais jovens, como o Granito Salto do Paraopeba.

A bacia de sedimentação do Supergrupo Minas implantou-se sobre essa plataforma, possivelmente ainda no final do Arqueano. Reforça a hipótese o fato de todos os zircões detríticos analisados para a Formação Moeda, unidade basal do Supergrupo Minas, serem mais antigos que 2.600 Ma. As outras unidades estudadas (Grupo Sabará, Grupo Itacolomi e Supergrupo Espinhaço) continham zircões gerados e/ou retrabalhados no Paleoproterozóico.

O pacote sedimentar do Supergrupo Minas registra a passagem de sedimentação plataformal (grupos Caraça, Itabira e Piracicaba) para sedimentação sin-orogênica, representada pelo Grupo Sabará, cuja idade máxima de deposição foi determinada em ca. 2.120 Ma.

A idade de intrusão do Batólito Alto Maranhão foi determinada por análises U-Pb em titanita e zircão, em $2.124 \pm 2 \mathrm{Ma}$. Este corpo, localizado a sul do Quadrilátero Ferrífero, possui composição tonalítica predominante e características geoquímicas indicativas de origem mantélica. Tal assertiva confirma-se pela idade-modelo Sm-Nd (TDM) na mesma faixa da idade $\mathrm{U}-\mathrm{Pb}$. Portanto, interpreta-se o Batólito Alto Maranhão como uma intrusão pré-colisional, ligada a consumo de crosta oceânica, marcando o estágio inicial do Evento Transamazônico.

As idades $\mathrm{U}-\mathrm{Pb}$ em titanitas do embasamento arqueano posicionam o ápice do overprint metamórfico transamazônico em 2.065-2.035 Ma. Este processo foi acompanhado pela intrusão de pequenos corpos graníticos na região setentrional do Quadrilátero Ferrifero, que são o Granito Córrego do Brumado (idade U-Pb em monazita de $2.045 \mathrm{Ma}$ ) e o Granito Morro da Pedra. Pegmatitos intrusivos na Formação Moeda, região de Salto do Paraopeba, apresentaram idade $\mathrm{Pb}-\mathrm{Pb}$ em anfibólio de $2.236 \pm 200 \mathrm{Ma}$.

Outras determinações geocronológicas, no âmbito do Complexo Belo Horizonte, incluem uma errócrona Rb-Sr para o Granito General Carneiro, de $1.740 \pm 53 \mathrm{Ma}$, e idades K-Ar em biotita, variando entre 1.800 e $1.000 \mathrm{Ma}$. As idades por volta de $1.800 \mathrm{Ma}$ poderiam registrar o resfriamento final do Evento Transamazônico. Já as idades mais novas refletem, provalmente, aberturas parciais do sistema isotópico K-Ar em eventos de baixa magnitude, ligados aos ciclos Espinhaço e Brasiliano.

Interpretação semelhante pode ser dada para as idades $\mathrm{K}-\mathrm{Ar}$ (biotita) obtidas para o Batólito Alto Maranhão, de $1.000 \pm 22$ e $730 \pm 25 \mathrm{Ma}$. Duas idades isocrônicas Rb-Sr, para este mesmo corpo, registram o rejuvenescimento isotópico brasiliano. $\mathrm{Na}$ mesma região, monazitas de veios quartzo-feldspáticos, encontrados na Falha do Engenho, possuem idade U-Pb de 596 Ma. A colocação desses veios. e os processos localizados de rejuvenescimento isotópico, foram interpretados como um reflexo da reativação de estruturas pré-existentes durante a deformação do Evento Brasiliano. O registro isotópico pouco expressivo desse evento, no Quadrilátero Ferrifero, é uma indicação de seu papel secundário na estruturação da região. 


\section{ABSTRACT}

The Belo Horizonte Complex represents an Archean crust segment principally composed of banded TTG-type gneisses, and exhibiting migmatization features (Belo Horizonte Gneiss). Small tracts of volcanosedimentary supracrustal rocks, essentially mafic volcanics and chemical sediments, and granitoid bodies occur enclosed by the gneisses. These granitoids are in general homogeneous, have well-developed foliation, and were emplaced after the main migmatization event that affected the Belo Horizonte Gneiss. The Santa Luzia and General Carneiro calcalkaline granites constitute the two most prominent granitic bodies.

The age of the Belo Horizonte Gneiss migmatization event is indicated by the $2860+14 /-$ $10 \mathrm{Ma}$ upper intercept of a discordia obtained by U-Pb analyses in zircons of a migmatitic mobilizate. Sphenes of this mobilizate and of the gneiss align along another discordia with a lower intercept at $2041 \pm 5 \mathrm{Ma}$. This is interpreted as the age of the Transamazonian tectonometamorphic event imprint-ed on the Belo Horizonte Complex.

The Santa Luzia Granite was emplaced at $2712+5 / 44 \mathrm{Ma}$ (U-Pb age in zircon), probably also corresponding to the age of the General Carneiro Granite. A Rb-Sr-whole-rock isochron indicates $2619 \pm 65 \mathrm{Ma}$ for the Belo Horizonte Gneiss. These ages define a granite genesis event and also an isotopic resetting of the older gneisses, possibly marking the final stages of stabilization of the Archean crust in the studied area.

The Salto do Paraopeba Granite occurs in the extreme southwest of the Quadrilátero Ferrifero, and has an $\mathrm{U}-\mathrm{Pb}$ age in zircon of $2612 \pm 5 \mathrm{Ma}$. At present, this age is interpreted as defining the youngest Archean granite genesis event. U-Pb analyses of rutiles from a goldmineralized shear zone, crosscutting the Nova Lima Group, yield a very discordant minimum age of $2580 \mathrm{Ma}$, also regarded as part of the Archean evolution of this region.

This set of geochronological determinations together with those already published allow the establishment of a fairly accurate framework for the Archean crust evolution. Additional information are also furnished by dating of detritic zircons, from Proterozoic supracrustal units of the Quadrilatero Ferrifero. The oldest evidences for the existence of continental nuclei axe dated at $c a 3200 \mathrm{Ma}$. However, the main period of crust generation seems to have happened between 3000 to $2900 \mathrm{Ma}$. Following this period, the evolutionary trend followed a progressive amalgamation of continental blocks, associated with intensive reworking of the primitive crust, renewed events of granitoid addition and deposition of the supracrustal greenstone belt Rio das Velhas Supergroup. As a result of this process, an extensive continental platform was 
consolidated. probably accompanied by the intrusion of younger Archean granites like the Salto do Paraopeba Granite.

The Minas Supergroup sedimentary basin was established on this platform possibly in the end of the Archean. This hypothesis is enhanced by detritic zircons consistently older than 2600 Ma from the Moeda Formation, basal unit of the Minas Supergroup. A number of the zircons from the other studied units, the Sabara and Itacolomi Groups, and the Espinhaço Supergroup, were crystallized and/or reworked during the Lower Proterozoic.

The Minas Supergroup sedimentary sequence records the change from platformal (Caraça, Itabira and Piracicaba Groups) to synorogenic sedimentation, the latter represented by the Sabara Group. The zircons of this Group define the maximum age of deposition ca $2120 \mathrm{Ma}$.

$\mathrm{U}-\mathrm{Pb}$ analyses in zircon and sphene determine the age of the intrusion of the Alto Maranhão Batholith at $2124 \pm 2 \mathrm{Ma}$. This granitic body is located to the south of the Quadrilatero Ferrifero, and has a predominantly tonalitic composition. A mantelic derivation is indicated by geochemical characteristics, and confirmed by a Sm-Nd model age (TDM) in the same range of ages obtained by $\mathrm{U}-\mathrm{Pb}$. Therefore, the Alto Maranhão Batholith is interpreted as a precollisional intrusion related to the consumption of the oceanic crust, marking the initial stage of the Transamazonian Event.

$\mathrm{U}-\mathrm{Pb}$ ages in sphenes from the Archean basement define the peak of the Transamazonian metamorphic overprint at 2065-2035 Ma. This process was accompanied by the intrusion of two small granitic bodies in the northern region of the Quadrilátero Ferrifero: the Córrego Brumado Granite (U-Pb age of $2045 \mathrm{Ma}$ in monazite) and the Morro da Pedra Granite. Pegmatites intrusive in the Moeda Formation in the region of Salto do Paraopeba have a $\mathrm{Pb}-\mathrm{Pb}$ age in amphibole of $2236 \pm 200 \mathrm{Ma}$.

Other geochronological determinations in the Belo Horizonte Complex include a $\mathrm{Rb}-\mathrm{Sr}$ errochron for the General Carneiro Granite at $1740 \pm 53 \mathrm{Ma}$, and $\mathrm{K}-\mathrm{Ar}$ ages in biotites varying between 1800 and $1000 \mathrm{Ma}$. The ages around $1800 \mathrm{Ma}$ might indicate the final cooling of the Transamazonian Event. The younger ages probably reflect partial opening of the K-Ar isotopic system during events of a lesser magnitude, related to the Espinhaço and Brasiliano cycles.

A similar interpretation arises from the $\mathrm{K}$-Ar ages of $1000 \pm 22$ and $730 \pm 25$ in biotite obtained for the Alto Maranhão Batholith. Two isochronic $\mathrm{Rb} \backsim \mathrm{Sr}$ ages obtained for the same batholith register the Brasiliano-cycle isotopic resetting. In the same region, quartz-feldspathic veins in the Engenho Fault yields an $\mathrm{U}-\mathrm{Pb}$ age in monazite of $596 \mathrm{Ma}$. The veins emplacement and the localized processes of isotopic resetting are interpreted as resulting from the reactivation of pre-existing structures during the Brasiliano Event deformation. The weak record of this Event in the Quadrilatero Ferrifero is indicative of its secondary role in the structuring of the region. 


\section{INTRODUÇÃO}

\subsection{APRESENTAÇÃO E OBJETIVOS DO TRABALHO}

O Quadrilátero Ferrifero é uma importante província metalogenética ( $\mathrm{Au}, \mathrm{Fe}, \mathrm{Mn}$ ), constituindo uma área clássica em termos de geologia pré-cambriana. $\mathrm{O}$ acervo de conhecimento geológico sobre o Quadrilátero Ferrífero é dos mais expressivos. Pode-se destacar, entre outros, os trabalhos de cartografia na escala 1:25.000, realizados entre os anos 1946/1965 por uma equipe de geólogos do United States Geological Survey e Departamento Nacional da Produção Mineral, sintetizados por Dorr (1969). Este acervo tem sido enriquecido, nos últimos anos, por diversas contribuições, com destaque para as de enfoque estrutural/geotectônico e metalogenético (e.g. Ladeira 1980, Marshak \& Alkmim 1989, Chemale Jr. et al. 1991, etc.).

A despeito do conhecimento acumulado, persistem ainda diversas questões relativas à evolução geológica do Quadrilátero Ferrífero. Estas, em grande parte, decorrem da dificuldade de definir, no tempo, os vários eventos magmáticos, sedimentares e tectono-metamórficos registrados na região. Como é a regra para os terrenos pré-cambrianos de evolução complexa e policíclica, as datações radiométricas passam a ser tanto mais imprescindiveis, quanto mais se aprofunda o conhecimento geológico.

Até recentemente, os dados geocronológicos disponíveis para o Quadrilátero Ferrífero eram, em sua quase totalidade, advindos dos métodos Rb-Sr e K-Ar (e.g. Cordani et al. 1980, Teixeira 1985). Em 1989, em trabalho realizado com a participação deste autor, obteve-se o primeiro acervo expressivo de idades $\mathrm{U}-\mathrm{Pb}$ de alta precisão (Machado et al. 1989a, 1992). Estes dados permitiram datar eventos de vulcanismo no Greenstone Belt Rio das Velhas, definiram idades de plutonismo granitóide no âmbito dos complexos granito-gnáissicos arqueanos, além de precisar a idade de eventos metamórficos proterozóicos. O conhecimento do quadro evolutivo arqueano foi, posteriormente, reforçado e ampliado pelas datações U-Pb realizadas por Machado \& Carneiro (1992) e Carneiro (1992).

O presente trabalho enriquece, consideravelmente, o acervo de dados geocronológicos U$\mathrm{Pb}$ para a região do Quadrilátero Ferrífero. São apresentados os resultados de 31 análises U-Pb 
em zircão. titanita e monazita. provenientes de corpos geológicos diversos. Parte destes dados permitiram a construção de cinco discórdias. Outras metodologias empregadas forneceram 110

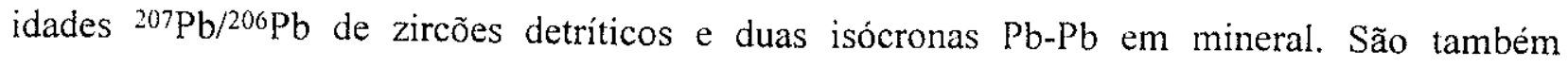
apresentadas uma idade modelo $(\mathrm{Tdm}) \mathrm{Sm}-\mathrm{Nd}$. quatro isócronas $\mathrm{Rb}-\mathrm{Sr}$ (rocha total) na escala de afloramento e quatro determinações $\mathrm{K}-\mathrm{Ar}$.

A utilização de métodos geocronológicos diversos permitiu a abordagem de amplo espectro de questões. Estas incluem a datação de eventos geradores de rocha, eventos de retrabalhamento crustal e reequilíbrio isotópico, delineação dos intervalos de tempo envolvidos na deposição das unidades sedimentares, dentre outras.

O propósito principal do presente estudo foi a elaboração de um quadro evolutivo que integrasse os diversos eventos geológicos dentro de uma coluna temporal. Este tema interessa ao entendimento da evolução do embasamento do Cráton do São Francisco como um todo, na medida em que novos dados, bastante precisos, são revelados quanto à duração dos ciclos tectônicos e à natureza dos fenômenos a eles associados.

\section{2. ÁREA INVESTIGADA}

O Quadrilátero Ferrífero localiza-se na região sudeste do Estado de Minas Gerais, centrado em torno das coordenadas $20^{\circ} 15^{\prime}$ de latitude sul e $43^{\circ} 30^{\prime}$ de longitude oeste (Figura 1). O espaço geográfico conhecido como Quadrilátero Ferrifero ocupa uma área de cerca de $7.000 \mathrm{~km}^{2}$, devendo seu nome ao arranjo definido por um conjunto de serras lineares com altitudes, em média, variando entre 1.100 e $1.600 \mathrm{~m}$. (Figura 2). Essas serras estão esculpidas em seqüências metassedimentares dobradas, especialmente o Supergrupo Minas, que encerra os imensos depósitos de minério de ferro da região. As áreas limítrofes ao Quadrilátero Ferrífero, de uma maneira geral, assentam-se sobre rochas gnáissicas, exibindo relevo menos acentuado com altitudes inferiores a $900 \mathrm{~m}$.

O Quadrilátero Ferrifero constitui um divisor de águas de duas importantes bacias hidrográficas. do Rio São Francisco e Rio Doce. As regiões central e ocidental são, respectivamente. drenadas pelo Rio das Velhas e Rio Paraopeba. ambos afluentes do Rio São Francisco. Os rios Piracicaba, Gualaxo e do Carmo drenam a região oriental, afluindo para o Rio Doce (Figura 2). 

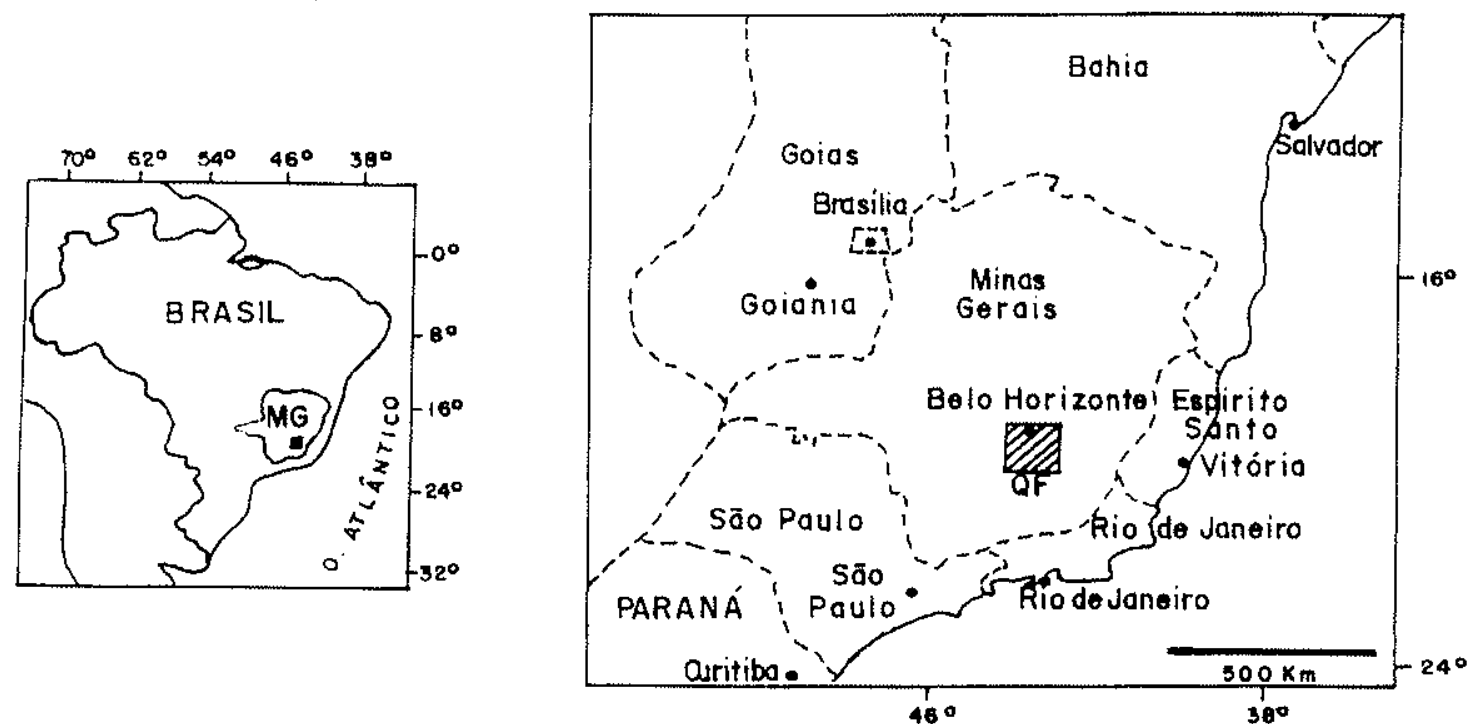

Figura 1: Localização da área investigada ( $Q F=$ Quadrilátero Ferrifero).

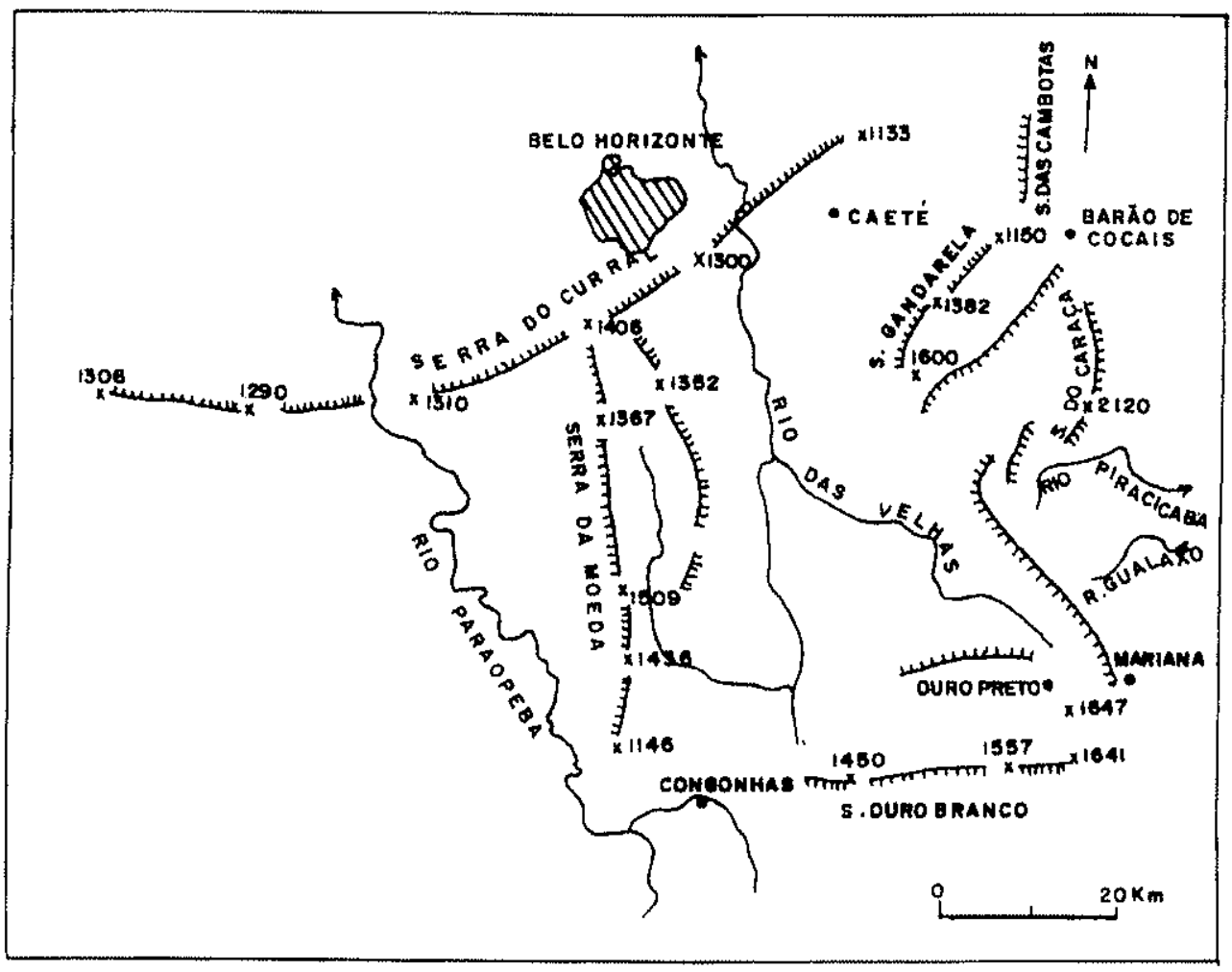

Figura 2: Principais feições fisiográficas (cristas de serra) e rede hidrográfica do Quadrilátero Ferrifero (modificado de Barbosa 1980). 
O limite geográfico setentrional do Quadrilátero Ferrifero é representado pela Serra do Curral. a norte da qual foi implantada a cidade de Belo Horizonte, inaugurada em 1897. A maioria das demais localidades da região remontam ao período colonial, originadas da "corrida do ouro" que teve lugar durante o final do século XVII e o século XVIII. Dentre estas, destaca-se a cidade de Ouro Preto, por preservar espressivo conjunto arquitetônico dessa época.

Uma malha viária densa e o grande número de pedreiras, minerações e exposições naturais favorecem a observação das várias unidades geológicas representadas no Quadrilátero Ferrifero. Entretanto, várias áreas são de acesso difícil. devido à topografía muito acidentada.

\subsection{METODOLOGIA DE TRABALHO}

A primeira etapa deste trabalho consistiu no levantamento das questões geológicas a serem abordadas pelos métodos geocronológicos, partindo-se do conhecimento prévio do autor e da literatura e cartografia geológicas existentes. Como resultado, foram definidas as áreas para detalhamento geológico e os alvos de amostragem para geocronologia. Cada uma dessas áreas e os corpos geológicos amostrados enquadravam-se num contexto geológico/tectônico específico, de forma que, de posse das datações, fosse possível uma abordagem global da evolução do Quadrilátero Ferrífero.

Os diferentes contextos geológicos e problemas estudados podem ser sistematizados da seguinte maneira:

\section{-Evolução dos terrenos granito-gnáissicos:}

Os estudos geocronológicos dos terrenos granito-gnáissicos da região do Quadrilátero Ferrífero têm-se ressentido da ausência de cartografia geológica interna. Foi selecionado para estudo aquele terreno situado ao longo do limite norte do Quadrilátero Ferrífero, designado Complexo Belo Horizonte (Ladeira \& Viveiros 1986), onde o grande número de pedreiras existentes permitia boas exposições de suas rochas.

Os trabalhos de campo levaram à individualização dos principais litotipos constituintes do complexo. posteriormente submetidos aos estudos geocronológicos. A partir dos dados U- $\mathrm{Pb}$ obtidos, nova amostragem para análises $\mathrm{Rb}-\mathrm{Sr}$ e $\mathrm{K}-\mathrm{Ar}$ foi realizada, visando a complementar as 
informações, além de possibilitar a confrontação dos resultados de métodos diferentes aplicados ao mesmo corpo geológico.

Embora um estudo petrogenético aprofundado fugisse ao escopo deste trabalho, foram realizadas análises químicas para o Complexo Belo Horizonte. Estas análises permitiram a caracterização geoquímica dos corpos datados, além de esboçar um quadro da evolução petrogenética.

\section{-Plutonitos granitóides e suas relações com unidades supracrustais:}

Foram selecionados, para datação, corpos granitóides intrusivos ou em contato tectônico com seqüências supracrustais. Objetivou-se, além do posicionamento desses corpos no quadro evolutivo regional, a obtenção de idades mínimas para as rochas supracrustais.

Dois pequenos plutonitos granitóides estudados provinham da região setentrional do Quadrilátero Ferrífero. O primeiro é intrusivo em uma pequena faixa de rochas vulcanosedimentares, encravada no Complexo Belo Horizonte, enquanto o outro posiciona-se nas rochas do Supergrupo Minas imediatamente adjacentes ao complexo.

No extremo sudoeste do Quadrilátero Ferrífero foram amostrados um granitóide em contato tectônico com a Formação Moeda (Supergrupo Minas) e pegmatitos intrusivos nesta mesma unidade.

Na região de Congonhas do Campo-Conselheiro Lafaiete, a sul do Quadrilátero Ferrifero, objetivou-se estabelecer a idade de um extenso corpo intrusivo em seqüência vulcano-sedimentar provavelmente correlata ao Grupo Nova Lima (Supergrupo Rio das Velhas).

As determinações geocronológicas para estes corpos granitóides envolveram, no conjunto, os métodos $\mathrm{U}-\mathrm{Pb}, \mathrm{Pb}-\mathrm{Pb}, \mathrm{Sm}-\mathrm{Nd}, \mathrm{Rb}-\mathrm{Sr}$ e K-Ar. Foram também efetuadas análises químicas visando a uma caracterização mais completa dos plutonitos estudados.

\section{-Idades de sedimentação:}

Esta questão foi investigada através da datação de zircões detríticos pelo método LP. ICPMS (laser-probe inductively coupled plasma mass spectrometry), que permite a obtenção de

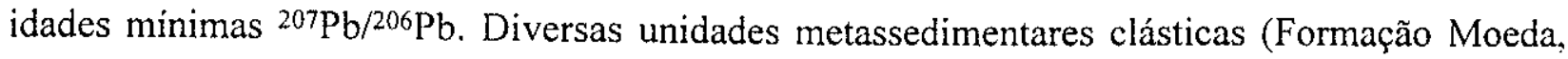
Supergrupo Espinhaço, Grupo Sabará e Grupo Itacolomi), em áreas diferentes do Quadrilátero Ferrifero. foram amostradas para esse tipo de investigação. O estudo propiciou o levantamento de informações quanto à idade das áreas-fonte e dos intervalos de sedimentação das unidades enfocadas. 


\section{-Eventos metalogenéticos:}

A abordagem deste tema retringiu-se a uma zona de cisalhamento aurífera da região nordeste do Quadrilátero Ferrífero, investigada por meio de datação U-Pb em rutilo, cuja gênese poderia estar associada ao processo de mineralização.

Os resultados das análises geocronológicas serão apresentados nos capítulos 4 a 7 , no contexto de cada um dos temas propostos acima. No capítulo final (Capítulo 8) apresenta-se a integração destes dados radiométricos, somados aos anteriormente disponiveis, dentro de uma proposta de evolução geológica do Quadrilátero Ferrifero durante o Pré-Cambriano.

A parte experimental do trabalho envolveu diferentes rotinas radiométricas em laboratórios distintos. No contexto das análises U-Pb, foram coletadas 21 amostras, cada uma contendo, em média, 10 a $15 \mathrm{~kg}$ de material. As amostras foram submetidas ao processo usual de separação mineral. As etapas finais do processo de análise, que incluem a seleção visual dos grãos minerais, abrasão, dissolução, extração química e espectrometria de massa, foram efetuadas pelo autor no Centre de Recherche en Géochimie Isotopique et en Géochronologie (GEOTOP) da Université du Québec à Montréal (Canadá). Esse trabalho realizou-se no período de outubro de 1991 a março de 1992, sob a orientação do Dr. Nuno Machado. Apenas 9 amostras possuíam minerais na qualidade e quantidades necessárias para a análise. Para duas amostras, cujos resultados $\mathrm{U}-\mathrm{Pb}$ foram inconclusivos, foram realizadas análises $\mathrm{Pb}-\mathrm{Pb}$ em mineral, a partir do material previamente preparado. Estas análises foram também efetuadas nos laboratórios do GEOTOP.

Análises de zircões detríticos pelo método LP-ICPMS foram feitas na Université de Montréal pelo Dr. Nuno Machado e Dr. Rui Feng, como parte de um projeto de colaboração científica. Apenas algumas das amostras preparadas foram analisadas, tanto pela virtual ausência de zircão como pelo não atendimento das especificações de tamanho e qualidade dos grãos para fins dos estudos previstos.

As análises $\mathrm{Sm}-\mathrm{Nd}$, $\mathrm{Rb}-\mathrm{Sr}$ e $\mathrm{K}-\mathrm{Ar}$ foram efetuadas no Centro de Pesquisas Geocronológicas (CPGeo) da Universidade de São Paulo. No caso das análises Rb-Sr, foram coletadas várias amostras por afloramento, com peso de 1 a $2 \mathrm{~kg}$ cada, sem alteração visível. $\mathrm{O}$ contexto da amostra no afloramento e a presença de outras fases magmáticas foram anotadas para cada amostra. A preparação das amostras e análises seguiram a rotina do CPGeo. As isócronas $\mathrm{Rb}-\mathrm{Sr}$ foram construídas a partir de pontos de um único afloramento (entre 4 e 9 pontos).

Os resultados geoquímicos foram obtidos nos laboratórios do GEOLAB/GEOSOL e do Centro de Pesquisa Professor Manuel Teixeira da Costa (CPMTC) do Instituto de Geociências. Universidade Federal de Minas Gerais. 


\subsection{A ESCALA DE TEMPO DO PRÉ-CAMBRIANO E OS CICLOS TECTÔNICOS DA PLATAFORMA SUL-AMERICANA}

A nova escala de tempo para o Pré-Cambriano, aprovada pela International Union of Geological Sciences (IUGS), encontra-se apresentada por Fuck (1991a, 1991b). O limite entre os éons Arqueano e Proterozóico foi mantido em 2.500 Ma. O Arqueano foi dividido nos seguintes períodos: Eoarqueano ( $\geq 3.600 \mathrm{Ma}$ ), Paleoarqueano (3.600-3.200 Ma), Mesoarqueano (3.200$2.800 \mathrm{Ma})$ e Neoarqueano (2.800-2.500 Ma). Para o Proterozóico adotaram-se os períodos listados a seguir: Paleoproterozóico (2.500-1.600 Ma), Mesoproterozóico (1.600-1.000 Ma) e Neoproterozóico (1.000 Ma-base do Cambriano).

O início do Mesoproterozóico é caracterizado pela expansão de coberturas plataformais ou pela formação de novas coberturas sobre embasamento recém-cratonizado, a partir de 1.600 Ma, em continentes diversos (Fuck 1991a). Na Plataforma Sul-Americana, eventos desta natureza ocorreram em época mais antiga, o que tem levado à adoção, por vários autores (e.g. Almeida \& Hasui 1984, Brito Neves et al. 1990), de um limite de tempo Paleoproterozóico/Mesoproterozóico diferente daquele proposto na coluna da IUGS. Embora se reconheça a necessidade e importância de uma coluna de tempo global, a atribuição do Ciclo Espinhaço, iniciado em torno de $1.750 \mathrm{Ma}$, ao Mesoproterozóico, encontra-se entranhada na geologia brasileira e será mantida no presente trabalho.

Diversos ciclos e eventos tectônicos são reconhecidos na evolução pré-cambriana da Plataforma Sul-Americana. Os termos ciclo e evento são utilizados, no presente trabalho, segundo a conceituação expressa por Almeida \& Hasui (1984): "Os eventos termotectônicos correspondem a etapas de processos geológicos de maior importância, os ciclos tectônicos, que, além de metamorfismo, dobramentos e plutonismo, envolvem sedimentação, vulcanismo e outras manifestações tectônicas". Os eventos representam as fases orogênicas de um ciclo. Considerando-se o contexto geológico regional, onde se encaixa a área estudada, quatro ciclos tectônicos encontram-se caracterizados, entre o Neoarqueano e o Neoproterozóico. O primeiro deles é o Ciclo Jequié, entre 2.800 e $2.550 \mathrm{Ma}$ (Brito Neves et al. 1990). Segundo Almeida \& Hasui (1984), o Ciclo Transamazônico estendeu-se pelo intervalo $>2.500-1.800 \mathrm{Ma}$, enquanto a duração do principal evento tectônico correspondente (Evento Transamazônico) foi de 2.100. 1.800 Ma (ou 2.200-1.800 Ma, de acordo com Brito Neves et al. 1990). A caracterização dos processos geológicos e intervalos temporais relativos aos ciclos Espinhaço e Brasiliano é um assunto polêmico, cuja discussão fugiria ao escopo desta seção. Os pontos consensuais são o limite superior do Ciclo Espinhaço, definido pelo início da sedimentação do Supergrupo 
Espinhaço (ca. $1.750 \mathrm{Ma}$ ) e o posicionamento das principais fases orogênicas do Ciclo Brasiliano, entre 750-500 Ma (Brito Neves et al. 1990).

\subsection{AGRADECIMENTOS}

Inicialmente, o autor deseja manifestar seu profundo reconhecimento ao inestimável apoio, tanto laboratorial como científico, recebidos por parte de seu orientador, Prof. Dr. Wilson Teixeira (IG-USP). Igualmente, este trabalho não teria sido possível sem a participação do Dr. Nuno Machado (GEOTOP-UQAM), que propiciou a obtenção da parte essencial dos dados geocronológicos, dedicando inúmeras horas aos trabalhos de laboratório e à discussão dos resultados obtidos.

Todas as etapas deste trabalho envolveram alguma forma de colaboração de indivíduos ou instituições que tornaram possível sua concretização. Uma lista completa seria por demais extensa, mas o autor gostaria de manifestar a todos seus sinceros agradecimentos.

As etapas de campo e a preparação de grande parte das amostras contou com a colaboração das seguintes empresas ou instituições: SMM (Sociedade Mineira de Mineração), UNAMGEM, Departamento de Engenharia de Minas da UFMG, CDTN (Centro de Desenvolvimento da Tecnologia Nuclear) e COMIG SA (Companhia Mineradora de Minas Gerais). Nossos especiais agradecimentos aos geólogos Milton G. Bueno do Prado e Sérgio M. Pereira (UNAMGEM) e Tágides Ferreira Jr. (SMM). As informações prestadas no campo pelo Prof. Luiz A. R. Seixas (UFRRJ) foram essenciais a uma parte deste trabalho.

Em relação ao trabalho laboratorial no GEOTOP-Montreal, registramos nossa gratidão ao apoio institucional, na pessoa do Dr. Clement Gariépy. Pelo auxílio nas etapas analíticas e discussão dos resultados agradecemos a Jean Carignan, Bill Davis, Dave Scott e Francine Robert. Para Jack Kugelmass, Gema Olivo e Alice Chassagne, merci beaucoup!

Agradecemos a todo o corpo técnico do CPGeo-USP pelo apoio analítico isotópico e facilidades colocadas à disposição do autor para o presente trabalho.

Ao corpo técnico do CPMTC-UFMG, agradecemos a realização de parte das análises químicas. 
No transcorrer do trabalho, o autor beneficiou-se das sugestões. críticas e informações de diversos pesquisadores. Especialmente, agradecemos aos professores João Henrique Grossi Sad. Antônio Carlos Pedrosa Soares, Antônio Wilson Romano, Carlos Alberto Rosière e Luiz Guilherme Knauer do IGC-UFMG; Benjamim Bley de Brito Neves e Marly Babinski do IGUSP, Maurício Antônio Carneiro da UFOP e ao geólogo Osvaldo A. Belo de Oliveira da DOCEGEO. Ao Prof. Ricardo Diniz da Costa, nossa gratidão pela ajuda nos tortuosos caminhos da informática.

O Prof. Edésio Teixeira de Carvalho (IGC-UFMG) teve a gentileza de rever o texto final, contribuindo com seu profundo conhecimento da língua portuguesa. Agradecemos também à Profa. Lydia Lobato (IGC-UFMG) pelo auxílio na redação do abstract.

Este trabalho contou com finaciamento da FAPESP (processo $n^{\circ}$ 91/0434-0) e FAPEMIG (processo $n^{\circ} \mathrm{CEX}-24 / 91$ ). $\mathrm{O}$ autor beneficiou-se de bolsa de doutorado do programa PICD-Capes e bolsa doutorado-sanduíche do CNPq. 


\section{MÉTODOS ANALÍTICOS EM GEOCRONOLOGIA}

\subsection{GEOCRONOLOGIA U-Pb DE ALTA PRECISÃO}

A utilização de minerais portadores de U em determinações geocronológicas é determinada por vários critérios, como a retentividade para $\mathrm{U}$ e $\mathrm{Pb}$, conteúdo em $\mathrm{Pb}$ comum inicial e ocorrência do mineral em diferentes tipos de rochas. O zircão é o mais empregado, mas a lista inclui outros minerais como titanita, monazita, baddeleyita, rutilo, apatita, uraninita, granada, etc. (e.g. Heaman \& Parrish 1991).

A geocronologia U.Pb experimentou notável evolução nas últimas décadas, a partir das novas técnicas de dissolução do zircão e extração do $U$ e $\mathrm{Pb}$, aliadas à redução dos índices de contaminação em $\mathrm{Pb}$ comum, desenvolvidas por Krogh (1973). Isto tornou possível a análise de frações de zircão muito pequenas, ou mesmo de grãos individuais. Outro desenvolvimento fundamental adveio das metodologias de seleção e abrasão dos grãos minerais (Krogh 1982a, 1982b), que resultaram em análises muito concordantes (em relação à curva concórdia). Este conjunto de procedimentos deu origem à geocronologia U-Pb de alta precisão. Erros da ordem de 0,3 a $0,1 \%$, com um nível de confiabilidade de $95 \%(2 \sigma)$, têm sido, corriqueiramente, obtidos na datação de rochas arqueanas (e.g. Nunes \& Thurston 1980, Davis et al. 1982).

A seleção criteriosa dos grãos é o primeiro passo para a obtenção de idades muito precisas. Os grãos de zircão devem ser limpos, não fraturados e, preferencialmente, não magnéticos. Krogh (1982a) constatou que os grãos menos magnéticos são, normalmente, mais pobres em U e fornecem análises mais concordantes. Nos cristais muito ricos em $U$ os danos à rede cristalina. causados pela radiação, aumentam a perda de $\mathrm{Pb}$.

Os zircões selecionados devem ser divididos em populações segundo cuidadosa classificação tipológica. Esta classificação é feita a partir de critérios de tamanho, forma, cor, presença ou não de núcleo e sobrecrescimento(s), dentre outros. Em consequência, cada fração para análise deverá conter apenas grãos cuja semelhança de propriedades seja a mais indicativa possível do caráter cogenético. 
A abrasão dos grãos, com conseqüente remoção de sua porção externa. tende a minimizar a perda de $\mathrm{Pb}$ (difusão do $\mathrm{Pb}$ para fora do grão). A maior parte desta perda de $\mathrm{Pb}$ dá-se pela abertura do sistema nas zonas mais externas do zircão. como demonstrado por Krogh (1982b). Desta forma, análises de grãos submetidos à abrasão tendem a posicionar-se próximo ou, mesmo, sobre a curva concórdia, aumentando a precisão das idades obtidas.

$\mathrm{O}$ refinamento da qualidade analítica e os baixos indices de contaminação em $\mathrm{Pb}$ comum (brancos analíticos para o $\mathrm{Pb}$ inferiores a 50pg; e.g. Heaman \& Parrish 1991) permitiram a análise de frações compostas por grãos individuais de zircão. Esta possibilidade é de grande importância para o estudo de rochas com população de zircão muito heterogênea, que muitas vezes incluem grãos herdados.

A descrição da metodologia básica adotada no GEOTOP, onde foram realizadas as datações U-Pb do presente trabalho, é apresentada nos ítens seguintes.

\subsubsection{Preparação das amostras}

O peso das amostras variava entre 6 e $18 \mathrm{~kg}$. A preparação destas segue o procedimento usual de britagem, moagem e concentração em mesa vibratória. Esta etapa foi realizada no laboratório do Departamento de Engenharia de Minas da UFMG. Como não havia disponibilidade para uso da mesa vibratória, a concentração foi feita em bateia. Este método mostrou-se rápido e muito eficiente para a concentração da fração pesada das amostras. Deve-se ressaltar a necessidade de cuidados extremos na limpeza dos equipamentos e materiais utilizados (e.g. britador, moinho, recipientes, etc.), de forma a eliminar a possibilidade de contaminação por grãos minerais de amostras preparadas anteriormente.

A amostra concentrada na bateia é peneirada, separando-se a fração retida na peneira de 65 mesh. Esta fração é então concentrada em bromofórmio e submetida à primeira etapa de separação magnética, conhecida como "Frantz Inicial". Nesta, o aparelho (separador magnético Frantz) é mantido com um ângulo de inclinação lateral constante a $10^{\circ}$, o campo magnético variando de 0,25 a 1,8A. A fração não magnética final sofre nova separação em líquido pesado,o iodeto de metileno $(d=3,25)$, basicamente para separar as apatitas na fração leve. A fração pesada passa novamente pelo separador magnético, desta vez regulado no campo magnético máximo (1.8A) e com ângulos de inclinação variando de $5^{\circ}$ a $0^{\circ}$. Esta operação é designada "Frantz Final". 
As etapas de separação magnética permitem, inicialmente. a rápida determinação da presença dos minerais de interesse. A titanita concentra-se, preferencialmente, na fração magnética de 1,0A, enquanto a monazita é encontrada nas frações de 1,0 a 1,8A do "Frantz Inicial". Rutilo concentra-se nas primeiras frações do "Frantz Final". Em relação ao zircão, os grãos de melhor qualidade são aqueles das frações menos magnéticas, ou não magnética, do "Frantz Final".

A seleção dos grãos para análise é feita em lupa binocular. No presente trabalho, as frações de zircão consistiam de grãos individuais a populações com até 20 grãos. As frações de titanita, em média, continham 40 grãos. Os grãos selecionados foram então submetidos à abrasão no aparelho descrito por Krogh (1982b), utilizando-se pirita como abrasivo. A abrasão de zircão tem-se mostrado extremamente efetiva na diminuição da discordância das análises, ou seja, os pontos analisados tendem a cair muito próximo da curva concórdia. Entretanto, sua utilização para outros minerais, como titanita e monazita, nem sempre resulta em análises mais concordantes, como foi constatado neste trabalho. O tempo de abrasão das frações de zircão depende das dimensões e dureza dos grãos. As diversas frações analisadas sofreram abrasão por períodos que variaram de 4 a $50 \mathrm{~h}$, em geral a pressões de 3 psi. Para titanita e monazita utilizaram-se pressões mais baixas, 2 psi, por periodos, em geral, inferiores a $2 \mathrm{~h}$.

\subsubsection{Lavagem, pesagem, dissolução dos grãos minerais e extração do $\mathrm{U}$ e $\mathrm{Pb}$}

Para esta etapa utiliza-se o laboratório limpo, equipado com filtros, onde é exigido o uso de trajes apropriados. Os procedimentos químicos são realizados em capelas de pressão positiva, igualmente equipadas com filtros.

Após a seleção e abrasão, as frações minerais são transferidas para pequenos béqueres $(10 \mathrm{ml})$ e lavadas com $\mathrm{HNO}_{3}$, água bidestilada e acetona. São então colocadas em pequenas "canoas" de papel alumínio e pesadas em balança analítica de precisão. Dámse, então, a transferência para os recipientes de dissolução, juntamente com a adição de spike misto ${ }^{205} \mathrm{~Pb}$ ${ }^{235}$ U (Krogh \& Davis 1975).

As técnicas básicas de dissolução dos minerais são as descritas por Krogh (1973). Zircão, titanita e rutilo são dissolvidos com $\mathrm{HF}+\mathrm{HNO}_{3}$; monazita com $\mathrm{HCl}$. A dissolução processa-se em cápsulas de teflon. seladas em jaquetas de aço, colocadas em estufa a uma temperatura de $220 \mathrm{C}$, por um tempo médio de $120 \mathrm{~h}$. Para a titanita, as condições de dissolução são menos severas. Utilizam-se béqueres Savilex Teflon, com tampa, sobre uma chapa quente. O tempo de dissolução é consideravelmente menor, em torno de $12 \mathrm{~h}$. 
A separação química do $\mathrm{U}$ e $\mathrm{Pb}$ é feita através de colunas de resina de troca iônica. Para o zircão, segue-se a técnica de Krogh (1973), modificada para os demais minerais (titanita e monazita) por Corfu \& Stott (1986). As soluções (amostras) são adicionadas às colunas, previamente preparadas com $\mathrm{HCl} 3,1 \mathrm{~N}$, seguindo-se sucessivas operações de lavagem com este mesmo ácido e água bidestilada. No caso do zircão, a lixiviação final do U é feita com $\mathrm{HCl} 6 \mathrm{~N}$ e do $\mathrm{Pb}$ com água bidestilada. A técnica de Corfu \& Stott (1986) para titanita e monazita utiliza $\mathrm{HBr} 1 \mathrm{~N}$ na lixiviação final do $\mathrm{U}$.

\subsubsection{Espectrometria de massa e resultados analíticos}

$\mathrm{O} U$ e $\mathrm{Pb}$ são depositados em monofilamento de $\mathrm{Re}$ com sílica-gel e $\mathrm{H}_{3} \mathrm{PO}_{4} 0,75 \mathrm{~N}$, segundo a técnica de Cameron et al. (1969). As razões isotópicas foram medidas com um espectrômetro de massa VG-354, a $1.400-1.500{ }^{\circ} \mathrm{C}$ para o $\mathrm{Pb}$ e $1.500-1.600^{\circ} \mathrm{C}$ para o $\mathrm{U}$.

Os fatores de correção para o fracionamento de massa de $\mathrm{Pb}$ são de $0,09 \%$.u.m.a. ${ }^{-1}$ no caso de coletor Faraday e 0,24\%.u.m.a. ${ }^{-1}$ para coletor Daly.

Os valores máximos do branco analítico, para a maioria das análises de zircão, foi de $15 \mathrm{pg}$ para $\mathrm{Pb}$ e 5pg para $\mathrm{U}$. Três análises apresentaram valores mais elevados para o $\mathrm{Pb}$, entre $37 \mathrm{e}$ $104 \mathrm{pg}$. Nas análises de titanita, monazita e rutilo os brancos, respectivamente para $\mathrm{Pb}$ e $\mathrm{U}$, foram de 25 e $5 \mathrm{pg}$. Na correção do $\mathrm{Pb}$ comum do branco utilizou-se a seguinte composição isotópica:

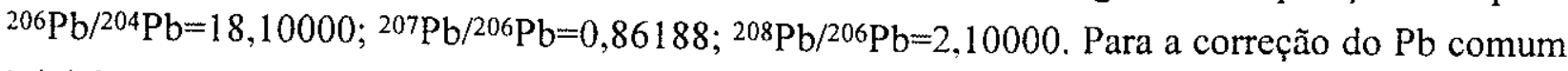
inicial, ou seja, o $\mathrm{Pb}$ comum total subtraído do $\mathrm{Pb}$ do branco, a composição isotópica é estimada a partir do modelo de Stacey \& Kramers (1975).

As regressões lineares e determinações de interceptos foram calculadas segundo o modelo de Davis (1982). Todos os erros nas idades, apresentados neste trabalho, estão no nível de confiabilidade $2 \sigma(95 \%)$ As constantes de decaimento do U são as recomendadas pelo IUGS (Steiger \& Jager 1977).

\subsubsection{Considerações sobre o processo de alteração dos zircões}

Quase todas as amostras estudadas apresentavam, em maior ou menor grau, alteração nos grãos de zircão. Esta alteração manifestava-se pelo aspecto branco leitoso dos grãos. Os zircões 
alterados são bastante magnéticos. frequentemente ficando retidos nas frações do "Frantz Inicial". Das amostras submetidas ao processo de separação mineral. 12 tiveram que ser descartadas devido à alteração quase total dos zircões.

Visando ao entendimento desse fenômeno da alteração. foram realizadas diversas análises em microscópio eletrônico de varredura, especialmente em porções alteradas e não alteradas de um mesmo grão. Todas as análises mostram acentuado enriquecimento aparente em $\mathrm{Fe}$ nas porções alteradas, mais subordinadamente em $\mathrm{Ca}$. O enriquecimento em $\mathrm{Fe}$ era esperado, devido ao comportamento muito magnético dos zircões. Enriquecimento aparente em $\mathrm{Al}$ e $\mathrm{Mg}$ foi registrado em uma das análises e em Ti em outra. A análise semi-quantitativa de um dos grãos é apresentada na tabela 1 , onde o acentuado enriquecimento em Fe e Al. na porção alterada, fica evidenciado, bem como possível perda de $\mathrm{Zr}$.

Tabela 1: Composição em porção pouco alterada (1) e totalmente alterada (2) de um grão de zircão (\% em peso). Análise semi-quantitativa em microscópio eletrônico de varredura.

\begin{tabular}{|c|c|c|}
\hline Óxido & $(1)$ & $(2)$ \\
\hline $\mathrm{SiO}_{2}$ & 26,02 & 24,89 \\
$\mathrm{ZrO}_{2}$ & 72,20 & 27,17 \\
$\mathrm{FeO}$ & 0,44 & 30,56 \\
$\mathrm{Al}_{2} \mathrm{O}_{3}$ & 0,00 & 12,11 \\
$\mathrm{MgO}$ & 0,00 & 3,57 \\
$\mathrm{CaO}$ & 1,34 & 1,69 \\
\hline
\end{tabular}

A alteração dos zircões é generalizada nas rochas arqueanas do Quadrilátero Ferrífero, fato também descrito por Carneiro (1992). Por outro lado, os zircões de parte das rochas proterozóicas exibiam pouca ou nenhuma alteração. Nos zircões mais antigos, a percolação de fluidos, promovendo a difusão do Fe e outros elementos, deve ser facilitada por uma rede cristalina mais danificada pela radiação. Esses elementos, por sua vez, seriam liberados nas reações de alteração de minerais como plagioclásio e biotita. Tais reações são muito acentuadas nas rochas arqueanas estudadas. 


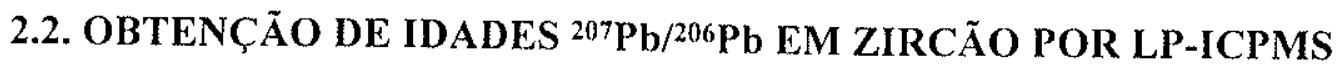 (LASERPROBE - INDUCTIVELY COUPLED PLASMA MASS SPECTROMETRY)}

O uso de um laser probe acoplado a um ICPMS, para análise de razões isotópicas de elementos sólidos, é uma técnica muito recente (Arrowsmith 1987, Hager 1989). Feng et al. (1993) apresentam os resultados da aplicação desta técnica na obtenção de idades ${ }^{207} \mathrm{~Pb} / 206 \mathrm{~Pb}$ de grãos individuais de zircão, juntamente com detalhada descrição do método.

Os grãos de zircão, selecionados dentre os de melhor qualidade, livres de inclusões e fraturas, são montados em resina epoxy e polidos. Cada grão é irradiado por um feixe de laser, utilizando-se um aparelho VG Laser Probe, acoplado ao ICPMS da marca VG PQII+ICP. O laser vaporiza a área do grão atingida, sendo o material ionizado no plasma e as razões isotópicas analisadas no espectrômetro de massa.

Uma limitação do método refere-se ao diâmetro do feixe de laser. Este varia, em função das propriedades do zircão (especialmente a cor), entre 30 e $60 \mu \mathrm{m}$. Por esta razão, apenas grãos relativamente grandes, com diâmetro maior que $75 \mu \mathrm{m}$ podem ser analisados. Outro fator limitante é o fato de o método fornecer apenas idades mínimas $\left({ }^{207} \mathrm{~Pb} / 206 \mathrm{~Pb}\right)$.

Em comparação com o método U-Pb tradicional, o LP-ICPMS permite a obtenção muito mais rápida de dados, na medida em que elimina etapas demoradas e trabalhosas, como a abrasão, lavagem dos grãos, dissolução e extração química. Por outro lado, a precisão das idades varia entre $<1$ e $5 \%$, muito inferior à que se obtém com o método U-Pb convencional $(0,1-0,3 \%)$, além de serem idades mínimas. A despeito destas limitações, a possibilidade de obter grande volume de dados, em tempo relativamente curto, torna o método bastante apropriado para o estudo de populações de zircões detríticos, onde a alta precisão é menos importante que o reconhecimento de grupos de idades.

No presente trabalho, essa técnica foi empregada na datação de populações de zircões detríticos, em cinco amostras de diferentes unidades metassedimentares do Quadrilátero Ferrifero. Os grãos, em geral, não apresentavam alteração, ao contrário do ocorrido nas rochas gnáissicas e granitóides. O número de zircões analisados, para cada amostra, variou em função do número de grãos com as dimensões e qualidade requeridas pelo método analítico. Os valores obtidos são apresentados com nível de confiabilidade $1 \sigma$. 


\subsection{MÉTODO ISOCRÔNICO Pb-Pb EM MINERAL}

A técnica consiste na lixiviação por ácido de concentrados minerais (Deloule et al. 1989), obtendo-se análises isotópicas do $\mathrm{Pb}$ do lixiviado, resíduo e amostra total. As frações minerais analisadas por este método, reportadas recentemente na bibliografia, incluem sulfetos, óxidos, carbonatos, K-feldspato, plagioclásio e anfibólio (Deloule et al. 1989, Carignan et al. 1993a e 1993b).

Na lixiviação são utilizados os ácidos $\mathrm{HCl}$, HBr e HF. O tratamento visa à dissolução e extração do $\mathrm{Pb}$ radiogênico contido nas porções da rede cristalina danificadas pela desintegração radioativa dos átomos de $\mathrm{U}$. Este $\mathrm{Pb}$ radiogênico, durante a lixiviação, é mais facilmente dissolvido que o $\mathrm{Pb}$ inicial comum incorporado durante a cristalização. Outra possível fonte de $\mathrm{Pb}$ radiogênico são microinclusões ricas em $\mathrm{U}$ como, por exemplo, apatita em sulfetos (Deloule et al. 1989).

A concentração de $\mathrm{Pb}$ radiogênico, naqueles setores danificados da rede cristalina, resulta também de uma maior concentração inicial de átomos de U nesses mesmos setores. Desta forma, a análise isotópica de lixiviado e residuo equivale à análise de partes do mineral com diferentes razões iniciais ${ }^{238} \mathrm{U} / 204 \mathrm{~Pb}$. Resulta, então, a dispersão das razões ${ }^{206} \mathrm{~Pb} / 204 \mathrm{~Pb}$, o que permite a construção de uma isócrona interna. $\mathrm{O}$ lixiviado, por concentrar o $\mathrm{Pb}$ radiogênico, apresenta as maiores razões $206 \mathrm{~Pb} / 204 \mathrm{~Pb}$.

No presente estudo foram separadas frações de anfibólio e K-feldspato de duas amostras. As frações continham de 6 a $15 \mathrm{mg}$ de material e o procedimento analítico seguiu os seguintes passos: lavagem com $\mathrm{HNO}_{3}$ e água destilada, lavagem com $\mathrm{HCl}$ 6N aquecido por $30 \mathrm{~min}$, lavagem com água destilada, secagem e pulverização. A lixiviação faz-se por adição de uma solução diluída de $\mathrm{HF}+\mathrm{HBr}$ (ou $\mathrm{HCl} 6 \mathrm{~N}$ ), aquecendo-se por 30 a $45 \mathrm{~min}$. A solução é extraída, constituindo o lixiviado. Resíduo e amostra total são dissolvidos em HF.

A separação do $\mathrm{Pb}$, por técnica de troca iônica, segue os procedimentos descritos por Manhés (1980). As análises isotópicas foram realizadas em espectrômetro de massa VG-354 equipado com coletor Faraday. As composições isotópicas foram corrigidas para 0 fracionamento de massa utilizando-se o fator $0,09 \%$ u.m.a. ${ }^{-1}$.

As idades isocrônicas $\mathrm{Pb}$ - $\mathrm{Pb}$ foram determinadas pelo método de regressão de Ludwig (1983. 1990). Os erros nas idades obtidas mostram precisão de $95 \%$. 


\subsection{MÉTODO Sm-Nd}

As análises Sm-Nd, em rocha total, foram efetuadas no Centro de Pesquisas Geocronológicas (CPGeo). Utilizou-se a técnica das duas colunas; a separação destes elementos terras-raras é feita, inicialmente, em uma coluna de resina de troca iônica, seguida por uma coluna do tipo HDEHP-coated teflon powder column. As razões isotópicas foram medidas em espectrômetro de massa VG-354.

Uma descrição detalhada da metodologia analítica para determinações Sm-Nd, adotada no CPGeo, pode ser encontrada em Sato et al. (1994).

\subsection{MÉTODOS Rb-Sr E K-Ar}

$O$ uso destas metodologias teve um caráter subordinado no presente estudo. A região já contava com um acervo de datações Rb-Sr e K-Ar, resultando daí a ênfase em outros métodos de diferente valor interpretativo. Estas diferenças podem ser pronunciadas, por exemplo, ao se aplicar os métodos U-Pb e Rb-Sr para rochas dos complexos granito-gnássicos do Quadrilátero Ferrífero. Enquanto o sistema U.Pb preserva a "memória" dos eventos magmáticos e/ou eventos metamórficos principais, o sistema $\mathrm{Rb}-\mathrm{Sr}$ pode registrar eventos de pertubação isotópica muito posteriores, de difícil interpretação no quadro evolutivo regional (e.g. Carneiro 1992, Carneiro \& Teixeira 1992).

As metodologias para as datações Rb-Sr e K-Ar seguem o procedimento padrão do Centro de Pesquisas Geocronológicas (CPGeo), o qual encontra-se descrito em diversas publicações (e.g. Teixeira 1985, Cordani et al. 1985, Sato 1986, Kawashita et al. 1990). As isócronas Rb-Sr foram calculadas segundo o método de Williamson (1968), apresentando nível de confiabilidade $1 \sigma$. 


\subsection{CONSIDERAÇÕES SOBRE AS TEMPERATURAS DE FECHAMENTO DE SISTEMAS ISOTÓPICOS}

O conceito de temperatura de fechamento $\left(\mathrm{T}_{\mathrm{f}}\right.$ ), formalizado por Dodson (1973), tem grande importância na interpretação de dados radiométricos. Uma idade de mineral, obtida a partir de um sistema isotópico qualquer, registra a época em que cessa a difusão do isótopo radiogênico. $O$ valor da $T_{f}$ expressa a temperatura na qual o mineral adquire retentividade para o isótopo radiogênico. Heaman \& Parrish (1991) apresentam uma compilação de valores de $\mathrm{T}_{\mathrm{f}}$, parcialmente reproduzida na tabela 2 . No caso do sistema $U-P b$, todas as $T_{f}$ foram estimadas a partir de exemplos naturais, com pouco controle dos diversos parâmetros envolvidos (Heaman \& Parrish 1991). A $\mathrm{T}_{\mathrm{f}}$ é influenciada pela taxa de resfriamento, tamanho e forma dos grãos minerais (Dodson 1973, Corfu et al. 1985). Portanto, as estimativas de valores podem variar segundo o autor, por exemplo, como constado para a titanita (Tabela 2).

Tabela 2: Compilação de temperaturas de fechamento (extraido de Heaman \& Parrish 1991).

\begin{tabular}{|l|c|l|}
\hline MINERAL & $\mathrm{T}_{\mathrm{f}}$ & \multicolumn{1}{|c|}{ REFERÉNCIAS* } \\
\hline \hline U-Pb & & \\
zircão & $>800^{\circ} \mathrm{C}$ & Heaman \& Parrish (1991) \\
monazita & $700^{\circ} \mathrm{C}$ & Copeland et al. (1988) \\
titanita & $600^{\circ} \mathrm{C}$ & Tucker et al. (1987), Heaman \& Parrish (1991) \\
& $500^{\circ} \mathrm{C}$ & Mattinson (1978)** \\
rutilo & $400^{\circ} \mathrm{C}$ & Mezger et al. (1989) \\
\hline K-Ar, Ar-Ar & & \\
hornblenda & $530 \pm 40^{\circ} \mathrm{C}$ & Harrison (1981), MacDougall \& Harrison (1988) \\
biotita & $280 \pm 40^{\circ} \mathrm{C}$ & Harrison et al. (1985) \\
moscovita & $350^{\circ} \mathrm{C}$ & Purdy \& Jäger (1976) \\
* referências bibliográficas em Heaman \& Parrish (1991) \\
** não incluido na tabela original
\end{tabular}

No presente trabalho, os valores de $\mathrm{T}_{\mathrm{f}}$ são utilizados na discussão de vários dos dados obtidos. Por exemplo, em inferências a cerca da intensidade de eventos metamórficos, taxa de resfriamento de um corpo ígneo e na interpretação de idades "mistas" K-Ar. Estas últimas constituem um clássico exemplo de processos de perda parcial do isótopo radiogênico. Nestes casos, pode não haver qualquer relação entre a idade radiométrica e o resfriamento abaixo de determinada temperatura. 


\section{CONTEXTO GEOLÓGICO E ACERVO GEOCRONOLÓGICO}

\subsection{ASPECTOS GERAIS DA GEOLOGIA DO QUADRILÁTERO FERRÍFERO}

O contexto geológico do Quadrilátero Ferrífero compreende: (i) terrenos granitognáissicos; (ii) greenstone belts arqueanos, representados pelo Supergrupo Rio das Velhas e faixas correlatas; (iii) unidades metassedimentares do Paleo e Mesoproterozóico (Supergrupo Minas, Grupo Itacolomi e Supergrupo Espinhaço). Um mapa geral da região é apresentado na figura 3. Este mapa foi extraído do Mapa Geológico de Minas Gerais (Pedrosa-Soares et al. 1994), cuja fonte principal, para a região do Quadrilátero Ferrífero, provém do mapa de Dorr (1969). As modificações introduzidas pelo presente autor derivam dos trabalhos realizados no Complexo Belo Horizonte e do mapeamento do Complexo Bonfim efetuado por Carneiro (1992).

A região do Quadrilátero Ferrífero destaca-se por exibir grande complexidade estrutural. Sua mega-estrutura é definida pelas grandes estruturas sinformais e homoclinais do Supergrupo Minas, orientadas NE-SW, N-S e E-W (figuras 3 e 5). As questões relacionadas à evolução estrutural serão comentadas na seção 3.3 .

Os terrenos granito-gnáissicos compreendem diversos complexos, conforme divisão esboçada por Herz (1970). Estes são os complexos Caeté, Bonfim, Bação e Belo Horizonte (Figura 3). Os contatos com as unidades supracrustais adjacentes são de natureza tectônica. Esses complexos metamórficos são constituídos, majoritariamente, por ortognaisses do tipo TTG (Figueiredo \& Barbosa 1993), migmatizados ou não. Apresentam intrusões granitóides, na forma de veios ou corpos circunscritos, anfibolitos e pegmatitos. Os complexos metamórficos foram formados, principalmente, em condições da fácies anfibolito (Roeser et al. 1987).

O único complexo a ter sua geologia detalhada é o Complexo Bonfïm, na sua porção setentrional (Carneiro 1992). Dois tipos de gnaisses estão presentes; o Gnaisse Alberto Flores e o Gnaisse Souza Noschese, definidos originalmente por Herz (1970). O primeiro é bandado e localmente migmatizado, possuindo composição granodiorítica a tonalítica 


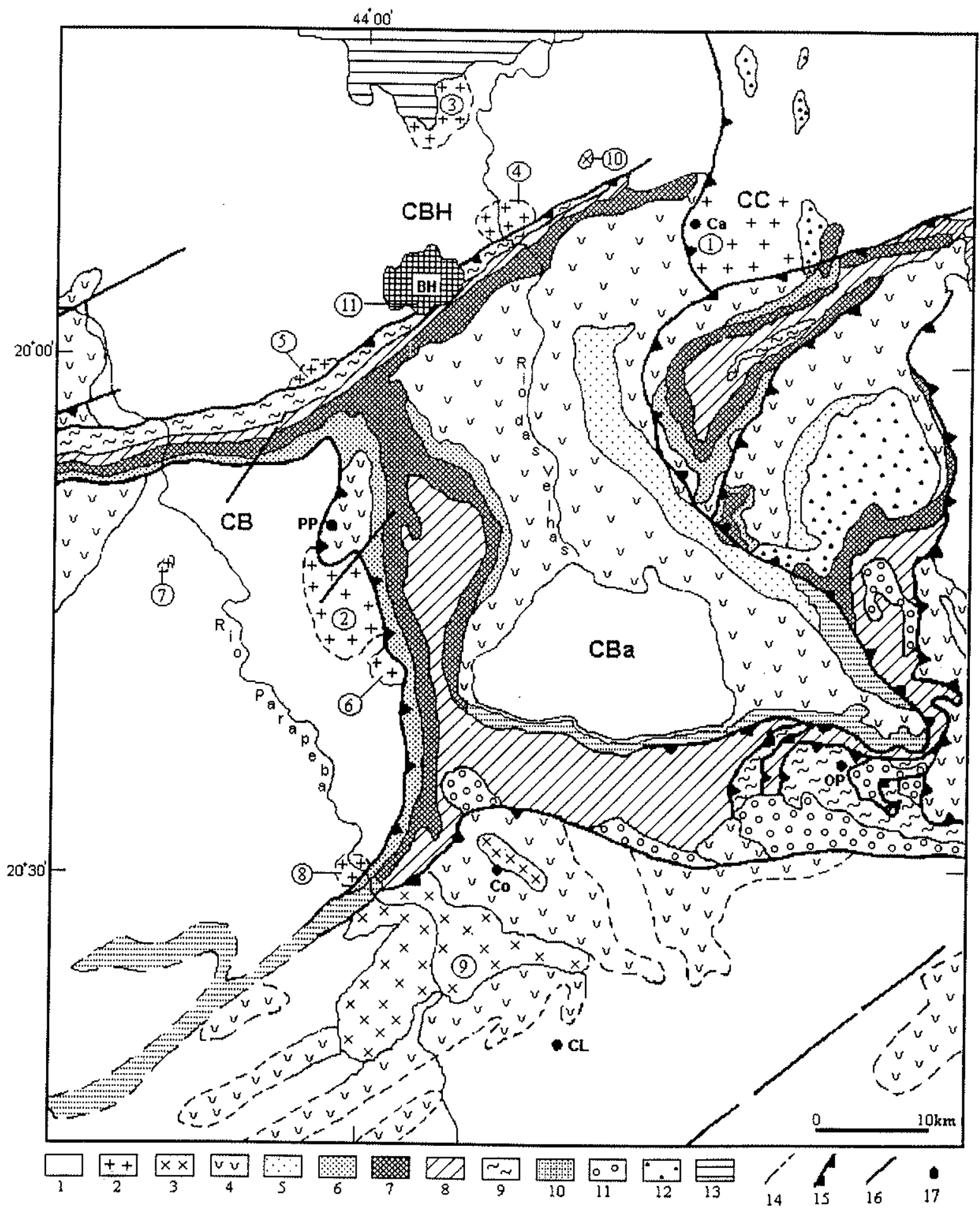

Figura 3: Mapa geológico do Quadrilátero Ferrifero (modificado do Mapa Geológico de Minas Gerais, Pedrosa-Soares et al. 1994). 


\section{Legenda da figura 3:}

\section{Terrenos Granito-Gnáissicos:}

CBH: Complexo Belo Horizonte; CB: Complexo Bonfïm: CC: Complexo Caeté; CBa: Complexo Bação

1-gnaisses e migmatitos; 2-granitóides arqueanos (1. Granodiorito Caeté, 2. Tonalito Samambaia. 3. Granito Santa Luzia, 4. Granito General Carneiro, 5. Granodiorito Ibirite, 6. Granodiorito Mamona, 7. Granito Brumadinho, 8. Granito Salto do Paraopeba); 3-Granitóides paleoproterozóicos (9. Batólito Alto Maranhão, 10. Granito Córrego do Brumado, 11. Granito Morro da Pedra);

\section{Greenstone Belt Arqueano:}

Supergrupo Rio das Velhas: 4-Grupo Nova Lima; 5-Grupo Maquiné;

\section{Unidades Supracrustais Proterozóicas:}

Supergrupo Minas: 6-Grupo Caraça; 7-Grupo Itabira; 8-Grupo Piracicaba; 9-Grupo Sabará; 10-Supergrupo Minas indiviso;

11-Grupo Itacolomi; 12-Supergrupo Espinhaço; 13-Grupo Bambuí

Outros símbolos: 14-contato geológico, tracejado quando inferido; 15-falha de empurrão; 16falha indeterminada; 17-localidades (BH. Belo Horizonte, Ca. Caeté, PP. Piedade do Paraopeba, OP. Ouro Preto, Co-Congonhas do Campo, CL. Conselheiro Lafaiete).

(trondhjemítica) e exibindo marcante foliação milonítica N-S. O segundo possui composição granítica e foliação menos desenvolvida. Carneiro (1992) observou também a intrusão de duas gerações de granitóides, designados Tonalitos Samambaia e Granito Brumadinho. Este último ocorre na forma de veios fracamente deformados, cortando a foliação N-S regional dos gnaisses mais antigos (Gnaisse Alberto Flores).

O Supergrupo Rio das Velhas foi individualizado por Dorr et al. (1957). Sua unidade basal, o Grupo Nova Lima, encerra os principais depósitos auríferos do Quadrilátero Ferrífero e possui natureza vulcano-sedimentar. As rochas vulcânicas compreendem komatiítos com textura spinifex (Schorscher 1978, Schorscher et al. 1982, Noce et al. 1990), basaltos toleíticos, rochas vulcanoclásticas e vulcânicas félsicas (Ladeira 1980, 1981, Oliveira et al. 1983, Vial et al. 1987, Noce et al. 1992, etc.). A porção sedimentar é de natureza clástica e química, predominantemente composta por filitos cloríticos, somados à formação ferrífera, grauvaca, quartzito e conglomerado (Dorr 1969, Ladeira 1980). Segundo Schrank \& Silva (1993), parte importante do pacote sedimentar é representado por seqüências turbidíticas de composição básica a félsica.

Não existe uma subdivisão estratigráfica válida para o Grupo Nova Lima como um todo. Tal fato é conseqüência da intensa deformação, processos de alteração pervasivos e profundo 
intemperismo, aliados à ausência de cartografia detalhada em muitas áreas. Schrank \& Silva (1993) apresentam uma síntese atual do conhecimento geológico sobre o Grupo Nova Lima, incluindo estudo comparativo das várias colunas locais, além de extensa listagem bibliográfica.

A unidade de topo do Supergrupo Rio das Velhas. Grupo Maquiné, tem ocorrência restrita à porção centro-leste do Quadrilátero Ferrífero, sendo constituída por quartzitos e conglomerados, subordinadamente filitos e grauvacas (Door 1969).

Faixas de rochas vulcano-sedimentares, geralmente consideradas correlatas ao Supergrupo Rio das Velhas, estendem-se por áreas adjacentes ao Quadrilátero Ferrífero. A noroeste, a faixa de Itatiaiuçu-Pitangui foi datalhada por Romano (1989). A sul e sudoeste, diversas faixas descontínuas distribuem-se entre Conselheiro Lafaiete e Lavras (Guild 1957, Pires 1977, Grossi Sad et al. 1983 , etc.).

O Supergrupo Minas sobrepõe-se às rochas dos complexos metamórficos e Supergrupo Rio das Velhas, geralmente em contato tectônico. A coluna litoestratigráfica do Supergrupo Minas foi estabelecida por Dorr (1969), dividida em três grupos: unidade clástica basal (Grupo Caraça), unidade química intermediária (Grupo Itabira) e unidade clástica de topo (Grupo Piracicaba). $\mathrm{O}$ contato entre os dois primeiros grupos é transicional, enquanto o Grupo Piracicaba exibe discordância erosiva na base.

O Grupo Caraça apresenta, na base, a Formação Moeda, constituída por quartzitos com intercalações de filito e níveis conglomeráticos (principalmente em posição basal). A presença de conglomerados auríferos-uraniniferos é característica dessa unidade. A Formação Moeda transiciona para a Formação Batatal, onde predominam filitos sericíticos, por vezes carbonosos ou ferruginosos.

O Grupo Itabira inicia pela Formação Cauê, composta por itabiritos (formações ferríferas bandadas do tipo Lago Superior). Os itabiritos são quartzosos ou dolomíticos, mais raro anfibolíticos, e encerram corpos lenticulares de minério de ferro rico. Filitos ferruginosos e dolomitos são também descritos nessa unidade. A Formação Gandarela, no topo do grupo, exibe mármores dolomíticos, subordinadamente itabiritos e filitos.

A. unidade basal do Grupo Piracicaba, Formação Cercadinho, caracteriza-se pela alternância de quartzitos e filitos, freqüentemente ferruginosos. A Formação Fecho do Funil é constituída por filitos quartzosos, filitos dolomíticos e lentes de dolomito. As formações Taboões (ortoquartzitos) e Barreiro (filitos grafitosos) são de ocorrência restrita.

A unidade superior do Grupo Piracicaba. Formação Sabará. é constituída por clorita xistos e filitos. metagrauvacas. metatufos, metaconglomerados, quartzitos e rara formação ferrífera. Segundo Dorr (1969), a Formação Sabará possui espessura máxima de $3.000 \mathrm{~m}$, aproximando-se da espessura máxima atingida pelo conjunto das demais unidades do Supergrupo Minas, que é de 
3.500 m. Sua espessura e litologia distintiva justificam a elevação da Formação Sabará à categoria de grupo, em conformidade com sugestão de Barbosa (1968) e Ladeira (1980).

Em termos de metamorfismo, o conjunto formado pelos supergrupos Rio das Velhas e Minas encontra-se, majoritariamente, no domínio da fácies xisto verde (zona da clorita), podendo atingir a fácies anfibolito baixo junto às bordas leste e sudeste do Quadrilátero Ferrifero. Herz (1978) constatou também a presença de paragêneses de grau mais elevado, com granada e estaurolita, em auréolas metamórficas adjacentes aos complexos Bação e Belo Horizonte.

As rochas que constituem o Grupo Itacolomi foram separadas do Supergrupo Minas por Guimarães (1931), com base na existência de uma discordância angular entre as duas unidades. A distribuição do Grupo Itacolomi é restrita às porções sudeste e sul do Quadrilátero Ferrifero. $\mathrm{Na}$ sua área-tipo (região de Ouro Preto), é composto por quartzitos, metaconglomerados e grit (Dorr 1969). A maior parte do material detrítico seria proveniente da erosão de rochas do Supergrupo Minas (Barbosa 1968).

O Supergrupo Espinhaço é representado pelo pacote quartzítico da Serra das Cambotas, localizada na região nordeste do Quadrilátero Ferrifero. Estes quartzitos, originalmente, foram colocados no Grupo Tamanduá de Simmons \& Maxwell (1961). A posição estratigráfica desta unidade foi sempre controvertida, por incluir pacotes de rocha distintos, tectonicamente justapostos (Crocco-Rodrigues et al. 1991). Desta forma, a designação Grupo Tamanduá tem sido abandonada, enquanto a correlação dos quartzitos da Serra das Cambotas com o Supergrupo Espinhaço é amplamente aceita (Crocco-Rodrigues et al. 1992, Freitas et al. 1992). Os quartzitos da Serra do Caraça e da Serra de Ouro Branco, de posição estratigráfica duvidosa, poderiam também ser correlacionados ao Supergrupo Espinhaço (Almeida-Abreu 1993). Entretanto, Alkmim (1985) correlaciona os quartzitos da Serra de Ouro Branco ao Grupo Itacolomi, enquanto os da Serra do Caraça são atribuídos à Formação Moeda por Ribeiro-Rodrigues et al. (1993).

Dentro do quadro geológico regional do Quadrilátero Ferrífero, deve-se destacar também a presença de enxames de diques máficos. Estes são proeminentes nos terrenos granito-gnássicos a oeste de Belo Horizonte, mas cortam também as unidades supracrustais paleo e mesoproterozóicas. Os diques incluem desde tipos metamorfoseados no fácies anfibolito até aqueles com textura ígnea preservada. Descrições detalhadas podem ser encontradas, dentre outros, em Teixeira et al. (1988), Silva et al. (1992) e Carneiro (1992). 


\subsection{ACERVO GEOCRONOLÓGICO}

\subsubsection{Determinações Rb-Sr e K-Ar}

Na síntese sobre a geocronologia da região do Quadrilátero Ferrifero, apresentada por Cordani et al. (1980), são discutidas todas as determinações Rb-Sr e K-Ar disponiveis até aquela data, incluindo as de Herz (1970) e Besang et al. (1977). A maioria das análises Rb-Sr provinha de gnaisses e granitóides do Complexo Bação e regiões a sul e leste do Quadrilátero Ferrifero. Esses dados foram lançados em diagramas isocrônicos de referência, agrupando vários afloramentos, definindo um alinhamento com idade de $2.750 \mathrm{Ma}$ e outro de $2.100 \mathrm{Ma}$. A primeira idade foi atribuída a eventos geradores de rocha no Arqueano (formação dos terrenos granito-gnáissicos e greenstone belts) e a segunda ao metamorfismo transamazônico.

Em relação aos dados K-Ar, Cordani et al. (1980) ressaltaram a grande dispersão das idades existentes, embora se verificasse significativa concentração no intervalo $650-450 \mathrm{Ma}$, o que evidenciaria a atuação termal do Evento Brasiliano.

Outros trabalhos de síntese, incluíndo dados $\mathrm{Rb}-\mathrm{Sr}$ e $\mathrm{K}-\mathrm{Ar}$ adicionais àqueles tratados por Cordani et al. (1980), são os de Teixeira (1982) e Machado $\mathrm{F}^{\circ}$ et al. (1983).

Baseado nas determinações Rb-Sr, Teixeira (1985) concluiu que o embasamento do Cráton do São Francisco, a oeste do Quadrilátero Ferrifero, é constituído por núcleos arqueanos de idades distintas (entre 3.000 e $2.600 \mathrm{Ma}$ ). Determinações nas adjacências do Quadrilátero Ferrifero, especialmente a noroeste deste, incluem uma isócrona de $2.803 \pm 70 \mathrm{Ma}$, em gnaisse regional e veios félsicos da região de Esmeraldas-Cachoeira da Prata. Outras duas isócronas, de $2.727 \pm 17 \mathrm{Ma}$ e $2.798 \pm 43 \mathrm{Ma}$, foram obtidas em gnaisses tonalíticos da região de Itaúna. Em todas as análises, as baixas razões iniciais ${ }^{87} \mathrm{Sr} /{ }^{86} \mathrm{Sr}$ são indicativas de eventos de metamorfismo em época pouco posterior à formação da rocha.

Teixeira (1985) demonstrou que, na região a oeste do Quadrilátero Ferrífero, as idades KAr são, predominantemente, relacionadas ao Evento Transamazônico (2.200-1.900 Ma). Idades $\mathrm{K}-\mathrm{Ar}$ (em biotita) mesoproterozóicas foram obtidas no embasamento granito-gnáissico a oeste de Belo Horizonte. No Complexo Bonfim, as idades K-Ar concentram-se entre 2.150-1.950 Ma para anfibólios e 1.100-700 Ma para biotitas (Carneiro 1992). De um modo geral, pode-se concluir que o Evento Brasiliano afeta apenas parcialmente o sistema isotópico K-Ar, na região ocidental do Quadrilátero Ferrífero. 
O Complexo Granulítico de Acaiaca. a leste do Quadrilátero Ferrifero, foi investigado geocronologicamente por Teixeira et al. (1987), pelos métodos $\mathrm{Rb}-\mathrm{Sr}$ e $\mathrm{Pb}-\mathrm{Pb}$. Obteve-se uma isócrona $\mathrm{Rb}$-Sr de $1.991 \pm 42 \mathrm{Ma}$, com R.I. $=0,7061$, ao passo que a isócrona $\mathrm{Pb}-\mathrm{Pb}$ forneceu a idade de 2.017+538/-854 Ma e $\mu_{1}$ de 8,641. A combinação dos parâmetros petrogenéticos de Sr e $\mathrm{Pb}$ sugeria tratar-se de material mais antigo, retrabalhado pelo metamorfismo de alto grau do Evento Transamazônico.

Belo de Oliveira \& Teixeira (1990) dataram o granodiorito-gnaisse do Complexo Caeté, em diferentes graus de milonitização. Foram construídas quatro isócronas $\mathrm{Rb}-\mathrm{Sr}$, fornecendo idades entre $2.250 \pm 124 \mathrm{Ma}$, para rochas pouco deformadas, e $2.130 \pm 101 \mathrm{Ma}$, para rochas miloníticas. As razões iniciais eram altas, variando entre 0,7061 e 0,7084 . Os resultados foram interpretados como decorrentes do metassomatismo associado à milonitização. A idade de cristalização dos granodioritos é arqueana, como demonstrado por datação U-Pb (Machado et al. 1992).

Datações Rb-Sr do Complexo Bonfim são reportadas por Carneiro (1992) e Carneiro \& Teixeira (1992). As idades são conflitantes com datações U-Pb e outras evidências geológicas, o que levou os autores a atribuí-las a pertubações do sistema isotópico em função da percolação de fluidos. Por sua vez, este processo estaria associado a reativações de zonas de cisalhamento do Arqueano no decorrer do Mesoproterozóico (Carneiro \& Teixeira 1992).

Um expressivo enxame de diques máficos estende-se para noroeste do Quadrilátero Ferrífero, a partir da área do Complexo Belo Horizonte. Um estudo K-Ar preliminar destes diques (Teixeira et al. 1988) revelou dois grupos principais: o mais expressivo foi afetado pelo metamorfismo transamazonico, entre 2.100-1.850 Ma, enquanto o segundo estaria associado à abertura da bacia Espinhaço, entre 1.700-1.500 Ma. Processos de perda de Ar ligados ao Evento Brasiliano foram também detectados. As determinações $\mathrm{Rb}$-Sr e K-Ar para esta mesma região noroeste do Quadrilátero Ferrífero, devidas a Romano (1989), foram de $1.870 \pm 37 \mathrm{Ma}$ (Rb-Sr em rocha total) e $1773 \pm 30 / 1.745 \pm 30 \mathrm{Ma}$ (K-Ar em biotita).

\subsubsection{Determinações $\mathbf{P b}-\mathbf{P b}$}

Thorpe et al. (1984) realizaram determinações $\mathrm{Pb}-\mathrm{Pb}$ em sulfetos (galenas), provenientes de corpos mineralizados em ouro do Grupo Nova Lima. Concluíram que a mineralização aurifera, à qual associam-se as galenas analisadas, teria idade mínima de $2.710 \mathrm{Ma}$ (e máxima de $3.000 \mathrm{Ma}$ ). Remobilizações das zonas auríferas, associadas a eventos proterozóicos, parecem ter ocorrido há 2.425-2.410 Ma, 2.175-2.100 Ma e 600 Ma. 
O mesmo tema de investigação foi retomado por Dewitt et al. (1994). As determinações $\mathrm{Pb}-\mathrm{Pb}$ em sulfetos da Mina de São Bento confirmaram a idade neoarqueana da mineralização aurifera.

Babinski et al. (1991, 1993) utilizaram a metodologia $\mathrm{Pb}-\mathrm{Pb}$ na datação de rochas carbonáticas do Supergrupo Minas. Carbonatos estromatolíticos com deformação muito incipiente, pertencentes à Formação Gandarela, forneceram uma isócrona de $2.420 \pm 25 \mathrm{Ma}$. Esta idade foi interpretada como a idade de deposição dos carbonatos. Outra rocha carbonática analisada, do Grupo Piracicaba, mostrava evidências de metamorfismo mais severo. A isócrona obtida, $2.050 \pm 230 \mathrm{Ma}$, foi relacionada ao metamorfismo transamazônico.

\subsubsection{Determinações $\mathrm{Sm}-\mathrm{Nd}$}

As primeiras determinações Sm-Nd são devidas a Romano (1989), na região a noroeste do Quadrilátero Ferrífero. Dois corpos granitóides apresentaram idades-modelo Sm-Nd (TDM) entre 2.770 e $2.780 \mathrm{Ma}$, caracterizando um importante período de acreção crustal.

Teixeira et al. (1994) apresentaram idades-modelo Sm-Nd (TDM) para o Complexo Campo Belo e Complexo Bonfim. Os gnaisses, tonalitos e granitos do Complexo Bonfim revelaram idades no intervalo 3.000-2.800 Ma. Como os plutonitos analisados possuíam idades de cristalização bem definidas pelo método $\mathrm{U}-\mathrm{Pb}$, pode-se concluir pela participação de crosta siálica mais antiga no processo de geração de alguns destes corpos, enquanto outros foram originados diretamente do manto.

\subsubsection{Determinações U-Pb}

Os dados $\mathrm{U}-\mathrm{Pb}$ disponiveis para a região possuem caráter distinto. Alguns foram obtidos segundo o método convencional, cada fração analisada sendo composta por grandes populações de zircão, incluindo tipologias diferentes, não submetidas ao processo de abrasão. Esses dados, geralmente, são muito discordantes (consequentemente mais imprecisos), enquanto a possivel mistura de zircões gerados em épocas distintas aumenta a incerteza quanto ao significado geológico das idades dos interceptos de discórdias. As idades obtidas segundo o método de alta precisão, descrito no capítulo 2 , são muito mais confiáveis. 
Devem-se a Delhal \& Demaiffe (1985) as primeiras idades U-Pb do Quadrilátero Ferrífero, obtidas segundo o método convencional, em gnaisses do Complexo Bação. Foram analisadas duas frações de zircão de uma amostra e frações de zircão e titanita de outra amostra. Todas as análises são muito discordantes e os pontos analíticos não se alinham. Os autores construíram duas discórdias de dois pontos, que forneceram um intercepto inferior em torno de $760 \mathrm{Ma}$ e interceptos superiores a 2.570 e $2.820 \mathrm{Ma}$. O significado geológico destas idades é duvidoso. Entretanto, apontam para a idade arqueana do Complexo Bação, em conformidade com as determinações Rb-Sr da literatura.

Determinações U-Pb na região de Barbacena, situada por volta de $100 \mathrm{~km}$ a sul do Quadrilátero Ferrífero, foram efetuadas por Delhal \& Demaiffe (1985) e Söllner et al. (1991). As análises destes últimos autores seguiram as técnicas básicas do método de alta precisão, mas sem abrasão. Os dados de Söllner et al. (1991) determinaram eventos de cristalização de zircão há

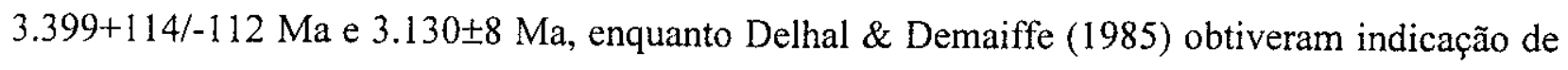
um evento há cerca de $2.900 \mathrm{Ma}$. Uma fração quase concordante de titanita forneceu idade em torno de $600 \mathrm{Ma}$ (Delhal \& Demaiffe 1985), apontando a cristalização ou resetting deste mineral no Neoproterozóico. Tal fato sugere metamorfismo a temperaturas em torno de $500^{\circ} \mathrm{C}$, associado ao Evento Brasiliano.

Romano (1989) e Romano et al. (1991) analisaram frações de zircão de dois corpos granitóides provenientes da região a noroeste do Quadrilátero Ferrifero, o Granodiorito Caio Martins e o Granito Mateus Leme. As idades obtidas foram, respectivamente, $2.593 \pm 18 \mathrm{Ma} \mathrm{e}$ $2.755 \pm 13 \mathrm{Ma}$. Os autores não utilizaram a técnica da abrasão e os pontos analíticos são muito discordantes.

Uma idade preliminar, de $655 \mathrm{Ma}$, foi obtida em zircão e baddeleyita de um dique máfico com textura ígnea preservada (Silva et al. 1992), localizado próximo a lbirité, região noroeste do Quadrilátero Ferrífero.

Avanço decisivo no conhecimento geocronológico do Quadrilátero Ferrífero adveio das datações U-Pb de alta precisão, reportadas por Machado et al. (1989a, 1992), Carneiro (1992) e Machado \& Carneiro (1992). Como tais datações serão repetidamente comentadas no decorrer do texto, será apresentado aqui apenas um quadro sinóptico dos resultados (Tabela 3). 
Tabela 3: Sumário dos dados U-Pb de alta precisão para o Quadrilátero Ferrifero (Machado et al.. 1989 e 1992; Machado \& Carneiro 1992. Carneiro 1992).

\begin{tabular}{|c|c|c|c|c|}
\hline $\begin{array}{l}\text { Litotipo/ } \\
\text { Unidade }\end{array}$ & Proveniência & Mineral & Idade (Ma) & Interpretaçāo \\
\hline $\begin{array}{c}\text { Gnaisse Alberto } \\
\text { Flores }\end{array}$ & Complexo Bonfïm & zircão & $2.772 \pm 6$ & metamorfismo \\
\hline Tonalito Samambaia & Complexo Bonfim & $\begin{array}{l}\text { zircão } \\
\text { titanita }\end{array}$ & $2.780+3 /-2$ & cristalização \\
\hline Granodiorito Caeté & Complexo Caeté & zircão & $2.776+7 /-6$ & cristalização \\
\hline $\begin{array}{c}\text { Metavulcânica } \\
\text { ácida/Grupo Nova } \\
\text { Lima }\end{array}$ & $\begin{array}{l}\text { áreas de Caeté e } \\
\text { Piedade do Paraopeba }\end{array}$ & zircão & $\begin{array}{c}2.776+23 /-10 \\
2.772 \pm 6\end{array}$ & cristalização \\
\hline $\begin{array}{l}\text { Granodiorito } \\
\text { Mamona }\end{array}$ & Complexo Bonfim & zircão & $2.721 \pm 3$ & cristalização \\
\hline Granito Brumadinho & Complexo Bonfim & zircão & $2.703+24 /-23$ & cristalização \\
\hline Anfibolito & Complexo Bação & titanita & $2.059 \pm 6$ & metamorfismo \\
\hline Pegmatitos & Complexo Bação & monazita & $\begin{array}{l}>2.030 \\
>2.022\end{array}$ & cristalização \\
\hline $\begin{array}{l}\text { Metagrauvaca/ } \\
\text { Grupo Sabará }\end{array}$ & $\begin{array}{c}\text { área oeste da Serra do } \\
\text { Curral }\end{array}$ & zircão & $2.125 \pm 4$ & $\begin{array}{l}\text { idade máxima } \\
\text { de deposição }\end{array}$ \\
\hline
\end{tabular}

\subsection{ARCABOUÇO GEOLÓGICO REGIONAL E EVOLUÇÃO}

O Cráton do São Francisco, na definição de Almeida (1977), constitui uma plataforma cujo embasamento consolidou-se em tempos pré-brasilianos. O Quadrilátero Ferrífero representa uma área de exposição desse embasamento, situada na transição entre a zona mais estável, a oeste, e as faixas marginais brasilianas a leste e sudeste (Faixa Araçuaí e Faixa Alto Rio Grande). Esse contexto fica bem evidenciado no âmbito da revisão dos limites do cráton proposta por Alkmim et al. (1993). O limite corta a porção oriental do Quadrilátero Ferrifero (Figura 4), ao longo de um sistema de falhas de empurrão N-S. com merguihos para leste, que afetam os supergrupos Minas e Rio das Velhas. Esses falhamentos constituem parte do Sistema Cambotas-Fundão (Figura 5), descrito por Chemale Jr. et al. (1991), conectando-se, a norte, com as falhas 


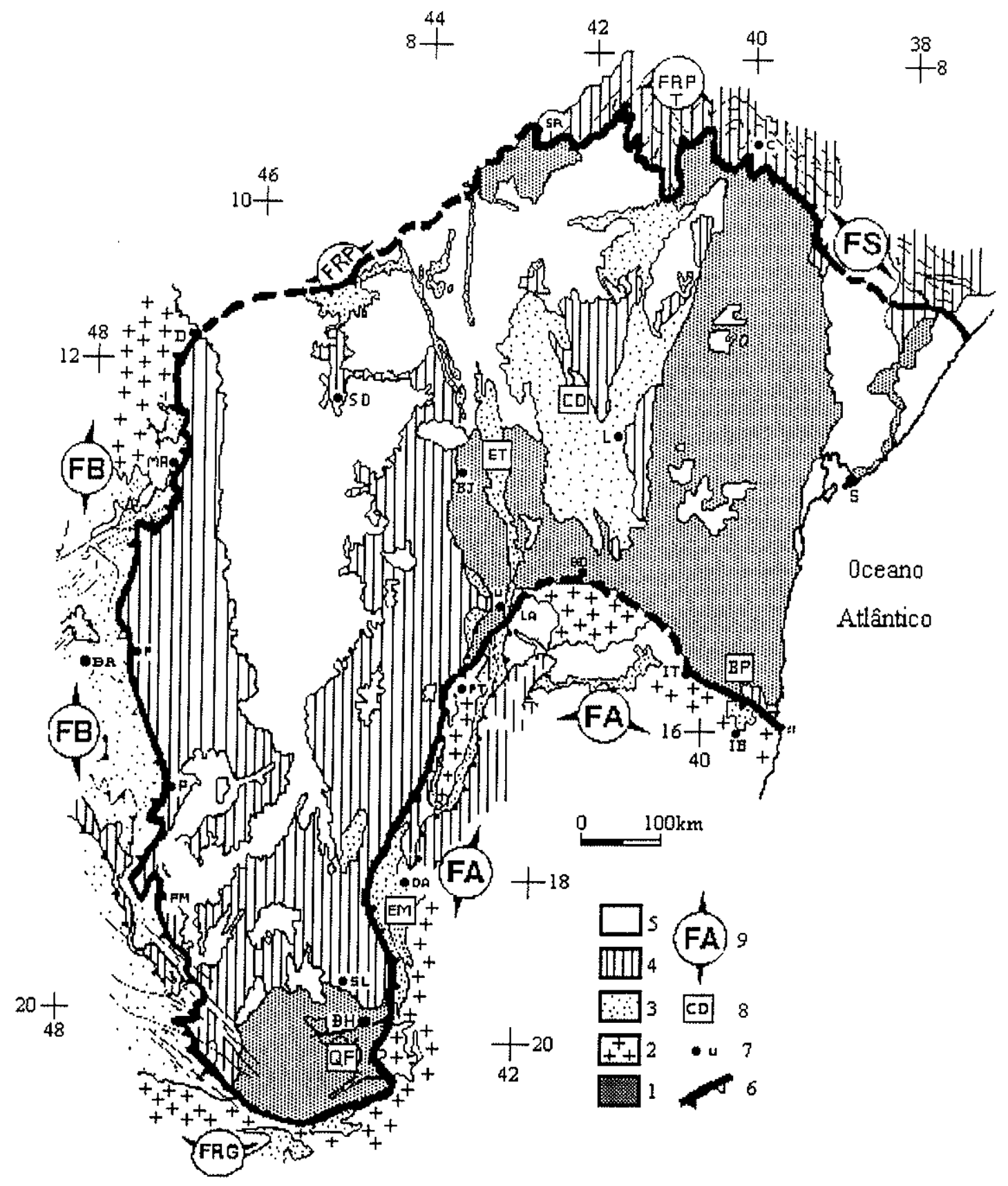

Figura 4: Delimitação atualizada e significado dos limites do Cráton do São Francisco (extraído de Alkmim et al. 1993).

1. Embasamento do cráton, incluindo supracrustais mais velhas que $1,8 \mathrm{Ga}$ e rochas ígneas. 2. Embasamento envolvido nos processos de deformação e metamorfismo do Evento Brasiliano. 3. Unidades mesoproterozóicas. 4. Unidades neoproterozóicas. 5. Coberturas fanerozóicas. 6.Limite do cráton. Dentes em negrito e vazados indicam, respectivamente, falha de empurrão de alto e baixo ângulo. 7. Cidades: SR. São Raimundo Nonato; C. Curaçá; D. Dianópolis; SD. São Desidério; L. Lençois; MA. Monte Alegre de Golás; BJ. Bom Jesus da Lapa; S. Salvador; NR. Nova Roma; BD. Brumado; U. Urandi; LA. Licínio de Almeida; F. Formosa: IT. Itapetinga; BR. Brasilia; B. Belmonte; PT. Porteirinha; IB.Itapebi; P. Paracatu; V. Vazante; DA. Diamantina; P. Patos de Minas: SL. Sete Lagoas; BH. Belo Horizonte. 8. Provincias fisiográficas e geológicas: CD. Chapada Diamantina; ET. Espinhaço Setentrional; BP. Bacia do Rio Pardo; EM. Espinhaço Meridional; QF. Quadrilátero Ferrifero. 9. Faixas de dobramento marginais, brasilianas: FA. Faixa Araçuaí; FRG. Faixa Alto Rio Grande; FB. Faixa Brasília; FRP. Faixa Rio Preto; FRPT. Faixa Riacho do Pontal; FS. Faixa Sergipana. 
de empurrão responsáveis pelo posicionamento do Supergrupo Espinhaço Meridional sobre a cobertura cratônica, representada pelo Grupo Bambuí.

Alkmim et al. (1993) admitem que a região do Quadrilátero Ferrifero a oeste do Sistema Cambotas-Fundão sofreu também a influência da deformação brasiliana. Entretanto, como esta deformação teria sido induzida a partir da zona interna da faixa móvel. situada a leste do Quadrilátero Ferrífero, tal fato não descaracterizaria o limite proposto.

Ao focalizar a área cratônica, Teixeira (1985) apresenta a região do Quadrilátero Ferrifero sob uma perspectiva diferente. Esta estaria incluída em uma extensa faixa móvel do Paleoproterozóico (Cinturão Mineiro) que bordeja um núcleo cratônico arqueno a oeste. A deformação no interior da faixa móvel teria provocado intenso retrabalhamento do embasamento arqueano e dobramento da cobertura representada pelo Supergrupo Minas (e.g. Teixeira \& Figueiredo 1991, Carneiro 1992).

As duas visões não são excludentes, mas salientam o posicionamento geotectônico peculiar do Quadrilátero Ferrífero. Este situa-se no domínio de duas faixas móveis aproximadamente paralelas e parcialmente superpostas, desenvolvidas durante os eventos Transamazônico e Brasiliano.

As principais estruturas do Quadrilátero Ferrífero são apresentadas no mapa da figura 5. Diversos autores têm abordado o tema da evolução estrutural e tectônica desta região. Dentre os modelos de abrangência regional pode-se citar os de Dorr (1969), Ladeira e Viveiros (1984), Marshak \& Alkmim (1989), Belo de Oliveira \& Teixeira (1990) e Chemale Jr. et al. (1991, 1994). Uma síntese crítica centrada nos modelos mais recentes será apresentada nos parágrafos seguintes.

A maioria dos modelos focaliza a evolução pós-arqueana do Quadrilátero Ferrífero, admitindo dois episódios tectônicos principais ligados aos eventos Transamazônico e Brasiliano. A natureza da tectônica transamazônica, e seu papel na estruturação do Quadrilátero Ferrífero, tem sucitado controvérsias. Para Marshak \& Alkmim (1989), o Evento Transamazônico levou ao desenvolvimento de um cinturão de cavalgamento e dobramento com transporte de SE para NW, associado a metamorfismo regional e responsável pelas grandes estruturas NE-SW. Belo de Oliveira \& Teixeira (1990) também consideram que a deformação transamazônica foi de natureza compressional, tendo provocado a reversão dos falhamentos normais da fase de abertura da bacia Minas, resultando na nucleação dos mega-sinclinais do Quadrilátero Ferrífero.

Chemale Jr. et al. (1991, 1994) caracterizaram a deformação transamazônica como um evento extensional, associado a dois possiveis cenários geotectônicos: (i) tectonismo extensional no antepaís de uma zona de subducção transamazônica mergulhando para oeste; (ii) separação continental e consequente movimentação vertical de blocos. 


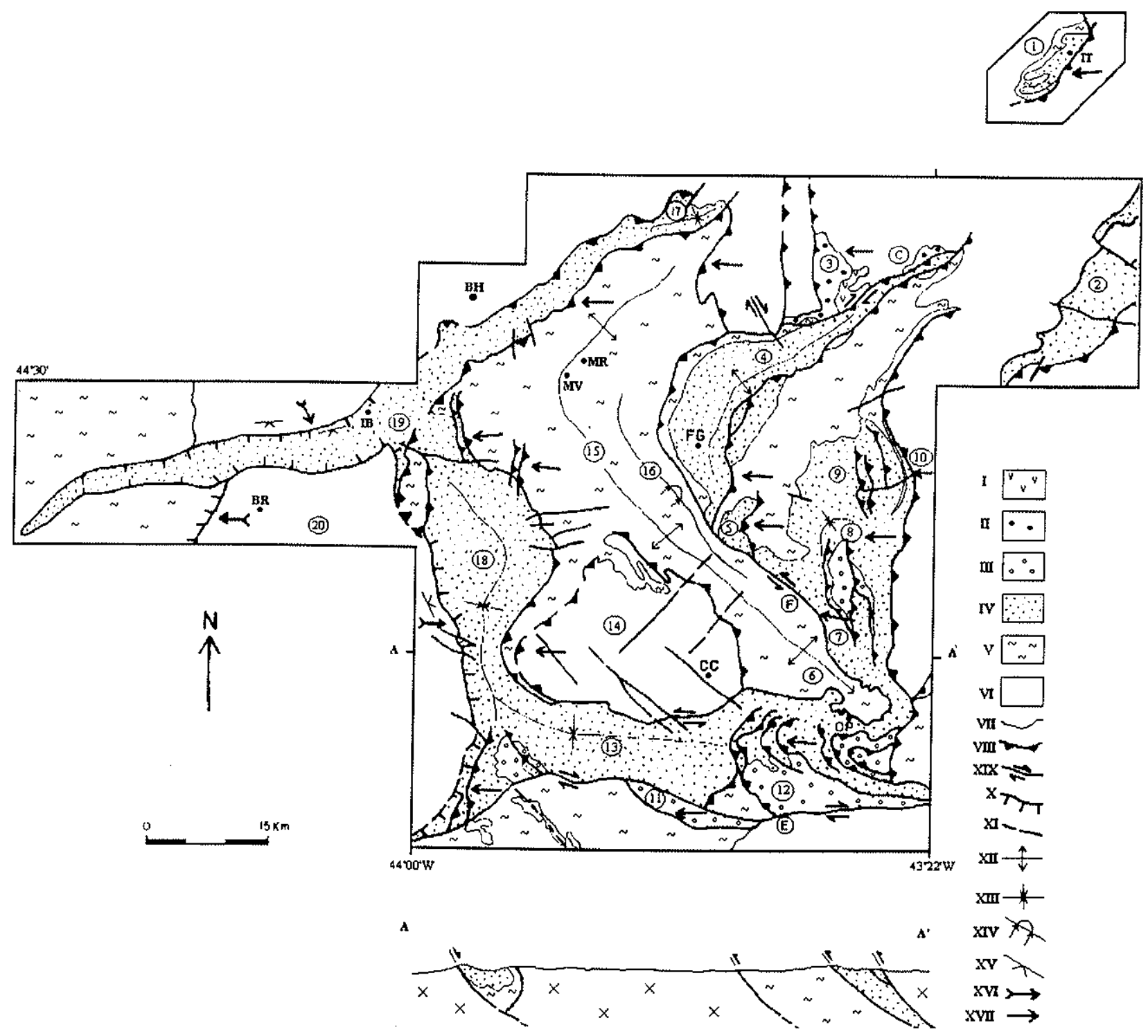

Figura 5: Mapa estrutural do Quadrilátero Ferrifero (extraido de Chemale Jr. et al. 1991).

I. rochas metabásicas. II. Supergrupo Espinhaço indiviso. III. Grupo Itacolomi. IV. Supergrupo Minas. V. Supergrupo Rio das Velhas. VI. Terrenos granito-gnáissicos. VII. contato. VIII. empurrão. XIX. zona de falha direcional. X. zona de falha extensional (dúctil a dúctil-rúptil). XI. falha. XII. anticlinal. XIII. sinclinal. XIV. sinclinal invertido. XV. foliação extensional. XVI. lineação mineral extensional. XVII. indicador de transporte tectônico. Cidades e localidades: BH. Belo Horizonte; BR. Brumadinho; CC. Congonhas do Campo; FG. Fazenda Gandarela; IB. Ibirité; IT. Itabira: MR. Mina Raposos; MV. Morro Velho; OP. Ouro Preto. Estruturas e acidentes geográficos: 1. Sinclinório de Itabira; 2. Sinclinório de João Monlevade; 3. Serra das Cambotas; 4. Sinclinal Gandarela: 5. Sinclinal de Ouro Fino; 6. Anticlinal de Mariana; 7. Sinclinal Conta História: 8. Sinclinal de Alegria; 9. Serra do Caraça; 10. front Fazendão; 11. Serra de Ouro Branco; 12. Serra de Itatiaia; 13. Sinclinal de Dom Bosco; 14. Complexo Bação; 15. soerguimento Rio das Velhas; 16. Sinclinal Vargem do Lima; 17. Sinclinal Serra da Piedade: 18. Sinclinal da Moeda; 19. Serra do Curral; 20. Complexo Bonfim; C. Falha das Cambotas; E. Falha do Engenho; F. Falha do Fundão. 
De acordo com o modelo de Chemale Jr. et al. (1991, 1994), as mega-dobras sinformais e antiformais resultariam do soerguimento do embasamento e consequente subsidência do pacote supracrustal (Supergrupo Minas), em um mecanismo semelhante ao formador dos metamorphic core complexes descritos na região oeste da América do Norte (e.g. Davis \& Coney 1979). O metamorfismo do Supergrupo Minas seria causado pelo soterramento durante a subsidência. Por sua vez, o soerguimento dos complexos granito-gnáissicos teria provocado sua justaposição com rochas supracrustais em temperaturas mais baixas, resultando na formação das auréolas metamórficas. Hipótese similar para a formação das auréolas já havia sido apresentada por Drake \& Morgan (1980) e um modelo para este processo foi desenvolvido por Marshak et al. (1992).

Autores como Dorr (1969), Ladeira (1976) e Drake \& Morgan (1980) também postularam a atuação de uma tectônica de ascensão de blocos no Quadrilátero Ferrífero. Além do Complexo Bação, em geral apontado como o melhor exemplo desse processo, os complexos Bonfim, Belo Horizonte, Caeté e a Serra do Caraça (um roofed dome para Drake \& Morgan 1980) teriam sofrido movimentos ascencionais.

A evolução do sistema Espinhaço no Mesoproterozóico ter-se-ía refletido, no Quadrilátero Ferrifero, por tectonismo compressional e extensional segundo Marshak \& Alkmim (1989), ou puramente extensional segundo os modelos de Belo de Oliveira \& Teixeira (1990) e Chemale Jr. et al. $(1991,1994)$.

A atuação do Evento Brasiliano, gerando um cinturão de empurrão e dobramento com vergência de E para W, encontra-se muito bem documentada ao longo do Espinhaço Meridional. Diversas evidências demonstram o prolongamento deste cinturão pela porção oriental do Quadrilátero Ferrífero (e.g. Belo de Oliveira \& Vieira 1987) Nessa região, segundo Belo de Oliveira \& Teixeira (1990), a deformação brasiliana define um domínio alóctone oriental, limitado pela Falha de Morro Vermelho (sistema Cambotas-Fundão de Chemale Jr et al. 1991) em conexão com a Falha do Engenho (Figura 5). A oeste deste limite, o domínio para-autóctone exibe estruturação transamazônica. Chemale Jr. et al. (1991, 1994), por sua vez, consideram que a deformação brasiliana afetou todo o Quadrilátero Ferrifero, embora reconheçam que este processo foi menos intenso na sua porção ocidental. O Evento Brasiliano teria provocado tanto a reativação de estruturas mais antigas como a geração de outras estruturas, especialmente falhas de empurrão, afetando de forma mais intensa as unidades supracrustais e as zonas de contato com o embasamento. 


\section{TERRENOS GRANITO-GNÁISSICOS: GEOLOGIA E GEOCRONOLOGIA DO COMPLEXO BELO HORIZONTE}

\subsection{INTRODUÇÃO}

Dentre os temas investigados no presente estudo destaca-se a evolução dos terrenos granito-gnáissicos do Quadrilátero Ferrífero. Foi selecionado o terreno situado a norte da Serra do Curral (região setentrional do Quadrilátero Ferrífero, figura 6), informalmente designado Complexo Belo Horizonte por Ladeira \& Viveiros (1976).

Herz (1970), em parte baseado nos trabalhos de Gair (1962) e Pomerene (1964), descreveu a área a norte da Serra do Curral como constituída por gnaisses de composição granodiorítica, apresentando bandamento composicional. A exposição típica para estas rochas seria encontrada na Pedreira Prado Lopes, situada proximamente à zona central de Belo Horizonte. Trata-se de um gnaisse bem foliado, com bandas félsicas alternando-se com bandas ricas em biotita, comumente apresentando schlieren máficos e xenólitos de anfibolito (Pomerene 1964, Herz 1970). Diques graníticos, com até $1 \mathrm{~m}$ de espessura, cortam os gnaisses em algumas exposições (Herz 1970).

$O$ presente estudo revelou a presença de corpos granitóides foliados, intrusivos nos gnaisses, com dimensões de alguns quilômetros. Foram também incluídas, no Complexo Belo Horizonte, duas faixas isoladas de rochas supracrustais, de natureza vulcano-sedimentar.

Em resumo, o Complexo Belo Horizonte inclui rochas de caráter diverso, o que está em conformidade com a nomenclatura estratigráfica em vigor (Petri et al. 1986). Não existem definições para os limites do complexo. A área investigada neste trabalho é limitada, a sul, pela Serra do Curral e, a norte, pelo Grupo Bambuí. Os limites a leste e oeste são balizados, respectivamente, pela Serra da Piedade e a cidade de Betim. Os litotipos típicos do Complexo Belo Horizonte estendem-se além destes limites, como demonstrado pelos estudos de Schorscher (1992) nos terrenos gnáissicos da região oriental do Quadrilátero Ferrífero. As características geoquímicas e petrográficas dos gnaisses regionais, descritos por Schorscher (1992), são indistinguíveis daquelas das rochas gnáissico-migmatíticas que constituem o arcabouço do Complexo Belo Horizonte. 


\subsection{ASPECTOS GEOLÓGICOS}

O litotipo amplamente dominante no Complexo Belo Horizonte (Figura 6) é um gnaisse cinza-claro, frequentemente exibindo bandamento composicional e feições de migmatização. Esta rocha é referida, no presente trabalho, como Gnaisse Belo Horizonte. As características de campo e composição química desses gnaisses apontam para um caráter orto-derivado, ao contrário do que foi sugerido por Herz (1970).

O Gnaisse Belo Horizonte apresenta feições bastante variáveis. O tipo mais freqüente exibe fino bandamento, da ordem de milímetros a poucos centímetros, resultante da alternância de bandas leucocráticas e outras mais ricas em minerais máficos, essencialmente biotita. Localmente, as bandas atingem espessuras maiores, até $20-30 \mathrm{~cm}$. O bandamento pode apresentar caráter retilíneo e mais ou menos uniforme, ou encontrar-se fortemente dobrado e rompido. Observa-se uma gradação entre porções bandadas e outras de aspecto mais homogêneo, onde a estrutura dominante é uma foliação muito bem desenvolvida.

A intensidade dos fenômenos de migmatização varia de forma muito irregular dentro da área investigada. Nas exposições onde a migmatização do Gnaisse Belo Horizonte foi mais intensa, predominam estruturas do tipo schlieren ou estromática. Observam-se também estruturas do tipo schöllen e o desenvolvimento local de porções nebulíticas.

A presença de encraves máficos é característica em algumas exposições do Gnaisse Belo Horizonte. A maior parte parece originar-se do rompimento de corpos tabulares, concordantes com o bandamento. Apresentam formas irregulares e foram afetados pela migmatização do gnaisse.

O Gnaisse Belo Horizonte é cortado por corpos intrusivos de natureza félsica. Na escala de afloramento, ocorrem veios granitóides, de grão fino a médio, pouco espessos, além de estreitos veios de pegmatito. Foram também identificados dois corpos graníticos (s.s.) circunscritos, de aspecto homogêneo e bem foliados, não afetados por migmatização. Ainda que relações de contato não tenham sido observadas, estes corpos foram interpretados como intrusivos no Gnaisse Belo Horizonte. Os plutonitos foram designados Granito Santa Luzia e Granito General Carneiro (Figura 6). Um terceiro plutonito, exibindo feições de campo semelhantes mas composição tonalítica a granodiorítica, foi identificado nas proximidades de Ibirité (Figura 6). Chemale Jr. et al. (1993) denominaram este corpo como Granodiorito Ibirité.

Os corpos granitóides posicionaram-se após a migmatização do Gnaisse Belo Horizonte, tendo sido afetados por pelo menos um evento deformacional anterior à tectônica principal do 
FIg. 6 MAPA GEOLOGGICO DA REGIĀO SETENTRIONAL DO QUADRILÁTERO FERRIFERO E COMPLEXOS DE BELO HORIZONTE E BONFIM*

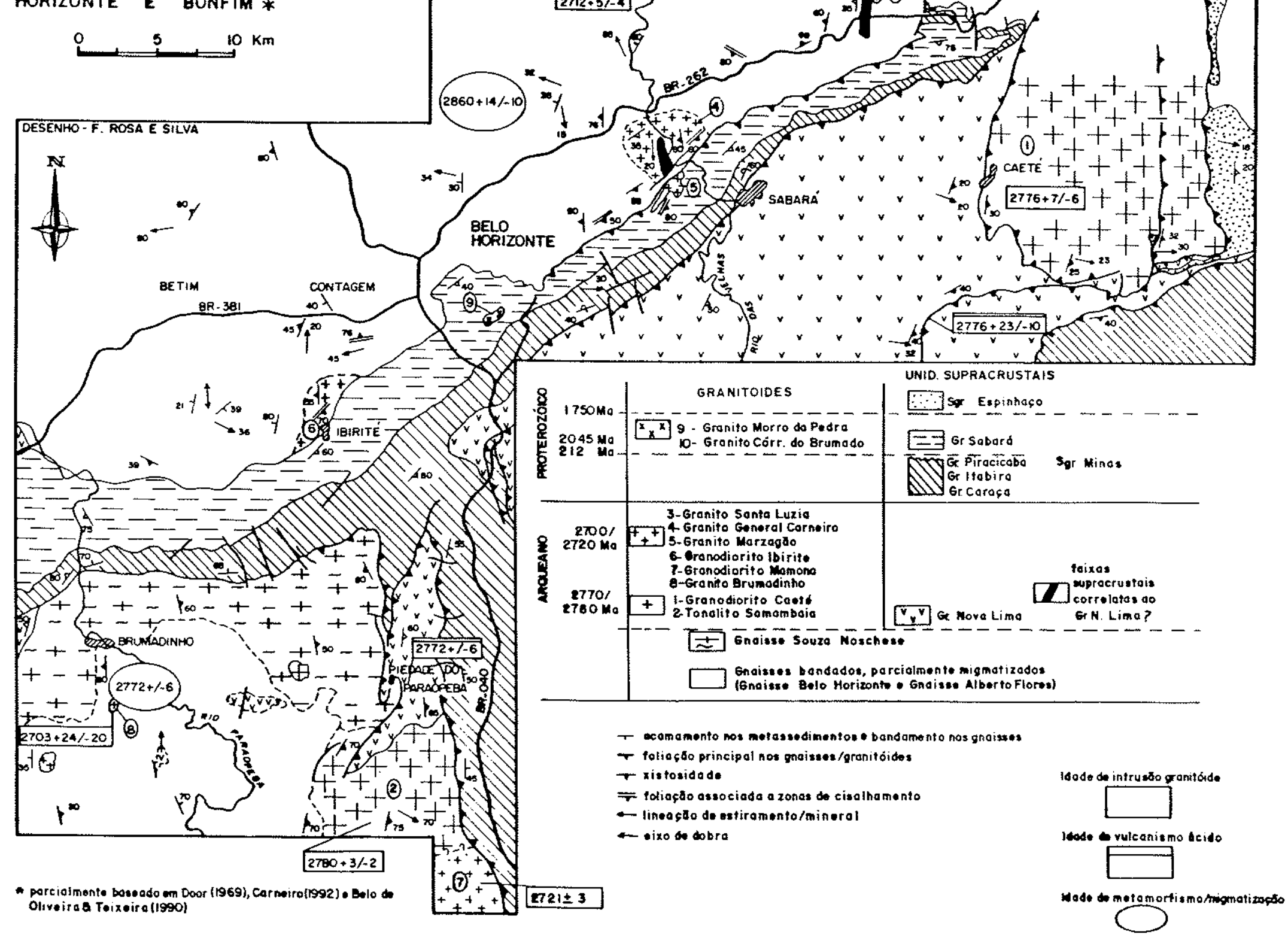


Supergrupo Minas. Portanto, presume-se que estejam associados à evolução arqueana do Complexo Belo Horizonte.

O Granito Santa Luzia ocorre próximo à cidade homônima (Figura 6). Embora sua exposição se resuma a uma pedreira, o mapa aerogeofísico sugere que tenha diâmetro mínimo de $3-4 \mathrm{~km}$. O granito possui aspecto muito homogêneo, caracterizado por apresentar feldspato róseo. com até $2 \mathrm{~cm}$ de dimensão do eixo maior, orientados segundo a foliação. A foliação é muito bem desenvolvida, mas não se observa qualquer bandamento.

O Granito General Carneiro pode ser observado em pedreiras e cortes de ferrovia, na área entre Belo Horizonte e Sabará (Figura 6). Suas dimensões são da mesma ordem das do Granito Santa Luzia. Destaca-se, igualmente, pelo aspecto homogêneo e por apresentar porções com mega-cristais de feldspato potássico. Embora esteja bastante foliado, ocorrem zonas com estrutura homófana, onde a rocha exibe textura porfirítica.

Um pouco a sul da área de ocorrência do Granito General Carneiro ocorre o chamado Granito-Gnaisse Marzagão (Herz 1970, Figura 6). Trata-se de um corpo intensamente cisalhado, ao qual se atribuiu caráter intrusivo no Grupo Sabará (Gair 1962). Relações de contato não foram observadas e admite-se a hipótese de um posicionamento tectônico.

O Granodiorito Ibirité é observado em pedreira situada junto à localidade de mesmo nome (Figura 6). Apresenta foliação muito bem desenvolvida e de aspecto milonítico, sendo cortado por veios granitóides de pequena espessura.

A presença de inclusões de rochas supracrustais, com dimensões de poucos centímetros a vários quilômetros, é uma feição característica dos complexos gnáissicos arqueanos (Condie 1981). No Complexo Belo Horizonte, ocorrem duas faixas vulcano-sedimentares com dimensões da ordem de $2-5 \mathrm{~km}$, orientadas segundo N-S e apresentando mergulhos elevados . Uma delas posiciona-se junto ao Rio das Velhas, a noroeste de Sabará (Figura 6). A maior parte da seqüência é constituida por anfibolitos, totalmente decompostos, associados a formação ferrifera, metacherte, muscovita xisto e grafita xisto. A formação ferrífera é composta por anfibólio, quartzo e óxidos de ferro. O Granito General Carneiro é, provavelmente, intrusivo nesta faixa, a qual é cortada por corpos pegmatíticos próximo ao contato com o granito.

A outra faixa de supracrustais, situada a leste da anterior (Figura 6), é constituída por quartzito, formação ferrífera a anfibólio e piroxênio, anfibólio xisto e rara rocha cálcio-silicática (Ferrari 1980, Motta et al. 1989). Door (1969) atribuiu este pacote ao Supergrupo Minas.

As duas faixas vulcano-sedimentares possuem características semelhantes, exibindo uma sucessão de litotipos usualmente encontrada nas seqüências arqueanas. Ademais. sua estruturação é discordante daquela do Supergrupo Minas. o que indica a idade mais antiga. Portanto, é provável que representem os remanescentes de um greenstone belt arqueano. 
Em termos estruturais, o Complexo Belo Horizonte registra evolução policíclica. $O$ Gnaisse Belo Horizonte exibe foliação bem desenvolvida, frequentemente de caráter milonitico. A orientação geral da foliação varia entre N-S e NNE-WSW, com mergulhos de $40^{\circ}$ a $60^{\circ}$ para W e WNW. Esta foliação pode paralelizar-se ao bandamento dos gnaisses ou, quando este se encontra dobrado, assumir posição plano-axial. As dobras exibidas pelo bandamento são apertadas a isoclinais, frequentemente redobradas de modo coaxial, com eixos em torno do meridiano. Por vezes, nas charneiras, observa-se foliação mais antiga parcialmente transposta pela foliação principal. $O$ desenvolvimento desta foliação principal parece ter sido algo precoce a sincrônico com a migmatização dos gnaisses. As bandas de leucossoma são concordantes ou cortam a foliação/bandamento, enquanto porções nebulíticas exibem "relíquias" da foliação.

O Granito Santa Luzia apresenta foliação com direção NW-SE e mergulhos moderados. menores que $30^{\circ}$, para SW. Localmente, a foliação mais proeminente do Gnaisse Belo Horizonte assume esta mesma orientação. Interessante constatar que, na porção centro-leste do Quadrilátero Ferrífero, as rochas do Supergrupo Rio das Velhas estão também orientadas segundo NW-SE no Sinclinal Vargem do Lima (Figura 5), sendo esta estruturação afetada pelas estruturas do Supergrupo Minas na área (C. A. Rosière, com. verbal). Ladeira \& Viveiros (1984) afirmam que a primeira fase de deformação do Supergrupo Rio das Velhas, de idade pré-Minas, apresenta vergência para NE. Portanto, o acervo estrutural do Granito Santa Luzia parece registrar um evento deformacional do Arqueano que também envolveu o Supergrupo Rio das Velhas.

A deformação principal do Supergrupo Minas está impressa nos gnaisses e corpos graníticos ao longo de uma faixa que acompanha a Serra do Curral. Manifesta-se pelo desenvolvimento de uma foliação de transposição de alto ângulo, orientada segundo NE-SW. Esta pode ocorrer em zonas de cisalhamento estreitas ou apresentar caráter mais pervasivo, reorientando totalmente as estruturas mais antigas.

\subsection{PETROQUIMICA}

\subsubsection{Gnaisse Belo Horizonte}

O estudo petrográfico do Gnaisse Belo Horizonte mostra uma relação plagioclásio/Kfeldspato bastante variável, resultando na presença de termos tonalíticos até graníticos, com 
expressiva predominância dos primeiros. Nos termos tonalíticos, o K-feldspato é muito subordinado e possui caráter intersticial, enquanto nas rochas granodioríticas a graníticas pode formar mega-cristais geralmente pertíticos e ricos em inclusões. O plagioclásio, em geral oligoclásio, está quase sempre saussuritizado e alguns cristais exibem zonamento. A biotita é sempre o mineral máfico principal, em média perfazendo 5 a $10 \%$ da rocha. Via de regra. apresenta alteração para clorita e/ou mica branca. Anfibólio (hornblenda) pode estar presente em algumas amostras, de forma muito secundária. Os accessórios mais comuns são titanita, epidoto, apatita e zircão. Allanita está presente nas rochas de composição granítica. Algumas amostras ainda preservam texturas de aspecto ígneo, em geral inequigranular hipidiomórfica a xenomórfica. Nas demais, a textura é granoblástica ou milonítica.

Foram efetuadas 10 análises quimicas completas, incluindo ETR, para o Gnaisse Belo Horizonte. Outras três análises de elementos maiores e menores provêm de Herz (1970). Um ponto essencial na discussão desses dados químicos é o fato de o Gnaisse Belo Horizonte ter sido afetado por, no mínimo, três eventos termais, conforme atestam os dados isotópicos a serem discutidos em outra seção deste trabalho. O evento mais antigo atingiu a anatexia, migmatizando os gnaisses em diversos níveis de intensidade. Desta forma, os dados químicos devem refletir, além da composição original, transformações advindas de processos metassomáticos. Como norma, amostraram-se exposições onde a migmatização mostrava-se incipiente, ou porções que pareciam mais preservadas deste processo. Para efeito de comparação, foram feitas análises do gnaisse migmatítico e de mobilizado félsico.

Os dados das análises químicas estão apresentados na tabela 4. As análises $n^{\circ} 1$ a 8 representam os gnaisses discretamente migmatizados ou sem evidência de migmatização. Sua composição química é trondhjemítica, enquanto os gnaisses migmatíticos (análises $n^{\circ} 9$ e 10 ) apresentam composição granítica (Figura 7).

Analisando os dados de elementos maiores para o Gnaisse Belo Horizonte (análises $\mathrm{n}^{\circ} 1$ a 8 , tabela 4) constata-se seu caráter peraluminoso. Apresenta teores elevados em $\mathrm{Na}_{2} \mathrm{O}$ (média de 5,2 ). Os teores em $\mathrm{Na}_{2} \mathrm{O}$ e $\mathrm{K}_{2} \mathrm{O}$ variam consideravelmente, de maneira que a razão $\mathrm{K}_{2} \mathrm{O} / \mathrm{Na}_{2} \mathrm{O}$ apresenta espectro amplo, entre 0,20 e 0,78, com média igual a 0,46. Os teores em $\mathrm{SiO}_{2}$ são relativamente elevados (média de 72,5\%). O CaO varia pouco, entre 1,5 e 2,3\%. No conjunto, esses valores aproximam-se daqueles atribuídos aos trondhjemitos por Barker (1979), quais sejam: $\mathrm{SiO}_{2}>68 \%, \mathrm{Fe}_{2} \mathrm{O}_{3}+\mathrm{MgO}<3,4 \%, \mathrm{Na}_{2} \mathrm{O}$ entre $4,0-5,5 \%$ e $\mathrm{K}_{2} \mathrm{O}<2 \%$.

Em relação aos elementos menores, pode-se destacar a ausência de anomalias de Sr e Ba e a forte anomalia negativa de $\mathrm{Nb}$ (Figura 8). As curvas de ETR (Figura 9) revelam acentuado empobrecimento em ETRP e anomalia negativa de Eu. O comportamento das ETRL é bastante constante para o conjunto de análises, o mesmo não ocorrendo com as ETRP. Enquanto a razão $(\mathrm{La} / \mathrm{Sm})_{N}$ mantem-se entre 3,8 e 5,7 , a razão $(\mathrm{Gd} / \mathrm{Lu})_{N}$ varia de 2,5 a 6,2 . 
Tabela 4: Composições quimicas do Gnaisse Belo Horizonte (I a 8), gnaisse migmatítico (9 e 10), mobilizado migmatitico (11) e migmatito nebulitico (12).

\begin{tabular}{|c|c|c|c|c|c|c|c|c|c|c|c|c|}
\hline $\begin{array}{l}\text { Número } \\
\text { Amostra } \\
\end{array}$ & $\begin{array}{c}1^{\star} \\
.653 \\
\end{array}$ & $\begin{array}{c}2^{\star} \\
\mathrm{Ha}-140\end{array}$ & $\begin{array}{c}3 \\
N-38 \Lambda \\
\end{array}$ & $\begin{array}{c}4 \\
V-37 A \\
\end{array}$ & $\begin{array}{c}5 \\
V-69 \\
\end{array}$ & $\begin{array}{c}6 \\
\mathrm{~V}-71\end{array}$ & $\begin{array}{c}7 \\
N-67 \\
\end{array}$ & $\begin{array}{c}8 \\
N-59 \\
\end{array}$ & $\begin{array}{c}9 \\
\mathrm{~V}-33 \mathrm{~A} \\
\end{array}$ & $\begin{array}{c}10^{*} \\
11 \mathrm{a}-16 \mathrm{a}\end{array}$ & $\begin{array}{c}11 \\
V-33 B\end{array}$ & $\begin{array}{c}12 \\
\mathrm{~N}-68 \\
\end{array}$ \\
\hline $\mathrm{SiO}_{2}$ & 73.6 & 73.5 & 73,4 & 72.4 & 72,1 & 70,2 & 69.8 & 69,6 & 70,7 & 69,4 & 73,4 & 73,5 \\
\hline $\mathrm{HiO}_{2}^{2}$ & 0,19 & 0,19 & $0,2 !$ & 0,29 & 0,19 & 0,35 & 0,30 & 0,40 & 0,43 & 0,48 & 0,10 & 0.19 \\
\hline $\mathrm{Al}_{2} \mathrm{O}_{3}$ & 14,8 & 14,9 & 14,5 & 13,9 & 14,1 & 15,7 & 15,7 & 15,5 & 14,1 & 14,6 & 11,1 & 11,4 \\
\hline $\mathrm{Fe}_{2} \mathrm{O}_{3}$ & 0,10 & 0,50 & 0,37 & 1,20 & 0,36 & 0,43 & 0,57 & 0,57 & 1,70 & 0,80 & 0,68 & 0,36 \\
\hline $\mathrm{FeO}^{2}$ & 1,4 & 1,2 & $\uparrow, 2$ & 1,1 & 1,18 & 2,3 & 1,75 & 1,8 & 1,1 & 2,0 & 0,21 & 1,18 \\
\hline $\mathrm{MnO}$ & 0,04 & 0,05 & 0,02 & 0,04 & 0,02 & 0,03 & 0,03 & 0,03 & 0,04 & 0,08 & 0,01 & 0,01 \\
\hline $\mathrm{MgO}$ & 0,38 & 0,44 & 0.39 & 0,74 & 0,51 & 0,88 & 0,76 & 1,13 & 0,68 & 0,68 & 0,16 & 0,18 \\
\hline $\mathrm{CaO}$ & 1.5 & 1,7 & 1,8 & 2,3 & 1,6 & 2,0 & 1,5 & 2,2 & 1,7 & 2,1 & 1,1 & 0,72 \\
\hline $\mathrm{Na}_{2} \mathrm{O}$ & 5.1 & 4.9 & 4,0 & 4,5 & 5,4 & 6,4 & 6,6 & 4,7 & 3,3 & 3,2 & 2,6 & 3,2 \\
\hline $\mathrm{K}_{2} \mathrm{O}$ & 2.3 & 2.2 & 3,1 & 2,2 & 2,5 & 1,4 & 1,4 & 2,9 & 5,2 & 5,1 & 5,1 & 5,2 \\
\hline $\mathrm{P}_{2} \mathrm{O}_{5}$ & 0,04 & 0,08 & 0,06 & 0,10 & 0,07 & 0,05 & 0,06 & 0,12 & 0,14 & 0,26 & 0,03 & 0,05 \\
\hline $\mathrm{H}_{2}^{2} \mathrm{O}^{7}$ & 0,52 & 0.54 & 0,69 & - & 0,53 & 0,60 & 0.97 & 0,89 & 0,50 & 0,58 & 0,49 & 0,47 \\
\hline $\mathrm{CF}_{2}$ & - & 0,06 & 0,10 & 0.90 & $\cdot$ & - & - & - & 0,20 & 0,14 & - & - \\
\hline $\mathrm{F}$ & - & - & 310 & 700 & - & - & - & - & 670 & 600 & - & - \\
\hline $\mathrm{S}$ & - & - & $<50$ & - & - & $*$ & - & . & 100 & - & - & - \\
\hline $\mathrm{Cl}$ & - & - & 64 & 22 & - & - & . & . & 100 & - & - & - \\
\hline $\mathrm{Cr}$ & 3 & 7 & $<20$ & - & - & - & - & - & $<20$ & 18 & - & - \\
\hline $\mathrm{Ni}$ & 22 & 5 & $<20$ & " & - & - & - & - & $<20$ & 8 & - & - \\
\hline $\mathrm{Co}$ & 2 & 3 & $<5$ & . & 4 & 52 & 6 & 67 & 6 & 8 & 4 & 19 \\
\hline $\mathrm{Sc}$ & 4 & 6 & $<5$ & - & - & - & - & - & 5 & 7 & - & - \\
\hline V & 12 & 26 & 78 & 29 & $<10$ & 17 & 13 & 25 & 122 & $2 I$ & $<10$ & $<10$ \\
\hline $\mathrm{Li}$ & - & - & 17 & - & - & - & - & - & 17 & - & - & - \\
\hline $\mathrm{Cu}$ & - & - & 6 & 5 & $<5$ & $<5$ & $<5$ & $<5$ & 10 & 11 & $<5$ & $<5$ \\
\hline $\mathrm{Pb}$ & 19 & 32 & 8 & 37 & 54 & 54 & 40 & 49 & 12 & 15 & 46 & 61 \\
\hline $\mathrm{Zn}$ & - & - & 43 & 76 & 36 & 57 & 66 & 39 & 56 & - & 12 & 15 \\
\hline $\mathrm{Rb}$ & - & - & 98 & 110 & - & - & - & - & 150 & - & - & - \\
\hline $\mathrm{Ba}$ & 800 & 440 & 820 & 600 & 1427 & 1055 & 1120 & 2175 & 970 & 1600 & 1624 & 2038 \\
\hline $\mathrm{Sr}$ & 230 & 240 & 290 & 490 & 305 & 317 & 414 & 365 & 330 & 380 & 300 & 281 \\
\hline $\mathrm{Nb}$ & 22 & 13 & $<8$ & - & - & - & - & - & 18 & 27 & - & - \\
\hline $\mathrm{Zr}$ & 140 & 106 & 140 & 250 & - & - & - & - & 220 & 310 & - & - \\
\hline Y & 15 & 13 & 17 & 24 & 6 & 7 & 7 & 18 & 47 & 66 & 3 & 5 \\
\hline La & & & 24,13 & 24,93 & 23,7 & 19,8 & 21,3 & 23,9 & 83,5 & & 35,3 & 17,4 \\
\hline $\mathrm{Ce}$ & & & 55,21 & 52,73 & 44,9 & 39,3 & 40.1 & 59,7 & 178,5 & & 65,6 & 36,6 \\
\hline $\mathrm{Nd}$ & & & 18,03 & 18,78 & 16,0 & 14,3 & 15,6 & 21,0 & 68,93 & & 22,6 & 12,5 \\
\hline $\mathrm{Sm}$ & & & 4,034 & 3,441 & 2,6 & 2,5 & 2,7 & 4,0 & 14,63 & & 3,1 & 2,0 \\
\hline Eu & & & 0,506 & 0,558 & 0,64 & 0,59 & 0.65 & 0,88 & 1,448 & & 1,1 & 0,50 \\
\hline $\mathrm{Gd}$ & & & 2,363 & 2,342 & 2,4 & 2,5 & 2,5 & 3,9 & 8,873 & & 2,0 & 2,0 \\
\hline Dy & & & 2,055 & 1,78 & 1,1 & 1,4 & 1,6 & 3,3 & 7,707 & & 0,79 & 1,0 \\
\hline Ho & & & 0,405 & 0,349 & 0,20 & 0,24 & 0,25 & 0,64 & 1,437 & & 0,11 & 0,17 \\
\hline $\mathrm{Er}$ & & & 1,073 & 0,915 & 0,59 & 0,69 & 0,64 & 1,8 & 3,361 & & 0,31 & 0,50 \\
\hline $\mathrm{Yb}$ & & & 0,896 & 0,626 & 0,51 & 0,57 & 0.44 & 1,5 & 2,021 & & 0,33 & 0,46 \\
\hline $\mathrm{Lu}$ & & & 0,117 & 0,10 & 0,07 & 0.08 & 0,05 & 0,18 & 0.228 & & 0,05 & 0,07 \\
\hline $\mathrm{La}_{\mathrm{n}} / \mathrm{Lu}_{\mathrm{n}}$ & & & 21,41 & 25,88 & 35,14 & 25,69 & 44,22 & 13.78 & 38,02 & & 73,28 & 25,80 \\
\hline $\mathrm{La}_{n} / \mathrm{Sm}_{\mathrm{n}}$ & & & 3,766 & 4,561 & 5,739 & 4,986 & 4,967 & 3,762 & 3,593 & & 7,169 & 5,478 \\
\hline$E u_{n}^{\prime \prime} / E u^{*}$ & & & 0,462 & 0,569 & 0,771 & 0,714 & 0,753 & 0,673 & 0,361 & & 1,267 & 0,756 \\
\hline $\mathrm{Eu}_{\mathrm{n}} / \mathrm{Sm_{ \textrm {n } }}$ & & & 0,333 & 0,430 & 0,653 & 0,624 & 0.639 & 0.584 & 0,263 & & 0,942 & 0,664 \\
\hline$G d_{n} / L u_{n}$ & & & 2,51 & 2.91 & 4,26 & 1,98 & 6,21 & 2,69 & 4,839 & & 4,971 & 3,551 \\
\hline $\begin{array}{l}\text { ETRL/ } \\
\text { ETRP }\end{array}$ & & & 14,75 & 16,43 & 18,04 & 13,96 & 14,66 & 9,67 & 14,69 & & 35,57 & 16,43 \\
\hline
\end{tabular}




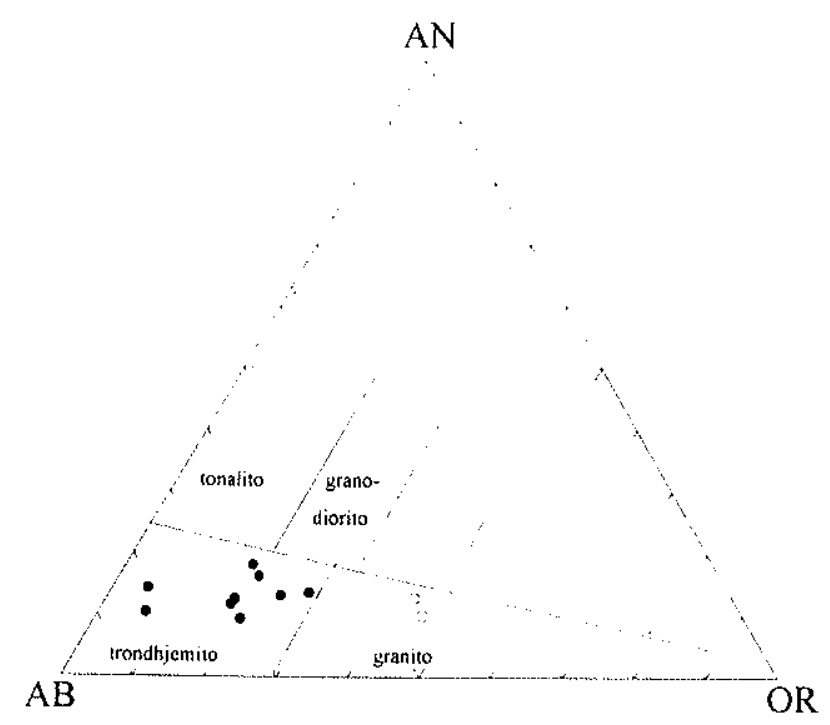

Figura 7: Classificação do Gnaisse Belo Horizonte (círculos preenchidos) segundo o diagrama Ab-An-Or (normativo) de O'Connor (1965). Circulos vazios representam análises do gnaisse migmatítico.

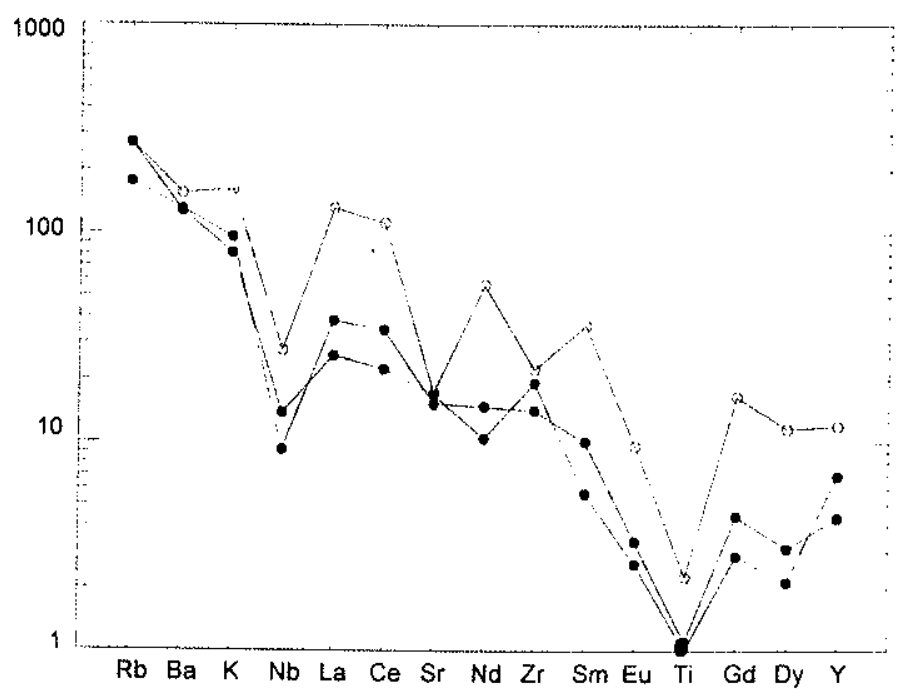

Figura 8: Diagrama de variação de elementos-traço, normalizados para o manto primitivo, para o Gnaisse Belo Horizonte. A curva com círculos vazios representa o gnaisse migmatítico.

As análises do gnaisse migmatítico (análises $n^{\circ} 9$ e 10 , tabela 4) mostram enriquecimento em $\mathrm{K}_{2} \mathrm{O}$ e teores mais baixos em $\mathrm{Na}_{2} \mathrm{O}$, sendo a razão $\mathrm{K}_{2} \mathrm{O} / \mathrm{Na}_{2} \mathrm{O}$ maior que 1 . A curva de ETR disponivel para uma das análises (análise $n^{\circ} 9$, tabela 3), quando comparada com as curvas do gnaisse pouco migmatizado, exibe enriquecimento generalizado nas ETR leves e pesadas e 
anomalia negativa de Eu mais acentuada (Figura 9), mas mantendo forma semelhante. Outro fator distintivo é o acentuado empobrecimento em $\mathrm{Sr}$ em relação a elementos de similar "compatibilidade", presente apenas no gnaisse migmatítico (Figura 8). A anomalia negativa de Eu mais acentuada, juntamente com a de $\mathrm{Sr}$, podem ser explicadas como uma função do maior grau de separação líquido-plagioclásio, que ocorre quando a fusão se separa de um resíduo rico em plagioclásio, ou nos estágios finais da cristalização fracionada (e.g. Hill et al. 1992).

Uma hipótese para explicar a composição química do gnaisse migmatítico é que os resultados das análises tenham sido influenciados pela proporção de material neo-formado (leucossoma) presente nas amostras, já que sua separação não foi possível durante a amostragem. Alternativamente, as rochas migmatizadas poderiam derivar de um protólito mais evoluído, de composição granítica.

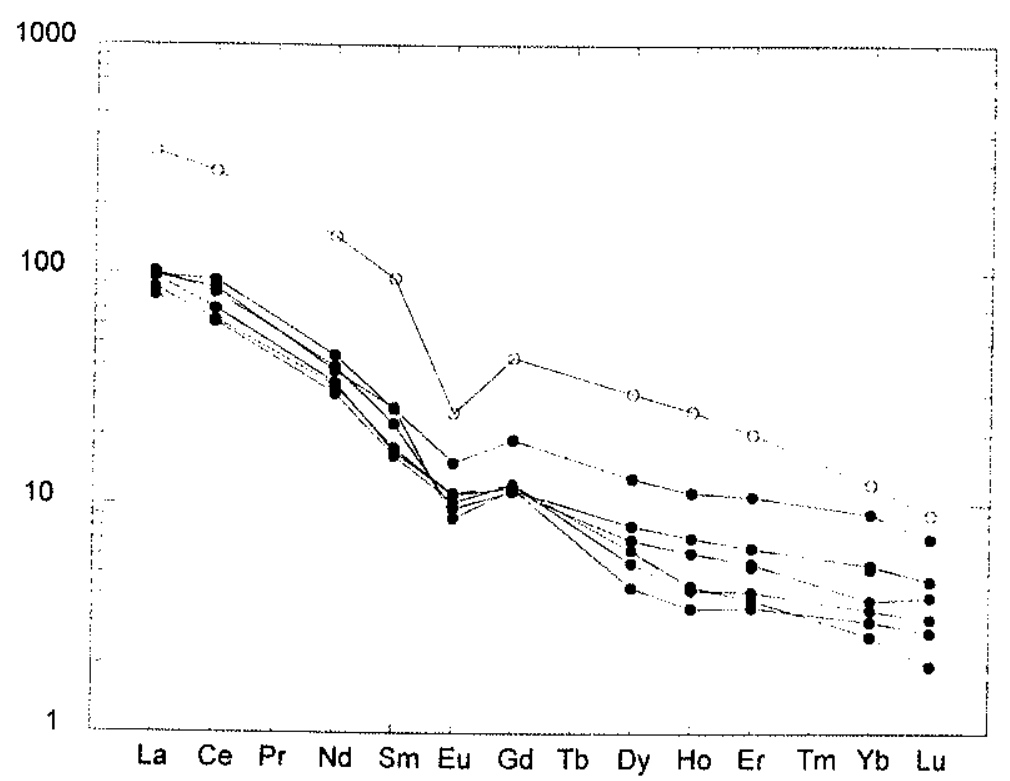

Figura 9: Curvas de ETR, normalizadas para condritos, para o Gnaisse Belo Horizonte. A curva com cïrculos vazios representa um gnaisse migmatítico. Valores de normalização de Evensen et al. (1978).

As análises $n^{\circ} 11$ e 12 (Tabela 4) correspondem a um mobilizado migmatítico e a uma porção nebulítica. Os dados, em relação aos elementos maiores. são compatíveis com um processo de fusão parcial dos gnaisses. Constata-se enriquecimento em $\mathrm{K}_{2} \mathrm{O}$, com $\mathrm{K}_{2} \mathrm{O} / \mathrm{Na}_{2} \mathrm{O}$ maior que 1, e empobrecimento em $\mathrm{Al}_{2} \mathrm{O}_{3} \mathrm{e} \mathrm{FeO}_{(\mathrm{t})}+\mathrm{MgO}$. A curva de $\mathrm{ETR}$ do mobilizado exibe anomalia positiva de Eu. Este resultado é exposto na figura 10, comparado com a curva do 
gnaisse migmatítico do mesmo afloramento onde foi amostrado o mobilizado. O empobrecimento mais acentuado em ETRP é compatível com a fusão de material granítico já empobrecido nestes elementos. Uma possível explicação para a anomalia positiva de Eu no mobilizado seria uma contribuição advinda da fusão simultânea de rochas máficas enriquecidas neste elemento. De fato, ocorrem na mesma exposição corpos anfibolíticos muito afetados pela migmatização.

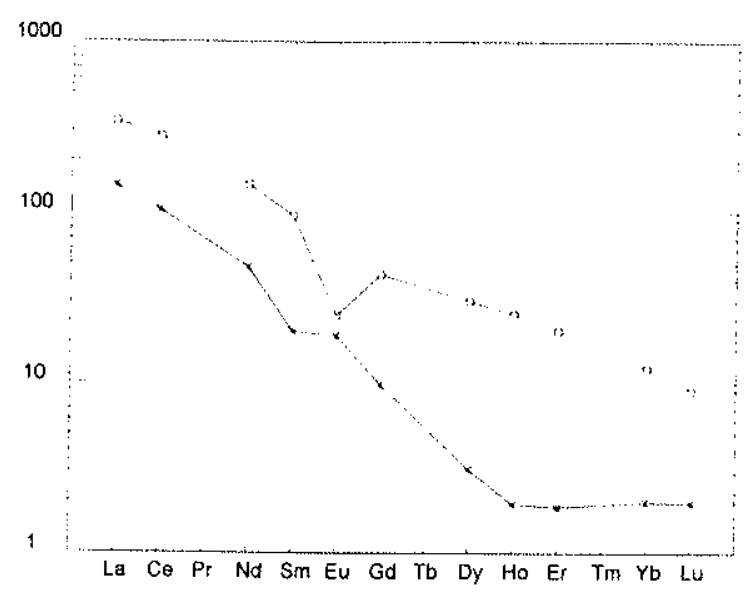

Figura 10: Curvas de ETR, normalizadas para condritos, do gnaisse migmatítico (circulos) e mobilizado félsico (asteriscos) do mesmo afloramento. Valôres de normalização de Evensen et al. (1978).

A média das análises de elementos maiores do Gnaisse Belo Horizonte aproxima-se dos valores de TTG arqueanos típicos (Tabela 5). Condie (1981) apresenta composições químicas médias para tonalitos e trondhjemitos arqueanos, divididos segundo a classificação de Barker (1979) em alto $\mathrm{Al}_{2} \mathrm{O}_{3}$ e baixo $\mathrm{Al}_{2} \mathrm{O}_{3}$. A figura 11 exibe as curvas de ETR para as duas classes, comparado com a curva média para o Gnaisse Belo Horizonte. Constata-se marcante semelhança entre esta última e a curva dos tonalitos e trondhjemitos de alto $\mathrm{Al}_{2} \mathrm{O}_{3}$, exceto pela anomalia negativa de Eu presente no Gnaisse Belo Horizonte. Entretanto, em termos de elementos maiores, as amostras do gnaisse posicionam-se nas duas classes de tronhdjemitos (alto e baixo $\left.\mathrm{Al}_{2} \mathrm{O}_{3}\right)$.

Outra comparação é feita com a curva média de ETR para o Gnaisse Alberto Flores (Figura 11), que representa a crosta continental mais antiga do Complexo Bonfim (Carneiro 1992). A anomalia de Eu é mais acentuada no Gnaisse Alberto Flores que no Gnaisse Belo Horizonte. Carneiro (1992) constatou semelhanças entre o Gnaisse Alberto Flores e alguns gnaisses arqueanos do Ancient Gneiss Complex (Swazilândia) e de Wyoming (EUA). 
Tabela 5: Composição média do Gnaisse Belo Horizonte comparado com a composição média de TTG arquenos.

\begin{tabular}{|c|cc|c|c|c|c|}
\cline { 2 - 7 } \multicolumn{1}{c|}{} & Gnaisse Belo Horizonte & \multicolumn{2}{c|}{} \\
\hline Elem. & média & $\mathrm{CV}$ & $\begin{array}{c}\text { TTG } \\
\text { Arqueano* }\end{array}$ & Norma & $\begin{array}{c}\text { Gnaisse Belo } \\
\text { Horizonte }\end{array}$ & $\begin{array}{c}\text { TTG } \\
\text { Arqueano }\end{array}$ \\
\hline \hline $\mathrm{SiO}_{2}$ & 71.83 & 2.9 & 70.68 & $\mathrm{Q}$ & 28.97 & 26.67 \\
$\mathrm{TiO}_{2}$ & 0.27 & 30.1 & 0.25 & $\mathrm{Or}$ & 13.24 & 13.36 \\
$\mathrm{Al}_{2} \mathrm{O}_{3}$ & 14.89 & 6.9 & 15.11 & $\mathrm{Ab}$ & 42.90 & 39.35 \\
$\mathrm{Fe}_{2} \mathrm{O}_{3}$ & 0.51 & 60.0 & 0.88 & $\mathrm{An}$ & 7.92 & 12.94 \\
$\mathrm{FeO}$ & 1.52 & 29.9 & 1.75 & $\mathrm{C}$ & 0.96 & 0.27 \\
$\mathrm{MnO}$ & 0.03 & 35.4 & 0.04 & $\mathrm{Hy}$ & 3.45 & 5.06 \\
$\mathrm{MgO}$ & 0.65 & 39.1 & 1.17 & $\mathrm{Mt}$ & 0.72 & 1.18 \\
$\mathrm{CaO}$ & 1.83 & 17.3 & 2.78 & 11 & 0.49 & 0.47 \\
$\mathrm{Na}{ }_{2} \mathrm{O}$ & 5.20 & 18.3 & 4.65 & Ap & 0.16 & 0.30 \\
$\mathrm{~K}_{2} \mathrm{O}$ & 2.25 & 54.5 & 2.26 & $\mathrm{Cc}$ & 0.18 & - \\
$\mathrm{P}_{2} \mathrm{O}_{5}$ & 0.07 & 28.6 & 0.13 & & & \\
*: média de 494 análises, Martin (1990): CV: coeficiente de variação &
\end{tabular}

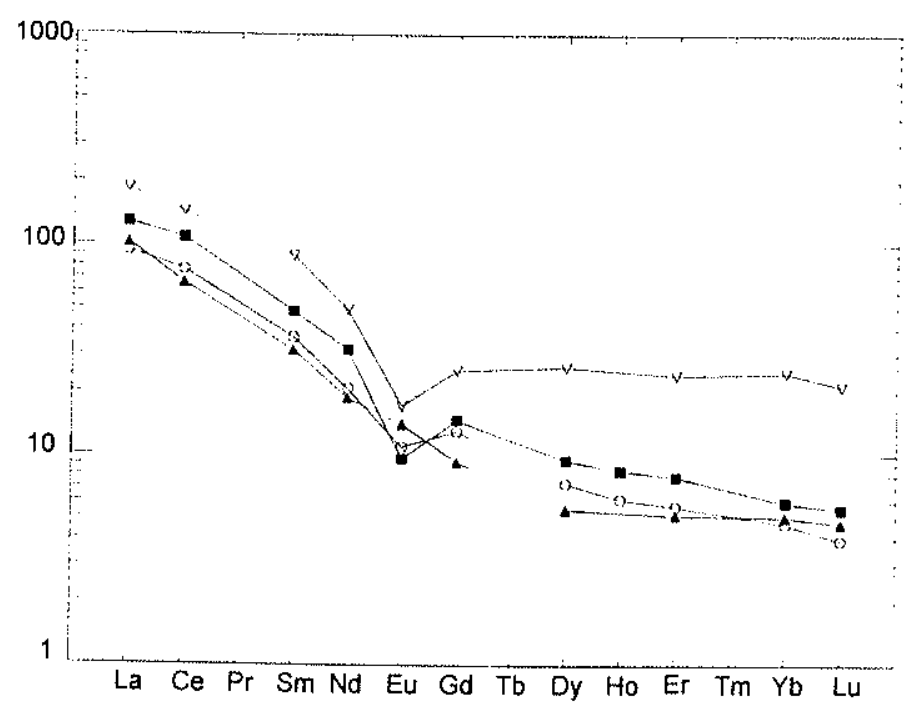

Figura 11: Diagrama comparativo entre a curva média de ETR para o Gnaisse Belo Horizonte (circulos vazios), as curvas médias para tonalitos e trondhjemitos arqueanos de alto $\mathrm{Al}_{2} \mathrm{O}_{3}$ (triângulos preenchidos) e baixo $\mathrm{Al}_{2} \mathrm{O}_{3}$ (triângulos vazios invertidos) e para o Gnaisse Alberto Flores (quadrados preenchidos). Curvas para tonalitos e trondhjemitos arqueanos segundo Condie (1981) e para o Gnaisse Alberto Flores segundo Carneiro (1992). Curvas normalizadas para condritos segundo os valores de normalização de Evensen et al. (1978). 
Em um diagrama $(\mathrm{Yb})_{\mathrm{N}} \mathrm{x}(\mathrm{La} / \mathrm{Yb})_{\mathrm{N}}$ (Martin 1987), a maior parte da análises do Gnaisse Belo Horizonte posiciona-se no campo dos TTG arqueanos, exceto por duas delas, ai incluindo a análise do gnaisse migmatítico (Figura 12). Estas duas amostras apresentam menor fracionamento de ETR e conseqüente maior conteúdo relativo em $\mathrm{Yb}$, mais típico dos granitóides pós-arqueanos.

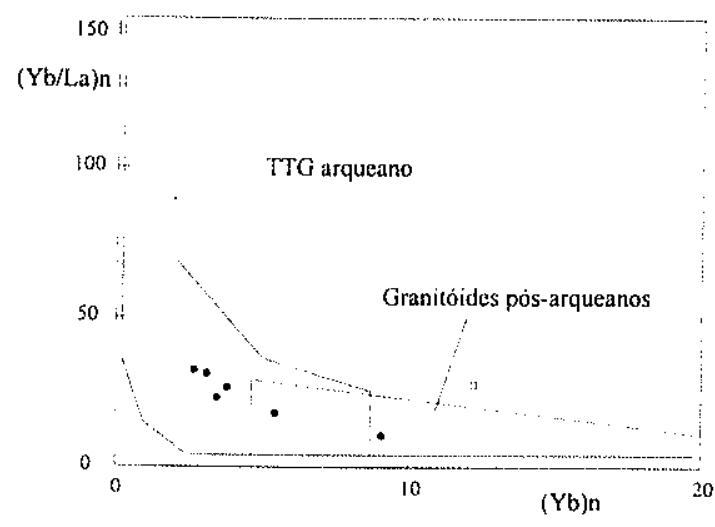

Figura 12: Diagrama $(Y b)_{\mathrm{N}} x(L a / Y b)_{\mathrm{N}}$ (Martin 1987) mostrando a variação no conteúdo em ETR no tempo geológico. Círculos preenchidos representam análises do Gnaisse Belo Horizonte e circulo vazio uma análise do gnaisse migmatítico.

Em conclusão, a despeito das transformações sofridas em função de eventos de retrabalhamento, a assinatura geoquímica do Gnaisse Belo Horizonte ainda reflete sua identificação com as suítes TTG do Arqueano. A gênese dessas suítes tem sido objeto de considerável debate, especialmente por estar relacionada à própria origem primária da crosta continental. Segundo Tarney \& Saunders (1990), é geralmente aceito que certas características geoquímicas das suítes TTG arqueanas (fracionamento acentuado dos ETR e empobrecimento em ETRP; marcante anomalia de $\mathrm{Nb}$; ausência de anomalias ou anomalias positivas de $\mathrm{Eu}, \mathrm{Sr}$ e $\mathrm{Ba}$; baixos teores de $\mathrm{Th}, \mathrm{U}$ e $\mathrm{Rb}$; razão $\mathrm{K} / \mathrm{Rb}$ elevada) são explicadas, melhormente, pela fusão parcial, em profundidades rasas no manto, de uma fonte anfibolítica ou granada-anfibolítica. Por sua vez. esse processo estaria relacionado à subducção e fusão de crosta oceânica (e.g. Condie 1981, Martin 1987. Leake 1990, Tarney \& Saunders 1990). 


\subsubsection{Plutonitos Granitóides (Granito Santa Luzia, Granito General Carneiro, Granito Marzagão e Granodiorito Ibirité)}

O Granito Santa Luzia encontra-se bastante deformado, exibindo textura granoblástica. $\mathrm{O}$ K-feldspato ocorre em proporção mais elevada que o plagioclásio, formando megacristais de cor rósea. Quartzo e biotita completam a mineralogia essencial. O plagioclásio apresenta-se profundamente saussuritizado. Titanita é um accessório frequente, ocorrendo como mineral primário e também como produto da cloritização da biotita. Deve-se ressaltar a presença de allanita, que chega a formar cristais euédricos com até $3 \mathrm{~mm}$ de dimensão.

O Granito General Carneiro possui cor cinza-clara e é constituído por quartzo, K-feldspato e plagioclásio em proporções semelhantes. O mineral máfico é biotita, perfazendo menos que $5 \%$ da rocha. $\mathrm{O} \mathrm{K}$-feldspato pode formar megacristais de ortoclásio, pertíticos e ricos em inclusões, o que confere à rocha um caráter porfirítico. Ocorre também como grãos menores e mais límpidos de microclina, intercrescidos na matriz. Estes cristais sofreram alguma recristalização, tendendo a formar bandas de textura granoblástica. A biotita apresenta-se quase totalmente alterada para mica branca e clorita. Este material micáceo, acrescido daquele proveniente da alteração do plagioclásio, orienta-se em faixas definindo a foliação. Assinala-se a presença de granada como mineral accessório, bastante rara.

Os dois corpos intrusivos em causa são granitos cálcio-alcalinos, ricos em potássio e ligeiramente peraluminosos (Tabela 6). O Granito Santa Luzia possui conteúdo em $\mathrm{SiO}_{2}(68 \%)$ consideravelmente menor que o do Granito General Carneiro (74\%), ao contrário do que acontece com o conteúdo em $\mathrm{FeO}_{(\mathrm{t})}+\mathrm{MgO}$, mais elevado no primeiro. Valores de $\mathrm{CaO}$ são mais elevados para o Granito Santa Luzia, como também as razões $\mathrm{K}_{2} \mathrm{O} / \mathrm{Na}_{2} \mathrm{O}$ (1,9 no Granito Santa Luzia e 1,1-1,4 no Granito General Carneiro).

Os teores de Rb são maiores para o Granito General Carneiro, mas o oposto acontece em relação ao Sr, com teores em torno de $500 \mathrm{ppm}$ no Granito Santa Luzia e $150 \mathrm{ppm}$ no Granito General Carneiro. Os teores de Ba são, igualmente, bem mais elevados no Granito Santa Luzia. A despeito destas diferenças, em um diagrama normalizado de variação de elementos-traços, as curvas dos dois corpos são semelhantes (Figura 13). Estas exibem característica depressão em Sr, além de $\mathrm{Nb}$ e $\mathrm{Ti}$. A depressão em $\mathrm{Nb}$ e $\mathrm{Ti}$ é, proporcionalmente, bem mais pronunciada no Granito Santa Luzia.

As curvas de ETR dos dois granitos são distintas (Figura 14a). O Granito Santa Luzia é mais enriquecido em ETR e apresenta fracionamento acentuado, com $(\mathrm{La} / \mathrm{Lu})_{\mathrm{N}}=25-30$. O fracionamento no Granito General Carneiro é bem menos acentuado, exibindo $(\mathrm{La} / \mathrm{Lu})_{\mathrm{N}}=5-9$. A anomalia de Eu difere pouco de um corpo para outro. Estas curvas, especialmente do Granito 
Tabela 6: Composições quimicas do Granito Santa Luzia (1 e 2), Granito General Carneiro (3 e 4), Granito Marzagão (5) e Granodiorito Ibirité (6).

\begin{tabular}{|c|c|c|c|c|c|c|}
\hline $\begin{array}{l}\text { Número } \\
\text { Amostra }\end{array}$ & $\begin{array}{c}1 \\
\mathrm{~N}-57 \mathrm{~A} \\
\end{array}$ & $\begin{array}{c}2 \\
N-57 B \\
\end{array}$ & $\begin{array}{c}3 \\
N-41 \\
\end{array}$ & $\begin{array}{c}4 \\
N .42 \\
\end{array}$ & $\begin{array}{c}5 \\
\mathrm{JG}-105^{*} \\
\end{array}$ & $\begin{array}{c}6 \\
N-39 \\
\end{array}$ \\
\hline $\begin{array}{c}\mathrm{SiO}_{2} \\
\mathrm{TiO}_{2} \\
\mathrm{Al}_{2} \mathrm{O}_{3} \\
\mathrm{Fe}_{2} \mathrm{O}_{3} \\
\mathrm{FeO} \\
\mathrm{MnO} \\
\mathrm{MgO} \\
\mathrm{CaO} \\
\mathrm{Na}_{2} \mathrm{O} \\
\mathrm{K}_{2} \mathrm{O} \\
\mathrm{P}_{2} \mathrm{O}_{5} \\
\mathrm{H}_{2} \mathrm{O}^{+} \\
\mathrm{CO}_{2} \\
\mathrm{PF}^{2}\end{array}$ & $\begin{array}{l}67,8 \\
0,42 \\
15,2 \\
1,80 \\
1,40 \\
0,06 \\
1,00 \\
1,7 \\
3,1 \\
6,0 \\
0,18 \\
0,83 \\
0,25\end{array}$ & $\begin{array}{c}68,0 \\
0,47 \\
14,8 \\
1,40 \\
1,50 \\
0,05 \\
1,00 \\
1,9 \\
3,1 \\
5,9 \\
0,23 \\
* \\
* \\
1,33 \\
\end{array}$ & $\begin{array}{c}74,3 \\
0,18 \\
13,4 \\
0,61 \\
0,89 \\
0,05 \\
0,47 \\
0,98 \\
3.2 \\
4,6 \\
0,08 \\
- \\
- \\
1.02 \\
\end{array}$ & $\begin{array}{c}74,0 \\
0,23 \\
13,9 \\
0,61 \\
0,98 \\
0,04 \\
0,41 \\
1,10 \\
3,7 \\
4,2 \\
0,09 \\
0,48 \\
0,15\end{array}$ & $\begin{array}{c}72.2 \\
0,08 \\
16,0 \\
0,30 \\
0,88 \\
0,02 \\
0,34 \\
0,62 \\
3.3 \\
5,2 \\
0,12 \\
0,84 \\
-\end{array}$ & $\begin{array}{c}75,7 \\
0,19 \\
12,6 \\
0,39 \\
1,0 \\
0,04 \\
0,56 \\
1,5 \\
4,0 \\
2,6 \\
0,05 \\
- \\
- \\
1,10 \\
\end{array}$ \\
\hline $\begin{array}{c}\mathrm{F} \\
\mathrm{S} \\
\mathrm{Cl} \\
\mathrm{Cr} \\
\mathrm{Ni} \\
\mathrm{Co} \\
\mathrm{Sc} \\
\mathrm{V} \\
\mathrm{Li} \\
\mathrm{Cu} \\
\mathrm{Pb} \\
\mathrm{Zn} \\
\mathrm{Rb} \\
\mathrm{Ba} \\
\mathrm{Sr} \\
\mathrm{Nb} \\
\mathrm{Zr} \\
\mathrm{Y} \\
\end{array}$ & $\begin{array}{c}700 \\
90 \\
64 \\
<20 \\
<20 \\
7 \\
12 \\
156 \\
22 \\
9 \\
12 \\
46 \\
180 \\
1340 \\
520 \\
11 \\
250 \\
74 \\
\end{array}$ & $\begin{array}{c}780 \\
130 \\
54 \\
- \\
- \\
- \\
- \\
34 \\
- \\
12 \\
47 \\
48 \\
180 \\
1330 \\
500 \\
18 \\
490 \\
110 \\
\end{array}$ & $\begin{array}{c}680 \\
<50 \\
26 \\
\cdot \\
- \\
\cdot \\
- \\
15 \\
- \\
4 \\
93 \\
48 \\
270 \\
570 \\
150 \\
16 \\
200 \\
81 \\
\end{array}$ & $\begin{array}{c}800 \\
<50 \\
33 \\
<20 \\
<20 \\
- \\
- \\
100 \\
78 \\
38 \\
23 \\
56 \\
250 \\
530 \\
130 \\
15 \\
150 \\
49 \\
\end{array}$ & $\begin{array}{c}- \\
- \\
- \\
4 \\
2 \\
1 \\
4 \\
3 \\
- \\
1 \\
52 \\
- \\
- \\
560 \\
100 \\
11 \\
53 \\
7 \\
\end{array}$ & $\begin{array}{c}510 \\
<50 \\
20 \\
- \\
- \\
- \\
- \\
16 \\
- \\
11 \\
47 \\
44 \\
150 \\
800 \\
320 \\
9 \\
190 \\
27 \\
\end{array}$ \\
\hline $\begin{array}{l}\mathrm{La} \\
\mathrm{Ce} \\
\mathrm{Nd} \\
\mathrm{Sm} \\
\mathrm{Eu} \\
\mathrm{Gd} \\
\mathrm{Dy} \\
\mathrm{Ho} \\
\mathrm{Er} \\
\mathrm{Yb} \\
\mathrm{Lu}\end{array}$ & $\begin{array}{l}105,9 \\
218,0 \\
83,97 \\
18,13 \\
1,783 \\
11,01 \\
10,94 \\
2,15 \\
5,642 \\
4,280 \\
0.461 \\
\end{array}$ & $\begin{array}{c}117,8 \\
244.5 \\
90,75 \\
17,08 \\
1,934 \\
11,67 \\
10,95 \\
2,10 \\
5,207 \\
3,589 \\
0,401 \\
\end{array}$ & $\begin{array}{l}17,34 \\
45,05 \\
19,67 \\
4,584 \\
0,464 \\
3,671 \\
4,474 \\
0,927 \\
2,661 \\
2,753 \\
0,374 \\
\end{array}$ & $\begin{array}{c}30,29 \\
73,77 \\
30,97 \\
7,794 \\
0,621 \\
4,87 \\
5,393 \\
1,089 \\
2,994 \\
2,80 \\
0.353 \\
\end{array}$ & & $\begin{array}{l}16,44 \\
35.56 \\
12,72 \\
2,285 \\
0,396 \\
1,527 \\
1,412 \\
0,299 \\
0.892 \\
0,860 \\
0,132 \\
\end{array}$ \\
\hline $\begin{array}{c}\mathrm{L} a_{n} / L_{n} \\
L a_{n} / S m_{n} \\
E u_{n} / E u^{*} \\
E u_{n} / S m_{n} \\
G d_{n} / L u_{n} \\
E T R L / E T R P \\
\end{array}$ & $\begin{array}{c}23.845 \\
3,678 \\
0.358 \\
0.261 \\
2.968 \\
12.41 \\
\end{array}$ & $\begin{array}{c}30,493 \\
4,342 \\
0,407 \\
0.308 \\
3.617 \\
13.92 \\
\end{array}$ & $\begin{array}{c}4,813 \\
2,382 \\
0,335 \\
0,269 \\
1.220 \\
5.86 \\
\end{array}$ & $\begin{array}{l}8.907 \\
2.447 \\
0.288 \\
0.212 \\
1.715 \\
8.19 \\
\end{array}$ & & $\begin{array}{c}12.93 \\
4.53 \\
0.612 \\
0.46 \\
1.438 \\
13.18 \\
\end{array}$ \\
\hline
\end{tabular}


General Carneiro, são bem mais típicas de granitóides mais evoluidos, de derivação crustal. Os teores mais altos em ETR no Granito Santa Luzia poderiam ser explicados pela presença de allanita, mineral bastante rico nestes elementos.

Os granitos General Carneiro e Marzagão (Gair 1962) ocorrem lado a lado, porém sem relações de campo observáveis. O Granito Marzagão é bem mais pobre em minerais máficos e encontra-se fortemente cisalhado. Em termos de composição química exibe, em relação ao Granito General Carneiro, empobrecimento em $\mathrm{FeO}(t)$, secundariamente em $\mathrm{TiO}_{2}$, e aumento no teor de $\mathrm{Al}_{2} \mathrm{O}_{3}$ (Tabela 6). Isto poderia ser explicado pela sericitização da biotita durante o cisalhamento, implicando em que o Granito Marzagão possa constituir uma faixa milonitizada do Granito General Carneiro.

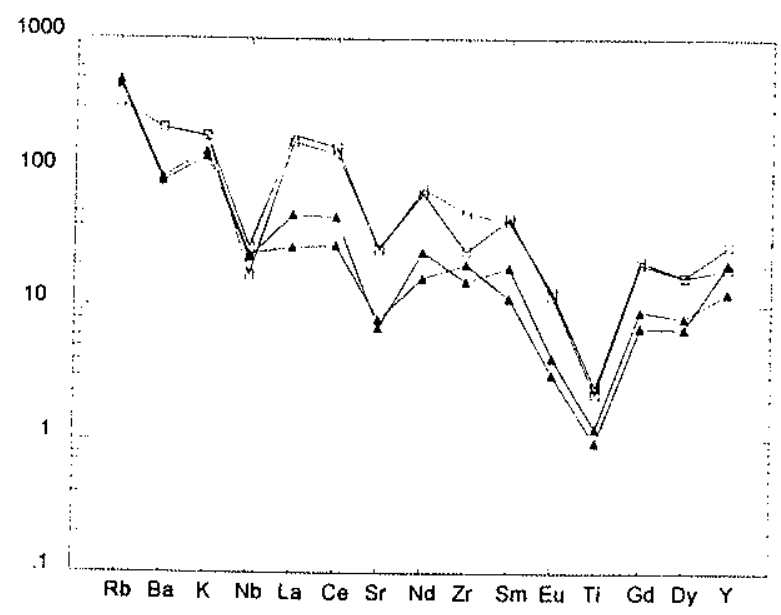

Figura 13: Diagrama de variação de elementos-traços, normalizados para o manto primitivo, para o Granito Santa Luzia (quadrados) e Granito General Carneiro (triângulos preenchidos).

O Granodiorito Ibirité possui apenas uma análise química disponível (Tabela 6). Sua curva de ETR encontra-se representada na figura 15. Em relação à suite TTG representada pelo Gnaisse Belo Horizonte, o Granodiorito Ibirité apresenta-se mais empobrecido em ETR e exibe fracionamento em ETRP bem menos acentuado. A média das razões $(\mathrm{Gd} / \mathrm{Lu})_{\mathrm{N}}$ para o Gnaisse Belo Horizonte é 3,43 contra uma razão de 1,44 para o Granodiorito Ibirité. 

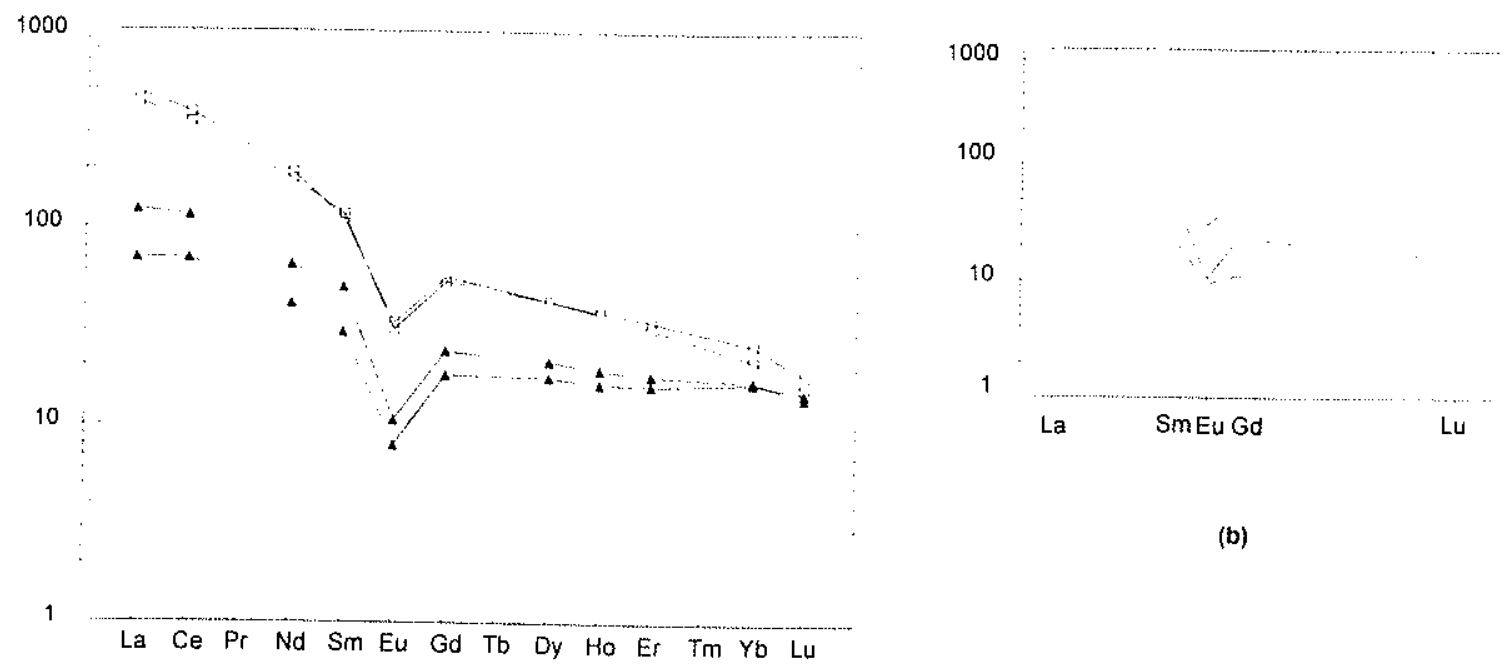

(a)

Figura 14: (a) Curvas de ETR, normalizadas para condritos (valores de normalização de Jensen et al. 1978), para o Granito Santa Luzia (quadrados) e Granito General Carneiro (triângulos preenchidos). (b) Diagrama comparativo entre as curvas de ETR para o Granito Santa Luzia (linha interrompida) e o Granito General Carneiro (linha cheia) e a curva média para o Gnaisse Belo Horizonte (linha tracejada).

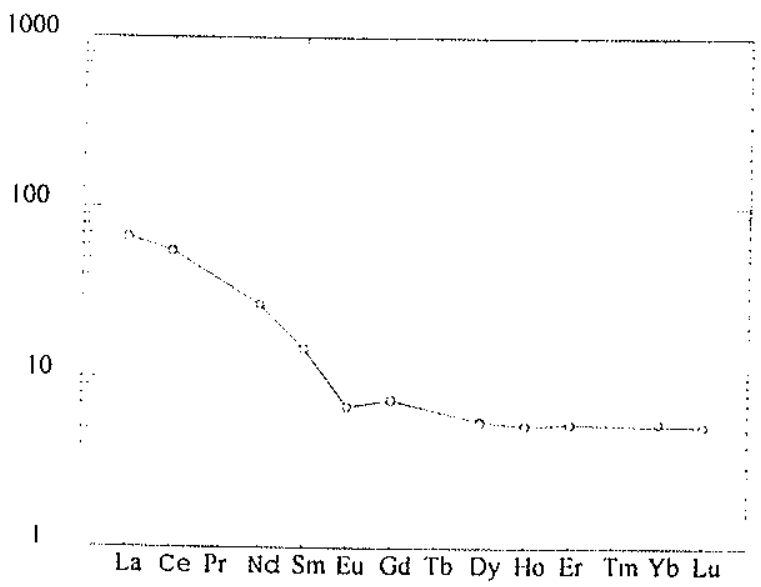

Figura 15: Curva de ETR, normalizada para condritos (valores de normalização de Jensen et al. 1978), para o Granodiorito Ibirité.

No Cráton Kaapval, África do Sul, os estágios finais da evolução da crosta continental arqueana são representados por granitos potássicos, pouco volumosos e de caráter isolado (e.g. 
Robb 1983). As características geoquímicas de duas suítes graníticas dessa natureza, designadas Mpageni e Sicunusa, são muito semelhantes às dos granitos Santa Luzia e General Carneiro (Figura 16). O modelo petrogenético apresentado por Robb (1983) relaciona os granitos Mpageni e Sicunusa a processos de cristalização fracionada diferenciados, mas partindo de um mesmo magma paterno. Este, por sua vez, seria derivado da fusão da crosta tonalítica primitiva.

Outro exemplo de granito arqueano tardio, muito similar ao Granito Santa Luzia em termos de composição química, é o Granito Little Elk, em Dakota do Sul (Estados Unidos). O modelo petrogenético para este granito também envolve a fusão parcial de crosta granodiorítica a tonalítica (Gosselin et al. 1990).

Os exemplos citados sugerem que os granitos Santa Luzia e General Carneiro poderiam ter-se originado da fusão do próprio Gnaisse Belo Horizonte. O padrão, relativamente semelhante, das curvas de ETR dos plutonitos e da curva média do Gnaisse Belo Horizonte (Figura 14b), é compatível com esta proposta de derivação. Entretanto, certas características, como as altas razões $\mathrm{Rb} / \mathrm{Sr}$ do Granito General Carneiro, indicam a contribuição de outras fontes para sua geração, possivelmente rochas supracrustais.

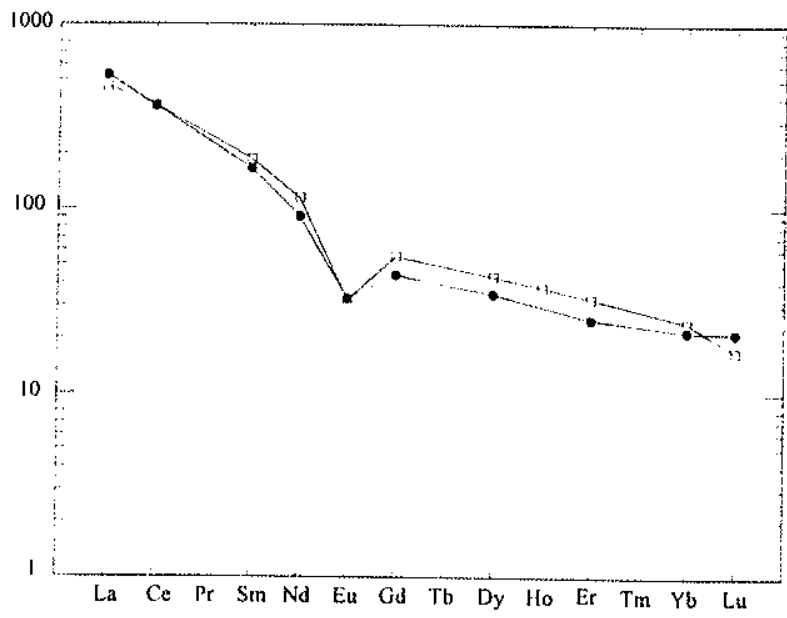

(a)

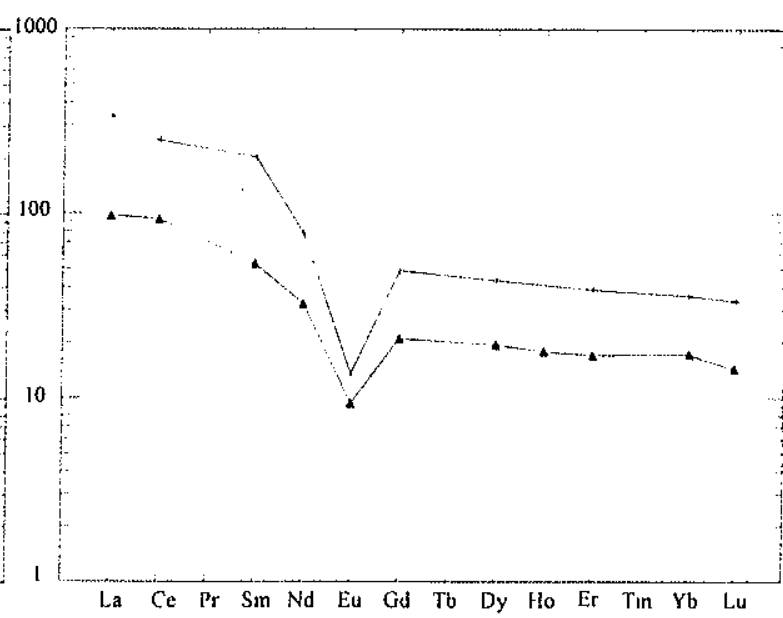

(b)

Figura 16: (a) Diagrama comparativo entre a curva média de ETR para o Granito Santa Luzia (quadrados) e o Granito Mpageni (círculos preenchidos). (b) Diagrama comparativo entre curva média de ETR para o Granito General Carneiro (triângulos preenchidos) e o Granito Sicunusa (cruzes). Curvas para os granitos Mpageni e Sicunusa segundo Condie (1981). Curvas normalizadas para condritos segundo os valores de normalização de Evensen et al. 1978. 


\subsection{GEOCRONOLOGIA}

As determinações geocronológicas para o Complexo Belo Horizonte incluiram os métodos $\mathrm{U}-\mathrm{Pb}, \mathrm{Rb}-\mathrm{Sr}$ e K-Ar. A localização das amostras analisadas encontra-se na figura 17.

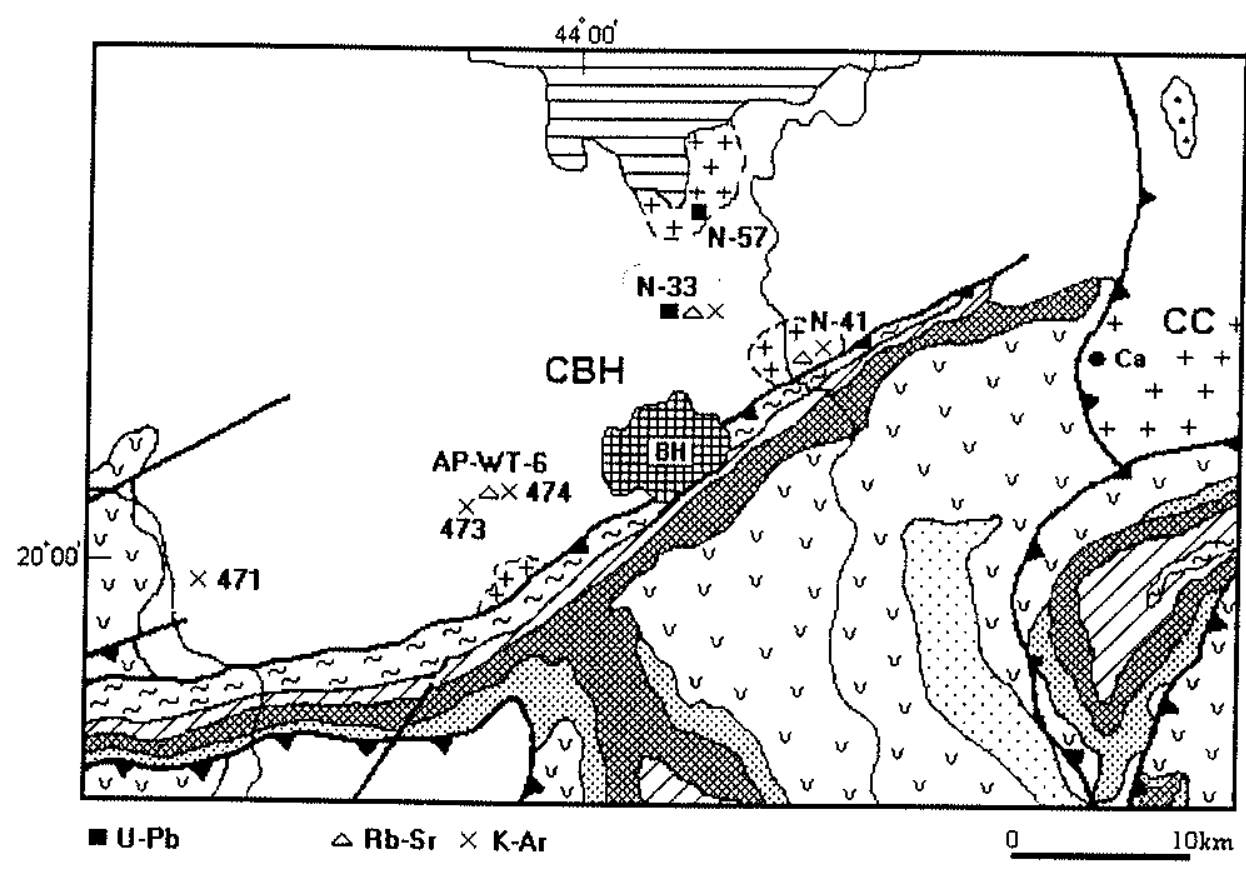

Figura 17: Localização das amostras com determinações geocronológicas no Complexo Belo Horizonte (Legenda: ver figura 3)

4.4.1. Gnaisse Belo Horizonte (amostra N-33A) e mobilizado migmatítico (amostra N-33B)

\subsubsection{Determinações $\mathrm{U}-\mathrm{Pb}$ :}

O Gnaisse Belo Horizonte, na exposição amostrada, apresentava-se muito migmatizado. com o desenvolvimento de mobilizados félsicos com espessura de até $1 \mathrm{~m}$. A amostra N-33A foi coletada em local onde a migmatização foi menos evidente macroscopicamente, manifestando-se pela blastese de feldspato e o aparecimento de finas bandas concordantes a algo discordantes de 
material félsico mais grosseiro. O material amostrado continha algumas destas bandas félsicas. devido à impossibilidade de separá-las. O zircões mostraram-se muito alterados, salvo por alguns fragmentos e prismas muito pequenos. A análise dos zircões desta rocha foi descartada por sua má qualidade. Por outro lado, as frações 1.0 e 1,7A do "Frantz Inicial" possuíam abundante titanita marrom escura, frequentemente com inclusões de biotita e bordos incolores.

Foram separadas duas frações de titanita, sendo selecionados os grãos mais escuros, portanto mais ricos em $U$, transparentes e livres de inclusões. A primeira fração (33A-1) sofreu abrasão a 2psi pelo tempo de $1 \mathrm{~h}$. A idade ${ }^{207} \mathrm{~Pb} / 206 \mathrm{~Pb}$ obtida foi de $2.312 \mathrm{Ma}, 5,68 \%$ discordante. A fração $33 \mathrm{~A}-2$ sofreu abrasão por tempo bem mais longo, $4 \mathrm{~h}$, fornecendo uma idade ${ }^{207} \mathrm{~Pb} / 206 \mathrm{~Pb}$ de $2.227 \mathrm{Ma}, 3,66 \%$ discordante. Uma terceira fração de titanita (33B-5) foi obtida da amostra $\mathrm{N}-33 \mathrm{~B}$, que corresponde a um mobilizado félsico da mesma pedreira. Obteve-se uma idade concordante $(0,83 \%$ discordante) de $2.041 \mathrm{Ma}$ (Tabela 7 e Figura 18).

As três frações alinham-se em uma discórdia onde o intercepto inferior, $2.041 \pm 5 \mathrm{Ma}$, é a idade da fração concordante 33B-5. Para o intercepto superior obteve-se $2.847+81 /-77 \mathrm{Ma}$ (Figura 18).

É curioso o fato de a fração de titanita $33 \mathrm{~A}-2$ ser mais discordante, em relação ao intercepto superior (86\%), que a fração 33A-1 (81\%), a qual sofreu abrasão por menos tempo. No caso do zircão, a abrasão em geral torna o grão mais concordante, mas o mesmo não é sempre válido para a titanita. Uma possível explicação para este fenômeno foi discutida por Parrish (1990). No zircão, após a cristalização, não parece ocorrer muita redistribuição de $\mathrm{Pb}$ radiogênico no interior do grão, mesmo quando submetido a eventos metamórficos de temperatura elevada. A perda de $\mathrm{Pb}$ concentra-se nas zonas externas do cristal, que são removidas pela abrasão. $\mathrm{Na}$ titanita o metamorfismo provocaria, além da perda de $\mathrm{Pb}$ radiogênico, a redistribuição interna deste. Logo, a abrasão poderia remover também partes externas do cristal que haviam ganho $\mathrm{Pb}$ radiogênico pela difusão intra-grão. No entanto, em alguns estudos a abrasão mostrou-se bastante efetiva na redução da discordância em análises de titanitas (e.g. Corfu 1988).

O mobilizado félsico (amostra N-33B) ocorre preenchendo charneira de dobra isoclinal deitada, exibindo espessura de cerca de $0,5 \mathrm{~m}$. A maior parte dos zircões da amostra apresentava alteração, sendo, em consequência, bastante magnéticos, ficando retidos na fração M5 do "Frantz Final" (fração magnética a $5^{\circ}$ de inclinação). A alteração dificultou uma análise tipológica mais criteriosa dos zircões. Foram, inicialmente, separados os prismas bem formados e morfologicamente semelhantes, onde a alteração era mais superficial. Ao serem partidos, exibiam interior rosa sem a presença evidente de núcleo. Os prismas foram divididos em três frações classificadas por tamanho. Cada fração sofreu rápido ataque por HF, que removeu parte da capa de alteração, e foi levada à abrasão. Após a abrasão foram selecionados, em cada fração, os fragmentos totalmente livres de alteração e de aspecto mais homogêneo, vindo a constituir as 
Tabela 7: Resultados analiticos U-Pb para o Gnaisse Belo Horizonte e Granito Santa Luzia (Complexo Belo Horizonte).

Amostra

Concentraçōes

Razōes Isotópicas

ldades (Ma)

Gnaisse Belo Horizonte (amostras $N-33 A$ e N-33B)

\begin{tabular}{|c|c|c|c|c|c|c|c|c|c|c|c|c|c|c|c|c|}
\hline $\begin{array}{c}N^{\circ} \mathrm{da} \\
\text { amostra }\end{array}$ & $\operatorname{Min}$ & $\begin{array}{c}\text { Prop. } \\
\text { mag.*2 }\end{array}$ & $\begin{array}{l}N^{\circ} \text { de } \\
\text { grăos }\end{array}$ & $\begin{array}{l}\text { Peso } \\
(\mathrm{mg})\end{array}$ & $\begin{array}{r}\text { Urânio } \\
\text { (ppm)*3 }\end{array}$ & $\begin{array}{c}\mathrm{Pb} \text { rad. } \\
(\mathrm{ppm})^{* 3}\end{array}$ & $\begin{array}{c}\mathrm{Pb} \text { com } \\
(\mathrm{pg})^{* 4}\end{array}$ & $\begin{array}{c}{ }^{206} \mathrm{~Pb} /{ }^{204} \mathrm{~Pb} \\
* 5\end{array}$ & $\underset{ }{{ }^{208} \mathrm{~Pb} /{ }^{206} \mathrm{~Pb}}$ & $\begin{array}{c}{ }^{206} \mathrm{~Pb} /{ }^{238} \mathrm{U} \\
* 6\end{array}$ & $\begin{array}{c}{ }^{207} \mathrm{~Pb} / \\
* 6\end{array}$ & $\begin{array}{c}{ }^{207} \mathrm{~Pb} /{ }^{206} \mathrm{~Pb} \\
* 6\end{array}$ & ${ }^{206} \mathrm{~Pb} /{ }^{235} \mathrm{U}$ & ${ }^{207} \mathrm{~Pb} /{ }^{235} \mathrm{U}$ & ${ }^{207} \mathrm{~Pb} /{ }^{200} \mathrm{~Pb}$ & \\
\hline $33 \mathrm{~B}-1$ & $\mathrm{Z}$ & M5 & 3 & 0,006 & 103 & 57 & 36 & 543 & 0,1251 & $0,4 \overline{8} 490$ & 13,346 & 0,19962 & 2549 & 2704 & 2823 & \\
\hline $33 \mathrm{~B}-2$ & Z & MS & 4 & 0,011 & 106 & 59 & 37 & 973 & 0,1435 & 0,48235 & 13,196 & 0,19842 & 2537 & 2694 & 2813 & \\
\hline $33 \mathrm{~B}-3$ & $z$ & M5 & 15 & 0,009 & 164 & 108 & 70 & 761 & 0,1668 & 0,55922 & 15,747 & 0,20423 & 2863 & 2861 & 2860 & $z$ \\
\hline $33 \mathrm{~B}-4$ & Z & NM11 & 1 & 0,005 & 75 & 47 & 41 & 331 & 0,0997 & 0.55713 & 16,303 & 0.21223 & 2855 & 2895 & 2923 & \\
\hline $33 \mathrm{~B}-5$ & T & IF & 40 & 0,155 & 185 & 81 & 592 & 1139 & 0,2476 & 0,36878 & 6,399 & 0,12585 & 2024 & 2032 & 2041 & \\
\hline $33 \mathrm{~A}-1$ & $\mathrm{~T}$ & IF & 42 & 0,184 & 181 & 109 & 518 & 1660 & 0,5708 & 0,40688 & 8,249 & 0,14705 & 2201 & 2259 & 2312 & \\
\hline $33 \mathrm{~A}-2$ & $\mathrm{~T}$ & IF & 30 & 0,196 & 187 & 106 & 751 & 1233 & 0,5125 & 0,39757 & 7,674 & 0,13999 & 2158 & 2194 & 2227 & \\
\hline
\end{tabular}

Granito Santa Luzia (amostra $N-57$ )

\begin{tabular}{|c|c|c|c|c|c|c|c|c|c|c|c|c|c|c|c|}
\hline$\frac{\begin{array}{c}\mathrm{N}^{\circ} \mathrm{da} \\
\text { amostra }\end{array}}{57-1}$ & $\begin{array}{l}\text { Min } \\
* 1 \\
Z\end{array}$ & $\begin{array}{l}\text { Prop. } \\
\text { mag }^{* 2}\end{array}$ & $\begin{array}{l}N^{\circ} \text { de } \\
\text { grăos }\end{array}$ & $\begin{array}{l}\text { Peso } \\
\text { (mg) }\end{array}$ & $\begin{array}{c}\text { Urânio } \\
(\mathrm{ppm})^{* 3}\end{array}$ & $\begin{array}{c}\text { Pb rad. } \\
(\mathrm{ppm})^{* 3}\end{array}$ & $\begin{array}{c}\mathrm{Pb} \text { com. } \\
(\mathrm{pg})^{* 4}\end{array}$ & $\begin{array}{c}{ }^{206} \mathrm{~Pb} /{ }^{204} \mathrm{~Pb} \\
\end{array}$ & $\begin{array}{c}{ }^{208} \mathrm{~Pb} /{ }^{206} \mathrm{~Pb} \\
* 6\end{array}$ & $\begin{array}{c}{ }^{206} \mathrm{~Pb} /{ }^{238} \mathrm{U} \\
* 6\end{array}$ & $\begin{array}{c}{ }^{207} \mathrm{~Pb} /{ }^{235} \mathrm{U} \\
\end{array}$ & $\begin{array}{c}{ }^{207} \mathrm{~Pb} /{ }^{200} \mathrm{~Pb} \\
* 6\end{array}$ & ${ }^{200} \mathrm{~Pb} / 238 \mathrm{U}$ & ${ }^{207} \mathrm{~Pb} /{ }^{235} \mathrm{U}$ & ${ }^{207} \mathrm{~Pb} /{ }^{200} \mathrm{~Pb}$ \\
\hline $57-1$ & Z & NMI & 8 & 0,010 & 167 & 94 & 61 & 785 & 0,2630 & 0,45131 & 11,325 & 0,18199 & 2401 & 2550 & 2671 \\
\hline $57-2$ & $Z$ & M1 & 16 & 0,019 & 84 & 49 & 5,7 & 8576 & 0,2322 & 0,48288 & 12,264 & 0,18420 & 2540 & 2625 & 2691 \\
\hline $57-3$ & Z & M3 & 13 & 0,015 & 85 & 49 & 9,9 & 3831 & 0,2210 & 0,47578 & 12,046 & 0,18363 & 2509 & 2608 & 2686 \\
\hline $57-4$ & $T$ & IF & 50 & 0,536 & 103 & 67 & 2193 & 631 & 0,8079 & 0,38932 & 7,449 & 0,13878 & 2120 & 2167 & 2212 \\
\hline $57-5$ & $\mathrm{r}$ & $\mathrm{IF}$ & 30 & 0,346 & 141 & 97 & 1824 & 671 & 0,8369 & 0,40099 & 7,985 & 0,14443 & 2174 & 2229 & 2281 \\
\hline $57-6$ & $\mathrm{~T}$ & $\mathrm{AF}$ & 15 & 0,204 & 151 & 108 & 1351 & 600 & 0,8683 & 0,40903 & 8,373 & 0,14847 & 2210 & 2272 & 2328 \\
\hline $57-7$ & $r$ & IF & 20 & 0,254 & 162 & 111 & 1939 & 558 & 0,7945 & 0.40744 & 8,158 & 0,14522 & 2203 & 2249 & 2290 \\
\hline
\end{tabular}

*1-Z=zircão, T=titanita.

*2- Propriedades magnéticas: NM/M, não magnético/magnético no ângulo indicado de inclinação do separador magnético FRANTZ, a 1,8A e $0^{\circ}$ de inclinação lateral; IF, não magnético entre 1.0 .4 e $1,8 \mathrm{~A}$ com $10^{\circ}$ de inclinação lateral.

*3- Concentraçðes såo conhecidas com precisåo de $2 \%$ para amostras pesando $0,4 \mathrm{mg}, 10-20 \%$ para amostras abaixo de 0,020mg. Para amostras cujo peso está abaixo da sensibilidade da balança,

$0,001 \mathrm{mg}$, as concentraçðes listados sà

*4- $\mathrm{Pb}$ comum total corrigido para o $\mathrm{Pb}$ comum do spike.

*5- Razão medida corrigida apenas para o fracionamento.

*6- Razðes corrigidas para o spike, fracionamento, branco e Pb comum inicial. 
frações analisadas 33B-1, 33B-2 e 33B-3. A fração 33B-4 era composta por um único prisma. menos magnético que os anteriores e de cor vermelha. apenas levemente alterado.

A fração 33B-3 é concordante a $2.860 \mathrm{Ma}$, enquanto as frações 33B-1 e 33B-2 apresentam idades ${ }^{207} \mathrm{~Pb} / 206 \mathrm{~Pb}$ semelhantes e são em torno de $11 \%$ discordantes (Tabela 7 e Figura 18). Uma discórdia passando por estes três pontos forneceu um intercepto superior de $2.860+14 /-10 \mathrm{Ma}$. com probabilidade de ajuste de $23 \%$. Esta idade do intercepto superior é controlada por uma análise concordante, o que faz com que seja bastante confiável. A fração 33B-4, mais pobre em $\mathrm{U}$ que as demais, apresentou idade ${ }^{207} \mathrm{~Pb} / 206 \mathrm{~Pb}$ de $2.922 \mathrm{Ma}, 2,3 \%$ discordante.

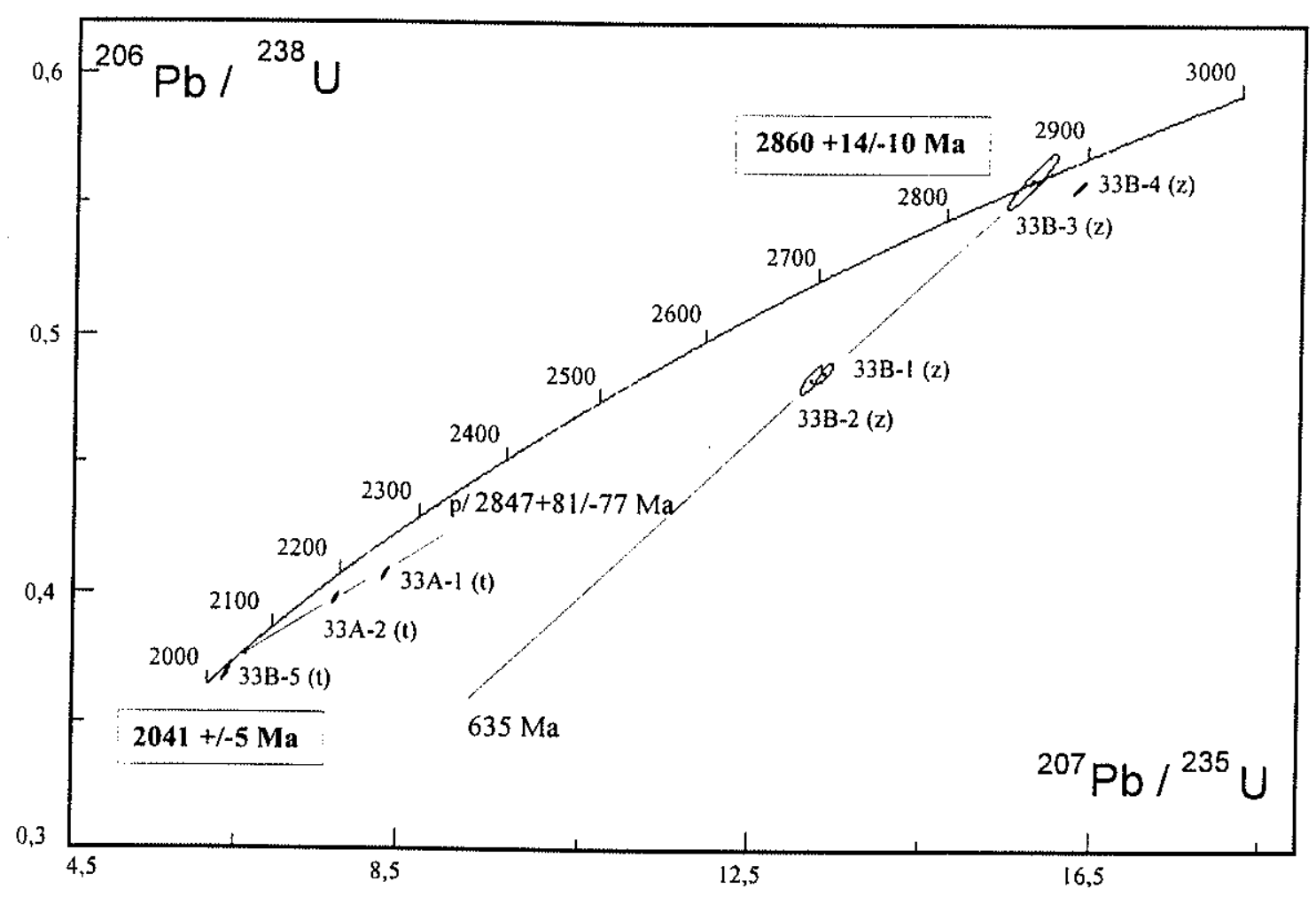

Figura 18: Diagrama concórdia para o gnaisse migmatítico do Complexo Belo Horizonte (amostra N-33A) e mobilizado félsico (amostra N-33B). Legenda: $z=$ zircão; $t=$ titanita.

Os zircões das frações 33B-1, 33B-2 e 33B-3 eram euédricos, sem evidências claras de arredondamento causado por reabsorção metamórfica. Adicionalmente, o caráter colinear das análises sugere que as frações incluíam apenas zircões gerados em um único evento. Portanto, a interpretação mais confiável é que os zircões se cristalizaram durante o evento gerador do 
mobilizado félsico, datando a migmatização em 2.860+14/-10 Ma. Nota-se, também. que esta idade está na mesma faixa do intercepto superior da discórdia de titanitas. O zircão da fração 33B-4, com idade mínima de $2.922 \mathrm{Ma}$, deve ser um cristal herdado da rocha-fonte, no caso o Gnaisse Belo Horizonte.

Outra hipótese é que a idade de geração do mobilizado félsico seja dada pela análise de sua fração de titanita, concordante a $2.041 \mathrm{Ma}$ (fração 33B-5). Neste caso, todos os zircões analisados seriam xenocristais. Esta alternativa é improvável, considerando que as titanitas do gnaisse, do mesmo afloramento, preservam $\mathrm{Pb}$ radiogênico mais antigo, enquanto a discórdia de zircão não registra o evento de $2.041 \mathrm{Ma}$. Esse comportamento do sistema isotópico U-Pb, nos dois minerais, é mais condizente com um retrabalhamento metamórfico, por volta de $2.041 \mathrm{Ma}$. em temperaturas não muito elevadas, insuficientes para promover a migmatização do gnaisse. Nos casos em que o metamorfismo é de mais alto grau, zircão e titanita tenderiam a se alinhar em uma discórdia única, entre a idade de cristalização e a do evento metamórfico (e.g Tucker et al. 1987, Tucker \& Krogh 1988). Entretanto, os processos de difusão do $\mathrm{Pb}$ em eventos metamórficos não são bem conhecidos (e.g. Heaman \& Parrish 1991). O melhor argumento contrário à hipótese em discussão é geológico, ou seja, a migmatização do Gnaisse Belo Horizonte é, com grande probabilidade, anterior à intrusão dos granitos neoarqueanos da área estudada (seção 4.4.2.).

O padrão apresentado pelas análises de titanitas encontra paralelo em situações descritas na literatura, com destaque para o trabalho de Tucker et al. (1987). Neste, análises de titanitas de um terreno gnáissico na Noruega distribuem-se ao longo de uma discórdia definida por dois eventos geológicos maiores; um evento magmático e metamórfico ca. $1.652 \mathrm{Ma}$ e um evento metamórfico, de grau médio a alto, ca. $396 \mathrm{Ma}$. Os autores observaram que, quanto maior o grau metamórfico do segundo evento, maior era a discordância em relação ao intercepto superior. Esta situação definiria um comportamento "ideal" para o sistema isotópico da titanita, quando submetida a um evento metamórfico. Entretanto, o resetting durante o metamorfismo pode ser infuenciado por condições muito localizadas, como conteúdo em U, presença de fluidos e reações de recristalização (Nunn et al. 1990).

Em conclusão, a melhor interpretação é que as titanitas foram geradas, ou sofreram resetting, durante o evento metamórfico principal do Arqueano, ca. 2.860+14/-10 Ma. Este fato é corroborado pela discórdia obtida para as titanitas (Figura 18), apontando para um intercepto superior de 2.874+81/-77 Ma. Por volta de 2.041 $\pm 5 \mathrm{Ma}$, um novo evento metamórfico causou severa perda de $\mathrm{Pb}$ radiogênico, podendo inclusive ter provocado a cristalização de novas titanitas (no caso a fração $33 \mathrm{~B}-5$, que é concordante). Considerando que a temperatura de bloqueio para a titanita é estimada em torno de $500^{\circ} \mathrm{C}$ (Mattinson 1978), e como as titanitas são 
mais de $80 \%$ discordantes em relação ao intercepto superior. a temperatura atingida por esse evento deve ter sido dessa ordem, condizente com a fácies anfibolito.

Conforme referido anteriormente, a discórdia de zircão não mostra o efeito do evento de $2.041 \pm 5 \mathrm{Ma}$. O intercepto inferior aponta para $635 \mathrm{Ma}$, com erros muito grandes, visto os pontos situarem-se próximos do intercepto superior. A idade de $635 \mathrm{Ma}$ coloca-se na faixa de idades atribuídas ao Evento Brasiliano, cuja ação termal teve baixa magnitude na área do Complexo Belo Horizonte, não chegando a ser registrada pelo sistema isotópico K-Ar de biotitas (seção 4.4.4.). É possível que, ao contrário de registrar um evento singular de perturbação do sistema isotópico ca. $635 \mathrm{Ma}$, o intercepto inferior resulte do efeito integrado de múltiplos eventos de perda de $\mathrm{Pb}$. Esta interpretação baseia-se em discussão sobre o significado dos interceptos inferiores para discórdias do Cinturão Abitibi, por Corfu (1993).

O trabalho de Davis et al. (1989) constitui uma boa ilustração desta problemática acerca do valor geológico do intercepto inferior em discórdias de zircão. As análises de zircões de uma rocha vulcânica e outra subvulcânica, oriundas de uma sequência greenstone belt da Província Superior (Canadá), definiram duas discórdias com intercepto superior igual em $2.728 \mathrm{Ma}$, interpretado como idade de cristalização. Entretanto, apesar de os dois corpos rochosos estarem em contato, o intercepto inferior de cada uma das discórdias era muito diferente. As idades dos interceptos inferiores, 794 e $293 \mathrm{Ma}$, não eram correlacionáveis a evento geológico conhecido para a região. Davis et al. (1989) concluíram que os processos de perda de $\mathrm{Pb}$ no zircão podem, em certos casos, depender muito mais das propriedades locais da rocha que da história geológica regional.

\subsubsection{Determinacões Rb-Sr:}

Procedeu-se a uma análise $\mathrm{Rb}$-Sr do mesmo gnaisse migmatítico estudado pelo método U$\mathrm{Pb}$ (amostra $\mathrm{N}-33$ ). As amostras coletadas incluíram porções de paleossoma, mesossoma e neossoma. Obteve-se uma isócrona $\mathrm{Rb}-\mathrm{Sr}$ de cinco pontos, com idade de $2.619 \pm 65 \mathrm{Ma}$. A razão inicial é de 0,70265 $\pm 0,00088$ e o MSWD igual a 1,58 (Tabela 8 e Figura 19). No diagrama isocrônico (Figura 19), as amostras 33-1 e 33-4 são de porções mais máficas e as amostras 33-5, 33-6 e 33-9 são de porções bandadas ou mais homogêneas do gnaisse. $O$ bom alinhamento indica uma re-homogeneização completa do sistema isotópico $\mathrm{Rb}$-Sr em evento posterior ao episódio de migmatização (datado em $2.860+14 /-10 \mathrm{Ma}$ ).

Existe outra isócrona para gnaisses do Complexo Belo Horizonte, região de ContagemBetim, com idade de $2.630 \pm 166 \mathrm{Ma}, \mathrm{Ri}=0,7014 \pm 0,0014$ e $\mathrm{MSWD}=3,53$ (Teixeira et al. 1994). 
As idades isocrônicas, por volta de 2.700-2.600 Ma, marcam a re-homogeneização isotópica principal do Gnaisse Belo Horizonte em termos do sistema Rb-Sr. Duas hipóteses podem ser levantadas para explicar este processo. $\mathrm{Na}$ primeira, os gnaisses migmatizados ca. $2.860 \mathrm{Ma}$ permaneceram em níveis crustais profundos por mais 100-200 $\mathrm{Ma}$ até que as temperaturas diminuíssem a ponto de cessar a difusão isotópica do $\mathrm{Sr}$. A outra alternativa é que a intrusão de granitóides do Neoarqueano, com idades igualmente no período $2.700-2.600 \mathrm{Ma}$ (Machado et al. 1992, Machado \& Carneiro 1992 e seção 4.4.2. deste trabalho), tenha sido responsável pelo re-equilibrio do sistema $\mathrm{Rb}-\mathrm{Sr}$ do Gnaisse Belo Horizonte.

As baixas razões iniciais para o Gnaisse Belo Horizonte, entre 0,701 e 0,703 , são indicativas de um protólito com baixas razões $\mathrm{Rb} / \mathrm{Sr}$. Desta forma, a migmatização do gnaisse (ca. $2860 \mathrm{Ma}$ ) não implicou em enriquecimento substancial da assinatura de Sr radiogênico.

Tabela 8: Dados isotópicos $R b$-Sr em rocha total para o Gnaisse Belo Horizonte, amostra N-33.

\begin{tabular}{|c|c|c|c|c|c|}
\hline $\begin{array}{c}N^{\circ} \\
\text { Amostra }\end{array}$ & $\begin{array}{l}N^{\circ} \text { Lab. } \\
\text { CPGeo }\end{array}$ & $\begin{array}{c}\mathrm{Rb} \\
(\mathrm{ppm})\end{array}$ & $\begin{array}{c}\mathrm{Sr} \\
(\mathrm{ppm})\end{array}$ & ${ }^{87} \mathrm{Rb} /{ }^{86} \mathrm{Sr}$ & ${ }^{87} \mathrm{Sr} / 86 \mathrm{Sr}$ \\
\hline $33-1$ & 11877 & 148,0 & 662,0 & $0,6480 \pm 0,0180$ & $0,727270 \pm 0,000070$ \\
\hline 33.4 & 11878 & 134,0 & 631,7 & $0,6150 \pm 0,0170$ & $0,725870 \pm 0,000080$ \\
\hline $33-5$ & 11879 & 168,6 & 219,5 & $2,2400 \pm 0,0630$ & $0,785860 \pm 0,000110$ \\
\hline $33-6$ & 11880 & 156,4 & 241,3 & $1,8890 \pm 0,0530$ & $0,777710 \pm 0,000160$ \\
\hline $33-9$ & 11882 & 170,3 & 232,6 & $2,1320 \pm 0,0600$ & $0,780890 \pm 0,000090$ \\
\hline
\end{tabular}

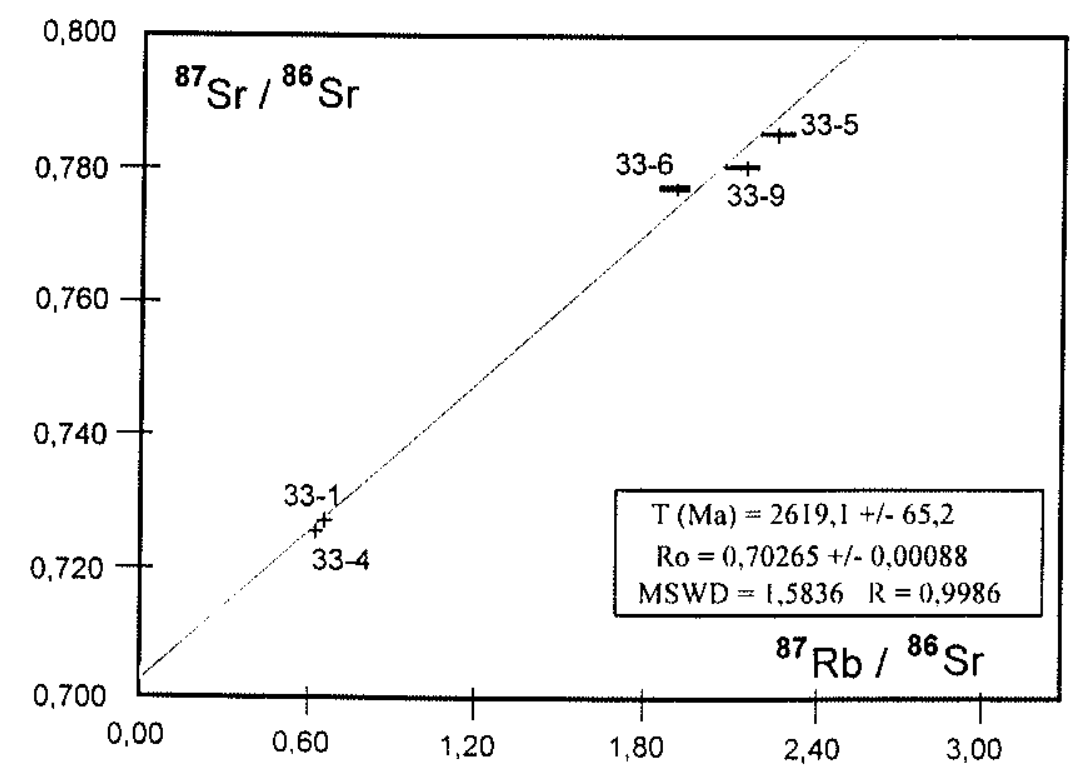

Figura 19: Diagrama isocrônico Rb-Sr em rocha total para o Gnaisse Belo Horizonte, Pedreira do Bairro Tupi (amostra N-33). 


\subsubsection{Granito Santa Luzia (amostra N-57)}

Para este corpo foi realizada apenas datação pelo método U-Pb. A rocha apresentava prismas grandes de zircão, sem núcleo visivel e sempre com alguma alteração esbranquiçada. Possuia também fragmentos límpidos, cor rosa homogênea, nos quais podiam-se observar restos de arestas bem definidas. Optou-se pela seleção desses fragmentos. A amostra 57-1 provinha da fração NM1 do "Frantz Final" e continha 9 fragmentos. A amostra 57-2, da fração M1, continha 16 fragmentos e a amostra 57-3, da fração M3, 15 fragmentos. Os três pontos definem uma discórdia com intercepto superior a 2.712+5/-4 Ma e probabilidade de ajuste de $56 \%$ (Tabela 7 , Figura 20). As frações 57-1, 57-2 e 57-3 apresentam uma discordância de, respectivamente, 17\%, $9 \%$ e $11 \%$. O pequeno tamanho dos fragmentos individuais permitiu apenas uma abrasão rápida (4h), o que explica a discordância elevada das análises. Como se pode observar, a amostra proveniente da fração menos magnética (57-1) é a mais discordante, ao contrário do esperado.

A similaridade entre as idades ${ }^{207} \mathrm{~Pb} / 206 \mathrm{~Pb}$ das frações analisadas sugere a cogeneticidade dos grãos. Desta forma, a idade 2.712+5/-4 Ma é interpretada como a de cristalização do granito. O intercepto inferior da discórdia, com $596 \mathrm{Ma}$, reproduz a mesma situação observada para o Gnaisse Belo Horizonte, sendo válidas as considerações feitas naquele caso (seção 4.4.1.1.).

A fração 1,0A do "Frantz Inicial" continha titanita marrom, sendo separadas quatro amostras, que sofreram abrasão por períodos diferentes de tempo a pressão de 2psi: 57.4 (1h),

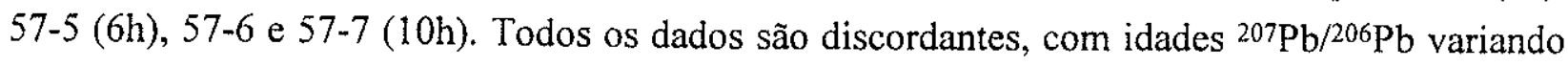
entre $2.212 \mathrm{Ma}$ e $2.328 \mathrm{Ma}$ (Tabela 7, Figura 20). As idades mínimas posicionam-se entre o evento arqueano de cristalização do corpo $(2.712+5 /-4 \mathrm{Ma})$ e o evento metamórfico transamazônico $(2.041 \pm 5 \mathrm{Ma})$.

A situação das análises de titanita do Granito Santa Luzia possui semelhança com o encontrado para as titanitas do Gnaisse Belo Horizonte (Figura 18). Entretanto, as frações não se alinham em uma discórdia. Ao se traçar uma discórdia entre 2.712 e $2.041 \mathrm{Ma}$, constata-se que as titanitas posicionam-se abaixo desta (Figura 20). Isto poderia ser explicado por algum processo de perda de $\mathrm{Pb}$ por difusão a baixa temperatura, ocorrendo após o último evento metamórfico importante ( $c$. $2.041 \mathrm{Ma}$ ). Corfu (1988) descreve situações onde titanitas tiveram seu sistema isotópico afetado por processos hidrotermais, cuja atuação estendeu-se por longos períodos após o pico metamórfico.

Os dados sugerem que as titanitas foram geradas durante a cristalização do corpo granítico, no Neoarqueano. Uma evidência indireta a favor desta hipótese é dada pelas razões Th/U

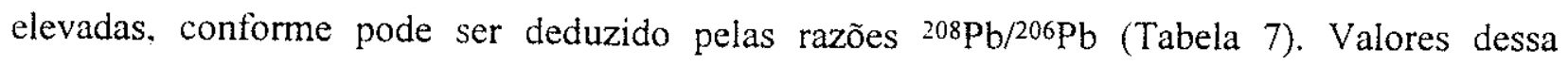
magnitude são mais típicos das titanitas magmáticas (e.g. Davis \& Jackson 1988). O metamorfismo transamazônico ocasionou severa perda de $\mathrm{Pb}$ nas titanitas, enquanto pertubações 
posteriores do sistema isotópico provocaram perdas secundárias, responsáveis pelo não alinhamento das frações analisadas. Evidências da atuação de processos pós-transamazônicos são também fornecidas por determinações Rb-Sr e K-Ar, no âmbito do Complexo Belo Horizonte, como se verá nas seções seguintes.

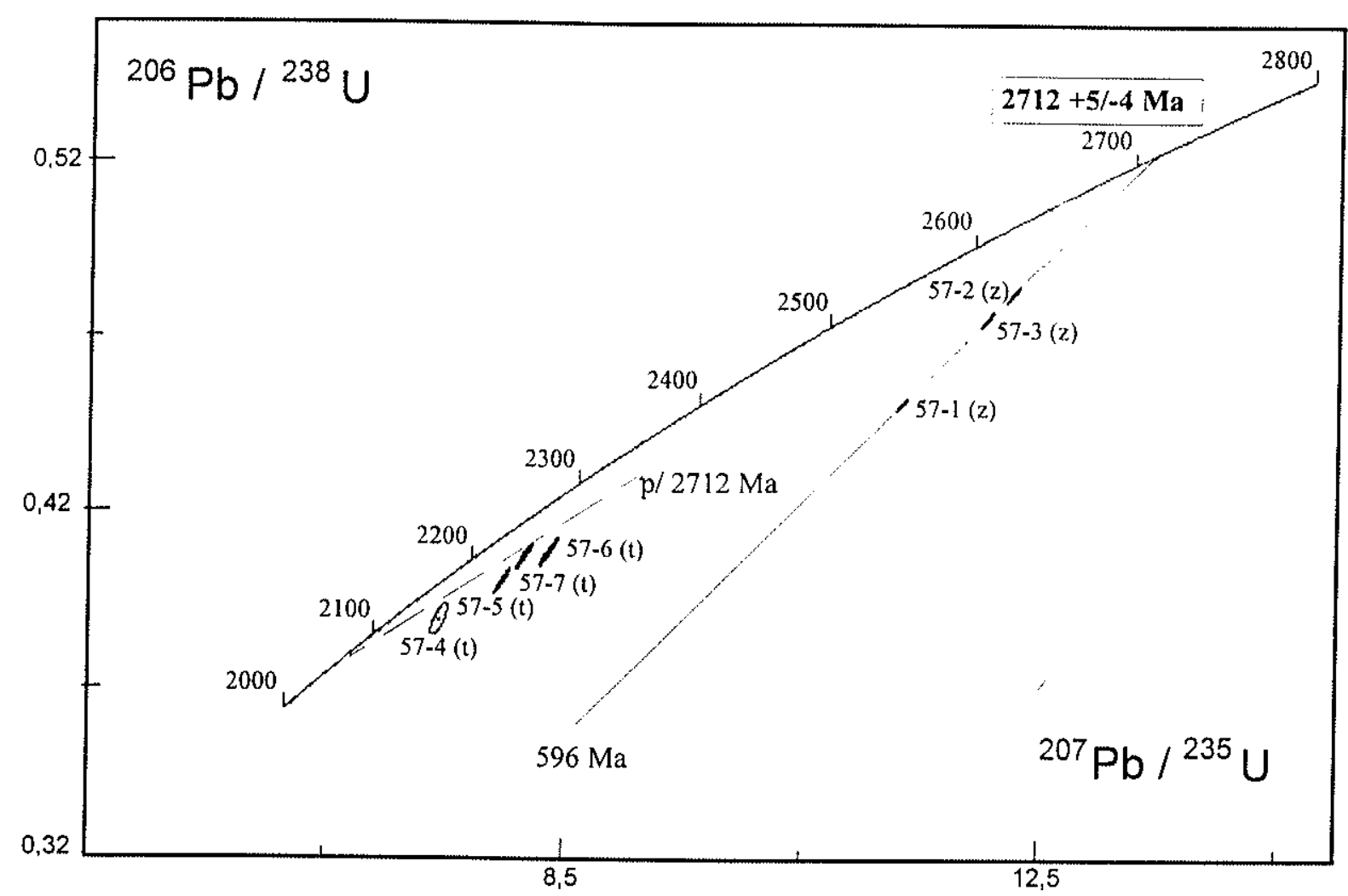

Figura 20: Diagrama concórdia para o Granito Santa Luzia (amostra N-57). Legenda: $z=$ zircão; $t=$ titanita.

\subsubsection{Granito General Carneiro (amostra N-41)}

Os zircões desta rocha eram muito pequenos e apresentavam-se fortemente alterados, impossibilitando a realização de análise U-Pb. Optou-se por efetuar uma datação $\mathrm{Rb}$-Sr em afloramento. Foi obtida uma errócrona com nove pontos e idade de $1.740 \pm 53 \mathrm{Ma}$ (MSWD=13,4). A razão inicial é muito elevada, igual a 0,78493 $\pm 0,00410$ (Tabela 9, Figura 21), indicando tratar-se de re-homogeneização de material crustal. 
Existem evidências geológicas de que o Granito General Carneiro seja, aproximadamente. contemporâneo ao Granito Santa Luzia, posicionando-o no Neoarqueano. Desta forma. espera-se que tenha sido afetado pelo Evento Transamazônico (ca. 2.041 Ma). A idade Rb-Sr de $1.740 \pm 53$ Ma deve refletir um reequilíbrio isotópico, incompleto e tardio, do sistema $\mathrm{Rb}$-Sr, em época póstransamazônica. Carneiro \& Teixeira (1992) constataram fato semelhante no Complexo Bonfim, que atribuíram a processos de circulação de fluidos propiciado pela retomada tectônica de zonas de cisalhamento pretéritas. O sistema isotópico $\mathrm{U}-\mathrm{Pb}$, nas titanitas do Granito Santa Luzia, mostra igualmente evidências de pertubações em época pós-transamazônica.

Tabela 9: Dados isotópicos Rb/Sr em rocha total para o Granito General Carneiro, amostra $N-4 l$.

\begin{tabular}{|cccccc|}
\hline $\begin{array}{c}\mathrm{N}^{\mathrm{o}} \\
\text { Amostra }\end{array}$ & $\begin{array}{c}\mathrm{N}^{\circ} \text { Lab. } \\
\text { CPGeo }\end{array}$ & $\begin{array}{c}\mathrm{Rb} \\
(\mathrm{ppm})\end{array}$ & $\begin{array}{c}\mathrm{Sr} \\
(\mathrm{ppm})\end{array}$ & ${ }^{87 \mathrm{Rb} / 86 \mathrm{Sr}}$ & $87 \mathrm{Sr} / 86 \mathrm{Sr}$ \\
\hline $41 \mathrm{~B}$ & 11909 & 242,3 & 103,8 & $6.9130 \pm 0,1910$ & $0.944320 \pm 0,000130$ \\
$41 \mathrm{C}$ & 11910 & 249,1 & 116,7 & $6,3350 \pm 0,1750$ & $0,965460 \pm 0,000160$ \\
$41 \mathrm{E}$ & 11911 & 264,6 & 109,0 & $7,2050 \pm 0,1990$ & $0,966820 \pm 0,000150$ \\
$41 \mathrm{~F}$ & 11912 & 299,0 & 105,0 & $8,4630 \pm 0,2330$ & $0,980780 \pm 0,000110$ \\
$41 \mathrm{I}$ & 11913 & 226,8 & 83,0 & $8,1150 \pm 0,2240$ & $0,973260 \pm 0,000070$ \\
$41 \mathrm{~N}$ & 11914 & 266,9 & 135,1 & $5,8500 \pm 0,1620$ & $0,942530 \pm 0,000060$ \\
$41 \mathrm{O}$ & 11915 & 189,6 & 110,4 & $5,0600 \pm 0,1410$ & $0,891140 \pm 0,000060$ \\
$41 \mathrm{~L}$ & 11916 & 178,5 & 165,0 & $3,1810 \pm 0,0890$ & $0,868390 \pm 0,000060$ \\
$41 \mathrm{~K}$ & 11917 & 202,5 & 136,4 & $4,3780 \pm 0,1210$ & $0,898730 \pm 0,000100$ \\
\hline
\end{tabular}

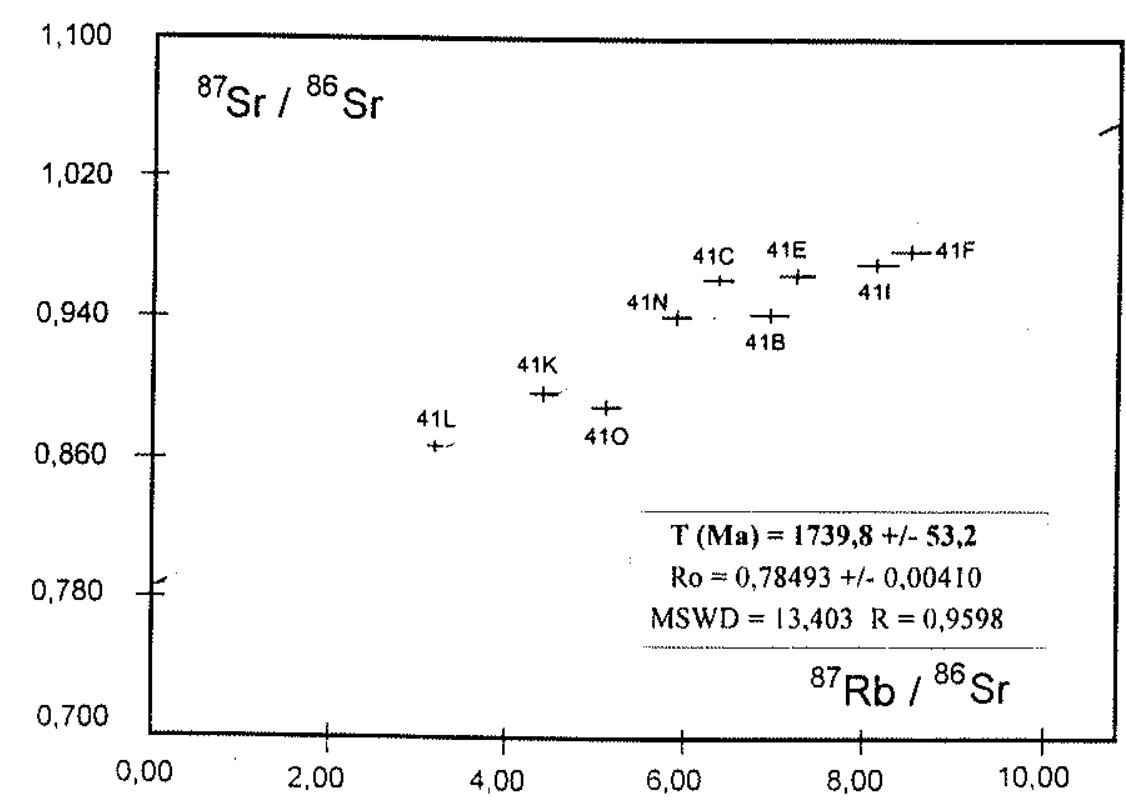

Figura 21: Diagrama isocrônico Rb-Sr em rocha total para o Granito General Carneiro (amostra $N-41$ ). 


\subsubsection{Determinações K-Ar para o Complexo Belo Horizonte}

As primeiras determinações geocronológicas em rochas do Complexo Belo Horizonte, pelo método K-Ar, são devidas a Herz et al. (1961). Foram analisadas duas amostras dos gnaisses, uma da Pedreira Prado Lopes e outra de uma pedreira da zona oeste de Belo Horizonte. Para a primeira obteve-se a idade K-Ar em biotita de $1.360 \mathrm{Ma}$, enquanto a segunda forneceu idade KAr em moscovita de $595 \mathrm{Ma}$.

Um conjunto de análises K-Ar, para o Complexo Belo Horizonte e regiões a leste deste, foram realizadas por $\mathrm{W}$. Teixeira (com. escrita) e encontram-se apresentadas na tabela 10 . As amostras $1119 / 471,1119 / 473$ e 1119/474 provêm de gnaisses da região de Betim-Contagem, as amostras CAE/RG-2E/D e CAE/RG-05 de gnaisse milonitizado do Complexo Caeté e a amostra W-MP de um anfibolito, coletado na Mina do Pari (a leste do Quadrilátero Ferrifero). No presente estudo foram feitas determinações em biotitas de um pegmatito cortando o Gnaisse Belo Horizonte (amostra N-33G) e do Granito General Carneiro (amostra N-41L). A localização destas amostras encontra-se na figura 17.

Tabela 10: Dados isotópicos $K$-Ar para o Complexo Belo Horizonte, Complexo Caeté e região leste do Quadrilátero Ferrifero.

\begin{tabular}{|ccccccc|}
\hline $\mathrm{N}^{\circ}$ Amostra & $\begin{array}{c}\mathrm{N}^{\circ} \text { Lab. } \\
\text { CPGeo }\end{array}$ & $\begin{array}{c}\text { Rocha/ } \\
\text { Mineral } \\
\text { b=bio,m=mosc }\end{array}$ & K (\%) & $\begin{array}{c}40 \mathrm{Ar} \text { atm } \\
(\%)\end{array}$ & $\begin{array}{c}40 \mathrm{Ar} \text { rad. } \\
\left(10^{-6}\right. \\
\text { ccSTP/g) }\end{array}$ & Idade (Ma) \\
\hline $1119 / 471^{*}$ & 5816 & gnaisse(b) & 6,11 & 6,97 & 609,71 & $1.597 \pm 38$ \\
$1119 / 473^{*}$ & 5819 & gnaisse(b) & 6,37 & 1,47 & 618,32 & $1.568 \pm 32$ \\
$1119 / 474^{*}$ & 5824 & gnaisse(b) & 5,38 & 3,98 & 340,88 & $1.161 \pm 27$ \\
N-33G & 7280 & pegmatito(b) & 1,70 & 2,11 & 202,78 & $1.798 \pm 96$ \\
N-41L & 7279 & granito(b) & 3,63 & 5,11 & 189,77 & $1.007 \pm 35$ \\
CAE/RG-2E/D* & 6596 & gnaisse(m) & 6,88 & 4,06 & 273,63 & $812 \pm 22$ \\
CAE/RG-D5* & 6599 & gnaisse(b) & 7,37 & 10,13 & 170,00 & $514 \pm 7$ \\
W-MP* & 5826 & anfibolito(b) & 6,85 & 2,22 & 151,24 & $494 \pm 12$ \\
\hline
\end{tabular}

Considerando que o pico termal do Evento Transamazônico, na área do Complexo Belo Horizonte, ocorreu por volta de $2.041 \pm 5 \mathrm{Ma}$, idades $\mathrm{K}$-Ar em biotita da ordem de $1.800 \mathrm{Ma}$ poderiam marcar o resfriamento final deste evento. Entretanto. com excessão de uma das 
determinações, todas as demais registram rejuvenescimentos posteriores do sistema isotópico KAr. A ampla distribuição dessas idades de biotita (1.600-1.100 Ma) poderia caracteriza-las como idades mistas, resultantes de processos de abertura parcial do sistema isotópico K-Ar, em eventos do Ciclo Espinhaço e/ou Brasiliano. A leste do Complexo Belo Horizonte, verifica-se a tendência de rejuvenescimento total durante o Evento Brasiliano.

\subsection{DISCUSSÃO DOS RESULTADOS}

O arcabouço geológico do Complexo Belo Horizonte é constituído por rochas gnáissicas do tipo TTG (Gnaisse Belo Horizonte), que sofreram importante evento de migmatização em 2.860+14/-10 Ma. A assinatura geoquímica do Gnaisse Belo Horizonte sugere que estas rochas representem a crosta arqueana juvenil. A idade do evento magmático que gerou o Gnaisse Belo Horizonte é desconhecida, mas um zircão herdado de um mobilizado migmatítico possuía idade mínima de $2.922 \mathrm{Ma}$.

A migmatização a $2.860+14 /-10 \mathrm{Ma}$ associa-se a um evento de deformação intensa do Gnaisse Belo Horizonte, com desenvolvimento da foliação principal, orientada preferencialmente segundo N-S, e dobramento apertado de baixo ângulo.

O Complexo Belo Horizonte foi afetado por um evento de granitogênese no Neoarqueano, representado pela intrusão do Granito Santa Luzia, em 2.712+5/-4 Ma. Evidências indiretas indicam que o Granito General Carneiro posicionou-se nessa mesma época. Igualmente contemporânea foi a intrusão do Granodiorito Ibirité, datado por U-Pb (zircão) em $2.698 \pm 18 \mathrm{Ma}$ (Chemale Jr. et al. 1993).

Os granitos Santa Luzia e General Carneiro são corpos de derivação crustal, possivelmente originados da fusão da crosta TTG. Para o Granito General Carneiro, as altas razões Rb/Sr e razão incial ${ }^{87} \mathrm{Sr} /{ }^{86} \mathrm{Sr}$ muito elevada sugerem também a contribuição de material supracrustal. $\mathrm{O}$ granito é intrusivo em uma faixa vulcano-sedimentar encravada no Complexo Belo Horizonte.

O evento de intrusão dos plutonitos neoarqueanos associa-se a uma re-homogeneização isotópica regional do sistema $\mathrm{Rb}-\mathrm{Sr}$ no Gnaisse Belo Horizonte, conforme demonstrado por duas idades isocrônicas no intervalo $2.700-2.600 \mathrm{Ma}$. Os plutonitos exibem foliação bem desenvolvida, parcialmente transposta por zonas de cisalhamento associadas à deformação do 
Supergrupo Minas. As evidências estruturais e o registro isotópico $\mathrm{Rb}-\mathrm{Sr}$ indicam que o Complexo Belo Horizonte foi afetado por um novo evento de deformação, possivelmente em sincronia com o plutonismo granitóide.

No Paleoproterozóico, o Complexo Belo Horizonte foi afetado de forma significativa pelo Evento Transamazônico, registrado pelo sistema isotópico $\mathrm{U}-\mathrm{Pb}$ nas titanitas do Gnaisse Belo Horizonte e mobilizado migmatítico. As análises de titanita definiram a idade de $2.041 \pm 5 \mathrm{Ma}$ para o pico metamórfico do Evento Transamazônico. Uma idade K-Ar em biotita de um veio pegmatítico, de $1.797 \pm 95 \mathrm{Ma}$, poderia marcar o resfriamento final desse evento.

O processo de retrabalhamento do Complexo Belo Horizonte, durante o Evento Transamazônico, deve estar relacionado à deformação principal do Supergrupo Minas.

Análises Rb-Sr em amostras do Granito General Carneiro forneceram uma errócrona de $1.740 \pm 53 \mathrm{Ma}$. O processo de abertura da Bacia Espinhaço iniciou-se nessa mesma época (e.g. Machado et al. 1989b, Almeida-Abreu 1993). É provável que o processo extensional tenha provocado a reativação de zonas de cisalhamento pretéritas, como as que cortam o Granito General Carneiro, re-equilibrando parcialmente o sistema isotópico $\mathrm{Rb}-\mathrm{Sr}$ deste corpo. A presença de diques máficos a noroeste do Complexo Belo Horizonte, com idades K-Ar em torno de $1.700 \mathrm{Ma}$ (Teixeira et al. 1988), reforça a hipótese de reativações da crosta no início do Ciclo Espinhaço, na região estudada.

As demais idades K-Ar (biotita) para o Complexo Belo Horizonte variam entre $1.600 \mathrm{e}$ 1.100 Ma. Estas idades devem refletir eventos ligados à evolução do Ciclo Espinhaço e/ou desequilíbrios isotópicos causados pelo efeito termal do Evento Brasiliano. De qualquer forma, fica bem evidenciada a baixa magnitude desse último evento no domínio do Complexo Belo Horizonte. 


\section{PLUTONITOS GRANITÓIDES (E PEGMATITOS) ARQUEANO TARDIO E PROTEROZÓICO}

\subsection{INTRODUÇÃO}

Corpos intrusivos de caráter granitóide são comuns no âmbito dos complexos metamórficos do Quadrilátero Ferrífero (e.g. Carneiro 1992). Entretanto, nenhum desses corpos mostra relações intrusivas claras com as unidades maiores de rochas supracrustais, como os supergrupos Rio das Velhas e Minas. Contatos diretos são sempre de natureza tectônica. Uma excessão a esta regra foi descrita na Serra do Curral, limite setentrional do Quadrilátero Ferrifero, onde um pequeno plug granítico ocorre circunscrito em rochas do Grupo Sabará (Pomerene 1964). Este corpo foi selecionado para estudo geocronológico, juntamente com outro corpo muito semelhante encontrado a norte, já no domínio do Complexo Belo Horizonte.

Outros dois corpos granitóides selecionados provêm da região meridional do Quadrilátero Ferrífero. Um deles exibe relações claramente intrusivas com o pacote vulcano-sedimentar que se estende a sul da Falha do Engenho (limite meridional do Quadrilátero Ferrifero), pacote este que é correlacionável ao Supergrupo Rio das Velhas (e.g. Grossi Sad et al. 1983). Foi também amostrado um veio quartzo-feldspático (com monazita) intrusivo nessa unidade, no domínio da Falha do Engenho. O segundo corpo granitóide está em contato tectônico com a unidade basal do Supergrupo Minas (Formação Moeda). No mesmo local, os quartzitos da Formação Moeda são injetados por pegmatitos (Guild 1957), que foram amostrados para determinação geocronológica.

\subsection{GRANITO MORRO DA PEDRA E GRANITO CÓRREGO DO BRUMADO (REGIÃO SETENTRIONAL DO QUADRILÁTERO FERRÍFERO)}




\subsubsection{Aspectos Geológicos}

Estes corpos apresentam dimensões reduzidas e foliação incipiente. Sua localização é mostrada na figura 6 (seção 4.2) O Granito Morro da Pedra (Pomerene 1964, Herz 1970) possui dimensões aflorantes da ordem de poucas centenas de metros. Trata-se de granito leucocrático, de granulação média, praticamente não foliado. Ocorre circunscrito em xistos do Grupo Sabará, mas as relações de contato não estão expostas. Pomerene (1964) descreveu uma elevação do grau metamórfico nos xistos encaixantes, atribuindo caráter intrusivo ao Granito Morro da Pedra. A deformação muito incipiente registrada pelo corpo também favorece essa interpretação.

O Granito Córrego do Brumado posiciona-se no contato entre os gnaisses e uma das faixas de supracrustais do Complexo Belo Horizonte. Apresenta cor cinza-clara, granulação média a grossa, com dimensões aflorantes de, aproximadamente, $200 \mathrm{~m}$. Está mais deformado que o Granito Morro da Pedra, chegando a desenvolver foliação.

\subsubsection{Petroquímica}

O Granito Morro da Pedra apresenta textura equigranular hipidiomórfica, exibindo proporções semelhantes de plagioclásio e $\mathrm{K}$-feldspato. $\mathrm{O}$ primeiro encontra-se bastante saussuritizado. O K-feldspato (microclina e ortoclásio) é quase sempre pertítico. O mineral máfico é biotita, bastante subordinada e, em parte, transformada para mica branca. Petrograficamente, o Granito Córrego do Brumado difere pouco, salvo pela maior proporção de K-feldspato em relação ao plagioclásio. Este encontra-se menos alterado e exibe grãos zonados, enquanto o $\mathrm{K}$-feldspato pode formar cristais maiores ricos em inclusões. A deformação, nos dois corpos, é pouco pronunciada, manisfestando-se por feições como microfraturamento do feldspato e poligonização do quartzo.

Em termos de composição química (Tabela 11), o Granito Morro da Pedra é mais potássico, com razões $\mathrm{K}_{2} \mathrm{O} / \mathrm{Na}_{2} \mathrm{O}$ em torno de 1,5. O Granito Córrego do Brumado tem conteúdo em $\mathrm{Na}_{2} \mathrm{O}$ mais elevado e apresenta razão $\mathrm{K}_{2} \mathrm{O} / \mathrm{Na}_{2} \mathrm{O}$ igual a 1 . Ambos os corpos são peraluminosos. O Granito Morro da Pedra é mais enriquecido em ETR, mas as curvas normalizadas de distribuição desses elementos são, marcantemente, semelhantes para os dois plutonitos. São caracterizadas por um extremo empobrecimento em ETRP em relação às ETRL (Figura 22a). A anomalia negativa de Eu é menos acentuada no Granito Córrego do Brumado $\left(\mathrm{Eu}_{\mathbb{N}} / \mathrm{Eu}_{*}=0,521\right)$ que no Granito Morro da Pedra( $\left.\mathrm{Eu}_{\mathbb{N}} / \mathrm{Eu}_{*}=0,367\right)$. 
Tabela 11: Composições químicas do Granito Morro da Pedra (I e 2) e Granito Córrego do Brumado (3)

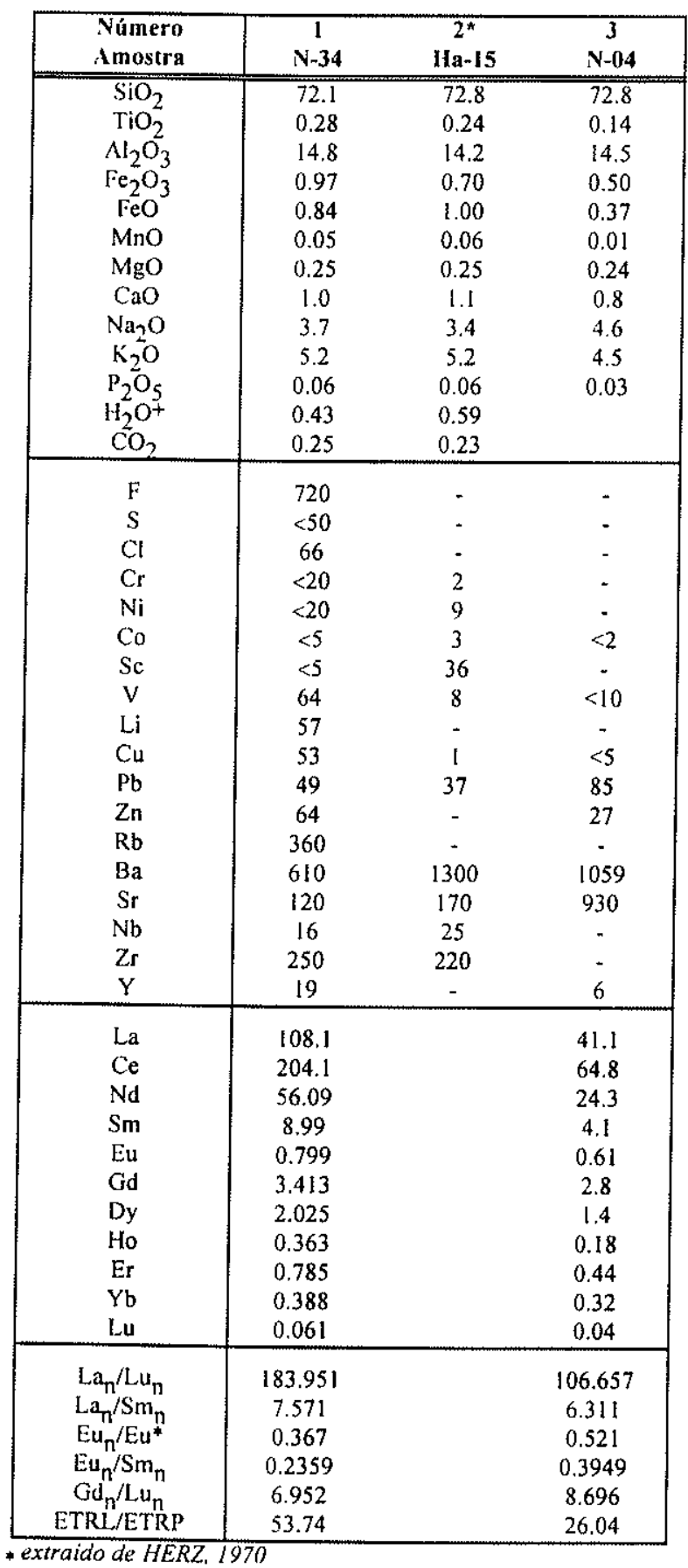


O Gnaisse Belo Horizonte é enriquecido em ETRP em relação aos granitos Morro da Pedra e Córrego do Brumado (Figura 22b), sendo improvável que estes tenham derivado de um processo de fusão parcial do gnaisse. Por outro lado, as curvas de ETR dos granitos assemelhamse à curva média dos granitóides gerados por fusão de sedimentos (e.g. Grossi Sad \& Dutra 1989). A nível especulativo, em especial no caso do Granito Morro da Pedra, este poderia ter sido gerado pela fusão da própria pilha sedimentar do Grupo Sabará.
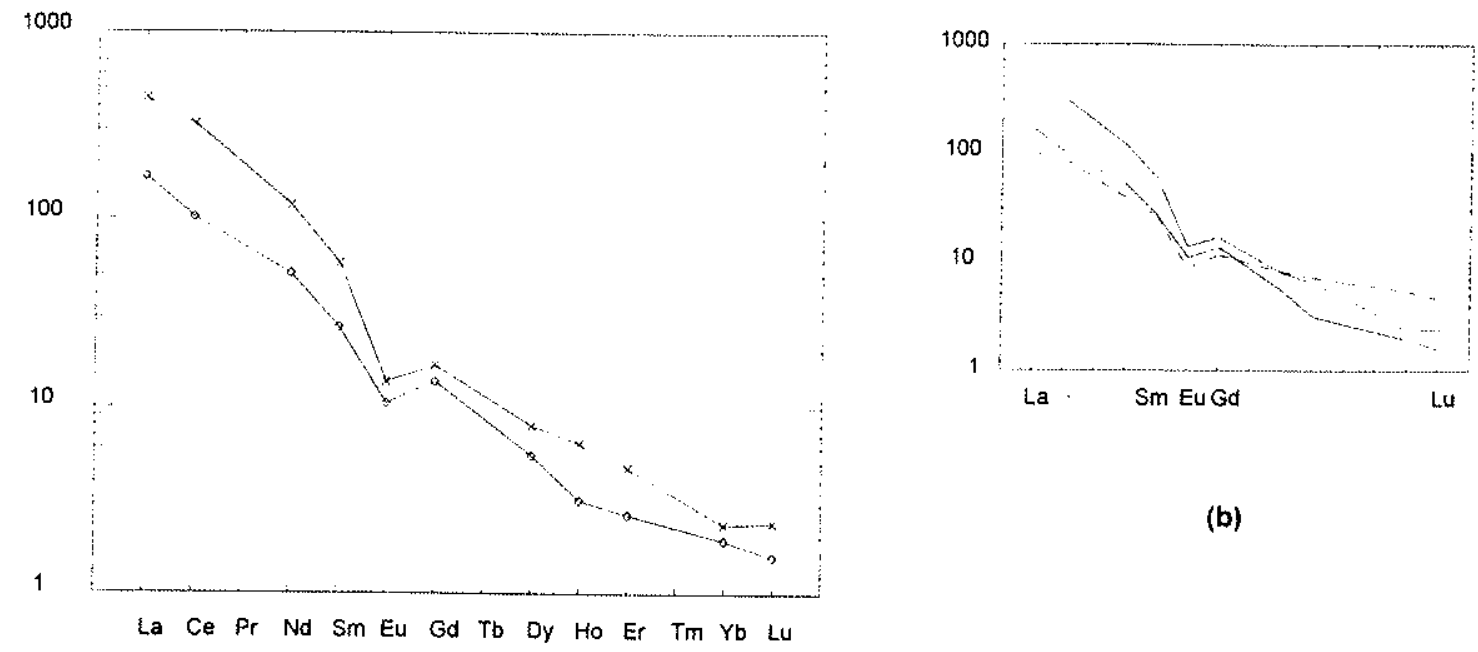

(b)

(a)

Figura 22: (a) Curvas de Etr, normalizadas para condritos (valores de normalização de Jensen et al. 1978) para o Granito Morro da Pedra (xis) e Granito Córrego do Brumado (círculos). (b) Diagrama comparativo das curvas de ETR para os granitos Morro da Pedra e Córrego do Brumado (linha cheia) e a curva média para o Gnaisse Belo Horizonte (linha tracejada).

\subsubsection{Geocronologia}

\subsubsection{Determinaç̃es U-Pb:}

O Granito Morro da Pedra (amostra N-34) continha unicamente zircões alterados. muito magnéticos, retidos nas frações $0,5 \mathrm{~A}$ magnética e não magnética do "Frantz Inicial". Nos grãos da fração não magnética foi possivel observar porções frescas por sob a capa de alteração. 
Alguns destes foram selecionados e atacados por HF diluído. Ao microscópio, observa-se que a porção alterada dissolve-se rapidamente, partindo-se o grão em vários fragmentos. Estes fragmentos foram então levados à abrasão. Após a abrasão, resultaram grãos de cor rosa e outros

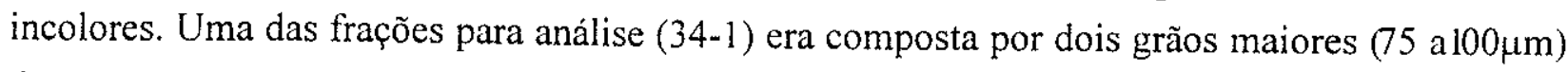
de cor rosa, sem zonamento visível e livres de fraturas ou inclusões. A outra fração continha cinco grãos, dois incolores e três mostrando porções incolores e rosa.

A fração $34-1$ possui idade ${ }^{207} \mathrm{~Pb} / 206 \mathrm{~Pb}$ de $2.682 \mathrm{Ma}, 3,2 \%$ discordante. O erro é elevado devido ao alto $\mathrm{Pb}$ comum (303pg). A fração 34-2 apresenta idade mínima de $2.770 \mathrm{Ma}, 10 \%$ discordante (Tabela 12, Figura 23). Como já havia sido previsto, devido à presença de fragmentos de cor diversa, esta fração possuía população mista, resultando, no caso, na idade mais antiga.

Os resultados obtidos não são conclusivos quanto à idade do plutonito. Ainda que os zircões sejam de idade arqueana, a população analisada continha grãos com diferentes idades de geração. Desta forma, parte ou toda a população era, necessariamente, constituída por zircões herdados.

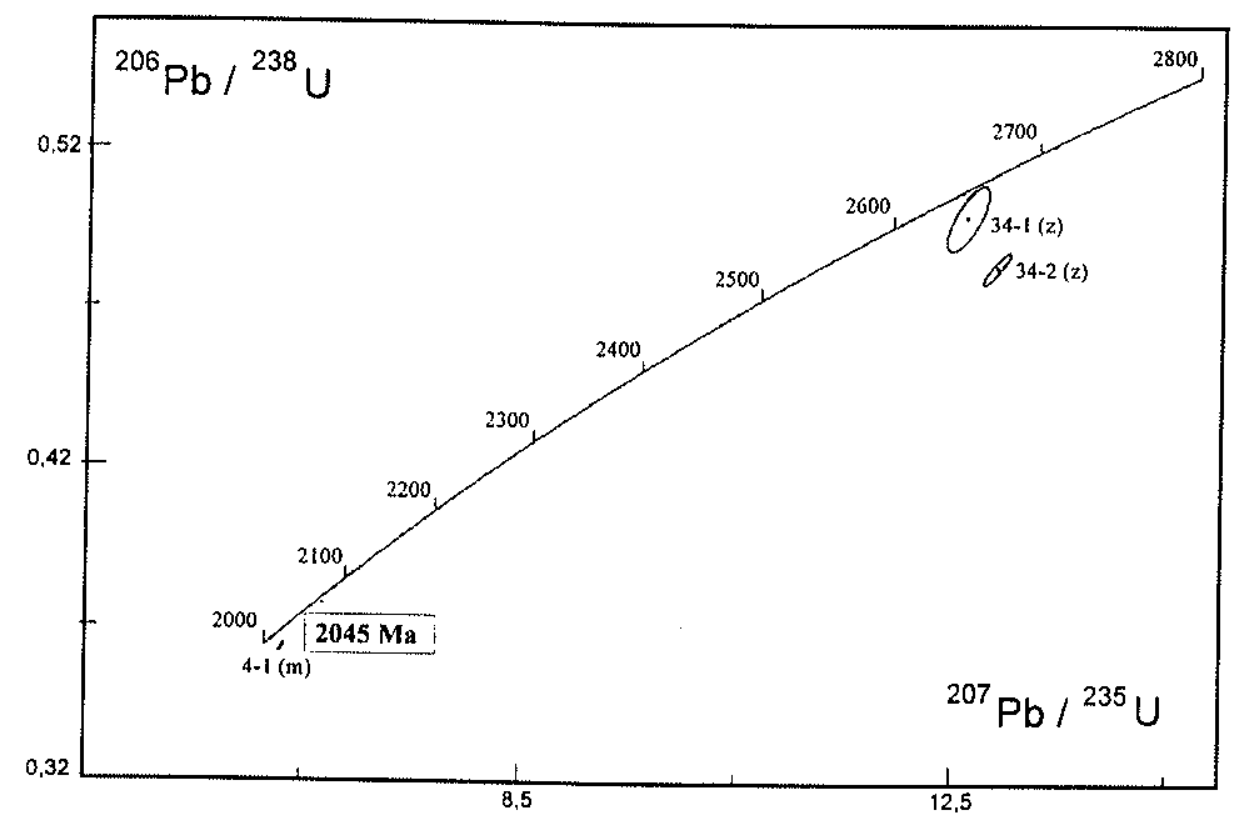

Figura 23: Diagrama concórdia exibindo os dados obtidos para o Granito Morro da Pedra (amostra N-34) e Granito Córrego do Brumado (amostra N-4).

Legenda: $z=$ zircão; $m=$ monazita. 
Tabela 12: Resultados analíticos U-Pb para os granitos Morro da Pedra e Córrego do Brumado

Amostra

Granito Morro da Pedra (amostra N-34)

\begin{tabular}{|c|c|c|c|c|c|c|c|c|c|c|c|c|c|c|c|}
\hline $\begin{array}{c}N^{\circ} \mathrm{da} \\
\text { amostra }\end{array}$ & $\underset{* 1}{M}$ & $\begin{array}{c}\text { Prop. } \\
\text { mag.*2 }\end{array}$ & $\begin{array}{l}N^{\circ} \text { de } \\
\text { grãos }\end{array}$ & $\begin{array}{l}\text { Peso } \\
\text { (mg) }\end{array}$ & $\begin{array}{r}\text { Urânio } \\
(\mathrm{ppm})^{* 3}\end{array}$ & $\begin{array}{c}\text { Pb rad. } \\
(\mathrm{ppm})^{* 3}\end{array}$ & $\begin{array}{c}\mathrm{Pb} \text { com. } \\
(\mathrm{pg})^{* 4}\end{array}$ & $\begin{array}{c}{ }^{206} \mathrm{~Pb} /{ }^{204} \mathrm{~Pb} \\
\end{array}$ & $\begin{array}{c}{ }^{208} \mathrm{~Pb} /{ }^{206} \mathrm{~Pb} \\
{ }^{* 6}\end{array}$ & $\begin{array}{c}{ }^{206} \mathrm{~Pb} /{ }^{238} \mathrm{U} \\
* 6\end{array}$ & $\begin{array}{c}{ }^{207} \mathrm{~Pb} /{ }^{235} \mathrm{U} \\
* 6\end{array}$ & $\begin{array}{c}{ }^{207} \mathrm{~Pb} /{ }^{206} \mathrm{~Pb} \\
\end{array}$ & ${ }^{206} \mathrm{~Pb} /{ }^{238} \mathrm{U}$ & ${ }^{207} \mathrm{~Pb} /{ }^{235} \mathrm{U}$ & ${ }^{207} \mathrm{p} \mathrm{b} /{ }^{206} \mathrm{~Pb}$ \\
\hline $\begin{array}{l}34-1 \\
34-2\end{array}$ & $\begin{array}{l}Z \\
Z\end{array}$ & $\begin{array}{l}\text { IF } \\
\text { IF }\end{array}$ & $\begin{array}{l}2 \\
5\end{array}$ & 0,007 & 130 & 82 & 303 & 108 & 0,2722 & 0,49949 & 12,617 & 0,18320 & 2612 & 2651 & 2682 \\
\hline $34-2$ & & & & 0,007 & 143 & 85 & 104 & 307 & 0,2325 & 0,48374 & 12,889 & 0,19325 & 2544 & 2672 & 2770 \\
\hline
\end{tabular}

Granito Córrego do Brumado (amostra N-04)

\begin{tabular}{|c|c|c|c|c|c|c|c|c|c|c|c|c|c|c|c|}
\hline $\begin{array}{c}\begin{array}{c}N^{0} \text { da } \\
\text { amostra }\end{array} \\
90-04\end{array}$ & $\operatorname{Min}_{* 1}$ & $\begin{array}{c}\text { Prop. } \\
\text { mag.*2 }\end{array}$ & $\begin{array}{l}N^{\circ} \text { de } \\
\text { grãos }\end{array}$ & $\begin{array}{l}\text { Peso } \\
\text { (mg) }\end{array}$ & $\begin{array}{c}\text { Urânio } \\
(\mathrm{ppm})^{* 3}\end{array}$ & $\begin{array}{c}\text { Pb rad. } \\
(\mathrm{ppm})^{* 3}\end{array}$ & $\begin{array}{c}\mathrm{Pb} \text { com. } \\
(\mathrm{pg})^{* 4}\end{array}$ & $\begin{array}{c}{ }^{206} \mathrm{~Pb} /{ }^{204} \mathrm{~Pb} \\
* 5\end{array}$ & $\begin{array}{c}{ }^{208} \mathrm{~Pb} /{ }^{206} \mathrm{~Pb} \\
6\end{array}$ & $\begin{array}{c}{ }^{206} \mathrm{~Pb} /{ }^{238} \mathrm{U} \\
* 6\end{array}$ & $\begin{array}{c}{ }^{207} \mathrm{~Pb} /{ }^{235} \mathrm{U} \\
* 6\end{array}$ & $\begin{array}{c}{ }^{207} \mathrm{~Pb}^{206} \mathrm{~Pb} \\
* 6\end{array}$ & ${ }^{206} \mathrm{~Pb} /{ }^{238} \mathrm{U}$ & ${ }^{207} \mathrm{~Pb} /{ }^{235} \mathrm{U}$ & ${ }^{207} \mathrm{pb}^{206} \mathrm{~Pb}$ \\
\hline & $M$ & IF & 4 & 0,009 & 3241 & 7489 & 763 & $8 \overline{88}$ & 6,2167 & 0,36331 & 6,319 & 0,12614 & 1998 & 2021 & 2045 \\
\hline
\end{tabular}

* 1- Z=zircão, M=monazita.

*2- Propriedades magnéticas: NM/M, não magnético/magnético no ângulo indicado de inclinação do separador magnético FRANTZ, a $1,8 \mathrm{~A}$ e $0^{\circ}$ de inclinação lateral; $1 \mathrm{~F}$,

*3- Concentraçōes são conhecidas com precisão de $2 \%$ para amostras pesando $0,4 \mathrm{mg}, 10-20 \%$ para amostras abaixo de $0,020 \mathrm{mg}$. Para amostras cujo peso está abaixo da

sensibilidade da balança, $0,00 \mathrm{lmg}$, as concentrações listadas são valores máximos.

*4- $\mathrm{Pb}$ comum total corrigido para o $\mathrm{Pb}$ comum do spike.

*5-Razão medida, corrigida apenas para o fracionamento.

*6- Razões corrigidas para o spike, fracionamento, branco e $\mathrm{Pb}$ comum inicial.
Razōes Isotópicas 
O Granito Córrego do Brumado (amostra N-4) apresentava zircões em prismas grandes. muito alterados, ou prismas límpidos mas muito pequenos, pouco adequados para a análise U-Pb. Da fração 1,7A do "Frantz Inicial" foram separados quatro grãos de monazita, pequenos, dois deles inclusos em cristais de apatita. Estes últimos foram liberados durante a abrasão. A análise da fração de monazita forneceu uma idade $207 \mathrm{~Pb} / 206 \mathrm{~Pb}$ de $2.045 \mathrm{Ma}, 2,3 \%$ discordante (Tabela 11, Figura 23).

A monazita é um mineral bastante adequado para datar cristalização de corpos ígneos. Sua temperatura de bloqueio para a difusão do $\mathrm{Pb}$ foi estimada em $725 \pm 25^{\circ} \mathrm{C}$ (Copeland et al. 1988), situando-se na faixa das temperaturas médias das fusões graníticas. Portanto, a ocorrência de monazita restítica (com $\mathrm{Pb}$ herdado) é muito mais rara que de zircão, cuja temperatura de bloqueio é mais elevada (Parrish 1990). Já o resetting ou crescimento de monazita durante o metamorfismo é, geralmente, associado a eventos de alto grau (e.g. Heaman \& Parrish 1991, Childe et al. 1993), ainda que evidências de perturbação do sistema isotópico em eventos de baixa temperatura tenham sido relatados (e.g. Corfu 1987, 1988).

O Granito Córrego do Brumado encontra-se muito pouco deformado, inclusive preservando parcialmente a textura ígnea original. Desta forma, a idade de monazita deve datar a sua cristalização, em torno de $2.045 \mathrm{Ma}$.

\subsubsection{Determinacões $\mathrm{Pb}-\mathrm{Pb}$}

Foi separada uma fração de K-feldspato do Granito Morro da Pedra para análises $\mathrm{Pb}-\mathrm{Pb}$ em lixiviado e resíduo, segundo o procedimento descrito na seção 2.3. A fração de K-feldspato foi submetida a um processo duplo de lixiviação, inicialmente por $\mathrm{HCl} 6 \mathrm{~N}$ (lixiviado $\mathrm{L}_{1}$ ) e, em seguida, por $\mathrm{HF}+\mathrm{HBr}$ (lixiviado $\mathrm{L}_{2}$ ). As razões isotópicas obtidas para os dois lixiviados e o resíduo são apresentadas na tabela 13 . O lixiviado $L_{1}$ apresenta razões isotópicas bem mais elevadas que $L_{2}$, o qual, por sua vez, exibe razões semelhantes às do resíduo (R). Isto demonstra que a primeira lixiviação removeu quase todo o $\mathrm{Pb}$ radiogênico. Como as razões isotópicas do lixiviado $\mathrm{L}_{2}$ são algo maiores que as do resíduo, certa quantidade de $\mathrm{Pb}$ radiogênico deve ter sido removida na segunda lixiviação, visto ser a capacidade de dissolução de $\mathrm{HF}+\mathrm{HBr}$ mais efetiva que a do $\mathrm{HCl}$.

O urânio, na maioria dos casos, está praticamente ausente no $\mathrm{K}$-feldspato, de forma que o $\mathrm{Pb}$ contido neste mineral é muito pouco radiogênico. Comparando-se as razões isotópicas obtidas neste estudo com 48 análises de resíduo e lixiviado de K-feldspato, apresentadas por Corfu (1988) e Carignan et al. (1993b), em apenas um dos casos o lixiviado era tão radiogênico quanto 
o da amostra do Granito Morro da Pedra. Os valores elevados para o lixiviado $L_{1}$ podem ser devidos a várias causas, dentre elas a presença de inclusões de minerais com razões U/Pb elevadas. De fato, o estudo em lâmina delgada revelou que o K-feldspato apresentava inclusões de apatita e allanita. Outra possível razão estaria na natureza pertítica do K-feldspato do Granito Morro da Pedra. Housh \& Bowring (1991) demostraram que as lamelas de exsolução de albita constituem reservatórios de $\mathrm{Pb}$ radiogênico dentro do $\mathrm{K}$-feldspato.

Tabela 13: Razões isotópicas do Pb para o K-feldspato do Granito Morro da Pedra.

\begin{tabular}{|cccc|}
\hline Fração & ${ }^{206} \mathrm{~Pb} / 204 \mathrm{~Pb}$ & $207 \mathrm{~Pb} / 204 \mathrm{~Pb}$ & $208 \mathrm{~Pb} / 204 \mathrm{~Pb}$ \\
\hline \hline $\mathrm{L}_{1}$ & 28,724 & 17,022 & 52,551 \\
$\mathrm{~L}_{2}$ & 16,342 & 15,314 & 36,609 \\
$\mathrm{R}$ & 15,616 & 15,167 & 35,651 \\
\hline
\end{tabular}

Nota: $\mathrm{L}_{1}=1^{\mathrm{a}}$ lixiviação por $\mathrm{HCl} 6 \mathrm{~N} ; \mathrm{L}_{2}=2^{\mathrm{a}}$ lixiviação por $\mathrm{HF}+\mathrm{HBr} ; \mathrm{R}=$ resíduo.

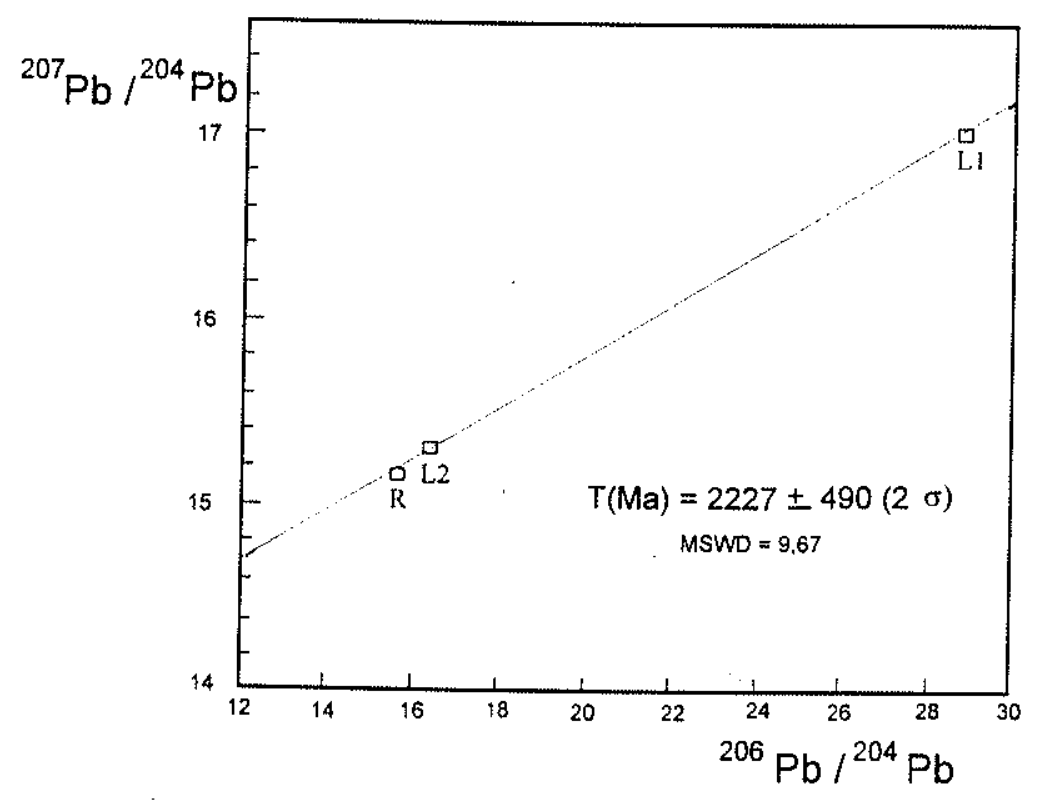

Figura 24: Diagrama isocrônico Pb-Pb para o Granito Morro da Pedra.

Legenda: ver tabela 13. 
A regressão pelas três análises obtidas forneceu uma idade de $2.227 \pm 449 \mathrm{Ma}$, com MSWD de 9,67 (Figura 24). Esta pode ser considerada como uma idade minima para a cristalização do Granito Morro da Pedra. Os valores de $\mu$, avaliados dentro de uma evolução em múltiplos estágios, resultaram muito elevados, indicando a origem crustal do corpo.

\subsubsection{Discussão dos resultados}

O Granito Morro da Pedra apresenta um perfil de ETR muito distinto daqueles dos granitos neoarqueanos do Complexo Belo Horizonte (seção 4.3.2., figura 14a), mas similar ao do Granito Córrego do Brumado. Outro fator que o distingue dos granitos arqueanos é a deformação incipiente. Também nisto o Granito Morro da Pedra assemelha-se ao Granito Córrego do Brumado, reforçando a hipótese de contemporaneidade dos dois corpos. Nesse caso, os zircões arquenos do Granito Morro da Pedra seriam todos xenocristais.

A idade provável de intrusão do Granito Córrego do Brumado, ca. $2.045 \mathrm{Ma}$, coincide com o pico metamórfico do Evento Transamazônico, registrado pelas titanitas do Gnaisse Belo Horizonte. Aventa-se a hipótese de o Granito Morro da Pedra ter-se originado, durante esse evento, por processo de fusão da pilha sedimentar do Grupo Sabará. Marschak et al. (1992) já haviam demonstrado que o metamorfismo desta unidade atingiu níveis de anatexia, com a geração de pequenas lentes granitóides.

\subsection{GRANITÓIDES E PEgMATITOS DA REGIÃO MERIDIONAL DO QUADRILÁTERO FERRÍFERO}

\subsubsection{Aspectos geológicos}

A estruturação da região sul do Quadrilátero Ferrifero é condicionada pela Falha do Engenho. Esta mega-sutura orienta-se em torno de E-W até paralelizar-se com o falhamento da borda ocidental do Sinclinal Moeda (Falha de Moeda), assumindo então rumo SW. O conjunto formado pelas falhas do Engenho e Moeda define os limites de três terrenos geológicos distintos (Figura 25). A norte, o Quadrilátero Ferrifero propriamente dito, com o Supergrupo Minas e seu embasamento granito-greenstone. A sul, ocorrem as faixas tipo greenstone belt de Conselheiro 
Lafaiete, injetadas por plutonitos de composição tonalítica predominante (Distrito Manganesifero de Conselheiro Lafaiete). A oeste, estende-se um terreno gnássico semelhante aos outros complexos arqueanos da região, como os de Bonfim e Belo Horizonte.

Os dois últimos terrenos foram alvo de estudos geocronológicos. Uma descrição mais detalhada das áreas investigadas é apresentada nas próximas seções.

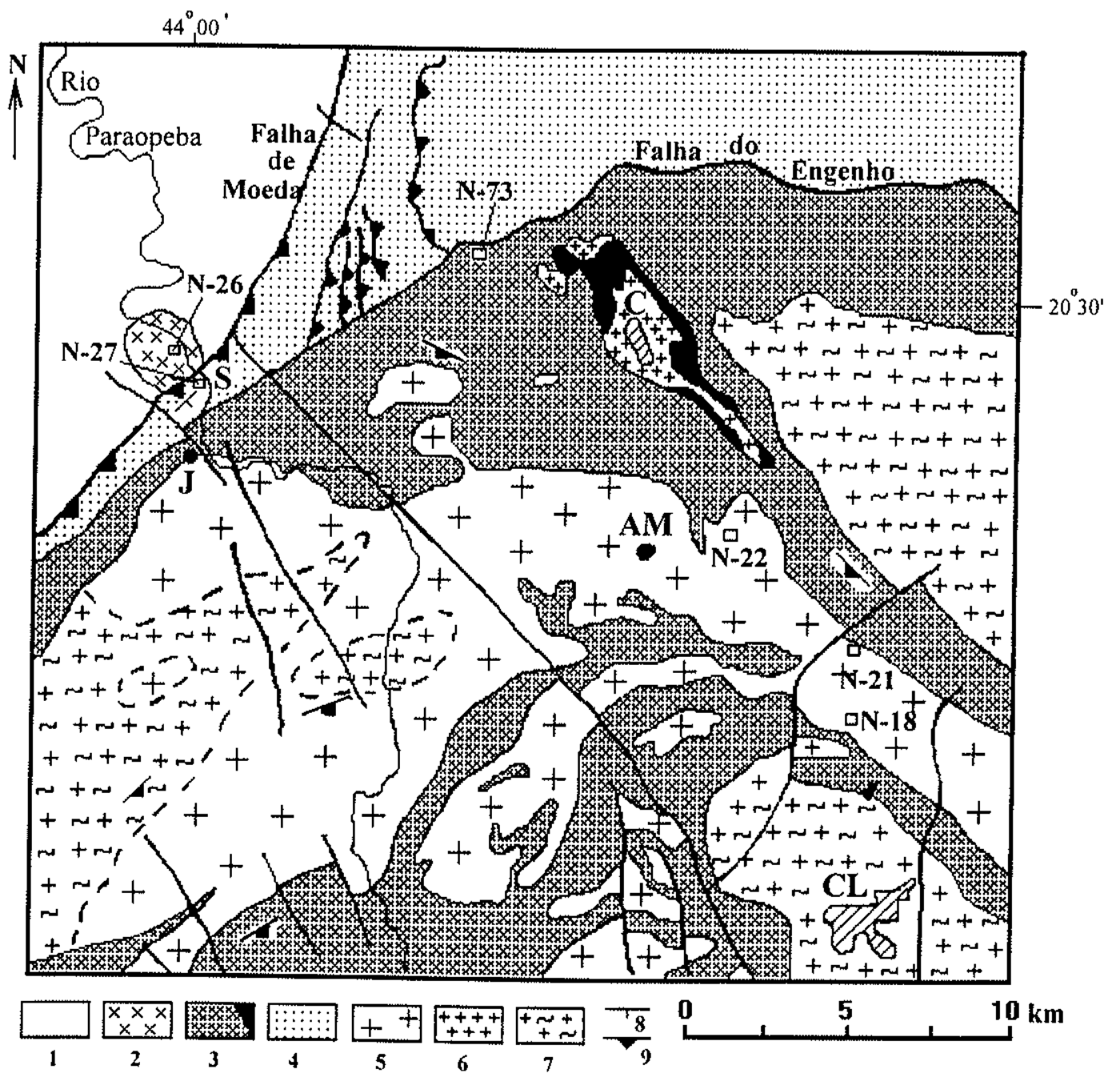

Figura 25: Mapa geológico da região meridional do Quadrilátero Ferrífero (modificado de Grossi Sad et al. 1983)

Legenda: I - Complexo gnáissico arqueano: 2 - Granito Salto do Paraopeba; 3 - Grupo Nova Lima (ultramáficas em preto); 4-Supergrupo Minas; 5 - Batólito Alto Maranhão; 6 - Tonalito de Congonhas; 7 - Migmatitos; 8 acamamento; 9 -foliação principal. Localidades: CL - Conselheiro Lafaiete; C - Congonhas do Campo: AM - Alto Maranhão; J - Jeceaba; $S$ - Salto do Paraopeba. ( N-22 - amostragem para geocronologia) 


\subsubsection{Região de Salto do Paraopeba}

Salto do Paraopeba designa uma queda d'água que se segue ao fundo vale entalhado pelo Rio Paraopeba, ao cortar a extremidade sudoeste da Serra da Moeda. A serra é a expressão topográfica do Supergrupo Minas, que forma uma faixa estreita, com cerca de $1,5 \mathrm{~km}$ de largura. orientada segundo NE-SW. Suas rochas mergulham entre $50^{\circ}$ e $60^{\circ}$ para SE.

Uma seção estratigráfica detalhada dos grupos Caraça e Itabira (Supergrupo Minas) nesta área foi apresentada por Guild (1957). Os quartzitos da Formação Moeda possuem espessura em torno de $100 \mathrm{~m}$, seguidos pelos filitos da Formação Batatal, com $35 \mathrm{~m}$ de espessura. O Grupo Itabira é constituído, essencialmente, por itabiritos com intercalações dolomíticas, alcançando $175 \mathrm{~m}$ de espessura. A unidade superior, Grupo Piracicaba, encontra-se mal exposta. É composta por filitos sericíticos com intercalações de quartzitos, frequentemente ferruginosos, além de lentes de dolomito. Esta descrição aplica-se às formações Cercadinho e Fecho do Funil, não individualizadas no trabalho de Guild (1957). O mesmo autor descreve a presença de um nível de metatufos, ocorrendo cerca de $2 \mathrm{~km}$ a leste de Salto do Paraopeba, em uma localidade conhecida como Esmeril. Trata-se de uma rocha quartzo-sericítica, xistosa e de grão fino, contendo grãos de quartzo azulados (1-2mm), arredondados a subédricos. Ao microscópio, constata-se que alguns cristais de quartzo exibem golfos de corrosão. Na matriz, destacam-se pseudomorfos de feldspato, totalmente sericitizados. Estas feições confirmam a natureza vulcânica desta rocha, constituíndo-se em uma das raríssimas ocorrências comprovadas de metavulcanitos no Supergrupo Minas. Uma tentativa de datação $\mathrm{U}-\mathrm{Pb}$ do metatufo não foi bem sucedida, visto serem os zircões muito raros e de péssima qualidade.

Junto à base da Formação Moeda, no corte da estrada de ferro em Salto do Paraopeba, ocorrem quatro corpos de pegmatito caolinizado, de forma tabular e encaixados segundo os planos de estratificação do quartzito. Sua espessura varia entre 10 e $50 \mathrm{~cm}$, apresentando-se foliados e boudinados. Mineralogicamente, são constituídos por quartzo, microclina (plagioclásio subordinado), muscovita, biotita, hornblenda fortemente pleocróica e turmalina (Guild 1957).

O contato do Quartzito Moeda com as rochas do complexo gnáissico a oeste é de natureza tectônica; quartzito e gnaisse estão fortemente cisalhados e chegam a mostrar-se imbricados, o que é observado pouco a norte de Salto do Paraopeba. A foliação milonítica possui atitude em torno de N55W/50SE, com lineação de estiramento a S75E. Observando a figura 25, fica evidente o posicionamento da faixa do Supergrupo Minas entre os prolongamentos da Falha do Engenho e Falha de Moeda. A primeira apresenta movimentação final de natureza transcorrente destral, ao longo de sua extensão orientada E-W (Romano et al. 1992). Como, na região de Salto do Paraopeba, a falha inflete para SW, deve-se esperar um componente de movimento para W, 
que teria provocado o embricamento da faixa do Supergrupo Minas entre o complexo gnáissico e o bloco de Conselheiro Lafaiete.

O terreno gnaíssico a oeste de Salto do Paraopeba é muito pouco estudado. Segundo Guild (1957) é composto por gnaisses bem foliados, de aspecto bandado, cuja composição mineralógica mostra tanto a predominância de plagioclásio como de microclina. biotita constituíndo o máfico principal. As exposições estudadas exibiam feições de migmatização. Em suma, as características do gnaisse são muito semelhantes às dos gnaisses mais antigos, tanto do Complexo Belo Horizonte como do Complexo Bonfim.

Guild (1957) constatou a ocorrência de dois pequenos corpos graníticos intrusivos nos gnaisses. Um deles foi estudado no presente trabalho, estando exposto no corte da ferrovia em Salto do Paraopeba. O granito, doravante designado Granito Salto do Paropeba, está em contato direto com o Quartzito Moeda, apresentando aspecto milonítico na zona de contato. A medida que se afasta desta, exibe porções homófanas alternadas com faixas cisalhadas. As dimensões do Granito Salto do Paropeba são da ordem de $3-4 \mathrm{~km}$.

\subsubsection{Distrito Manganesifero de Conselheiro Lafaiete}

A região exibe uma sequiência supracrustal contendo depósitos de manganês, razão pela qual há muito tem despertado a atenção dos geólogos. Esta sequiência foi incluida na "Série" Barbacena de Barbosa $(1949,1954)$ e, posteriormente, separada como Formação Lafaiete por Ebert (1957). Guild (1957) adotou a designação Greenschist Sequence, considerando duvidosa sua posição estratigráfica, embora se inclinasse por uma correlação com a "Série" Minas. Já Dorr et al. (1957) propuseram a equivalência com a "Série" Rio das Velhas do Quadrilátero Ferrífero. Considerando o caráter vulcano-sedimentar da seqüência em causa, uma correlação com o Grupo Nova Lima da "Série" Rio das Velhas seria mais precisa. Esta posição foi adotada por autores como Grossi Sad et al. (1983) e será seguida neste trabalho.

Além dos trabalhos citados, descrições do Grupo Nova Lima na região de Conselheiro Lafaiete podem ser encontrados em Pires (1977), Pinto \& Duarte (1978), Barbosa (1985), Seixas (1988), dentre outros. As rochas da unidade distribuem-se em algumas faixas maiores, de formato irregular, faixas menores de forma lenticular, pequenos corpos e roof pendants em plutonitos granitóides, além de inclusões em migmatitos (Pires 1977). Apresenta um horizonte muito característico, constituído por formação manganesífera sílico-carbonatada (gondito e queluzito), somado a raros e descontínuos niveis de formação ferrifera. Abaixo deste pacote, e perfazendo a maior parte da seqüência, ocorrem xistos de composição variada (derivados de rochas sedimentares pelíticas e grauvaqueanas) e anfibolitos. Inclui também rochas meta- 
ultramáficas, com destaque para o corpo de esteatito, serpentinito e talco xisto da área de Congonhas do Campo.

O Grupo Nova Lima foi injetado por um extenso corpo granitóide que recebeu a designação Batólito Alto Maranhão (Grossi Sad et al. 1983). A Falha do Engenho marca o limite norte desta intrusão. O carater ígneo do batólito é claramente evidenciado, especialmente nas zonas de contato. As rochas do Grupo Nova Lima são cortadas por diques do granitóide ou estão inclusas como xenólitos. Observaram-se, inclusive, "bolsões" ricos em xenólitos angulosos, em forma de blocos, sugerindo mecanismo de intrusão por stoping. Em extensas áreas, representadas na figura 25, a intrusão gerou migmatitos de injeção, tornando impossível separar, em mapa, as rochas supracrustais do corpo ígneo (Guild 1957, Grossi Sad et al. 1983).

Exposições do Batólito Alto Maranhão mostram a presença de mais de uma fase intrusiva. Estudo detalhado por Barbosa (1985) demonstra que a massa plutônica exibe um trend de diferenciação tonalito (trondhjemito)-granodiorito, sendo cortada por diques, concordantes ou não, e aplitos, injetados em fases diversas da evolução magmática. Desta forma, as várias fases graníticas (s.l.) seriam, essencialmente, co-magmáticas (Barbosa 1985).

Embora possa conter porções homófanas, o Batólito Alto Maranhão possui, caracteristicamente, foliação bem desenvolvida, podendo apresentar-se intensamente cisalhado. O posicionamento da intrusão é considerado sin-cinemático (Pires 1977).

Junto à cidade de Congonhas do Campo ocorre outro corpo intrusivo, de composição trondhjemítica (Seixas 1988), circunscrito por rochas do Grupo Nova Lima. Muito provavelmante, faz parte da mesma suíte intrusiva do Batólito Alto Maranhão, fato já sugerido por Herz (1970).

A estruturação do Distrito Manganesífero de Conselheiro Lafaiete é marcada pela forma em arco das faixas do Grupo Nova Lima, com concavidade voltada para sul. Os elementos planares principais, tanto nas rochas do Grupo Nova Lima como nos plutonitos, acompanham essa estruturação, rotacionando de uma posição NE-SW para NW-SE, com mergulhos fortes para dentro do arco (Grossi Sad et al. 1983). Seixas (1988) e Nummer et al. (1992) apresentaram estudo estrutural daquele segmento orientado NW-SE, designado Lineamento Congonhas. Os autores descrevem uma história evolutiva complexa, associada a movimentos fortemente oblíquos segundo direção em torno de S60E.

A evolução da estruturação regional e o papel exercido pela Falha do Engenho e Lineamento Congonhas serão discutidos ao final deste capítulo, à luz dos dados isotópicos. 


\subsubsection{Petroquímica}

\subsubsection{Granito Salto do Paraopeba}

Trata-se de um granito leucocrático de cor branca acinzentada, com granulação média a fina. Uma análise modal desta rocha é apresentada por Guild (1957): quartzo-30\%; microclina$31 \%$; oligoclásio-36\%; biotita-1,5\%; muscovita-1\% (provém da alteração da biotita); acessórios0,5\%. Em seção delgada, apresenta textura inequigranular hipidiomórfica, evidenciando-se a deformação pela presença de zonas de cisalhamento milimétricas, com forte cominuição dos grãos.

Duas análises químicas desta rocha estão apresentadas na tabela 14. A amostra representada pela análise $n^{\circ} 2$ é mais rica em $\mathrm{SiO}_{2}$, mais pobre em $\mathrm{CaO}$ e possui razão $\mathrm{K}_{2} \mathrm{O} / \mathrm{Na}_{2} \mathrm{O}$ mais elevada. Exibe também maior diferenciação nos ETR e anomalia negativa de Eu mais acentuada (Figura 26). As diferenças entre as análises das duas amostras parecem refletir um processo de cristalização fracionada. A anomalia negativa de Eu, maior na amostra da análise $\mathrm{n}^{\circ} 2$, sugere maior proporção de plagioclásio em equilíbrio com o líquido e, portanto, um estágio mais avançado da cristalização fracionada. Esta assertiva é reforçada pelo decréscimo no conteúdo em Sr e Ba na mesma amostra, já que estes elementos também tenderiam a ficar retidos no plagioclásio.

O Granito Salto do Paraopeba é ligeiramente peraluminoso e, à semelhança dos granitos neoarqueanos do Complexo Belo Horizonte, pode ter sido gerado pela refusão de rochas tonalíticas-granodioriticas.

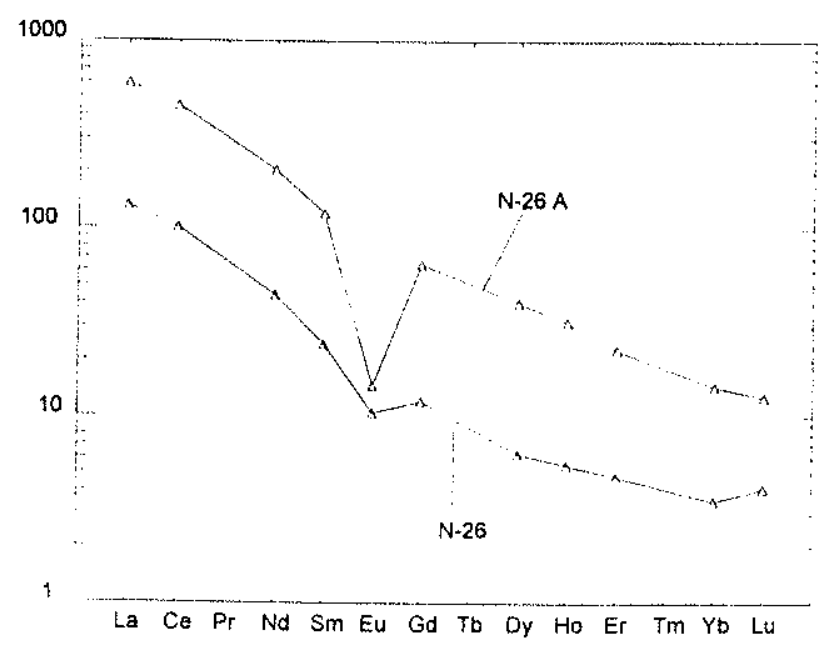

Figura 26: Curvas de ETR, normalizadas para condritos (valores de normalização de Jensen et al. 1978), para o Granito Salto do Paraopeba. 
Tabela 14: Composições químicas do Granito Salto do Paraopeba (l e 2) e do Batólito Alto Maranhão (3 e 4)

\begin{tabular}{|c|c|c|c|c|}
\hline $\begin{array}{l}\text { Número } \\
\text { Amostra } \\
\end{array}$ & $\begin{array}{c}1 \\
\mathrm{~N}-26 \\
\end{array}$ & $\begin{array}{c}2 \\
N-26 A \\
\end{array}$ & $\begin{array}{c}3 \\
N-18 \\
\end{array}$ & $\begin{array}{c}4 \\
N-22 \\
\end{array}$ \\
\hline $\begin{array}{c}\mathrm{SiO}_{2} \\
\mathrm{TiO}_{2} \\
\mathrm{Al}_{2} \mathrm{O}_{3} \\
\mathrm{Fe}_{2} \mathrm{O}_{3} \\
\mathrm{FeO} \\
\mathrm{MnO} \\
\mathrm{MgO} \\
\mathrm{CaO} \\
\mathrm{Na}_{2} \mathrm{O} \\
\mathrm{K}_{2} \mathrm{O} \\
\mathrm{P}_{2} \mathrm{O}_{5} \\
\mathrm{PF} \\
\end{array}$ & $\begin{array}{c}72.7 \\
0.21 \\
14.8 \\
0.19 \\
1.0 \\
0.02 \\
0.41 \\
1.5 \\
4.1 \\
4.2 \\
0.07 \\
0.52 \\
\end{array}$ & $\begin{array}{c}74.4 \\
0.22 \\
13.4 \\
0.58 \\
1.1 \\
0.02 \\
0.17 \\
0.80 \\
3.4 \\
5.1 \\
0.06 \\
0.49 \\
\end{array}$ & $\begin{array}{c}68.8 \\
0.45 \\
15.4 \\
1.8 \\
1.3 \\
0.05 \\
1.0 \\
3.3 \\
4.8 \\
1.8 \\
0.17 \\
0.80 \\
\end{array}$ & $\begin{array}{c}65.3 \\
0.75 \\
13.9 \\
0.85 \\
3.1 \\
0.08 \\
3.0 \\
4.4 \\
4.1 \\
2.2 \\
0.31 \\
1.19 \\
\end{array}$ \\
\hline $\begin{array}{c}\mathrm{F} \\
\mathrm{S} \\
\mathrm{Cl} \\
\mathrm{Cr} \\
\mathrm{Ni} \\
\mathrm{V} \\
\mathrm{Cu} \\
\mathrm{Pb} \\
\mathrm{Zn} \\
\mathrm{Rb} \\
\mathrm{Ba} \\
\mathrm{Sr} \\
\mathrm{Nb} \\
\mathrm{Zr} \\
\mathrm{Y} \\
\end{array}$ & $\begin{array}{c}410 \\
<50 \\
<20 \\
- \\
- \\
12 \\
2 \\
23 \\
43 \\
180 \\
880 \\
290 \\
<5 \\
200 \\
24 \\
\end{array}$ & $\begin{array}{c}350 \\
<50 \\
39 \\
- \\
- \\
<10 \\
2 \\
93 \\
77 \\
360 \\
350 \\
67 \\
34 \\
420 \\
120 \\
\end{array}$ & $\begin{array}{c}620 \\
190 \\
54 \\
- \\
- \\
51 \\
12 \\
28 \\
61 \\
49 \\
1030 \\
780 \\
6 \\
290 \\
18 \\
\end{array}$ & $\begin{array}{c}1200 \\
<50 \\
49 \\
- \\
- \\
87 \\
16 \\
74 \\
69 \\
52 \\
1350 \\
930 \\
9 \\
400 \\
34 \\
\end{array}$ \\
\hline $\begin{array}{l}\mathrm{La} \\
\mathrm{Ce} \\
\mathrm{Nd} \\
\mathrm{Sm} \\
\mathrm{Eu} \\
\mathrm{Gd} \\
\mathrm{Dy} \\
\mathrm{Ho} \\
\mathrm{Er} \\
\mathrm{Yb} \\
\mathrm{Lu} \\
\end{array}$ & $\begin{array}{l}32.400 \\
64.920 \\
20.900 \\
3.743 \\
0.605 \\
2.460 \\
1.603 \\
0.312 \\
0.793 \\
0.585 \\
0.105 \\
\end{array}$ & $\begin{array}{c}144.600 \\
285.890 \\
95.820 \\
18.470 \\
0.845 \\
13.230 \\
10.250 \\
1.810 \\
3.768 \\
2.376 \\
0.320 \\
\end{array}$ & $\begin{array}{c}25.650 \\
56.690 \\
22.650 \\
4.073 \\
0.922 \\
2.688 \\
1.931 \\
0.394 \\
1.101 \\
0.841 \\
0.131\end{array}$ & $\begin{array}{c}52.660 \\
111.200 \\
49.570 \\
9.148 \\
2.133 \\
5.739 \\
3.868 \\
0.712 \\
1.624 \\
1.194 \\
0.172 \\
\end{array}$ \\
\hline $\begin{array}{c}\mathrm{La}_{\mathrm{n}} / \mathrm{Lu}_{\mathrm{n}} \\
\mathrm{La}_{\mathrm{n}} / \mathrm{Sm}_{\mathrm{n}} \\
\mathrm{Eu}_{\mathrm{n}} / \mathrm{Eu}^{*} \\
\mathrm{Eu}_{\mathrm{n}} / \mathrm{Sm}_{\mathrm{n}} \\
\mathrm{Gd} \mathrm{n}_{\mathrm{n}} / \mathrm{Lu}_{\mathrm{n}} \\
\text { ETRL/ETRP }\end{array}$ & $\begin{array}{c}32.030 \\
5.450 \\
0.574 \\
0.429 \\
2.912 \\
20.916\end{array}$ & $\begin{array}{c}46.906 \\
4.929 \\
0.158 \\
0.122 \\
5.138 \\
17.183\end{array}$ & $\begin{array}{c}20.325 \\
3.965 \\
0.802 \\
0.601 \\
2.550 \\
15.522 \\
\end{array}$ & $\begin{array}{c}31.780 \\
3.624 \\
0.840 \\
0.619 \\
4.147 \\
16.884 \\
\end{array}$ \\
\hline
\end{tabular}




\subsubsection{Batólito Alto Maranhão}

As amostras representativas do Batólito Alto Maranhão mostram composição tonalítica, a mineralogia essencial constituída por plagioclásio (oligoclásio), quartzo, biotita e anfibólio (hornblenda e actinolita). A textura predominante é granoblástica bem orientada embora, em algumas amostras, textura ignea do tipo inequigranular hipidiomórfica encontre-se parcialmente preservada.

Em termos de composição química (Tabela 14), o corpo tem caráter metaluminoso, constituíndo um granitóide do tipo I na classificação de Chapell \& White (1974). As curvas de ETR (Figura 27) mostram fracionamento em ETRL maior que em ETRP, anomalia negativa de Eu insignificante $\left(\mathrm{Eu}_{\mathrm{N}} / \mathrm{Eu}_{*}>0,8\right)$ e conteúdo total de ETR moderado. Segundo Grossi Sad \& Dutra (1989) estas são características dos granitóides tipo de sintexis com fonte mista, derivados da fusão de rochas máfico-ultramáficas da placa oceânica e sua cobertura sedimentar. A presença de zircão herdado em amostra do Batólito Alto Maranhão (seção 5.3.3.3) é indicativa de que algum volume de sedimento pode ter estado envolvido no processo magmático que gerou o batólito.

Especulativamente, pode-se fazer algumas comparações com corpos cordilheiranos fanerozóicos, como o Batólito Peninsula Ranges (Baixa Califórnia). Este engloba dois grupos de plutonitos, quimicamente distintos, dispostos paralelamente em relação à fossa. Segundo o modelo discutido por Leake (1990), o grupo mais próximo à fossa deriva, exclusivamente, da fusão da cunha mantélica, induzida pelos fluidos liberados pela placa oceânica em subducção. A partir de profundidades superiores a $45 \mathrm{~km}$, a própria placa oceânica começa a fundir, resultando no segundo grupo de plutonitos. O Batólito Alto Maranhão é muito semelhante, quimicamente, aos plutonitos mais distantes da fossa.

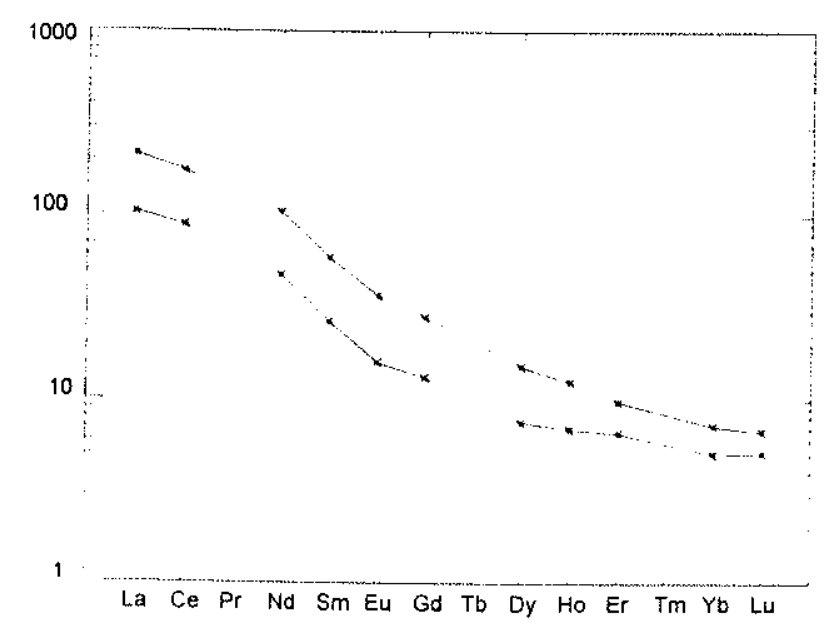

Figura 27: Curvas de ETR, normalizadas para condritos, (valores de normalização de Jensen et al. 1978), para o Batólito Alto Maranhão. 
As análises foram lançadas no diagrama discriminante R1xR2 de Batchelor \& Bowden (1985) e naqueles de Pearce et al. (1984). O registro dos dados mostra posicionamento no campo dos granitos pré-colisionais e granitos de arco vulcânico, reforçando a hipótese da geração do Batólito Alto Maranhão em ambiente de margem continental ativa.

\subsubsection{Geocronologia}

A localização das amostras com determinações geocronológicas, para a região meridional do Quadrilátero Ferrífero, é encontrada na figura 25.

\subsubsection{Granito Salto do Paraopeba (amostra N-26): Determinações U-Pb}

Foram separados dois zircões da fração M1 do "Frantz Final". Estes prismas eram grandes e do tipo achatado, com arestas bem definidas. Exibiam fraturas transversais atravessando o cristal, o que é indicativo da ausência de núcleo. A amostra continha mais duas populações distintas de zircão, uma composta por prismas curtos e pequenos e a outra por núcleos rosa com sobrecrescimento incolor, frequentemente alterados.

Cada um dos prismas selecionados foi partido em vários fragmentos, divididos em duas frações para análise. As frações 26-1 e 26-2, derivadas de um dos prismas, tinham idades mínimas semelhantes, em torno de 2.608 Ma, 3\% discordantes. As frações 26-4 e 26-6, derivadas do outro prisma, eram mais pobres em $U$ e bem mais discordantes, respectivamente 15 e $19 \%$. Esta diferença deve estar ligada ao tempo de abrasão, $8 \mathrm{~h} 30 \mathrm{~min}$ para as frações 26-1 e 26-2 e $5 \mathrm{~h}$ para as demais. Os quatro pontos definem uma discórdia com probabilidade de ajuste de $87 \%$, a idade do intercepto superior igual a $2.612 \pm 5 \mathrm{Ma}$ (Tabela 15, Figura 28).

As características dos zircões analisados sugeriam tratar-se de cristais gerados no processo de cristalização da rocha, em constraste com outros grãos observados onde a presença de núcleo (herança) era evidente. Considerando ainda o excelente arranjo linear dos pontos de análise, a idade do intercepto superior é a melhor estimativa para a idade de cristalização do granito. $O$ intercepto inferior, com idade de $372 \mathrm{Ma}$, deve refletir a difusão de $\mathrm{Pb}$ a baixas temperaturas. 
Tabela 15: Resultados analiticos $U-P b$, região meridional do Quadrilátero Ferrífero.

Amostra

Granito Salto do Paraopeba (amostra N-26)

\begin{tabular}{|c|c|c|c|}
\hline $\begin{array}{l}\mathrm{N}^{\circ} \mathrm{da} \\
\text { amostra }\end{array}$ & $\underset{* 1}{\text { Min. }}$ & $\begin{array}{l}\text { Prop. } \\
\text { mag.*2 }\end{array}$ & $\begin{array}{l}N^{\circ} \text { de } \\
\text { grãos }\end{array}$ \\
\hline $26-1$ & $\bar{Z}$ & $\mathrm{M} 1$ & 1 \\
\hline $26-2$ & $Z$ & MI & I \\
\hline $26-4$ & Z & M1 & 1 \\
\hline $26-6$ & $z$ & M1 & 1 \\
\hline
\end{tabular}

26-6 $\quad Z \quad M 1 \quad 1 \quad$ np

Pegmatito de Salto do Paraopeba (amostra N-27)

\begin{tabular}{|c|c|c|c|c|c|c|c|c|c|c|c|c|c|c|c|}
\hline $\begin{array}{c}N^{\circ} \mathrm{da} \\
\text { amostra }\end{array}$ & $\underset{* 1}{\operatorname{Min} .}$ & $\begin{array}{c}\text { Prop. } \\
\text { mag.*2 }\end{array}$ & $\begin{array}{l}N^{\circ} \text { de } \\
\text { grăos }\end{array}$ & $\begin{array}{l}\text { Peso } \\
\text { (mg) } \\
\end{array}$ & $\begin{array}{c}\text { Uränio } \\
(\mathrm{ppm})^{* 3}\end{array}$ & $\begin{array}{c}\text { Pb rad. } \\
(\mathrm{ppm})^{* 3}\end{array}$ & $\begin{array}{c}\mathrm{Pb} \text { com. } \\
(\mathrm{pg})^{* 4}\end{array}$ & $\begin{array}{c}{ }^{206} \mathrm{~Pb} /{ }^{204} \mathrm{~Pb} \\
* 5\end{array}$ & $\begin{array}{c}{ }^{208} \mathrm{~Pb} /{ }^{206} \mathrm{~Pb} \\
* 6\end{array}$ & $\begin{array}{c}{ }^{206} \mathrm{~Pb} /{ }^{238} \mathrm{U} \\
* 6\end{array}$ & $\begin{array}{c}{ }^{207} \mathrm{~Pb} /{ }^{235} \mathrm{U} \\
* 6\end{array}$ & $\underset{* 6}{{ }_{* 6}^{207} \mathrm{~Pb} /{ }^{206} \mathrm{~Pb}}$ & ${ }^{206} \mathrm{~Pb} /{ }^{235} \mathrm{U}$ & ${ }^{207} \mathrm{~Pb} /{ }^{235} \mathrm{U}$ & ${ }^{207} \mathrm{~Pb} / 206 \mathrm{~Pb}$ \\
\hline $\begin{array}{l}27-1 \\
27-2\end{array}$ & $\begin{array}{l}Z \\
z\end{array}$ & M1 & 2 & np & 386 & 201 & 53 & 218 & 0,1883 & 0,44313 & 10,637 & 0,17409 & 2365 & 2492 & 2597 \\
\hline & 2 & M5 & 7 & 0,002 & 255 & 130 & 34 & 430 & 0,1761 & 0,43535 & 11,231 & 0,21400 & 2330 & 2543 & 2677 \\
\hline
\end{tabular}

Batólito Alto Maranhão (amostras N-22 e N-18)

\begin{tabular}{|c|c|c|c|c|c|c|c|c|c|c|c|c|c|c|c|}
\hline $\begin{array}{c}\mathrm{N}^{\circ} \mathrm{da} \\
\text { amostra }\end{array}$ & $\begin{array}{c}\text { Min. } \\
* 1\end{array}$ & $\begin{array}{l}\text { Prop. } \\
\text { mag.*2 }\end{array}$ & $\begin{array}{l}N^{\circ} \text { de } \\
\text { grãos }\end{array}$ & $\begin{array}{l}\text { Peso } \\
(\mathrm{mg}) \\
\end{array}$ & $\begin{array}{c}\text { Urânio } \\
(\mathrm{ppm})^{* 3}\end{array}$ & $\begin{array}{c}\text { Pb rad. } \\
(\mathrm{ppm})^{* 3}\end{array}$ & $\begin{array}{c}\mathrm{Pb} \text { com } \\
(\mathrm{pg})^{* 4}\end{array}$ & $\begin{array}{c}{ }^{206} \mathrm{~Pb} / 204 \\
* 5\end{array}$ & $\underset{* 6}{{ }^{208} \mathrm{~Pb} / 206 \mathrm{~Pb}}$ & $\begin{array}{c}{ }^{206} \mathrm{~Pb} /{ }^{238} \mathrm{U} \\
* 6\end{array}$ & $\underset{* 6}{{ }^{207} \mathrm{~Pb}{ }^{235} \mathrm{U}}$ & $\underset{* 6}{{ }^{207} \mathrm{~Pb} / 206 \mathrm{~Pb}}$ & ${ }^{206} \mathrm{~Pb} /{ }^{23 \mathrm{~S}} \mathrm{U}$ & ${ }^{207} \mathrm{~Pb} /{ }^{235} \mathrm{U}$ & ${ }^{207} \mathrm{~Pb} /{ }^{200} \mathrm{~Pb}$ \\
\hline $22-1$ & $\mathrm{Z}$ & $\mathrm{NM}$ & 3 & 0,004 & 371 & 157 & 13,2 & 2768 & 0,1326 & 0,38779 & 7,078 & 0,13237 & 2113 & 2121 & 2130 \\
\hline $22-2$ & Z & NM & 20 & 0,014 & 139 & 57 & 12,8 & 3663 & 0,1127 & 0,38256 & 7,129 & 0,13516 & 2088 & 2128 & 2166 \\
\hline $22-3$ & $\mathrm{~T}$ & IF & 55 & 0,217 & 156 & 52 & 4504 & 165 & 0,0996 & 0,31717 & 5,775 & 0,13205 & 1776 & 1943 & 2125 \\
\hline $22-4$ & $T$ & If & 40 & 0,162 & 75 & 29 & 784 & 391 & 0,0236 & 0,38493 & 7,001 & 0,13192 & 2099 & 2112 & 2124 \\
\hline 18 & $\mathrm{~T}$ & IF & 40 & 0,188 & 201 & 92 & 561 & 1623 & 0.2722 & 0,38083 & 6,927 & 0,13192 & 2080 & 2102 & 2124 \\
\hline
\end{tabular}

$* 1-Z=z i r c a ̃ o, T=t i t a n i t a$.

*2- Propriedades magnéticas: NM/M, nào magnético/magnético no ângulo indicado de inclinação do separador magnético FRANTZ, a $1,8 \mathrm{~A}$ e $0^{\circ}$ de inclinação lateral; IF, não magnético entre $1,0 \mathrm{~A}$ e $1,8 \mathrm{~A}$ com $10^{\circ}$ de inclinação lateral.

*3- Concentrações são conhecidas com precisão de $2 \%$ para amostras pesando $0,4 \mathrm{mg}, 10-20 \%$ para amostras abaixo de $0,020 \mathrm{mg}$. Para amostras cujo peso está abaixo da sensibilidade da balança, $0,001 \mathrm{mg}$ as concentraçōes listadas são valores máximos.

*4- $\mathrm{Pb}$ comum total corrigido para o $\mathrm{Pb}$ comum do spike.

*5- Razão medida, corrigida apenas para o fracionamento.

*6- Razões corrigidas para o spike, fracionamento, branco e $\mathrm{Pb}$ comum inicial 


\subsubsection{Pegmatito de Salto do Paraopeba (amostra $\mathrm{N}-27$ ): Determinações U-Pb e $\mathrm{Pb}-\mathrm{Pb}$}

Os pegmatitos são intrusivos no quartzito da Formação Moeda, junto ao contato com o Granito Salto do Paraopeba (seção 5.3.1.1.) A amostra continha quantidade muito pequena de minerais pesados, sendo possível separar apenas duas frações de zircão para análise. A fração 27-1 (M1, "Frantz Final") era composta por dois fragmentos de cristais muito pequenos, cor rosa, com arestas bem definidas. A fração 27-2 (M5, "Frantz Final") era composta por sete fragmentos semelhantes aos da fração anterior. $O$ pequeno tamanho dos grãos permitiu que fossem submetidos à abrasão por tempo não superior a $3 \mathrm{~h}$, portanto levando à expectativa de análises bastante discordantes.

A fração $27-1$ apresenta idade ${ }^{207} \mathrm{~Pb} / 206 \mathrm{~Pb}$ de $2.597 \mathrm{Ma}, 11 \%$ discordante, enquanto a fração 27-2 é ainda mais discordante (14\%) e com idade minima de $2.683 \mathrm{Ma}$ (Tabela 15, Figura 28). Não há maneira das frações analisadas alinharem-se em uma discórdia, sugerindo que essas continham zircões gerados em episódios distintos. A fração 27-1 posiciona-se, praticamente, sobre a discórdia de 2.612 Ma do Granito Salto do Paraopeba. Entretanto, o fato não é suficiente para definir esta idade como a dos zircões da fração analisada. As determinações U-Pb não permitem chegar a qualquer conclusão quanto à idade do pegmatito, ressaltando-se apenas o fato de serem arqueanos os zircões analisados.

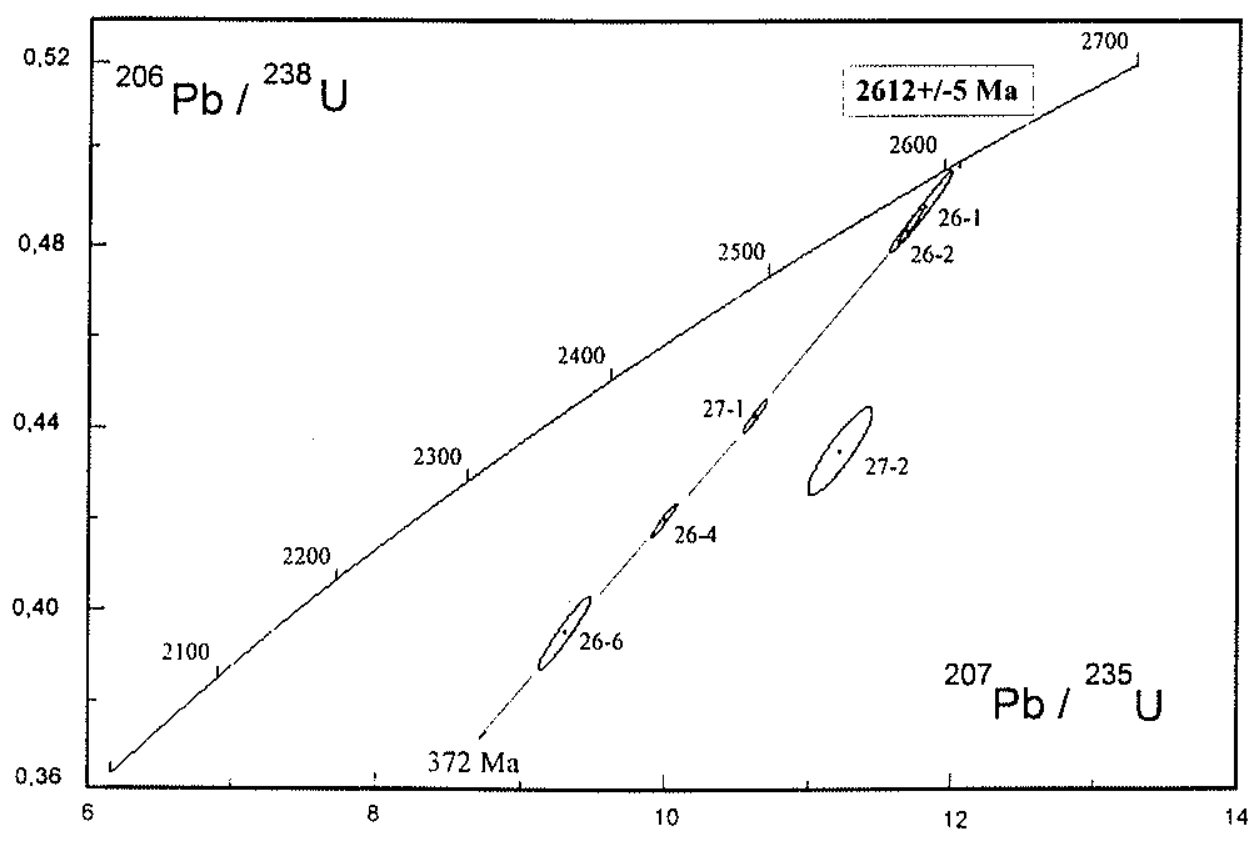

Figura 28: Diagrama concórdia para o Granito Salto do Paraopeba (amostra N-26) e pegmatito intrusivo na Formação Moeda (amostra N-27). Todas as análises são de zircão. 
O pegmatito de Salto do Paraopeba continha abundante anfibólio verde escuro (hornblenda). Foram separadas 4 frações deste mineral, com aproximadamente $10 \mathrm{mg}$ cada, duas provenientes da fração 0,5A do "Frantz Inicial" e as demais das frações 1,0A e 1,7A. As razões isotópicas do $\mathrm{Pb}$ obtidas estão expostos na tabela 16 . A fração $F_{1}$ foi submetida à lixiviação com $\mathrm{HF}+\mathrm{HBr}$ (lixiviado $L_{1}$ ). A fração $\mathrm{F}_{2}$ foi inicialmente lixiviada com $\mathrm{HCl} 6 \mathrm{~N}$ (lixiviado $\mathrm{L}_{2}$ ) e, em seguida, com $\mathrm{HF}+\mathrm{HBr}$ (lixiviado $\mathrm{L}_{2 \mathrm{a}}$ ). Esta lixiviação dupla promoveu a remoção mais efetiva do $\mathrm{Pb}$ radiogênico, de forma que o resíduo $\mathrm{R}_{2}$ apresenta as razões isotópicas menos radiogênicas do conjunto de análises. Estes valores podem ser tomados como os valores máximos para a composição isotópica inicial. Os lixiviados $\mathrm{L}_{1}$ e $\mathrm{L}_{2}$ apresentam composições isotópicas bastante radiogênicas e similares. Já a composição isotópica de $\mathrm{L}_{2 \mathrm{a}}$ é pouco radiogênica, aproximando-se dos valores obtidos para a amostra total $\left(\mathrm{T}_{1}, \mathrm{~T}_{3}\right.$ e $\left.\mathrm{T}_{4}\right)$. Por amostra total entende-se a dissolução completa, em um único lixiviado, a que foi submetida uma parte da fração $F_{1}$ e as frações $F_{3} e$ $\mathrm{F}_{4}$.

Uma regressão através de todos os dados fornece a idade de 1.804 $\pm 110 \mathrm{Ma}$, com MSWD ue 113. Por outro lado, fazendo a regressão somente com os dados de amostra total e resíduo, obtém-se uma idade mais antiga, 2.236 $\pm 200 \mathrm{Ma}$, MSWD igual a 14,9. (Figura 29). Os lixiviados mais radiogênicos posicionam-se abaixo da isócrona mais antiga. Este fato sugere um evento mais novo de perturbação do sistema isotópico. Por exemplo, um evento hidrotermal poderia promover a remoção do $\mathrm{Pb}$ radiogênico do anfibólio, à maneira de uma lixiviação natural. $\mathrm{A}$ idade de $2.236 \pm 200$ Ma pode ser considerada como uma estimativa para a cristalização (ou resetting metamórfico) dos anfibólios. Os dois lixiviados radiogênicos recordariam um evento mais novo, de metamorfismo ou alteração hidrotermal, ocorrendo por volta de $1.800 \mathrm{Ma}$.

Tabela 16: Razões isotópicas do Pb para os anfibólios do pegmatito de Salto do Paraopeba

\begin{tabular}{|cccc|}
\hline Fração & ${ }^{206} \mathrm{~Pb} /{ }^{204} \mathrm{~Pb}$ & $207 \mathrm{~Pb} / 204 \mathrm{~Pb}$ & $208 \mathrm{~Pb} / 204 \mathrm{~Pb}$ \\
\hline \hline $\mathrm{F}_{1} / 0,5 \mathrm{~A}\left(\mathrm{~T}_{1}\right)$ & 28,647 & 17,404 & 40,140 \\
$\mathrm{~F}_{1} / 0,5 \mathrm{~A}\left(\mathrm{~L}_{1}\right)$ & 59,578 & 20,745 & 46,445 \\
$\mathrm{~F}_{1} / 0,5 \mathrm{~A}\left(\mathrm{R}_{1}\right)$ & 23,879 & 16,774 & 39,448 \\
$\mathrm{~F}_{2} / 0,5 \mathrm{~A}\left(\mathrm{~L}_{2}\right)$ & 65,992 & 21,346 & 45,557 \\
$\mathrm{~F}_{2} / 0,5 \mathrm{~A}\left(\mathrm{~L}_{2 \mathrm{a}}\right)$ & 27,064 & 17,237 & 40,876 \\
$\mathrm{~F}_{2} / 0,5 \mathrm{~A}\left(\mathrm{R}_{2}\right)$ & 19,656 & 16,094 & 36,723 \\
$\mathrm{~F}_{3} / 1 \mathrm{~A}\left(\mathrm{~T}_{3}\right)$ & 27,175 & 17,159 & 40,461 \\
$\mathrm{~F}_{4} / 1,7 \mathrm{~A}\left(\mathrm{~T}_{4}\right)$ & 30,06 & 17,562 & 40,167 \\
\hline
\end{tabular}

Nota: $\left(T_{1}, T_{3}\right.$ e $T_{4}=$ análises de amostra total; $L_{1}$ e $L_{2 a}=$ lixiviação com $H F+H B r ; L_{2}=$ lixiviação com $\mathrm{HCl} 6 \mathrm{~N} ; R_{l}$ e $R_{2}=$ residuos) 


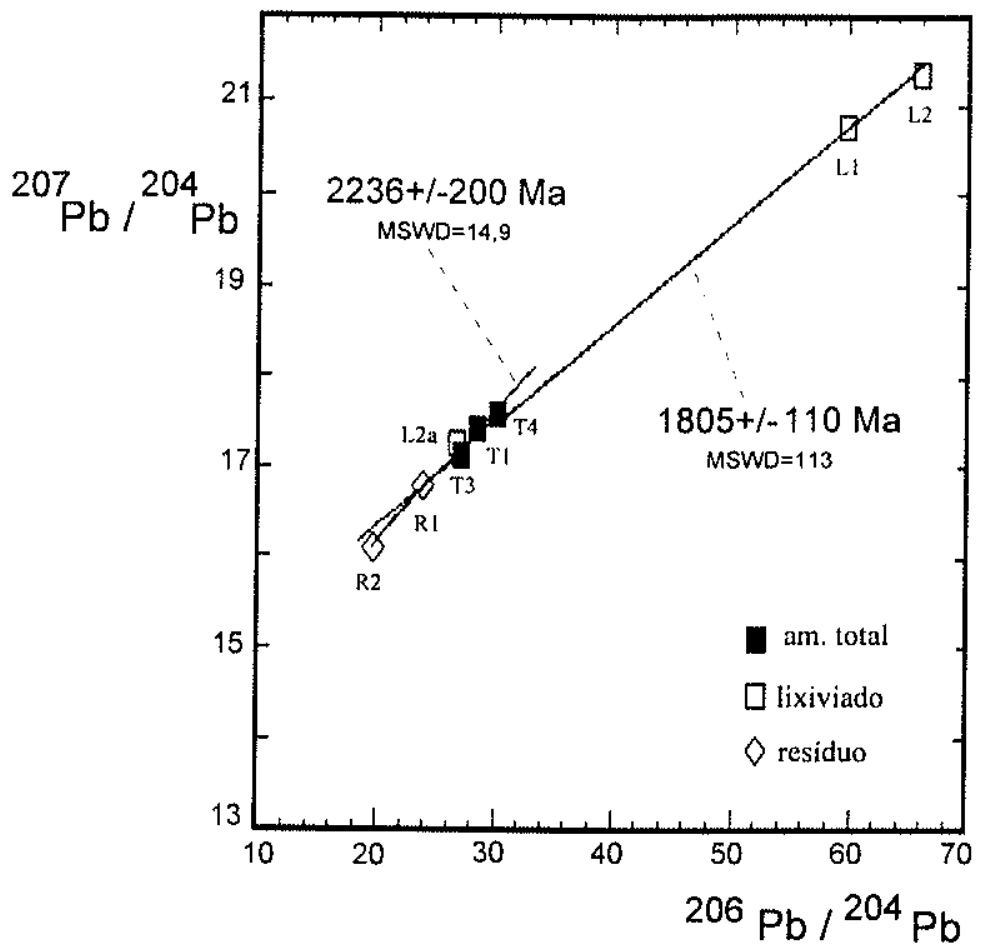

Figura 29: Diagrama isocrônico Pb-Pb para anfibólios do pegmatito de Salto do Paraopeba. Legenda: ver tabela 16.

\subsection{Batólito Alto Maranhão (amostras N-22 e N-18): Determinações U-Pb, Sm-Nd, Rb-Sr e} $\mathrm{K}-\mathrm{Ar}$

A amostra $\mathrm{N}-22$ foi obtida em uma pequena pedreira próxima a localidade de Alto Maranhão. A rocha apresentava granulometria média a grossa e aspecto bastante homogêneo, salvo pela presença de encraves máficos. Possuía abundante zircão de boa qualidade, sem alteração, na fração não magnética do "Frantz Final". A análise tipológica mostrou a presença de três populações de zircão. A primeira era composta por prismas curtos de tamanho variável, cor rosa, superfície lisa e arestas bem definidas (gem quality), sem núcleo oticamente discernível. A segunda exibia prismas pequenos e alongados, rosa claro a incolores. A terceira população consistia de prismas rosa. com superficie rugosa e arestas arredondadas, podendo exibir núcleo mais claro a incolor, sugerindo presença de componente herdado. 
Foram selecionadas duas frações provenientes da primeira população. A fração 22-1 continha três prismas grandes $(\sim 100 \mu \mathrm{m})$ e a fração $22-2$ era composta por vinte prismas

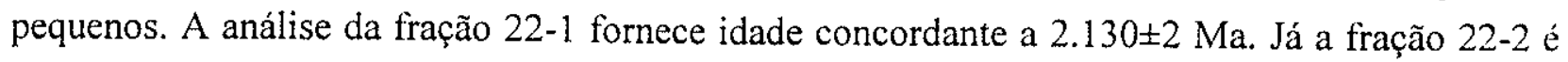
$4 \%$ discordante, com idade mínima de $2.166 \mathrm{Ma}$ (Tabela 15).

A fração M5 do "Frantz Final" continha titanita marron pálida a incolor, de tamanho pequeno e com inclusões frequentes de biotita. Foram separadas duas frações, a primeira sofrendo abrasão por 3 h a 2 psi $(22-3)$ e a segunda não polida (22-4). Uma terceira fração de titanitas foi obtida da amostra $\mathrm{N}-18$, proveniente de uma pedreira localizada em torno de $10 \mathrm{~km}$ do ponto 22, dentro do mesmo corpo intrusivo. As titanitas (fração 18 1) apresentavam coloração marrom, limpas de inclusões. A fração $22-3$ possui idade mínima de $2.125 \mathrm{Ma}$, muito discordante (19\%). A fração $22-4$ é praticamente concordante $(1,35 \%)$ a 2.124 Ma. Curiosamente, a análise muito discordante é da fração submetida à abrasão. A fração 18 -1 é ligeiramente discordante $(2,4 \%)$, igualmente com idade ${ }^{207} \mathrm{~Pb} / 206 \mathrm{~Pb}$ de $2.124 \mathrm{Ma}$.

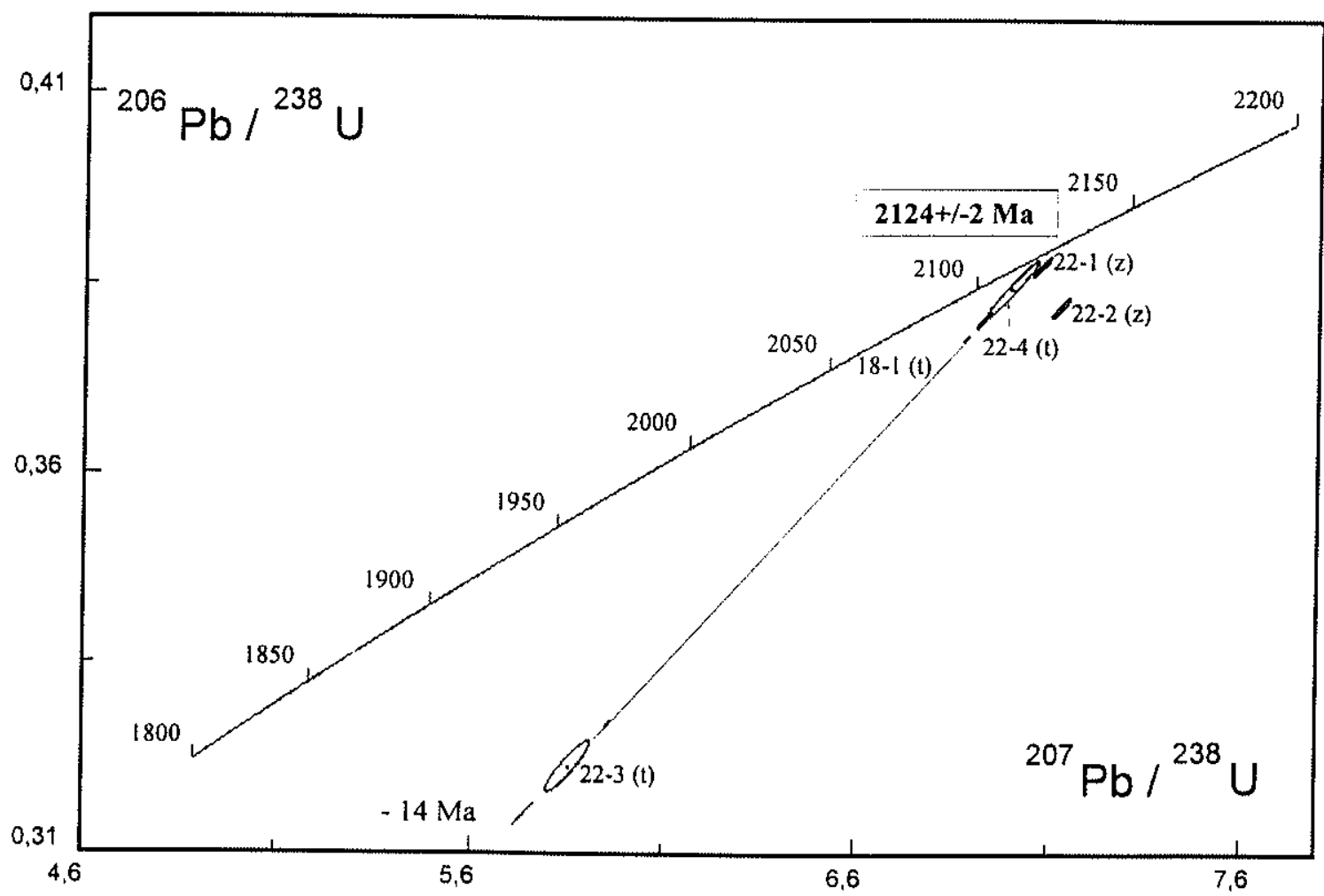

Figura 30: Diagrama concórdia para o Batólito Alto Maranhão (amostras N-22 e N-18). Legenda: $\mathrm{z}=$ zircão, $\mathrm{t}=$ titanita. 
As três análises de titanita alinham-se (probabilidade de ajuste de 97\%) em uma discórdia com intercepto superior a 2.124 $2 \mathrm{Ma}$ (Figura 30). Esta idade é um pouco mais nova que aquela fornecida pela análise concordante de zircão $(2.130 \pm 2 \mathrm{Ma})$ e, possivelmente, reflete o resfriamento do batólito. Considerando as temperaturas de bloqueio estimadas para zircão e titanita (seção 2.6), o corpo teria sofrido resfriamento de $800^{\circ} \mathrm{C}$ para $600-500^{\circ} \mathrm{C}$ em $6 \pm 4 \mathrm{Ma}$. A taxa de resfriamento resultante destes dados é compatível com taxas previstas por modelos teóricos (Fowler \& Nisbet 1982, in: Corfu et al. 1985).

Em conclusão, o valor de $2.124 \pm 2$ Ma é a melhor estimativa para a idade de cristalização do Batólito Alto Maranhão. A idade mínima de $2.166 \mathrm{Ma}$, da fração de zircão 22-2, implica na presença de herança radiogênica. Os grãos deviam preservar, em sua porção mais interna, um componente de $\mathrm{Pb}$ radiogênico antigo, a despeito da ausência de núcleos visiveis.

$\mathrm{O}$ intercepto inferior da discórdia de titanitas aponta para a origem. Portanto, não há evidência de perturbação do sistema isotópico $\mathrm{U}-\mathrm{Pb}$ por algum evento geológico posterior à cristalização. Por outro lado, a elevada discordância da fração de titanita 22-3 sugere processo ecente de perda de $\mathrm{Pb}$.

Foi realizada uma análise Sm-Nd para o Batólito Alto Maranhão, cujos resultados estão expostos na tabela 17. As idades-modelo Sm-Nd (TDM) calculadas são de $2.110 \pm 57 \mathrm{Ma}$ (segundo o método de De Paolo 1988) e $2.119 \pm 57 \mathrm{Ma}$ (segundo o método de Nancy, in: Sato et al. 1994). Essas idades são muito próximas da idade de cristalização definida pelas determinações $\mathrm{U}-\mathrm{Pb}, \mathrm{o}$ que reforça o caráter mantélico do batólito. $\mathrm{O}$ ENd calculado para a idade de cristalização, ca. $2.124 \mathrm{Ma}, \dot{e}+2,45$.

Tabela 17: Dados isotópicos Sm/Nd para o Batólito Alto Maranhão (amostra N-18).

\begin{tabular}{|cccccc|}
\hline $\begin{array}{c}\mathrm{N}^{\circ} \\
\text { Amostra }\end{array}$ & $\begin{array}{c}\mathrm{N}^{\circ} \mathrm{Lab} \\
\text { CPGeo }\end{array}$ & $\begin{array}{c}\mathrm{Sm} \\
\mathrm{ppm}\end{array}$ & $\begin{array}{c}\mathrm{Nd} \\
\mathrm{ppm}\end{array}$ & ${ }^{147} \mathrm{Sm} /{ }^{144} \mathrm{Nd}$ & ${ }^{143 \mathrm{Sm} / 144 \mathrm{Nd}}$ \\
\hline $\mathrm{N}-18 \mathrm{n}$ & 255 & 3,009 & 17,242 & $0,0106180 \pm 0,000051$ & $0,511516 \pm 0,000043$ \\
\hline
\end{tabular}

Foram obtidas duas idades isocrônicas $\mathrm{Rb}$-Sr para o Batólito Alto Maranhão. A amostragem foi feita nas mesmas pedreiras amostradas para U-Pb. Na Pedreira da Prefeitura (ponto N-18), próximo a Gagé, obteve-se uma errócrona com quatro pontos (MSWD=18,2) e idade de $664 \pm 80 \mathrm{Ma}$ (Tabela 18, Figura 31a). Na pedreira próximo à localidade de Alto Maranhão (ponto $\mathrm{N}-22$ ), as análises forneceram uma isócrona ( $M S W D=1$ ) de quatro pontos e idade de $485 \pm 37 \mathrm{Ma}$ (Tabela 18, Figura $31 \mathrm{~b}$ ). 
As idades isocrônicas apontam para um evento de rejuvenescimento isotópico ao final do Proterozóico (Brasiliano), que não é registrado pelo sistema U-Pb. Franciscus Baars (com. verbal) obteve uma isócrona $\mathrm{Rb}-\mathrm{Sr}$, para o batólito, com idade semelhante à idade $\mathrm{U}-\mathrm{Pb}$, a partir de amostras coletadas em diversos afloramentos. Acredita-se que a difusão isotópica do $\mathrm{Sr}$ deu-se em escala de afloramento, sem re-equilibrar o sistema em escala regional. As baixas razões $\mathrm{Rb} / \mathrm{Sr}$ do Batólito Alto Maranhão fazem com que o sistema seja mais facilmente re-equilibrado por difusão isotópica em pequena escala.

As isócronas $\mathrm{Rb}-\mathrm{Sr}$ apresentam razões iniciais ${ }^{87} \mathrm{Sr} /{ }^{86} \mathrm{Sr}$ semelhantes, em torno de 0,707 . A regressão linear pelas razões atuais e iniciais, até a curva de evolução da Terra global, sugere que o protólito do Batólito Alto Maranhão foi extraído do manto entre 2.000 e $2.150 \mathrm{Ma}$, em conformidade com a idade modelo Sm-Nd.

Tabela 18: Dados isotópicos Rb/Sr em rocha total para o Batólito Alto Maranhão, amostras $\mathrm{N}-18$ e $\mathrm{N}-22$.

\begin{tabular}{|cccccc|}
\hline $\begin{array}{c}\mathrm{N}^{\circ} \\
\text { Amostra }\end{array}$ & $\begin{array}{c}\mathrm{N}^{\circ} \mathrm{Lab} \\
\mathrm{CPGeo}\end{array}$ & $\begin{array}{c}\mathrm{Rb} \\
(\mathrm{ppm}\end{array}$ & $\begin{array}{c}\mathrm{Sr} \\
(\mathrm{ppm})\end{array}$ & ${ }^{87} \mathrm{Rb} /{ }^{86} \mathrm{Sr}$ & ${ }^{87} \mathrm{Sr} / 86 \mathrm{Sr}$ \\
\hline \hline $18 \mathrm{~B}$ & 11905 & 54,8 & 571,1 & $0,2780 \pm 0,0080$ & $0,710340 \pm 0,000050$ \\
$18 \mathrm{E}$ & 11906 & 44,3 & 642,5 & $0,2000 \pm 0,0060$ & $0,709500 \pm 0,000070$ \\
$18 \mathrm{I}$ & 11907 & 79,2 & 688,8 & $0,3330 \pm 0,0090$ & $0,710230 \pm 0,000060$ \\
$18 \mathrm{~N}$ & 11908 & 57,5 & 693,1 & $0,2400 \pm 0,0070$ & $0,709390 \pm 0,000060$ \\
\hline $22 \mathrm{~A}$ & 11873 & 53,1 & 815,4 & $0,1890 \pm 0,0050$ & $0,709230 \pm 0,000070$ \\
$22 \mathrm{C}$ & 11874 & 61,9 & 822,4 & $0,2180 \pm 0,0060$ & $0,709260 \pm 0,000090$ \\
$22 \mathrm{D}$ & 11875 & 33,1 & 725,9 & $0,1320 \pm 0,0040$ & $0,708800 \pm 0,000070$ \\
$22 \mathrm{E}$ & 11876 & 62,0 & 510,6 & $0,3520 \pm 0,0100$ & $0,710330 \pm 0,000060$ \\
\hline
\end{tabular}

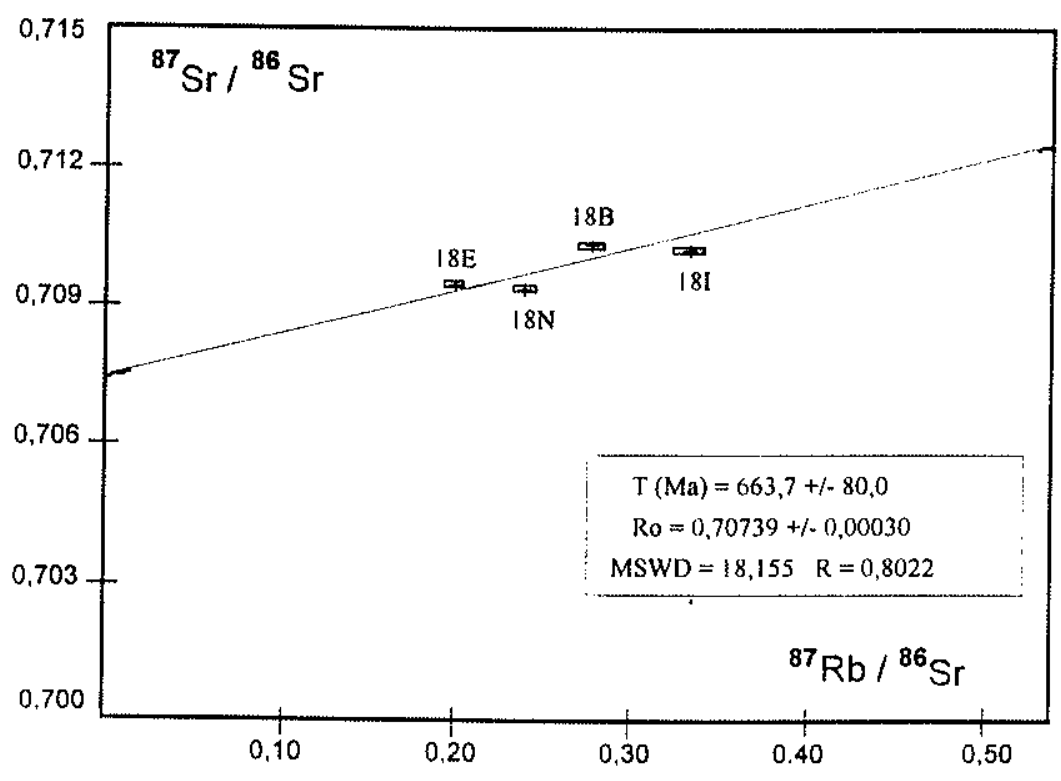

(a)

Figura 31: (continua na página seguinte) 


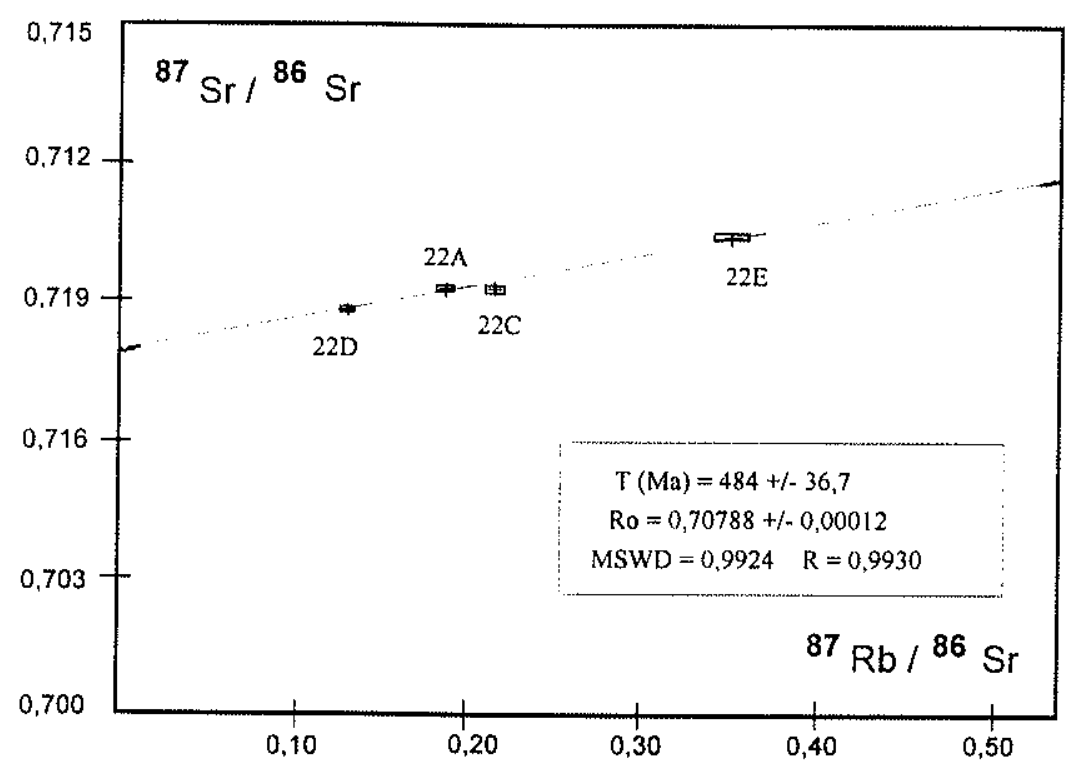

(b)

Figura 31 : Diagramas isocrônicos Rb-Sr em rocha total para o Batólito Alto Maranhão.

(a) amostra N-18; (b) amostra N-22.

Complementando o quadro de determinações geocronológicas para o Batólito Alto faranhão, efetuaram-se duas análises K-Ar em biotita. As idades obtidas, entre 1.000 e $700 \mathrm{Ma}$ (Tabela 19), devem representar idades mistas decorrentes da abertura parcial do sistema isotópico durante o Evento Brasiliano.

Tabela 19: Análises K-Ar em biotita para o Batólito Alto Maranhão (amostras $\mathrm{N}-21$ e $\mathrm{N}-22$ ).

\begin{tabular}{|cccccc|}
\hline $\begin{array}{c}\mathrm{N}^{\circ} \\
\text { Amostra }\end{array}$ & $\begin{array}{c}\mathrm{N}^{\circ} \text { Lab. } \\
\text { CPGeo }\end{array}$ & $\mathrm{K}(\%)$ & $\begin{array}{c}{ }^{40} \mathrm{Ar} \text { atm } \\
(\%)\end{array}$ & $\begin{array}{c}{ }^{40} \mathrm{Ar} \text { rad. } \\
\left(10^{-6}\right. \\
\mathrm{ccSTP} / \mathrm{g})\end{array}$ & $\begin{array}{c}\text { Idade } \\
(\mathrm{Ma})\end{array}$ \\
\hline $\mathrm{N}-21$ & 7281 & 6,6044 & 2,04 & 342,72 & $1.000 \pm 22$ \\
$\mathrm{~N}-22 \mathrm{~A}$ & 7282 & 7,3328 & 1,47 & 256,02 & $730 \pm 25$ \\
\hline
\end{tabular}




\subsubsection{Veio quartzo-feldspático (com monazita) da Falha do Engenho (amostra N-73): Determinação U-Pb}

No dominio da Falha do Engenho, observou-se uma exposição onde rochas cisalhadas do Grupo Nova Lima são cortadas por veios quartzo-feldspáticos, não deformados, atingindo até $1 \mathrm{~m}$ de espessura. Os veios continham grandes cristais de monazita, de até $2 \mathrm{~cm}$. Uma análise U-Pb preliminar, realizada por Nuno Machado (com. escrita), datou a monazita em cerca de 596 Ma. Esta deve ser a idade de cristalização da monazita. Os veios não estão deformados e não há qualquer registro isotópico, na região em causa, de que condições metamórficas capazes de promover resetting (ou cristalização) da monazita tenham sido alcançadas ao final do Proterozóico. De fato, tais processos são conhecidos apenas em condições metamórficas das fácies anfibolito a granulito (e.g. Heaman \& Parrish 1991). Por outro lado, a formação de onazita em processos hidrotermais de baixa temperatura já foi descrita anteriormente (Aleinikoff \& Grauch 1990), devendo-se aplicar ao caso estudado.

A melhor interpretação para a gênese dos veios é que estejam relacionados a processos de circulação de fluidos na zona de falha, durante o último evento de reativação da Falha do Engenho. A idade da monazita indica que tal reativação ocorreu durante o Evento Brasiliano.

\subsubsection{Considerações sobre a evolução geológica da região meridional do Quadrilátero Ferrífero}

A idade do Granito Salto do Paraopeba, 2.612 $\pm 5 \mathrm{Ma}$, é cerca de $100 \mathrm{Ma}$ mais jovem que a última granitogênese arqueana até então datada na região do Quadrilátero Ferrífero (Machado et al. 1992, Machado \& Carneiro 1992). Este corpo, muito provavelmente, deve marcar o evento magmático mais tardio ligado a um processo de cratonização do final do Arqueano.

A intrusão dos pegmatitos de Salto do Paraopeba, no quartzito da Formação Moeda, deve ter ocorrido durante o Evento Transamazônico, considerando a idade $\mathrm{Pb}-\mathrm{Pb}$ obtida. Como os grãos de zircão, analisados por U-Pb, eram arqueanos, o mais provável é que tenham sido herdados de porções assimiladas do próprio quartzito encaixante. Uma hipótese acerca da gênese dos pegmatitos é que se relacionem ao Batólito Alto Maranhão. O caráter tonalítico deste poderia explicar a composição dos pegmatitos, que contém anfibólio.

A idade transamazônica do Batólito Alto Maranhão soma-se às idades semelhantes obtidas para outros granitóides, como os de Porto Mendes (Teixeira 1985), Lavras (Heilbron et al 1989), 
Tabuões (Quéméneur \& Vidal 1989) e Quilombo (Choudhuri et al. 1992). No conjunto, esses corpos definem um arco magmático que se estende ao longo de toda a borda meridional do Cráton do São Francisco e também no domínio da faixa marginal (Faixa Alto Rio Grande). A disposição dos granitóides transamazônicos encontra-se apresentada na figura 32 .

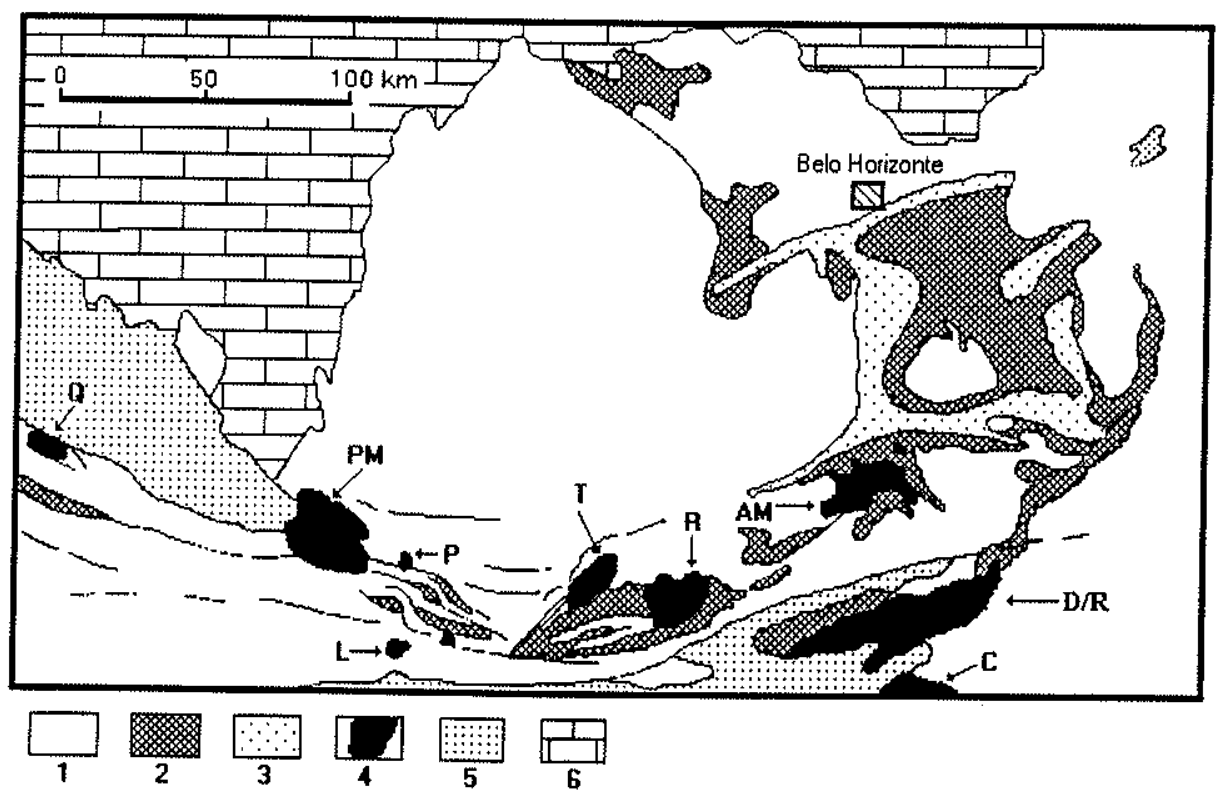

Figura 32: O arco magmático transamazônico na porção meridional do embasamento do Cráton do São Francisco (modificado de Quéméneur \& Garcia 1993).

Legenda: 1 - Complexos gnáissicos arqueanos; 2 - Greenstone belts arqueanos; 3 - Supergrupo Minas; 4 - Granitóides transamazônicos (AM - Alto Maranhão; D/R - Dores do Campo/Ressaquinha; $C$ Campolide; $R$-Ritápolis; $T$ - Tabuões; P - Perdões; $L$ - Lavras; PM-Porto Mendes; $Q$ - Quilombo); 5 - Grupos Araxá e São João del Rei;6- Grupo Bambuí.

Os dados geoquímicos e a idade-modelo Sm-Nd (TDM) do Batólito Alto Maranhão indicam origem mantélica, provavelmente em ambiente de margem continental ativa. $O$ caráter pré-

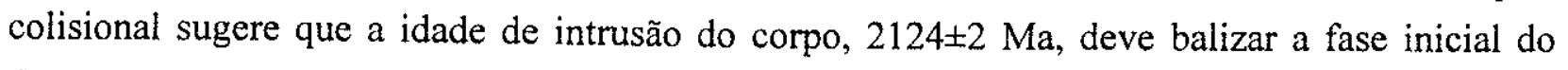
Evento Transamazônico. Um quadro hipotético da situação geológica para a região meridional do Quadrilátero Ferrífero, durante essa fase, é mostrado na figura 33a. Na figura, a Falha do Engenho é colocada como limite da Bacia Minas apenas como recurso gráfico. Weiss (1989) demonstrou que o Supergrupo Minas recobriu porções ao sul da falha, ainda que esta tenha tido papel ativo durante a sedimentação. É provável que a bacia continuasse para sudoeste através de 


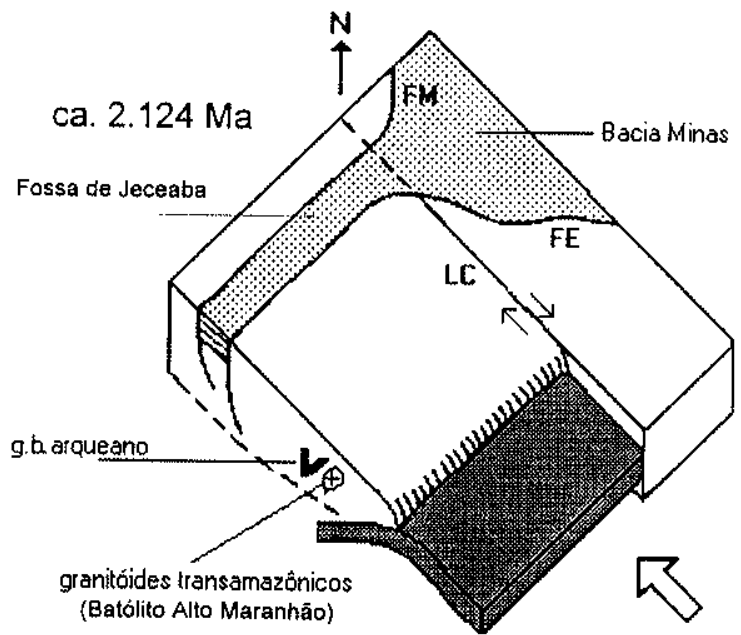

(a)

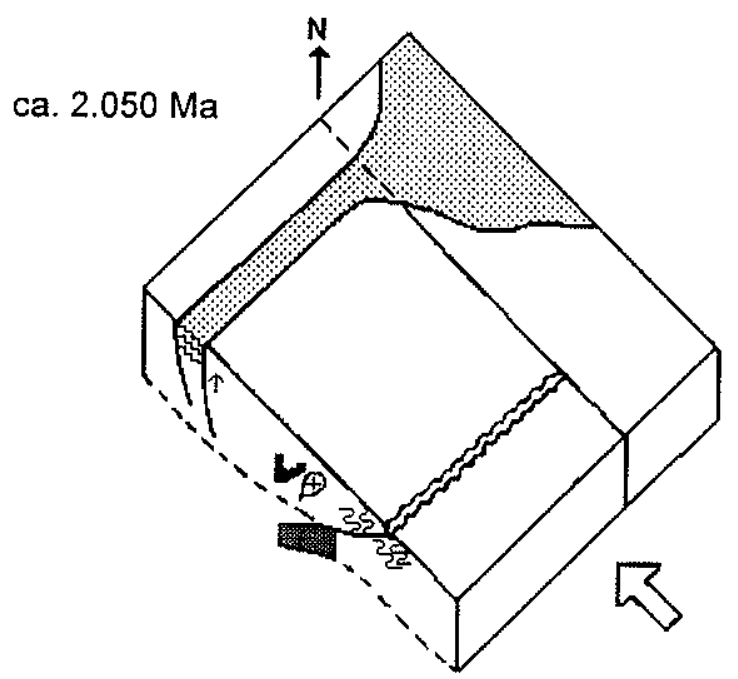

(b)

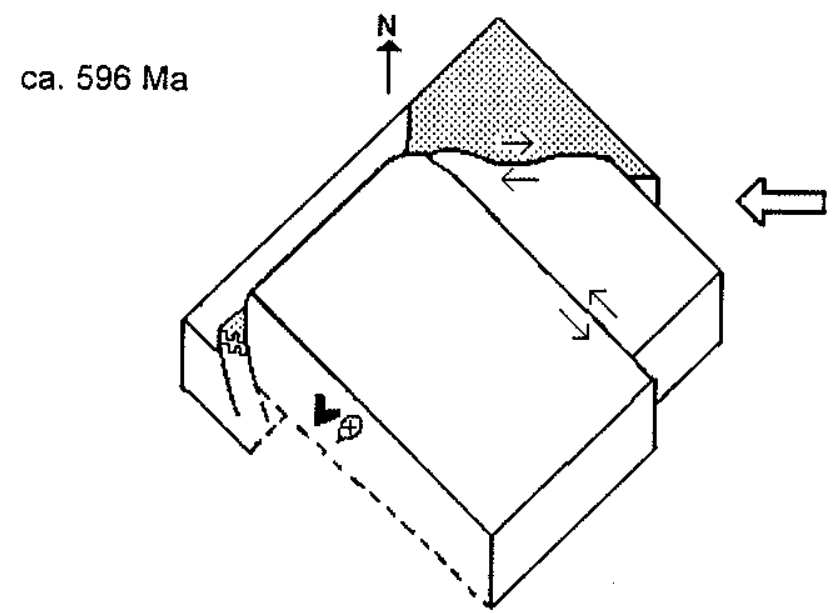

(c)

Figura 33: Modelo evolutivo para a região a sul do Quadrilátero Ferriffero. Vide explicações no texto.

Legenda: $F E=F$ alha do Engenho; $F M=F$ alha de Moeda; $L C=$ Lineamento Congonhas 
uma fossa linear (Fossa de Jeceaba), sugerido pela estreita faixa de ocorrência de rochas do Supergrupo Minas entre o Quadrilátero Ferrifero e a Serra de Bonsucesso.

O sentido da subducção, de SE para NW, é sugerido pela forma do arco magmático e pelo acervo estrutural do Batólito Alto Maranhão e supracrustais do Grupo Nova Lima. Acredita-se que o Lineamento Congonhas tenha exercido um papel importante durante a fase pré-colisional. Segundo Nummer et al. (1992), a primeira etapa de evolução do lineamento foi sincrônica com a intrusão do Batólito Alto Maranhão e de caráter transcorrente. Portanto, o Lineamento Congonhas pode ter funcionado como uma zona de transferência, resultante da indentação da margem continental. Tal indentação explicaria o deslocamento do arco magmático em relação à região do Quadrilátero Ferrífero, que não é afetada diretamente por este.

A idade do evento colisional Transamazônico (Figura 33b), entre 2.065 e $2.035 \mathrm{Ma}$, é sugerida pelas idades $\mathrm{U}-\mathrm{Pb}$ de titanitas no Quadrilátero Ferrifero, que definem o ápice metamórfico. Granitos sin-colisionais são registrados no arco magmático (Teixeira \& Figueiredo 1991, Pires e Barbosa 1993), mas carecem de datações precisas.

A conjugação de movimentos frontais e laterais, durante a colisão, teria resultado na estrutura regional arqueada do Distrito Manganesífero de Lafaiete. Possivelmente, também como reflexo da colisão, verificou-se uma primeira fase de inversão da Fossa de Jeceaba.

Durante o Evento Brasiliano (Figura 33c), o campo de tensões foi E-W, conforme demonstrado por diversos trabalhos no Quadrilátero Ferrífero (e.g. Chemale Jr. et al. 1991). A reativação da Falha do Engenho e Lineamento Congonhas teria originado um movimento em par conjugado. Esta afirmativa é coerente com a descrição das etapas finais de movimentação ao longo desses falhamentos (Nummer et al 1992, Romano et al. 1992).

A movimentação lateral do bloco a sul da Falha do Engenho seria acomodada por movimentos frontais, a partir do ponto de inflexão da falha, provocando o generalizado soerguimento do bloco. Tal soerguimento, já sugerido por Guild (1957), levaria à erosão de todas as sequências supracrustais transamazônicas porventura existentes nesse bloco, expondo a raiz do arco magmático e seu embasamento arqueano. Isto explicaria o fato da Falha do Engenho, atualmente, justapor blocos crustais de profundidades diferentes.

O Evento Brasiliano provocou o resetting localizado do sistema $\mathrm{Rb}$-Sr (no Batólito Alto Maranhão) e rejuvenescimentos parciais das idades K-Ar. A natureza de tais registros é coerente com a hipótese de que o Evento Brasiliano tenha se manifestado, principalmente, pela movimentação de blocos crustais ao longo de falhamentos pré-existentes, sem promover um retrabalhamento tectono-metamórfico mais generalizado das unidades geológicas presentes na área. 


\section{EVENTOS DE SEDIMENTAÇÃO: CRONOLOGIA COM BASE NA DATAÇÃO DE ZIRCÕES DETRÍTICOS}

\subsection{DATAÇÃO DE ZIRCÕES DETRÍTICOS: DADOS OBTIDOS E DISCUSSÃO}

A datação de populações de zircões detríticos, além de fornecer informações sobre as áreas-fonte de sedimentos, auxilia na determinação de limites temporais de deposição e no estabelecimento de relações cronológicas entre unidades sedimentares (e.g. Gariépy et al. 1984, Robb et al. 1990, Davis et al. 1990, Sager-Kinsman \& Parrish 1993).

Cinco amostras foram analisadas para o presente estudo (Figura 34). Duas delas eram quartzitos da formação basal do Supergrupo Minas, Formação Moeda, provenientes da aba ocidental do Sinclinal Moeda. As amostras foram coletadas na base da unidade (amostras QF-1 e M-88-10). As demais amostras consistiam de: metagrauvaca do Grupo Sabará, coletada na parte ocidental da Serra do Curral (amostra SAB); quartzito do Grupo Itacolomi na região de Ouro Preto (amostra ITAC) e quartzito do Supergrupo Espinhaço da Serra das Cambotas (amostra N16).

Desse conjunto de amostras foram obtidas 110 datações de zircões detríticos pelo método LP-ICPMS. As análises foram realizadas na Université de Montréal por Rui Feng e Nuno Machado e uma avaliação preliminar dos resultados foi apresentada por Machado et al. (1993). Deve-se ressaltar que as idades fornecidas pelo método LP-ICPMS são idades mínimas $\left({ }^{207} \mathrm{~Pb} / 206 \mathrm{~Pb}\right)$. Feng et al. (1993) utilizaram este método na datação de zircões cuja idade U-Pb já havia sido estabelecida pelo método convencional. No caso de zircões de boa qualidade e com história simples de perda de $\mathrm{Pb}$, as idades ${ }^{207} \mathrm{~Pb} / 206 \mathrm{~Pb}$ aproximavam-se muito das idades U-Pb. Entretanto, para um grupo de zircões afetados por episódios múltiplos de perda de $\mathrm{Pb}$, as idades ${ }^{207} \mathrm{~Pb} / 206 \mathrm{~Pb}$ eram idades mistas. Outra limitação da metodologia é que apenas os zircões grandes e limpos, sem fraturas, se prestam para análise, o que diminui a representatividade da amostragem.

As idades dos zircões das duas amostras da Formação Moeda variam entre $2.990 \pm 37$ Ma e

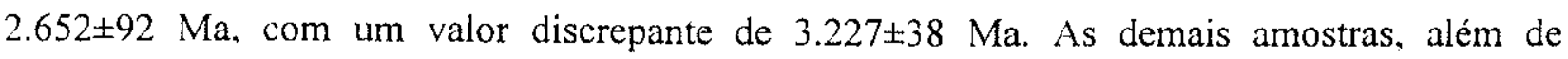
conterem zircões arqueanos na mesma faixa de idade daqueles da Formação Moeda, exibem zircões com idades do Paleoproterozóico, o mais novo com 2.122士140 Ma. 


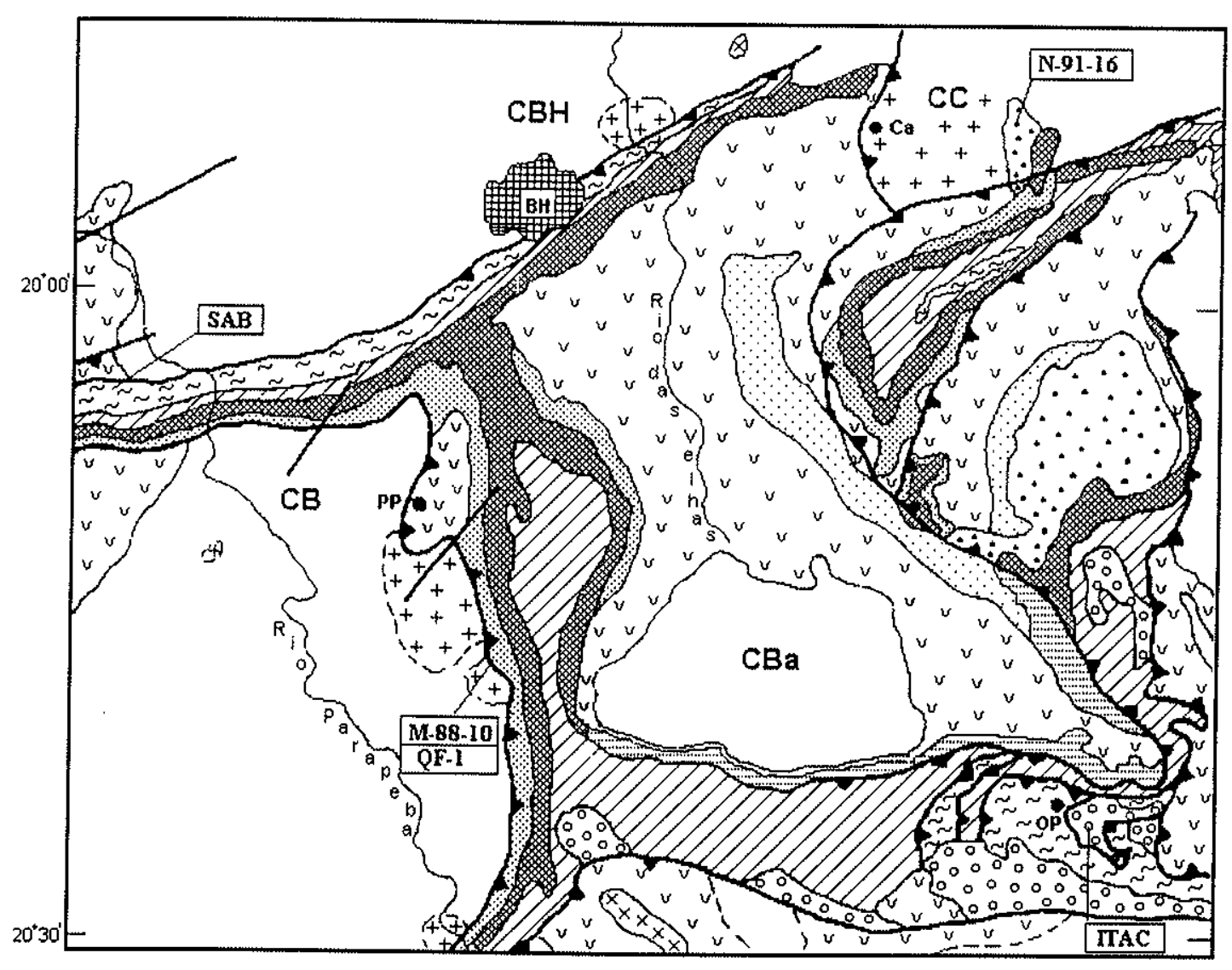

Figura 34: Localização das amostras com datação de zircões detríticos. Legenda: ver figura 3

A despeito da necessária cautela na interpretação das idades obtidas, elas são coerentes com o conhecimento geocronológico atual da área investigada. Adicionalmente, a boa distribuição das idades sugere que a amostragem foi representativa da população de zircão. Cerca de $70 \%$ das idades de zircão situam-se no intervalo 2.950-2.650 Ma (Figuras 35 e 36), que inclui os principais eventos tectono-magmáticos registrados nos complexos arqueanos que circundam o Quadrilátero Ferrifero. Portanto, tais complexos devem representar a área-fonte principal das unidades detríticas estudadas. Considerando o caso específico da amostra do Grupo Sabará, ao se incluir os erros, constata-se que $43 \%$ das idades mostram superposição no intervalo $2.860+14 /$ $10 \mathrm{Ma}$. Esta é a idade do principal evento registrado no Complexo Belo Horizonte, adjacente à área amostrada. Portanto, acredita-se que parte importante das idades ${ }^{207} \mathrm{~Pb} / 206 \mathrm{~Pb}$ se aproximem das idades $\mathrm{U}-\mathrm{Pb}$ dos eventos geradores ou de resetting dos zircões. 
As idades de zircões da Formação Moeda indicam área(s)-fonte(s) exclusivamente arqueanas (Figura 35a). A idade do zircão detrítico mais novo, $2.652 \pm 92 \mathrm{Ma}$, define um limite máximo para o início da deposição da unidade. As duas amostras da Formação Moeda, apesar de provenientes do mesmo local e separadas por pequeno intervalo estratigráfico, exibem faixas de idade distintas e sem superposição (amostra QF-1: $2.990 \pm 37$ - $2.780 \pm 59$ Ma; amostra M-88-11: $2.782 \pm 34-2.652 \pm 92 \mathrm{Ma}$ ). É muito provável que essa diferença reflita uma mudança de áreafonte, por exemplo, devido a um remodelamento da paleodrenagem. A área-fonte da amostra QF-1 poderia estar situada a norte, no Complexo Belo Horizonte. Isto é coerente com os estudos de paleocorrentes na Formação Moeda, na área estudada, que determinaram um vetor de transporte principal para sul (Vilaça 1981, Renger et al. 1993). Reforça essa hipótese o fato de $73 \%$ das idades de zircão superporem-se no intervalo $2.860+14 /-10 \mathrm{Ma}$, idade do evento principal no Complexo Belo Horizonte. A área-fonte para a amostra M-88-11 poderia estar situada a oeste, no Complexo Bonfim, cujos principais eventos tectono-magmáticos foram datados em 2.780-2.770 ..720-2.700 Ma (Machado et al. 1992, Machado \& Carneiro 1992).

As amostras do Supergrupo Espinhaço, Grupo Itacolomi e Grupo Sabará continham zircões detríticos gerados e/ou rejuvenescidos isotopicamente durante eventos ígneo-metamórficos do Paleoproterozóico (Figuras 35b, 35c e 35d). Tal fato reflete uma idade de deposição bem mais nova que aquela do início da deposição do Supergrupo Minas. A idade do zircão mais novo do Grupo Sabará é $2.122 \pm 140 \mathrm{Ma}$, coerente com uma datação U-Pb de $2.125 \pm 4 \mathrm{Ma}$ para outro zircão da mesma rocha (Machado et al. 1992). Esta idade é interpretada como o limite máximo "nra a deposição do Grupo Sabará. O Grupo Itacolomi é mais novo, por ser estratigraficamente . )erior ao Grupo Sabará. A deposição do Supergrupo Espinhaço iniciou-se por volta de 1.750$1.700 \mathrm{Ma}$ (Brito Neves et al. 1979, Machado et al. 1989b). Apesar das diferenças na idade de deposição, o padrão geocronológico fornecido pelos zircões das três unidades é muito semelhante. Isto sugere que a área continental exposta, quando da deposição de cada uma das unidades, pode ter sido essencialmente a mesma.

As idades paleoproterozóicas dos zircões podem ser explicadas de duas maneiras. Uma hipótese é que se trate de zircões arqueanos afetados pelo metamorfismo transamazônico, $c a$. $2.050 \mathrm{Ma}$, de que resultou perda parcial de $\mathrm{Pb}$. Alternativamente, alguns destes zircões podem ter sido gerados em eventos do Paleoproterozóico. Considerando o conjunto das análises (Figura 36 ), constata-se uma diminuição do número de zircões no intervalo entre $2.650-2.450 \mathrm{Ma}$, seguido de uma concentração importante a $2.350 \pm 100$ Ma. Existe a possibilidade de esta ser a idade de uma fonte dos sedimentos, ainda não detectada. 


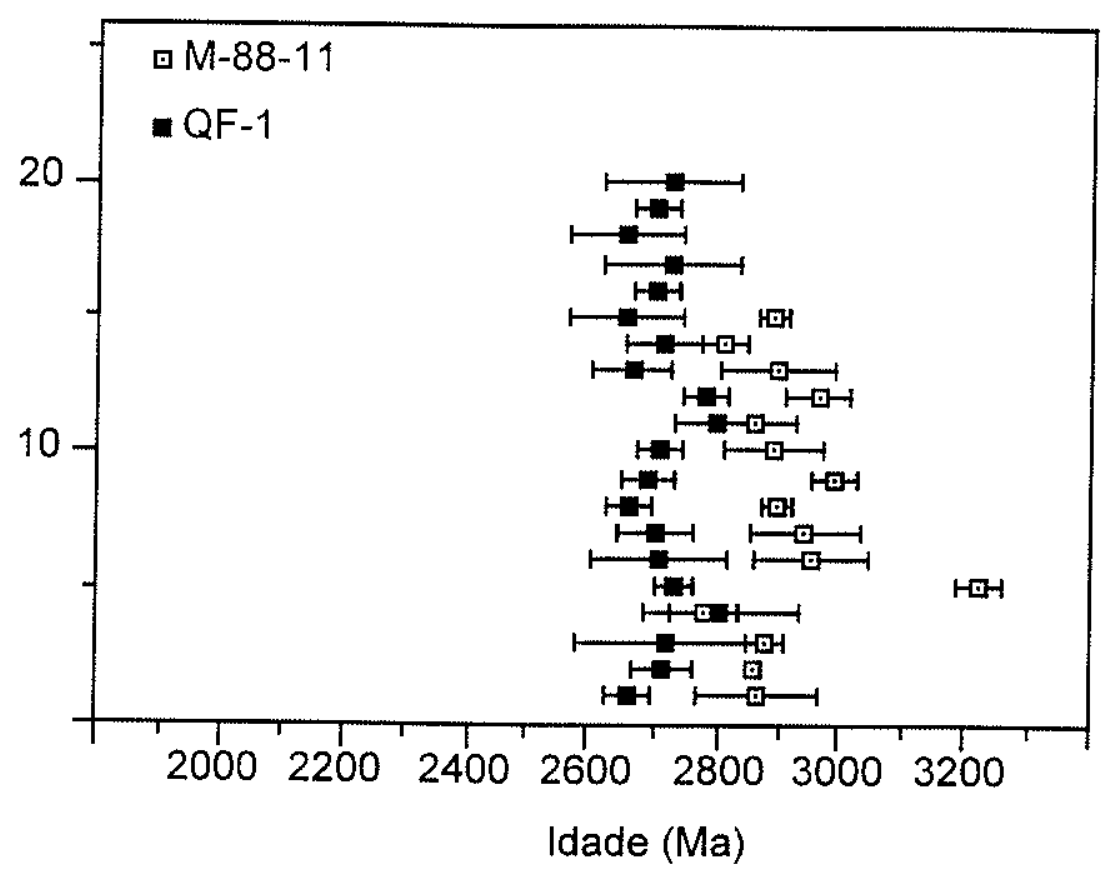

(a)

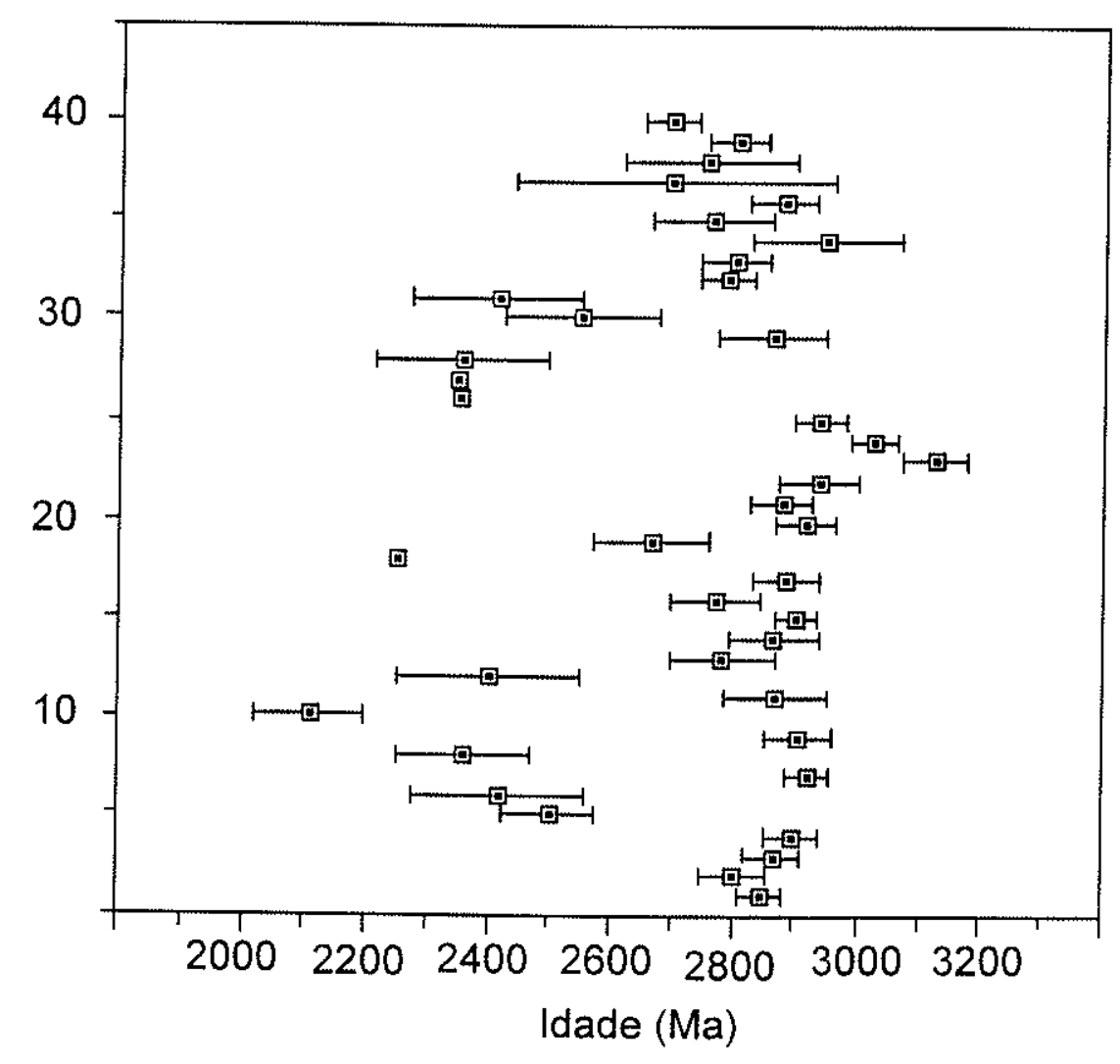

(b)

Figura 35: (continua na página seguinte) 


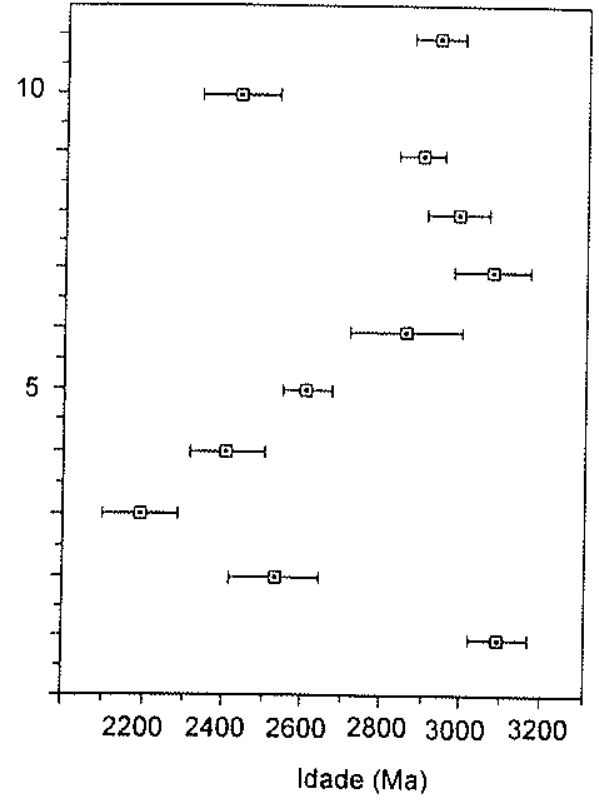

(c)

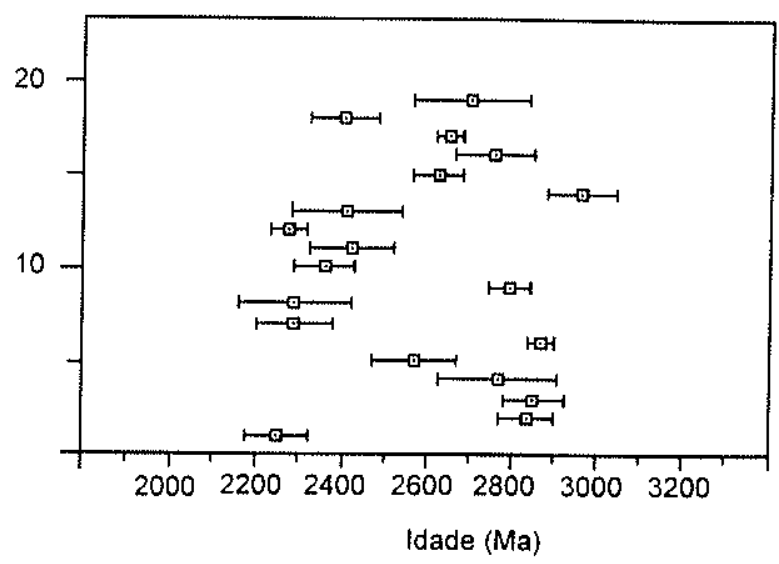

(d)

Figura 35: Distribuição das idades ${ }^{207} \mathrm{~Pb} / 206 \mathrm{~Pb}$ de zircões detríticos (os erros estão representados). (a) Formação Moeda, amostras QF-1 e M-88-11; (b) Grupo Sabará, amostra $S A B$; (c) Grupo Itacolomi, amostra ITAC; (d) Supergrupo Espinhaço, amostra N-16 (os grãos estão numerados no eixo $y$, na ordem em que foram feitas as análises).

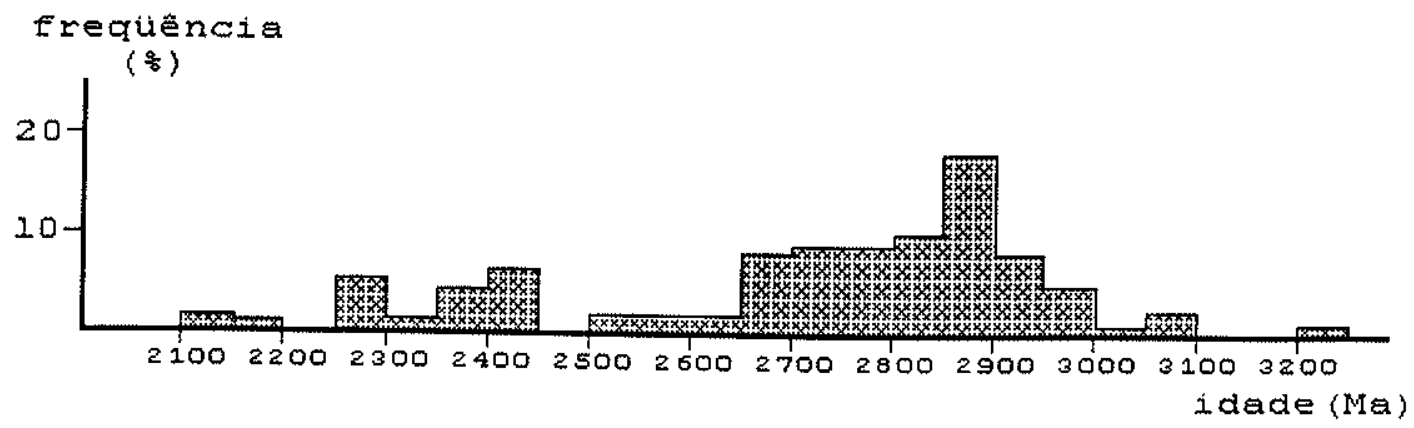

Figura 36: Histograma de distribuição das idades de zircões detríticos. 


\subsection{CRONOLOGIA DA SEDIMENTAÇÃO}

\subsubsection{Supergrupo Minas}

A coluna padrão para o Supergrupo Minas, extraída de Dorr (1969), é apresentada na figura 37, com uma modificação. Esta segue proposição de Barbosa (1968), retirando a Formação Sabará do Grupo Piracicaba e elevando-a à categoria de grupo. Constata-se a existência de discordâncias entre os Grupos Itabira e Piracicaba e entre este último e o Grupo Sabará. O possível significado tectônico e posicionamento temporal das superfícies de discordância, juntamente com uma proposta de cronologia da sedimentação do Supergrupo Minas, serão discutidos nos próximos ítens. Uma síntese desta proposta encontra-se na figura 38.

\subsubsection{Grupos Caraça e Itabira}

Aplicando-se a classificação de Condie (1982) para as seqüências supracrustais do Paleo e Mesoproterozóico, o Supergrupo Minas (excluído o Grupo Sabará) constitui uma associação-I (quartzite-carbonate-shale) com presença de espessa formação ferrífera bandada. O ambiente de deposição para estas associações são as bacias intracratônicas ou de margem continental passiva. $O$ desenvolvimento inicial da bacia Minas deve ter sido precedido pela estabilização de uma plataforma, ao final do Arqueano. Os estágios finais desse processo de cratonização, caracteristicamente, são marcados pela intrusão de granitos de alto $\mathrm{K}$, constituindo plutonitos isolados de dimensões relativamente pequenas.

Na região do Quadrilátero Ferrifero, as intrusões graníticas arqueanas mais tardias, datadas até o presente, são o Granito Salto do Paraopeba (2.612 $\pm 5 \mathrm{Ma})$ e o Granodiorito de Florestal

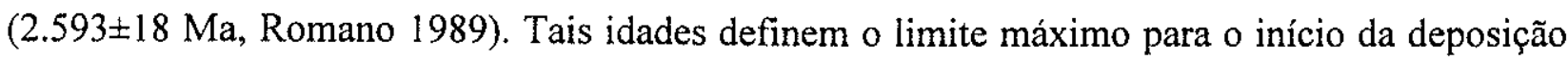

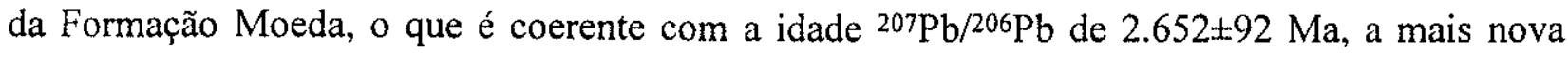
dentre os zircões detríticos analisados em amostras desta unidade. Renger et al. (1994) estimaram o início da deposição da Formação Moeda em 2.590-2.560 Ma.

Uma idade para a deposição de dolomitos do topo da Formação Gandarela, 2.420 19 Ma, foi obtida por Babinski et al. (1991). Babinski et al. (1993) estimaram o início da deposição das formações ferríferas da Formação Cauê em $2.520 \mathrm{Ma}$. Em conclusão, existe um conjunto de evidências que permite posicionar a deposição dos grupos Caraça e Itabira entre $2.575 \pm 15$ e $2.420 \pm 19 \mathrm{Ma}$. 


\begin{tabular}{|c|c|c|c|}
\hline Supergrupo & Grupo & Formação & Litologia \\
\hline \multirow{11}{*}{ MINAS } & Sabará & & $\begin{array}{l}\text { clorita-xisto e fillito. metatufo. grauvaca, tilóide. } \\
\text { conglomerado, quartzito e alguma formação ferrifera }\end{array}$ \\
\hline & \multicolumn{3}{|c|}{ Discordância erosiva local } \\
\hline & \multirow{4}{*}{ Piracicaba } & Barreiro & filito e fillito grafitoso \\
\hline & & Taboões & ortoquartzito \\
\hline & & Fecho do Funil & filito quartzoso. filito dolomitico, dolomito silicoso \\
\hline & & Cercadinho & $\begin{array}{l}\text { quartzito ferruginoso, quartzito, grit, filito, tillito } \\
\text { ferruginoso. subordinadamente conglomerado e } \\
\text { dolomito }\end{array}$ \\
\hline & \multicolumn{3}{|c|}{ Discordância erosiva local } \\
\hline & \multirow[b]{2}{*}{ Itabira } & Gandarela & $\begin{array}{l}\text { dolomito, algum calcário, itabirito dolomítico, itabirito, } \\
\text { filito dolomitico }\end{array}$ \\
\hline & & Cauê & $\begin{array}{l}\text { itabirito (formação ferrifera de fácies óxido), itabirito } \\
\text { dolomítico; tilito e dolomito subordinados }\end{array}$ \\
\hline & \multirow[t]{2}{*}{ Caraça } & Batatal & $\begin{array}{l}\text { filito, filito algo grafitoso, subordinadamente metachert } \\
\text { e formação ferrifera de fácies óxido }\end{array}$ \\
\hline & & Moeda & $\begin{array}{l}\text { Fácies parálica: ortoquartzito, grit, conglomerado, filito. } \\
\text { Fácies tabular: quartzito sericítico, filito quartzoso. } \\
\text { protoquartzito. }\end{array}$ \\
\hline
\end{tabular}

Figura 37: Coluna litoestratigráfica do Supergrupo Minas (segundo Dorr 1969, modificado segundo proposta de Barbosa 1968)

Segundo Renger et al. (1993), a Formação Moeda é constituída por duas unidades de caráter fluvial, com quartzitos e conglomerados, exibindo uma unidade intermediária composta por quartzitos finos e filitos, representando uma transgressão marinha. As profundas variações de espessura e mudanças de fácies refletiriam a natureza segmentada da bacia, com a presença de vários altos do embasamento. Este aspecto, associado à recorrência da sedimentação conglomerática em níveis diferentes da formação, são indicativos de pertubações tectônicas sindeposicionais (Renger et al. 1994). Tal tectonismo, de caráter extensional, marcaria a implantação inicial da Bacia Minas em estruturas do tipo graben, como proposto por Belo de Oliveira \& Teixeira (1990). 
A sedimentação da Formação Batatal define a passagem para um ambiente marinhoplataformal (Moraes 1985). O aporte de material terrígeno diminui progressivamente, refletindo a peneplanização das áreas de abastecimento (Barbosa 1968), implantando-se a sedimentação química e carbonática das formações Cauê e Gandarela. Segundo Barbosa (1968), a deposição do Grupo Itabira associa-se a um período de grande estabilidade tectônica da bacia.

\subsubsection{Grupo Piracicaba}

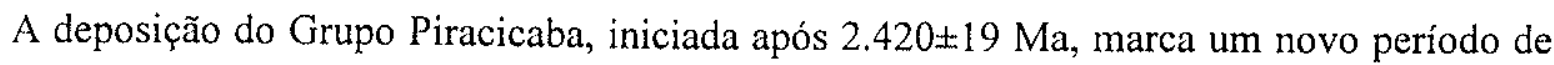
instabilidade tectônica da bacia. Partes da bacia sofreram soerguimento, originando a discordância entre os grupos Piracicaba e Itabira. A Formação Cercadinho apresenta conglomerado basal, exibindo clastos provenientes da erosão do Grupo Itabira (Dorr 1969). Um evento de movimentação de blocos, por volta de $2.400 \mathrm{Ma}$, já havia sido sugerido por Teixeira (1985) para explicar processos de rejuvenescimento isotópico do sistema $\mathrm{Rb}$-Sr nesta idade. Outro possível reflexo isotópico deste evento seria dado por um episódio de remobilização de galenas, em minas do Distrito de Nova Lima, datado em 2.425-2.410 Ma (Thorpe et al. 1984).

Moraes (1985) classifica a Formação Cercadinho como um complexo de leques deltaicos com turbiditos associados, caracterizando uma seqüência regressiva. Esta é sucedida pela sequiencia transgressiva representada pela Formação Fecho do Funil (Moraes 1985), possivelmente refletindo a subsidência gradual da bacia (Barbosa 1968). A Formação Fecho do Funil apresenta truncamentos sedimentares (Barbosa 1968), que poderiam evidenciar a presença de falhamentos ativos.

O período de instabilidade tectônica contemporâneo à deposição das formações Cercadinho e Fecho do Funil foi acompanhado de manifestações vulcânicas, como o demonstra a presença de metatufos intercalados nestas unidades, descritos por Guild (1957). Na hipótese de que o vulcanismo tenha sido bem mais volumoso que os raros remanescentes conhecidos deixam antever, ter-se-ia uma possível fonte para a população de zircões detríticos na faixa de $2.350 \pm 100$ Ma, encontrados em unidades mais novas que o Grupo Piracicaba. O ciclo sedimentar do Grupo Piracicaba culmina com a deposição, em águas profundas, das formações Taboões e Barreiro.

O limite temporal para o topo do Grupo Piracicaba não está bem definido. O registro sedimentar da unidade parece indicar a estabilização progressiva da bacia. Portanto, o término da deposição deve anteceder o início do Evento Transamazônico, o que sugere que o topo do Grupo Piracicaba seja de idade mais antiga que 2.124 2 Ma. Esta é a idade do Batólito Alto Maranhão, considerado um granitóide pré-colisional do Evento Transamazônico. 


\subsubsection{Grupo Sabará}

A principal faixa de ocorrência da unidade é aquela que bordeja o flanco setentrional da Serra do Curral. O Grupo Sabará ocorre ainda na região de Ouro Preto, no Sinclinal Gandarela e, provavelmente, no Sinclinal Dom Bosco e região de Congonhas (Dorr 1969).

Na faixa ao longo da Serra do Curral, o Grupo Sabará é composto, na base, por xistos (filitos) cloríticos com intercalações frequentes de metagrauvacas, mais raro quartzito e metachert. No topo, predominam largamente os xistos, podendo conter granada e estaurolita (Gair 1962). Nesta mesma faixa, Costa (1961) descreveu a presença de metatufos de composição entre andesítica e basáltica e Ferrari (1980) identificou metabasaltos muito alterados. Estudos petrográficos do autor identificaram as rochas filíticas como metapelitos, compostos essencialmente por quartzo, sericita e clorita. Crescimento de minerais como biotita, granada e estaurolita refletem o incremento do metamorfismo. A matriz das metagrauvacas possui a mesma composição dos filitos, exibindo cristais maiores de quartzo e feldspato, além de fragmentos líticos subordinados. Análises químicas de metapelitos e metagrauvacas da Formação da Sabará foram apresentadas por Jordt-Evangelista (1992).

O Grupo Sabará recobre todas as formações do Grupo Piracicaba caracterizando, em alguns locais, uma discordância erosiva basal (Dorr 1969). Conglomerados basais são descritos na Serra do Curral e na região de Ouro Preto, contendo clastos originados das formações sotopostas do Grupo Piracicaba (Barbosa 1968). Níveis conglomeráticos intercalados na seqüência estão também presentes, como o conglomerado exposto em um corte da rodovia Fernão Dias, parte ocidental da Serra do Curral, descrito por Simmons (1968). Os seixos são rolados, atingindo até $20 \mathrm{~cm}$ de diâmetro, compostos por quartzito, quartzo e granito. Na região de Ouro Preto, seixos e blocos (predominantemente de quartzito e granito) ocorrem de forma esparsa nos xistos Sabará ao longo de toda a seção desta unidade (Barbosa 1968). Estas são as primeiras ocorrências conhecidas de clastos de composição granítica dentro do Supergrupo Minas.

Descrevendo o Grupo Sabará, Dorr (1969) afirma que: "...volcanism ... contributed sediments to the region, many of the rocks are turbidites, and the presence of granitic boulders indicates nearby crustal instability and the unroofing of batholithic masses...". Para Dorr (1969), assim como para Barbosa (1968), o Grupo Sabará representa uma sedimentação do tipo flysh. O termo flysh descreve uma pilha sedimentar que evolui em um contexto geodinâmico especifico. no caso os estágios pré a sin-colisionais do desenvolvimento de um cinturão orogênico (Homewood \& Lateltin 1988). Os limites temporais sugeridos para a Grupo Sabará parecem corroborar sua classificação como uma sequência tipo flysh, como se verá a seguir. 
Os zircões detríticos datados provinham de uma amostra de metagrauvaca, cujo estudo petrográfico revelou feições particulares. A matriz era composta por quartzo, sericita, clorita e carbonato, rica em pequenos cristais de granada. Exibia duas variedades de fragmentos líticos, constituídos por granitóides e vulcanitos. Os fragmentos de rocha vulcânica apresentavam matriz muito fina, com fenocristais euédricos de sanidina, subordinadamente plagioclásio, indicando composição intermediária a ácida. A população de zircão desta rocha era bastante variada. incluindo grãos rolados e foscos denunciando o transporte sedimentar, até cristais perfeitamente euédricos e com arestas bem definidas. Dois zircões deste último tipo foram analisados por Machado et al (1992), um deles fornecendo a idade U-Pb concordante de 2.125 4 Ma. Dentre os 45 outros zircões analisados por LP-ICPMS, a idade ${ }^{207} \mathrm{~Pb} / 206 \mathrm{~Pb}$ mais jovem obtida foi $2.122 \pm 140 \mathrm{Ma}$.

Existe uma notável coincidência entre as idades dos zircões mais novos da metagrauvaca e a idade de $2124 \pm 2$ Ma do Batólito Alto Maranhão. Não há dúvida de que a rocha grauvaqueana incorporou zircões gerados em algum tipo de manifestação magmática, plutônica ou extrusiva, contemporânea à fase pré-colisional do Evento Transamazônico. A própria amostra estudada evidenciava contribuição vulcânica. Evidentemente, não existem maneiras de demonstrar que tal vulcanismo foi sin-sedimentar, ou que o zircão com $2.125 \pm 4 \mathrm{Ma}$ provinha dos fragmentos vulcânicos. Fica, entretanto, a sugestão de que esta última idade seja a da própria sedimentação do Grupo Sabará.

A idade presumível e a natureza do pacote sedimentar do Grupo Sabará vêm ao encontro da hipótese de que a unidade representa a sedimentação sin-orogênica do Evento Transamazônico, o que delimitaria sua deposição entre, aproximadamente, 2.125 e 2.035 Ma.

\subsubsection{Grupo Itacolomi}

O número de zircões detríticos analisados para a amostra desta unidade é restrito, igual a 11, mas a distribuição das idades segue o mesmo padrão exibido pelos zircões do Grupo Sabará. A idade ${ }^{207} \mathrm{~Pb} / 206 \mathrm{~Pb}$ mais nova, $2.178 \pm 91 \mathrm{Ma}$, define o limite superior para a sedimentação do Grupo Itacolomi.

Barbosa (1968) comparou o Grupo Itacolomi a uma sequência tipo molassa. Sua descrição sugere que a deposição da unidade ocorreu em bacias restritas, cuja subsidência se iniciara quando da sedimentação do Grupo Sabará. É interessante confrontar este cenário com a afirmativa de Homewood \& Lateltin (1988) de que: "...flysh gives way to molasse both in space and in time". A sedimentação do tipo fluvial e lacustre do Grupo Itacolomi (e.g. Moraes 1985) é 
também um atributo comum da sedimentação molássica. Em conclusão, caso a sedimentação do Grupo Itacolomi tenha sido mesmo contínua à sedimentação do Grupo Sabará, sua idade máxima estaria balizada pelo evento colisional transamazônico, supostamente entre 2065-2035 Ma.

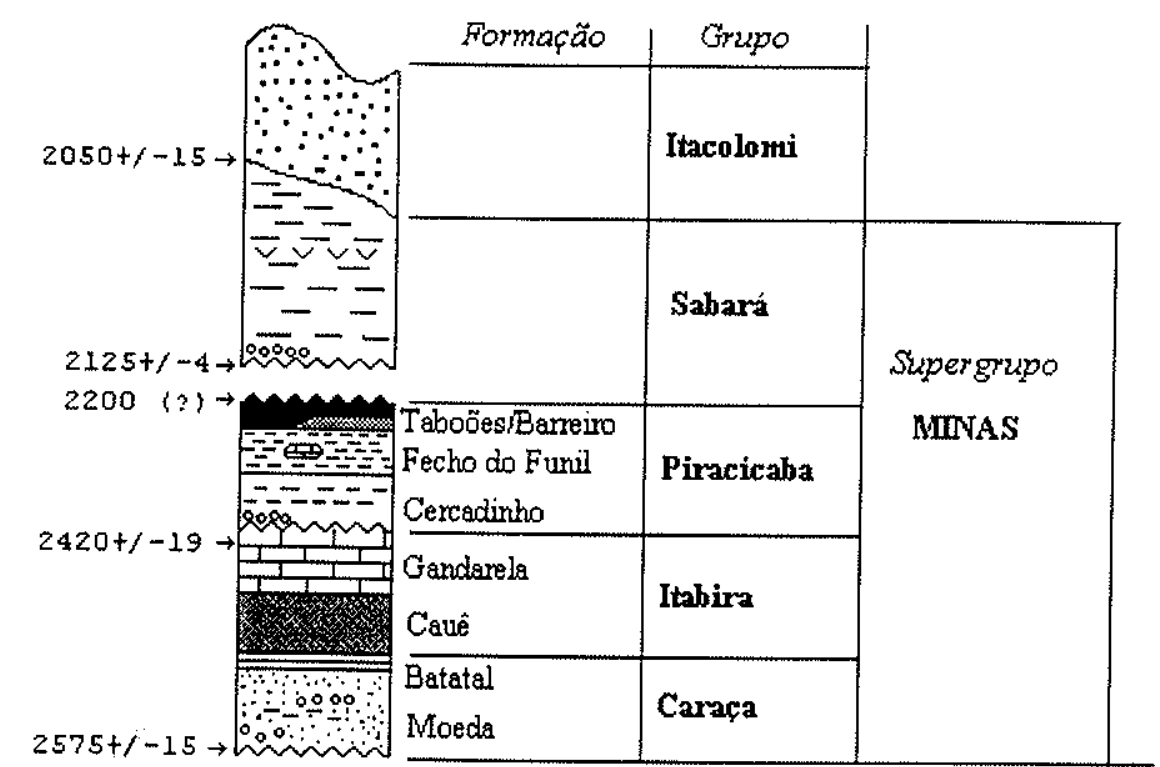

Figura 38: Coluna estratigráfica do Supergrupo Minas e Grupo Itacolomi, apresentando os limites temporais (em Ma) propostos para a sedimentação. 


\section{ALGUMAS CONSIDERAÇŌES SOBRE EVENTOS DE CISALHAMENTO E MINERALIZAÇÃO AURÍFERA COM BASE EM DETERMINAÇÕES U-Pb EM RUTILO E TITANITA}

\subsection{GEOLOLOGIA DA ÁREA INVESTIGADA (REGIÃo NORDESTE DO QUADRILÁTERO FERRÍFERO) E AMOSTRAGEM}

As grandes feições geológicos da região em causa são representadas pelo Complexo Gnáissico de Caeté, pelo Sinclinal Gandarela (constituído pelo Supergrupo Minas) e pela Serra das Cambotas, que representa a extensão meridional do Supergrupo Espinhaço. $O$ arcabouço estrutural é definido por um sistema de falhas de empurrão e falhas oblíquas, as quais constituem o Sistema Cambotas-Fundão, detalhadamente descrito por Chemale Jr. et al. (1991). Este sistema de falhamentos envolveu o Supergrupo Minas no Sinclinal Gandarela e porções do seu embasamento, representado na área pelo Grupo Nova Lima, posicionando o conjunto contra o próprio Grupo Nova Lima, a oeste, e o Complexo Caeté a norte. Esta situação pode ser visualizada no mapa da figura 39, extraído de Belo de Oliveira \& Vieira (1987). O mapa delimita um domínio alóctone e outro para-autóctone para o Grupo Nova Lima (Supergrupo Rio das Velhas). O primeiro corresponde à faixa desta unidade que foi envolvida pelo Sistema Cambotas-Fundão. Internamente a este domínio, Belo de Oliveira \& Vieira (1987) identificaram uma mega-estrutura antiformal, fortemente acilíndrica (estrutura Geriza), composta por metavulcânicas máficas e ultramáficas.

$\mathrm{Na}$ estrutura Geriza, especialmente em seus bordos falhados e cisalhados, encontram-se diversas ocorrências auríferas. A mineralização aurífera associa-se a processos de alteração hidrotermal nas zonas de cisalhamento (Belo de Oliveira et al. 1990). As metavulcânicas máficas, nas zonas de cisalhamento mineralizadas, evidenciam reações de sericitização, cloritização e carbonatação. No âmbito deste processo, ocorreu a formação de rutilo a partir da ilmenita pré-existente.

Uma fração de rutilo, extraída de amostra proveniente de uma zona mineralizada localizada no bordo sul da estrutura Geriza, foi fornecida por O. A. Belo de Oliveira (DOCEGEO). A localização da amostra (amostra CAE-1) encontra-se na figura 39. 
Outra amostra da região em foco, analisada por $\mathrm{U}-\mathrm{Pb}$, provém de uma pedreira próxima à localidade de Cocais (amostra M-88-8C, figura 39). Ocorre ai um gnaisse intensamente cisalhado e com bandas máficas, de onde se obteve uma fração de titanita.

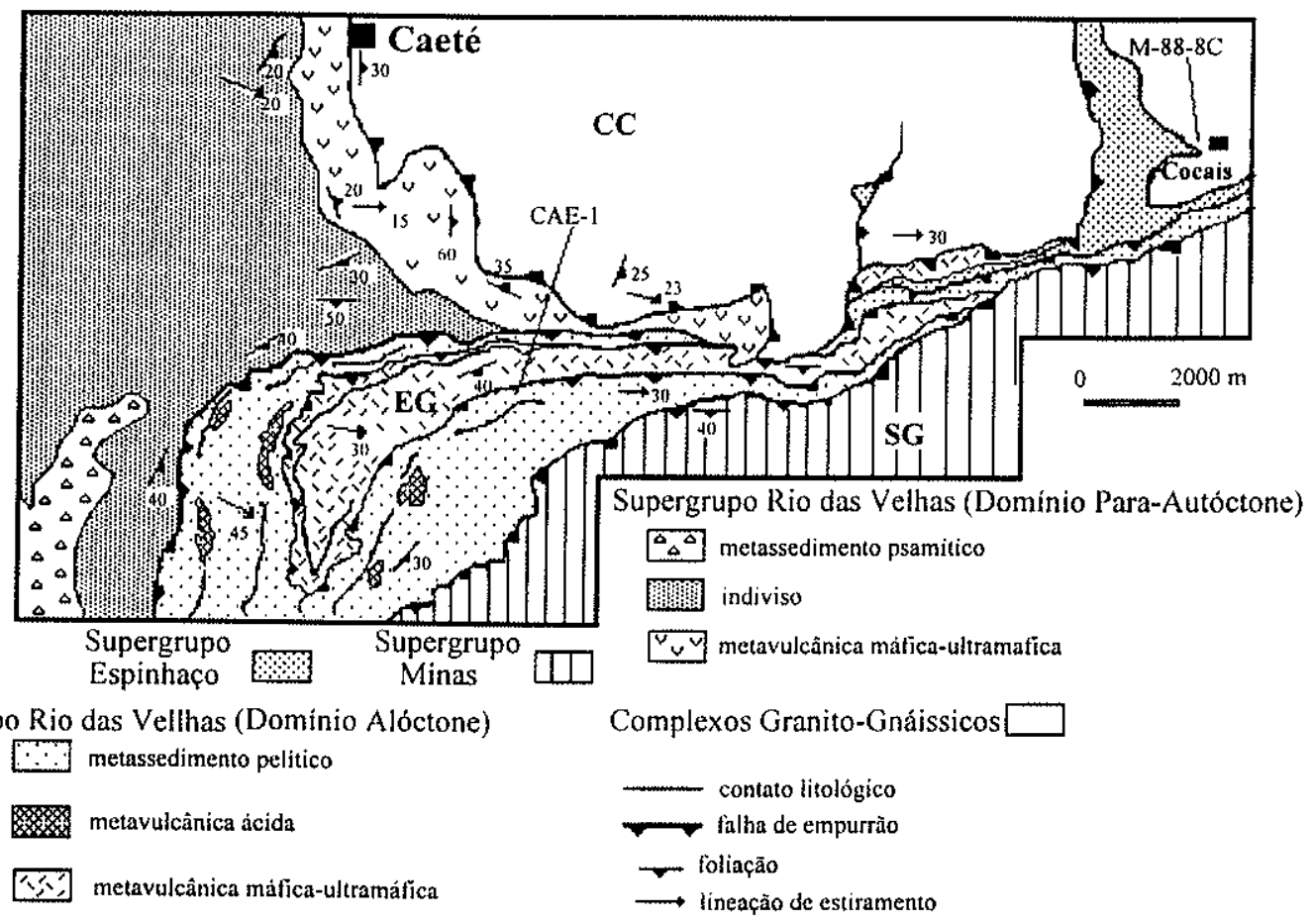

CC - Complexo Caeté: SG - Sinclinal Gandarela; EG - Estrutura Geriza

CAE-1 - localização de amostra

Figura 39: Mapa geológico da região de Caeté (segundo Belo de Oliveira \& Vieira 1987).

\subsection{GEOCRONOLOGIA}

\subsubsection{Determinações U-Pb em rutilo e resultados obtidos}

Embora possa ser encontrado em algumas rochas igneas, especialmente em rochas alcalinas e pegmatitos, o rutilo é muito mais comum nas rochas metamórficas. Rutilo metamórfico tem sido descrito em uma grande variedade de litotipos, abrangendo praticamente todos os graus metamórficos (Mezger et al. 1989). Quando comparado com outros minerais, 
como zircão, monazita e titanita, a utilização do rutilo em estudos geocronológicos U-Pb é relativamente rara na literatura geológica. O comportamento do sistema isotópico U-Pb neste mineral é bastante complexo, frequentemente resultando em idades muito discordantes e de difícil interpretação (e.g. Corfu \& Muir 1989).

Um aspecto comum ao estudo geocronológico de cinturões metamórficos de diversas idades é o fato de o rutilo, sistematicamente, fornecer idades mais novas que o zircão e mesmo que a titanita. Diferenças de até $200 \mathrm{Ma}$ já foram observadas. Mezger et al. (1989) apresentam um estudo dessa natureza para dois terrenos de alto grau do Arqueano e do Mesoproterozóico, onde concluem que as idades de rutilo são idades de resfriamento, sendo semelhantes às idades $\mathrm{K}$-Ar e Ar-Ar em hornblenda para as mesmas áreas. Com base nesta conclusão, calcularam a temperatura de fechamento do rutilo, em relação ao sistema $U-\mathrm{Pb}$, em $400 \pm 20^{\circ} \mathrm{C}$. Em outros trabalhos, Schärer et al. (1986) e Davis et al. (1989) também admitem que as idades mais novas do rutilo, em relação a outros minerais, possam representar idades de resfriamento, ou sua formação nos estágios finais do evento metamórfico principal. Entretanto, esses autores inclinam-se para a hipótese de que o rutilo tenha sido gerado em um evento metassomático posterior ao metamorfismo.

As situações onde o rutilo é, com certeza, um produto de reações hidrotermais, têm sido mais frequentemente tratadas na literatura, com o objetivo de datar tais processos e as mineralizações sulfetadas associadas (e.g. Richards et al. 1988, Wong et al. 1989, Corfu \& Muir 1989, Schandl et al 1990). Datações bastante precisas do evento hidrotermal gerador de rutilo têm sido obtidas, embora nem sempre este evento se relacione diretamente com a mineralização, que pode ser mais antiga (e.g. Corfu \& Muir 1989). Ficou também demonstrado que o rutilo hidrotermal pode formar-se a temperaturas consideravelmente mais baixas que a temperatura de bloqueio calculada por Mezger et al (1988). Neste caso, a idade obtida deve datar a cristalização do mineral (Schandl et al. 1990).

Os rutilos estudados no presente trabalho são de origem hidrotermal e, aparentemente, relacionados ao processo de mineralização aurífera. A fração analisada era composta por cristais bem formados, de hábito prismático e cor marron escura. Por serem os grãos muito opacos, não foi possível identificar a presença de inclusões. A fração foi submetida à abrasão por $1 \mathrm{~h}$ a uma pressão de 2psi. Os resultados analíticos são apresentados na tabela 20 e figura 40 . A análise é muito discordante $(24 \%)$ e com idade mínima $\left({ }^{207} \mathrm{~Pb} / 206 \mathrm{~Pb}\right)$ de $2.580 \mathrm{Ma}$. O conteúdo em $U$ era extremamente baixo, $3,2 \mathrm{ppm}$, sendo a razão ${ }^{206} \mathrm{~Pb} / 204 \mathrm{~Pb}$ igualmente muito baixa, igual a 70 . Isto aumenta a incerteza da idade, tornando necessário fazer a correção para o $\mathrm{Pb}$ comum. Esta foi feita assumindo uma composição isotópica inicial a partir da curva de crescimento do $\mathrm{Pb}$ de Stacey \& Kramers (1975) para $\mathrm{T}=2.776 \mathrm{Ma}$. Esta idade foi tomada do principal evento arqueano datado na região (Machado et al. 1982). Ainda que arbitrária, tal correção não tem qualquer 
influência na informação básica fornecida pela análise, a de que o rutilo deve ter cristalizado durante o Arqueano.

Existe outra análise de rutilo para uma área próxima, no Complexo Caeté (Machado et al. 1992). O rutilo provém de uma rocha gnássica milonitizada, cuja idade de cristalização, obtida a partir de análise de zircão, é 2.776+7/-6 Ma. O rutilo era também pobre em $U$ (6ppm) fornecendo idade mínima de $2.309 \mathrm{Ma}$, muito discordante. Belo de Oliveira \& Teixeira (1990) obtiveram, para outra faixa de gnaisses milonitizados do Complexo Caeté, idade $\mathrm{Rb}-\mathrm{Sr}$ de $2.130 \pm 101 \mathrm{Ma}$, interpretada como a idade do metassomatismo associado à milonitização. Esta idade é coerente com os dados $\mathrm{U}-\mathrm{Pb}$ para o metamorfismo transamazônico no Quadrilátero Ferrífero. Tal evento teria causado perda parcial de $\mathrm{Pb}$ no rutilo do gnaisse, mas sua cristalização tem que estar ligada a um evento mais antigo.

Conclusão semelhante pode ser admitida para o rutilo da zona mineralizada da estrutura Geriza. A discordância da análise indica um padrão complexo de perda de $\mathrm{Pb}$, devido à influência dos eventos proterozóicos. Entretanto, sua formação estaria relacionada a um episódio de alteração hidrotermal ocorrido ainda no Arqueano. Um cenário plausível é que, durante este primeiro evento, todos os minerais reativos para a formação do rutilo tenham sido consumidos. Logo, no caso da recorrência dos processos de alteração, rutilo não mais se formaria, embora seu sistema isotópico tenha sido afetado.

As conclusões a partir de um único dado devem ser tomadas com a devida cautela. Uma recomendação, para futuras investigações nesta linha, pode ser tomada do trabalho de Corfu \& Muir (1989). Partindo de uma análise muito discordante, os autores separaram frações menores de rutilo da mesma amostra, sob criteriosa classificação tipológica, obtendo resultados muito mais concordantes, especialmente para rutilos translúcidos onde a presença de inclusões pode ser detectada.

\subsubsection{Determinação U-Pb em titanita do gnaisse de Cocais}

A fração de titanita analisada forneceu idade mínima de $2.555 \mathrm{Ma}, 3,5 \%$ discordante (Tabela 20, figura 40). Tentativamente, este resultado poderia colocar-se em uma discórdia entre o Arqueano, há 2.800-2.700 Ma., e o Evento Transamazônico, ca. 2.050 Ma. Na hipótese de ser correta esta assertiva, ter-se-ia uma situação semelhante à dos gnaisses do Complexo Belo Horizonte, ou seja, o Evento Transamazônico como o principal episódio de retrabalhamento tectono-metamórfico das rochas arqueanas. 
Tabela 20: Resultados analíticos U-Pb para rutilo e titanita da região nordeste do Qudrilátero Ferrífero.

\begin{tabular}{|c|c|c|c|c|c|c|c|c|c|c|c|c|c|}
\hline \multicolumn{3}{|c|}{ A mostra } & \multicolumn{3}{|c|}{ Concentrações } & \multicolumn{5}{|c|}{ Razões Isotópicas } & \multicolumn{3}{|c|}{ Idades (Ma) } \\
\hline $\begin{array}{c}N^{\circ} \mathrm{da} \\
\text { amostra }\end{array}$ & $\underset{* 1}{\operatorname{Min} .}$ & Peso (mg) & $\begin{array}{l}\text { Urânio } \\
(\mathrm{ppm})^{* 2}\end{array}$ & $\begin{array}{l}\text { Pb rad. } \\
(\mathrm{ppm})^{* 2}\end{array}$ & $\begin{array}{c}\mathrm{Pb} \text { com. } \\
(\mathrm{pg})^{* 3}\end{array}$ & $\begin{array}{c}{ }^{206} \mathrm{~Pb} /{ }^{204} \mathrm{~Pb} \\
* 4\end{array}$ & ${ }^{208} \mathrm{~Pb} /{ }^{206} \mathrm{~Pb}^{* 5}$ & ${ }^{206} \mathrm{~Pb} /{ }^{238} \mathrm{U} * 5$ & ${ }^{207} \mathrm{~Pb} /{ }^{235} \mathrm{U} * 5$ & ${ }^{207} \mathrm{~Pb} /{ }^{206} \mathrm{~Pb} * \mathrm{~S}$ & ${ }^{206} \mathrm{~Pb} /{ }^{238} \mathrm{U}$ & ${ }^{207} \mathrm{~Pb}{ }^{235} \mathrm{U}$ & ${ }^{207} \mathrm{~Pb} /{ }^{206} \mathrm{~Pb}$ \\
\hline$\overline{\mathrm{CAE}-1}$ & $\overline{\mathrm{R}}$ & 0,1710 & 3,21 & 3,30 & 231 & 70 & 2,0106 & 0,37406 & 8,886 & 0,17230 & 2048 & 2326 & 2580 \\
\hline$M-88-8 \mathrm{c}$ & $T$ & 0,2800 & 78 & 42 & 1041 & 635 & 0,1423 & 0,46914 & 10,978 & 0,16972 & 2480 & 2521 & 2555 \\
\hline
\end{tabular}

*1- $\mathrm{R}=$ rutilo, $\mathrm{T}=$ titanita

*2- Concentrações são conhecidas com precisão de $2 \%$ para amostras pesando $0,4 \mathrm{mg}, 10-20 \%$ para amostras abaixo de $0,020 \mathrm{mg}$. Para amostras cujo peso está abaixo da sensibilidade da balança, $0,001 \mathrm{mg}$, as concentrações listadas são valores máximos.

$* 3$ - $\mathrm{Pb}$ comum total corrigido para o $\mathrm{Pb}$ comum do spike.

*4- Razão medida, corrigida apenas para o fracionamento.

*5- Razões corrigidas para o spike, fracionamento, branco e Pb comum inicial.

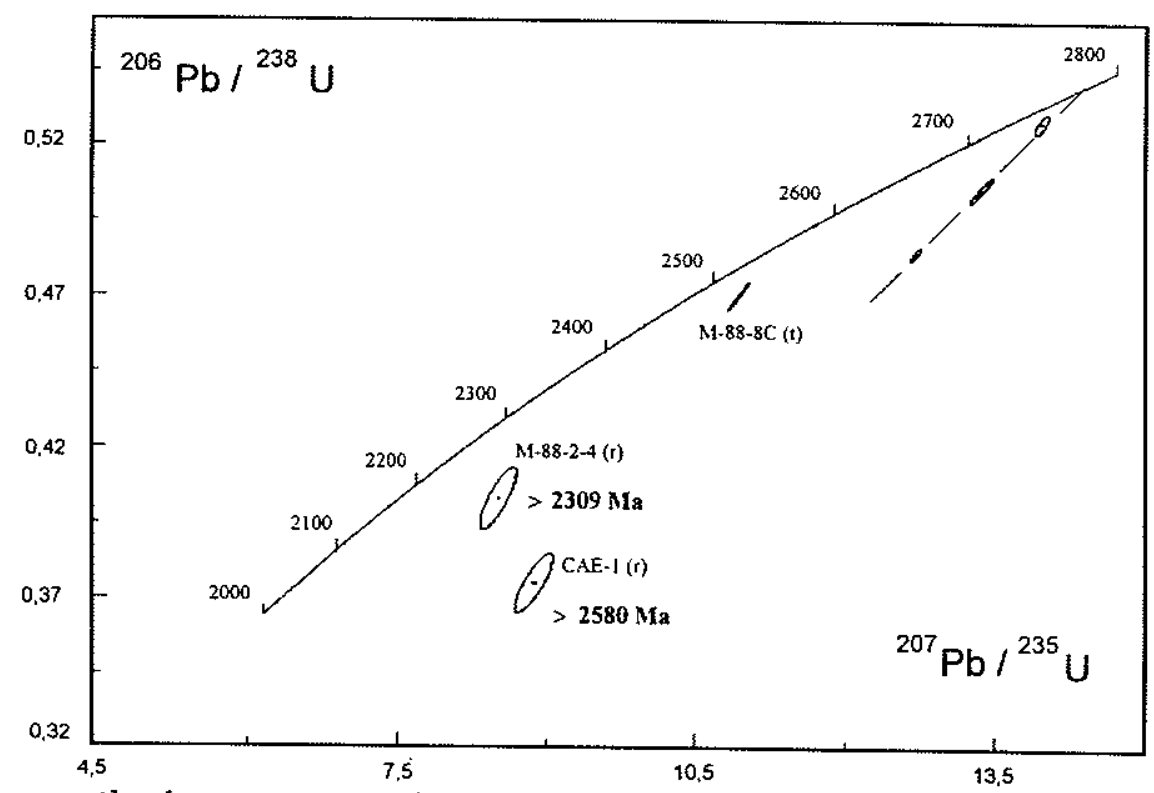

Figura 40: Diagrama concórdia para o rutilo da zona mineralizada no Grupo Nova Lima (CAE-1) e titanita da Pedreira de Cocais (M-88-8C). São também lançados a discórdia do Gnaisse de Caeté (intercepto superior a $2776 \mathrm{Ma}$ ) e o rutilo desta mesma rocha (M-88-2-4).

Legenda: $r=$ rutilo; $t=$ titanita. 


\subsection{DISCUSSÃO DOS RESULTADOS}

$O$ rutilo e a titanita analisados, ambos provenientes de zonas de cisalhamento, foram gerados em evento(s) metamórfico/metassomático(s) do Arqueano. Embora a estruturação da região em causa se deva, essencialmente, aos eventos tectônicos do Proterozóico (Belo de Oliveira \& Teixeira 1990, Chemale Jr. et al. 1991), algumas zonas de cisalhamento seriam estruturas arqueanas reativadas.

Os dados isotópicos para o rutilo indicam que o primeiro evento de cisalhamento/alteração hidrotermal na estrutura Geriza, com mineralização aurífera associada, é de idade arqueana. Tal conclusão é coerente com os resultados de determinações $\mathrm{Pb}-\mathrm{Pb}$ em sulfetos da Mina de São Bento (Dewitt et al. 1994), situada pouco a leste desta área. Admite-se que os processos metalogenéticos tenham sido recorrentes durante os eventos proterozóicos, de forma que a mineralização aurifera não pode ser atribuída a um único episódio. 


\section{CONCLUSÕES}

A tabela 21 apresenta um sumário dos dados geocronológicos obtidos neste trabalho. Nas próximas seções será discutida uma proposta de evolução geológica para a região do Quadrilátero Ferrífero, baseada nestes dados e no acervo geocronológico anterior. Discussões dessa natureza envolvem, inevitavelmente, apreciável parcela de especulação. Portanto, muitas das afirmações, ou suposições, contidas neste capítulo deverão ser encaradas como propostas ara investigações futuras.

\subsection{EVOLUÇÃO CUSTAL NO ARQUEANO}

\subsubsection{Formação dos primeiros núcleos continentais (3.300-3.000 Ma)}

As informações sobre os primeiros eventos de geração de crosta continental são fragmentárias e, frequentemente, indiretas. Tal fato é comum a todos os terrenos arqueanos existentes, já que o alto fluxo térmico e a grande mobilidade tectônica, vigentes naquela etapa da história da Terra, promoveram profunda reciclagem dos primeiros núcleos continentais. $\mathrm{O}$ sistema isotópico U-Pb do zircão, com frequêencia, é o único a conservar a "memória" desses eventos iniciais. Serão apresentadas, a seguir, algumas evidências da existência de núcleos continentais no período 3.300-3.000 Ma.

No Complexo Metamórfico Bonfim, Machado \& Carneiro (1992) obtiveram uma discórdia a partir de análises de núcleo e sobrecrescimento de zircão, extraídos do Gnaisse Alberto Flores. Apesar da discórdia ter sido traçada apenas por dois pontos, existe a indicação de que o protólito do gnaisse teria-se cristalizado por volta de $3.280 \mathrm{Ma}$. 
Tabela 21: Sumário dos dados geocronológicos obtidos neste estudo.

\begin{tabular}{|c|c|c|c|}
\hline Área/Litotipo & Método & Idade (Ma) & Interpretação \\
\hline $\begin{array}{l}\text { COMPLEXO BELO } \\
\text { HORIZONTE }\end{array}$ & & & \\
\hline \multirow[t]{4}{*}{ Gnaisse Belo Horizonte } & $\mathrm{U}-\mathrm{Pb}(\mathrm{z})$ & $2.860+14 /-10$ & migmatização \\
\hline & $\mathrm{Rb}-\mathrm{Sr}(\mathrm{rt})$ & $2.619 \pm 65$ & evento neo-arqueano (?) \\
\hline & $\mathrm{U}-\mathrm{Pb}(\mathrm{t})$ & $2.041 \pm 5$ & metamorfismo \\
\hline & $\mathrm{K}-\operatorname{Ar}(\mathrm{b})$ & $1.798 \pm 96$ & resfriamento transamazônico \\
\hline \multirow[t]{2}{*}{ Granito Santa. Luzia } & U-Pb (z) & $2.712+5 / .4$ & cristalização \\
\hline & $\mathrm{U} \cdot \mathrm{Pb}(\mathrm{t})$ & $-2.050(?)$ & metamorfismo \\
\hline Granito Córrego do Brumado & $\mathrm{U}-\mathrm{Pb}(\mathrm{m})$ & $\sim 2.045$ & cristalização \\
\hline Granito Morro da Pedra & $\mathrm{Pb}-\mathrm{Pb}(\mathrm{kf})$ & $2.227 \pm 490$ & cristalização (?) \\
\hline \multirow[t]{2}{*}{ Granito General Carneiro } & $\mathrm{Rb}-\mathrm{Sr}(\mathrm{rt})$ & $1.740 \pm 53$ & reativação mesoproterozóica \\
\hline & $\mathrm{K}-\operatorname{Ar}(\mathrm{b})$ & $1.007 \pm 35$ & eventos termais \\
\hline \multicolumn{4}{|l|}{$\begin{array}{c}\text { SUL DO QUADRILÁTERO } \\
\text { FERRÍFERO }\end{array}$} \\
\hline Granito Salto do Paraopeba & $\mathrm{U}-\mathrm{Pb}(\mathrm{z})$ & $2.612 \pm 5$ & cristalização \\
\hline Pegmatito de Salto & $\mathrm{Pb}-\mathrm{Pb}(\mathrm{h})$ & $2.236 \pm 200$ & cristalização \\
\hline \multirow[t]{4}{*}{ Batólito Alto Maranhão } & $\mathrm{U}-\mathrm{Pb}(\mathrm{z} / \mathrm{t})$ & $2.124 \pm 2$ & cristalização \\
\hline & Sm-Nd (TDM) & $2.110 \pm 57$ & extração do manto \\
\hline & $\mathrm{Rb}-\mathrm{Sr}(\mathrm{rt})$ & $664 \pm 80 / 484 \pm 37$ & rejuvenescimento brasiliano \\
\hline & $\mathrm{K}-\mathrm{Ar}(\mathrm{b})$ & $1.000 \pm 22 / 730 \pm 25$ & eventos termais \\
\hline Pegmatito Falha do Engenho & $\mathrm{U}-\mathrm{Pb}(\mathrm{m})$ & $\sim 596$ & cristalização \\
\hline \multicolumn{4}{|l|}{$\begin{array}{c}\text { NE DO QUADRILÁTERO } \\
\text { FERRÍFERO }\end{array}$} \\
\hline Gnaisse & $\mathrm{U}-\mathrm{Pb}(\mathrm{t})$ & $>2.555$ & \\
\hline Zona mineralizada & $\mathrm{U}-\mathrm{Pb}(\mathrm{r})$ & $>2.580$ & $\begin{array}{l}\text { idade minima mineralização } \\
\mathrm{Au}\end{array}$ \\
\hline
\end{tabular}

Nota: $z=z$ ircão, $t=$ titanita,$m=$ monazita, $k f=K$-feldspato, $h=$ hornblenda, $b=$ biotita; $r t=$ rocha total .

A sul do Quadrilátero Ferrífero, no domínio da Faixa Alto Rio Grande (região de Barbacena), Söllner el al. (1991) analisaram um gnaisse bandado que, segundo os autores, seria constituído pela alternância de bandas de origem vulcânica e bandas sedimentares. As distintas populações de zircão definiram uma idade de 3.399+114/-112 Ma para a área fonte dos zircões detríticos e $3.130 \pm 8$ Ma para o evento vulcânico. 
O Greenstone Belt de Piumhí apresenta uma seqüência basal composta, essencialmente, por rochas vulcânicas e vulcanoclásticas, de composição ultramáfica a máfica, e sedimentos de composição máfica subordinados (Schrank 1982; Jahn \& Schrank 1983). Na sua porção mais inferior, derrames komatíticos exibem sills estratificados de composição máfica a ultramáfica. Um meta-gabro anortosítico, proveniente de um dos sills, continha poucos zircões de uma só tipologia, cuja análise forneceu uma discórdia com intercepto superior a 3.116+10/-7 Ma. (Machado \& Schrank 1989). Esta idade deve datar a geração do pacote vulcânico.

O ambiente geotectônico de formação dos greenstone belts é um assunto controverso; considerando-se apenas os modelos de tectônica de placas, greenstone belts têm sido relacionados a todos os ambientes possíveis (e.g. Windley 1984). As unidades máficoultramáficas basais dos greenstone belts mais antigos (>3.000 Ma) poderiam representar remanescentes de crosta oceânica (e.g. De Wit et al. 1987). Neste caso, a existência de blocos continentais contemporâneos ao Greenstone Belt de Piumhí não está implícita. Entretanto, rochas gnáissicas expostas a algumas dezenas de $\mathrm{km}$ a leste, no Complexo Campo Belo, exibem as idades Rb-Sr mais elevadas conhecidas no setor meridional do Cráton do São Francisco. Parte da crosta siálica aí presente formou-se durante o intervalo 3.380-3.310 Ma (Teixeira et al. 1994).

A idade mais antiga registrada para os zircões detríticos das unidades supracrustais do Quadrilátero Ferrífero foi $3.227 \pm 38 \mathrm{Ma}$. Do conjunto de 110 grãos analisados, foi obtido apenas mais um valor acima de $3.100 \mathrm{Ma}(3.130 \pm 38 \mathrm{Ma})$ e três entre 3.100 e $3.000 \mathrm{Ma}$. Ainda na região do Quadrilátero Ferrífero, próximo a Caeté, Machado et al. (1992) dataram um metariolito em $3.029 \mathrm{Ma}$.

O Complexo Campo Belo parece constituir o único fragmento continental cuja formação inicial pode ser atribuída ao período 3.300-3.000 Ma. Em outras áreas, a presença de crosta continental desta idade é apenas vestigial, face aos dados existentes. Entretanto, núcleos continentais primitivos atribuídos ao período em causa, ou mesmo mais antigos, são bem conhecidos no setor setentrional do Cráton do São Francisco (Teixeira 1993). De fato, é exatamente a partir de $3.300 \mathrm{Ma}$ que o crescimento de crosta continental parece experimentar uma aceleração em escala mundial (e.g. Goodwin 1991).

\subsubsection{Crescimento Continental e Eventos Tectono-Termais (3.000-2.850 Ma)}

O histograma de distribuição das idades de zircão detrítico (Figura 36) exibe um aumento dos dados a partir de 3.000 Ma., com o máximo posicionado em torno de 2.850 Ma. Eventos 
nesta faixa de idades são conhecidos no embasamento do Supergrupo Espinhaço, exposto a sul de Diamantina ("Janela" de Gouveia), e no Complexo Belo Horizonte.

$\mathrm{Na}$ "Janela" de Gouveia, o complexo granito-gnáissico apresenta idade um tanto incerta, mas no intervalo 3.000-2.840 Ma (Machado et al. 1989b, Machado \& Noce 1993). A idade mais nova representa a intrusão do Granito de Gouveia em $2.839 \pm 14 \mathrm{Ma}$ (Machado et al. 1989b) Na mesma área, um metariolito da sequência vulcano-sedimentar do Supergrupo Rio Paraúna forneceu uma discórdia com intercepto superior a 2.971 $\pm 16 \mathrm{Ma}$ (Machado et al. 1989b).

A maior parte do Complexo Belo Horizonte é formada por rochas gnáissicas (Gnaisse Belo Horizonte) constituindo uma suíte TTG. O gnaisse sofreu importante evento tectono-termal por volta de 2.860+14/-10 Ma, sendo parcialmente migmatizado. Informações adicionais sobre o Complexo Belo Horizonte são fornecidas pelas análises de zircão detrítico das amostras da Formação Moeda (amostra QF-1) e Grupo Sabará (amostra SAB), cuja área-fonte provável foi o próprio complexo. Cerca de $60 \%$ dos zircões detríticos da Formação Moeda e $45 \%$ da Formação Sabará exibem idades que, na faixa de erro, apresentam superposição no período $2.860+14 /-10$ Ma. Outros $22 \%$ dos zircões do conjunto das duas amostras posicionam-se no intervalo 3.000 $2.900 \mathrm{Ma}$. Adicionalmente, o mobilizado migmatítico analisado possuía zircão herdado com idade mínima de 2.922 Ma. Existe, portanto, a sugestão de que o protólito do Gnaisse Belo Horizonte foi gerado em um evento magmático ocorrido entre 3.000-2.900 Ma e, posteriormente, deformado e migmatizado em um evento cujo paroxismo ocorreu em 2.860+14/-10 Ma.

Entretanto, a duração de eventos metamórficos, no Arqueano, pode ser excepcionalmente longa. Wiedenbeck (1990) demonstrou, em uma área do Cráton Yilgarn (Austrália), que condições metamórficas de grau elevado, responsáveis por crescimento de zircão, prolongaramse por cerca de $100 \mathrm{Ma}$. Caso tal situação tenha se reproduzido no Complexo Belo Horizonte, os zircões na faixa de 3.000-2.900 Ma poderiam ainda estar relacionados ao evento metamórfico, sendo o protólito do gnaisse mais antigo.

É difícil avaliar a extensão da crosta continental formada até $2.850 \mathrm{Ma}$. Um possível cenário é que esta se encontrasse dividida em número incerto de blocos. Por exemplo, processos geológicos comuns ao conjunto do embasamento arqueano do Quadrilátero Ferrífero são registrados somente depois de $2.780 \mathrm{Ma}$. Portanto, é possível que, em época anterior, porções desse embasamento ainda evoluíssem de forma independente.

\subsubsection{Eventos do Neoarqueano (2.800-2.600 Ma)}

Os eventos do Neoarqueano parecem resultar da progressiva aglutinação de blocos continentais, promovendo intenso retrabalhamento da crosta continental formada anteriormente, 
associado à adição de material juvenil. A evolução do Greenstone Belt Rio das Velhas relacionase a um desses eventos.

\subsubsection{OEvento de 2780-2700 Ma (Evento Rio das Velhas)}

Esta designação foi proposta por Carneiro (1992). Trata-se do evento arqueano mais bem caracterizado na região do Quadrilátero Ferrifero, face ao volume de idades U.Pb relativas a este (Machado et al. 1992, Machado \& Carneiro 1992, Carneiro 1992). Outrossim, diversas isócronas $\mathrm{Rb}$-Sr demonstram a extensão deste evento por grandes áreas do embasamento meridional do Cráton do São Francisco (Teixeira 1985, 1993).

A primeira fase do Evento Rio das Velhas ocorreu ao redor de 2.780-2.770 Ma. No Complexo Bonfim, registra-se o retrabalhamento (metamorfismo) da crosta siálica antiga, representada pelo Gnaisse Alberto Flores, em 2.772 $\pm 6 \mathrm{Ma}$, simultaneamente à intrusão de corpos tonalíticos volumetricamente importantes (Tonalitos Samambaia, 2.780+3/-2 Ma) e ao vulcanismo félsico no âmbito do Greenstone Belt Rio das Velhas (2.772 $\pm 6 \mathrm{Ma})$. As idades referidas são determinações U-Pb de Machado et al. (1992) e Machado \& Carneiro (1992). Idades-modelo (TDM) Sm-Nd para os Tonalitos Samambaia indicam que um dos corpos originou-se do manto por volta de $2.780 \mathrm{Ma}$, enquanto o outro incorporava componente crustal bem mais antigo, de $2.940 \mathrm{Ma}$ (Teixeira et al. 1994).

No Complexo Caeté, plutonismo granodiorítico há $2.776+7 /-6 \mathrm{Ma}$ foi também contemporâneo do vulcanismo félsico na faixa adjacente do Greenstone Belt Rio das Velhas (2.776+23/-10 Ma; Machado et al. 1992).

O Granito Mateus Leme, a noroeste do Quadrilátero Ferrífero, exibe idade U-Pb de $2.755 \pm 13 \mathrm{Ma}$, muito próxima da idade-modelo $\mathrm{Sm-Nd}$ (TDM) de 2.780 Ma (Romano 1989, Romano et al. 1991).

A fase final do Evento Rio das Velhas ocorreu entre 2.720-2.700 Ma, com a intrusão de corpos granitóides de dimensões limitadas. No Complexo Bonfim são conhecidos o Granodiorito Mamona (2.721 $\pm 3 \mathrm{Ma}$; Machado et al. 1992) e o Granito Brumadinho (2.703+24/-20 Ma; Machado \& Carneiro 1992). Estes corpos apresentam características de intrusões pós-tectônicas ou mesmo anorogênicas (Carneiro 1992, Lacerda et al. 1993). Nessa mesma época, ocorreu a intrusão, no Complexo Belo Horizonte, do Granito Santa Luzia $(2.712+5 / .4 \mathrm{Ma})$, Granito General Carneiro e Granodiorito Ibirité (2.698 $18 \mathrm{Ma}$, Chemale Jr. et al. 1993).

A assinatura geoquímica e idade-modelo $\mathrm{Sm}-\mathrm{Nd}$ (TDM), esta última para o Granito Brumadinho (Teixeira et al. 1994), relacionam os granitóides de 2.720-2.700 Ma a processos de 
retrabalhamento crustal. Estes corpos representam o último evento de granitogênese arqueana determinado até o presente para a região setentrional do Quadrilátero Ferrífero.

Diversas isócronas $\mathrm{Rb}$-Sr, obtidas para o Complexo Belo Horizonte e áreas a oeste deste (Teixeira 1985, Teixeira et al. 1994), forneceram idades entre 2.650 e 2.800 Ma. Estes dados, associados à intrusão do Granito Santa Luzia, demonstram a atuação do Evento Rio das Velhas no Complexo Belo Horizonte.

Pode-se interpretar o evento de 2.780-2.700 Ma à luz da evolução do Greenstone Belt Rio das Velhas. O metavulcanito félsico datado na região do Complexo Bonfim (na localidade de Piedade do Paraopeba), ocorre imediatamente acima de um pacote vulcânico máfico-ultramáfico (Noce et al. 1992). Portanto, é possível que não seja grande o intervalo temporal entre o vulcanismo toleiítico-komatítico da base da seqüência e o vulcanismo félsico de $2.772 \pm 6 \mathrm{Ma}$. Especulativamente, o vulcanismo e sedimentação do greenstone teriam evoluído, a partir dessa época, no âmbito de um processo de fechamento oceânico e colisão continental (Carneiro 1992), o que é reforçado pela associação temporal com retrabalhamento crustal e intrusões tonalíticas. $\mathrm{O}$ processo colisional completar-se-ia antes, ou por volta de $2.700 \mathrm{Ma}$, com a intrusão de granitos tardi a pós-orogênicos. O intervalo de tempo de cerca de $70 \mathrm{Ma}$ é bastante semelhante, por exemplo, àquele requerido para a evolução da porção sul do Greenstone Belt Abitibi (Corfu 1993).

As manifestações plutônicas relativas ao Evento Rio das Velhas evidenciam, no caso dos granitóides gerados por volta de $2.780-2.770 \mathrm{Ma}$, tanto a contribuição juvenil quanto o retrabalhamento da crosta primitiva. Os granitóides de idade 2.720-2.700 Ma são, volumetricamente, menos expressivos e possuem origem crustal. Este trend deve refletir o processo progressivo de cratonização.

Um fato notável acerca do Evento Rio das Velhas é sua contemporâneidade com episódios tectono-magmáticos de grande magnitude, registrados em outras áreas arqueanas. Cita-se, por exemplo, a Província Superior (Canadá) e o Cráton Yilgarn (Austrália).

\subsubsection{Eventos magmáticos finais e a consolidação da plataforma arqueana}

O Evento Rio das Velhas parece ter culminado com a estabilização de uma plataforma de extensão considerável, possivelmente com dimensões comparáveis às do Bloco Pilbara na Austrália (Machado \& Noce 1993). Esta plataforma, atualmente, compreende a porção exposta do embasamento meridional do Cráton do São Francisco e também parte da infraestrutura das 
faixas marginais, como já havia sido demonstrado por Teixeira (1985). O período final de cratonização incluiu manifestações isoladas de magmatismo, representadas pela intrusão do

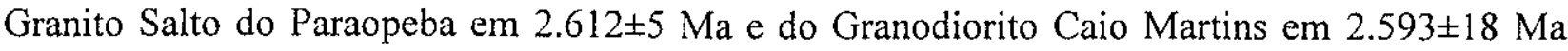
(Romano 1989, Romano et al. 1991).

Estes granitóides tardios podem derivar de algum evento episódico em torno de 2.610-2590 $\mathrm{Ma}$, ou estariam ainda no contexto da evolução do evento anterior. Corfu $(1987,1988)$ demonstrou que, durante o Arqueano, processos magmáticos e metamórficos, nas porções mais inferiores da crosta, podem continuar atuantes por longos períodos subsequentes ao término dessas atividades na crosta superior granito-greenstone.

\subsection{CiClo TRANSAMAZÔNICO (PALEOPROTEROZÓICO): EVOLUÇÃo DO SUPERGRUPO MINAS}

O Ciclo Transamazônico é expresso por uma série de processos tectônicos, sedimentares e magmáticos, desenvolvidos sobre uma plataforma continental consolidada ca. 2.600 Ma. Esses processos culminaram em um evento colisional cujo término ocorreu ca. 2.000 Ma.

A sedimentação do Supergrupo Minas iniciou-se, possivelmente, por volta de $2.575 \pm 15$ $\mathrm{Ma}$, em proto-bacias geradas pelo rifteamento incipiente da plataforma arqueana (Renger et al. 1994). Esse periodo inicial é representada pela deposição da Formação Moeda. Seguiu-se um período de estabilidade tectônica, marcado pela deposição dos sedimentos plataformais que constituem as formações Batatal, Cauê e Gandarela Esta última tem sua deposição balizada pela

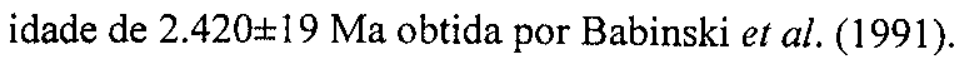

O início da sedimentação do Grupo Piracicaba, por volta de $2.400 \mathrm{Ma}$, associa-se a um período de instabilidade tectônica da bacia, com manifestações vulcânicas contemporâneas. Especula-se que esse período possa marcar o início de um processo de abertura oceânica. A abertura teria ocorrido a leste e sul do Quadrilátero Ferrifero, mas seus reflexos provocariam a movimentação de blocos durante a sedimentação basal do Grupo Piracicaba.

Em algum momento dessa evolução, possivelmente após a sedimentação do Grupo Piracicaba, o contexto geodinâmico torna-se compressivo. Tem início a subducção da crosta oceânica formada anteriormente, o que é refletido pela intrusão do Batólito Alto Maranhão a $2.124 \pm 2 \mathrm{Ma}$. 
O processo culmina em um evento colisional, supostamente entre 2.065-2.035 Ma. Esta idade advém das dataçōes de titanitas do embasamento do Quadrilátero Ferrífero, indicando a reativação dos terrenos arqueanos. Em vários cinturões tem sido demonstrada a correlação de processos de reativação do embasamento com eventos de colisão continental (e.g. Machado et al 1989c).

A Formação Sabará corresponderia à sedimentação sin-orogênica (flysh) do Evento Transamazônico, sucedida pela sedimentação molássica representada pelo Grupo Itacolomi.

\subsubsection{Considerações sobre a natureza da tectônica transamazônica}

A natureza da tectônica transamazônica no Quadrilátero Ferrífero, extensional ou compressional, tem suscitado controvérsias (Marshak \& Alkmim 1989, Belo de Oliveira \& Teixeira 1990, Chemale Jr. et al. 1991, 1994). Alguma luz sobre este tema pode advir do estudo do overprint metamórfico transamazônico impresso no embasamento arqueano do Quadrilátero Ferrífero, especialmente através das determinações U-Pb em titanita. A oeste, no Complexo Bonfim, as titanitas preservam a idade arqueana (Machado \& Carneiro 1992). Na porção central do Quadrilátero Ferrífero, complexos Belo Horizonte e Bação, as titanitas sofreram resetting parcial a total (ou neo-formação) entre 2.065-2.035 Ma. A leste, as rochas arqueanas foram submetidas a metamorfismo no fácies granulito durante o Evento Transamazônico (isócronas Rb$\mathrm{Sr}$ e $\mathrm{Pb}-\mathrm{Pb}$ de Teixeira et al. 1987).

Esse conjunto de dados é coerente com o aumento progressivo do overprint metamórfico transamazônico sobre o embasamento arqueano do Quadrilátero Ferrífero, da fácies xisto-verde a oeste a fácies anfibolito na porção central e fácies granulito a leste. Polaridade semelhante está registrada no Supergrupo Minas, atingindo o grau anfibolito (Herz 1978, Roeser et al. 1987). No entender do autor, um evento metamórfico dessa natureza, afetando o embasamento/cobertura dentro de um padrão regional razoavelmente bem definido é, classicamente, associado a espessamento crustal em regime compressivo. Este teria ocorrido como reflexo da colisão transamazônica em curso a leste e sudeste do Quadrilátero Ferrífero.

Dois dados isotópicos obtidos diretamente em rochas do Supergrupo Minas, ou em corpos intrusivos neste, endossam o posicionamento da deformação/metamorfismo principais no Evento Transamazônico. Estes são as idades isocrônicas $\mathrm{Pb}-\mathrm{Pb}$ de $2.050 \pm 230 \mathrm{Ma}$, em carbonatos deformados do Grupo Piracicaba (Babinski et al. 1991), e 2.236 200 Ma obtida em pegmatitos foliados cortando a Formação Moeda. 
É possível que as estruturas extensionais, bem evidenciadas no domínio ocidental do Quadrilátero Ferrífero (Chemale Jr. et al. 1991, 1994), tenham resultado da reversão do regime tectônico ao final da Orogênese Transamazônica. De fato, Marshak et al. (1992) afirmam que o processo de ascenção dos blocos do embasamento, ocorrendo dentro do contexto da tectônica extensional, afetou rochas do Supergrupo Minas previamente foliadas e submetidas a metamorfismo na fácies xisto verde baixo. Marchak et al. (1992) atribuem o evento extensional e de diapirismo ao Ciclo Espinhaço. Entretanto, pequenos corpos granitóides (granitos Morro da Pedra e Córrego do Brumado no Complexo Belo Horizonte) e lentes pegmatíticas (Complexo Bação), datados entre 2.045 e $2.030 \mathrm{Ma}$, poderiam ter resultado desse processo, confirmando seu posicionamento ao final da Orogênese Transamazônica.

\subsubsection{Uma visão regional do cinturão transamazônico (Cinturão Mineiro)}

A região estudada neste trabalho corresponde a um pequeno setor de extenso cinturão transamazônico, designado Cinturão Mineiro por Teixeira (1985). Este cinturão descreve um arco que conforma a borda sul do Cráton do São Francisco assumindo, na região do Quadrilátero Ferrífero, orientação próxima a N-S. A reconstituição geotectônica do Cinturão Mineiro é tarefa complexa, seja pelas deficiências no conhecimento geológico-geocronológico de diversas áreas, seja pela retomada tectônica posterior, especialmente no Evento Brasiliano. O desenvolvimento de um arco magmático plutônico no segmento meridional do cinturão encontra-se bem documentado em termos radiométricos (Teixeira 1985, Quéméneur \& Vidal 1989, Heilbron et al. 1989, Teixeira \& Figueiredo 1991, Choudhuri et al. 1992, Quéméneur \& Garcia 1993). O arco magmático deve continuar pela região a leste do Quadrilátero Ferrifero, conforme preconizado pelo modelo exposto no capítulo 5 deste trabalho. Entretanto, os diversos corpos granitóides descritos nesta região (Brandalise 1991, Baltazar \& Barroso 1993) carecem de determinações geocronológicas.

Os granitóides transamazônicos, segundo Teixeira \& Figueiredo (1991), são predominantemente de derivação crustal e definem um trend entre tipos cálcio-alcalinos sin a pós-colisionais. Entretanto, existem outros que denotam o consumo de crosta oceânica, como o Batólito Alto Maranhão $(2.124 \pm 2 \mathrm{Ma})$, a sul do Quadrilátero Ferrífero. Este corpo, de composição predominantemente tonalítica, é quimicamente semelhante aos granitóides de derivação mantélica posicionados em zonas ativas de margem de placa. Desse modo, os diversos granitóides transamazônicos exprimem diferentes estágios na evolução de uma colisão continental. 
A continuação setentrional da infraestrutura do Cinturão Mineiro encontra-se obscurecida pelos eventos tectônicos e seqüências supracrustais mais novas. Não obstante, idades transamazônicas têm sido obtidas para o embasamento do Supergrupo Espinhaço e grupos Macaúbas e Bambuí, na região centro-norte do Estado de Minas Gerais. Cita-se, por exemplo, as idades Rb-Sr em torno de $2.000 \mathrm{Ma}$ no Complexo Itacambira-Barrocão (Siga Jr. 1986) e na região de Januária (Besang et al. 1977). Na região de Diamantina, uma metavulcânica félsica da Formação Barão de Guacuí (Fogaça et al. 1984) foi datada por U-Pb em 2.049+3/-2 Ma (Machado et al. 1989b). Esta formação, originalmente colocada no Supergrupo Rio Paraúna (Fogaça et al. 1984), de idade arqueana, constitui portanto uma unidade supracrustal associada ao Ciclo Transamazônico, depositada no período sin-colisional.

O conhecimento do Cinturão Mineiro a norte do Quadrilátero Ferrífero, ainda que muito fragmentário, sugere sua continuidade com o Cinturão Transamazônico Ocidental no Estado da Bahia (Cinturão Correntina-Guanambi, Teixeira \& Figueiredo 1991). A leste deste estende-se outro cinturão transamazônico (Cinturão Itabuna, Teixeira \& Figueiredo 1991), separado por um bloco cratônico arqueano. $\mathrm{O}$ acervo geocronológico para os cinturões transamazônicos da parte setentrional do Cráton do São Francisco é bem mais rico que aquele do Cinturão Mineiro, permitindo caracterizar uma complexa sucessão de eventos entre 2.400 e $1.900 \mathrm{Ma}$ (Teixeira 1993, Barbosa 1993). Alguns dados evidenciam marcante sincronia com os eventos registrados no Cinturão Mineiro, como as idades U-Pb do metamorfismo superimposto à rochas arqueanas no domínio do Cinturão Itabuna, obtidas por Ledru et al. (1993), entre 2.105-2.065 Ma (2.0652.035 no Quadrilátero Ferrífero). Os processos colisionais finais, ao longo de toda a extensão dos cinturões, encerram-se por volta de 2.000 Ma (Barbosa 1993).

Face às consideração anteriores, imagina-se para a Orogênese Transamazônica um papel semelhante ao exercido pela Orogênese Trans-Hudsoniana (ca. 1.800 Ma) na América do Norte. Esta engloba uma série de cinturões orogênicos, interconectados, que derivam da amalgamação da grande massa continental da Laurentia a partir de vários núcleos cratônicos menores (Hoffman 1988).

\subsection{EVOLUÇÃO MESO E NEOPROTEROZÓICA}

A área continental estabilizada ao final do Evento Transamazônico, ca 2.000 Ma, registra seu primeiro evento importante a 1.750-1.710 Ma, idade do vulcanismo e plutonismo félsico associado ao desenvolvimento da fase rift de deposição do Supergrupo Espinhaço (Machado et 
al. 1989b, Almeida-Abreu 1993, Dossin et al. 1993). Eventos distensivos dessa faixa de idade, na região do Quadrilátero Ferrífero, são evidenciados pelos enxames de diques máficos datados por Teixeira et al. (1988).

O Evento Brasiliano, ao final do Proterozóico, teve papel fundamental na estruturação de larga parcela do continente sul-americano (e.g. Brito Neves \& Cordani 1991). No âmbito das análises realizadas neste trabalho, apenas os dados $\mathrm{Rb}$-Sr para o Batólito Alto Maranhão registram rejuvenescimento isotópico brasiliano. Soma-se a estes a idade de $596 \mathrm{Ma}$ dos veios quartzo-feldspáticos da Falha do Engenho. As determinações K-Ar em biotita, na sua maioria, mostram apenas rejuvenescimentos parciais devidos à influência termal do Evento Brasiliano.

Uma questão que se coloca é como conciliar o papel da tectônica brasiliana na estruturação do Quadrilátero Ferrífero, preconizado pelos modelos de vários autores (Marshak \& Alkmim 1989, Belo de Oliveira \& Teixeira 1990, Chemale Jr. et al. 1994, etc.), com a escassez de registro isotópico relativo a esse evento. A princípio, o autor encampa a proposta de Belo de Oliveira \& Teixeira (1990), segundo a qual o front principal da deformação brasiliana, no Quadrilátero Ferrifero, situa-se ao longo da Falha de Morro Vermelho (ou Sistema Cambotas-Fundão de Chemale Jr. et al. 1991). Todas as determinações $\mathrm{U}-\mathrm{Pb}, \mathrm{Pb}-\mathrm{Pb}$ e $\mathrm{Rb}-\mathrm{Sr}$ (isócronas em rocha total), bem como parte das idades K-Ar, obtidas a oeste deste sistema de falhamento, são prébrasilianas. Entretanto, o mesmo também ocorre para as idades $\mathrm{Rb}-\mathrm{Sr}$ e $\mathrm{Pb}-\mathrm{Pb}$ disponíveis logo a leste do Quadrilátero Ferrífero (Teixeira et al. 1987). Isto poderia caracterizar o Evento Brasiliano, no Quadrilátero Ferrífero, como um evento de tectonismo reflexo, em baixas temperaturas, principalmente atuando na reativação de estruturas pré-existentes. Toma-se, como exemplo, a Falha do Engenho. Indícios de atividade deste falhamento já são registrados durante a sedimentação do Supergrupo Minas (Weiss 1989). Sua reativação, no Evento Brasiliano, é bem demonstrada pela idade de $596 \mathrm{Ma}$ dos veios com monazita.

$\mathrm{O}$ valor de $596 \mathrm{Ma}$ soma-se às idades U-Pb de $635 \pm 2 \mathrm{Ma}$ para um corpo subvulcânico de traquito da região de Piumhi (Machado \& Schrank 1989) e 512 55 Ma para um mobilizado félsico do embasamento a leste da Serra do Espinhaço Meridional (Machado et al. 1989b). Constata-se que o Evento Brasiliano, nas faixas marginais à borda meridional do Cráton do São Francisco, teve duração superior a $100 \mathrm{Ma}$, envolvendo uma sucessão de processos cuja cronologia e caracterização encontram-se ainda por determinar. 


\section{REFERÊNCIAS BIBLIOGRÁFICAS}

ALEINIKOFF, IIN. \& GRACH, R.I. 1990. U-Pb geochronologic constraints on the origin of a unique monazite-xenotime gneiss, Hudson highlands, New York. American Journal of Science, 290:522-546.

ALKMIM, F.F. 1985. Sedimentologische, lithoestratographische und tektonische Untersuchungen in der Serra de Ouro Branco, Minas Gerais. Brasilien. Clausthal, 217p. (Tese de Doutoramento, Technischen Universität Clausthal).

ALKMIM, F.F.; BRITO NEVES, B.B.; CASTRO ALVES, J.A. 1993. Arcabouço tectônico do Cráton do Săo Francisco-uma revisão. In: DOMINGUEZ, J.M.L \& MISI, A. (eds), O Cráton do São Francisco. Salvador, SBG-SGM-CNPq, p.45-62.

ALMEIDA, F.F.M. de. 1977, O Cráton do São Francisco. Revista Brasileira de Geociencias, 7(4):349-364.

ALMEIDA, F.F.M. de \& HASUI, Y. 1984. O PréCambriano do Brasil. São Paulo, Ed. Edgard Blucher, $378 \mathrm{p}$.

ALMEIDA-ABREU, P.A. 1993. A evolução geodinâmica da Serra do Espinhaço Meridional, Minas Gerais, Brasil. Freiburg i. Br., 150p. (Tese de Doutoramento, Albert-Ludwigs-Universität).

ARROWSMITH, P. 1987. Laser ablation of solids for elemental analysis by inductively coupled plasma mass spectrometry. Analytical Chemistry, 59:1437. 1444.

BABINSKI, M.; CHEMALE JR., F.; VAN SCHMUS, W.R. 1991. Geocronologia $\mathrm{Pb} / \mathrm{Pb}$ em rochas carbonáticas do Supergrupo Minas. Quadrilátero Ferrifero, Minas Gerais. Brasil. In: CONGRESSO BRASILEIRO DE GEOQUÍMICA, 3, Ouro Preto, 1991. Anais... Ouro Preto, SBGq, v.1, p.628-631.

BABINSKI, M.; CHEMALE JR., F.; VAN SCHMUS, W.R. 1993. $A$ idade das formações ferríferas bandadas do Supergrupo Minas e sua correlação com aquelas da África do Sul e Austrália. In: SIMPÓSIO SOBRE O CRÁTON DO SÃO FRANCISCO, 2, Salvador, 1993. Anais... Salvador, SBG/SGM, p.152-153.

BALTAZAR, O.F. \& RAPOSO, F. 1993. Programa levantamentos geológicos básicos do Brasil. MarianaFolha SF 23-X-B-1. Estado de Minas Gerais. Escala 1:100.000. Brasilia. DNPM/CPRM. 196p.

BARBOSA, A.L.M. 1968. Contribuiçŏes recentes à geologia do Quadrilátero Ferrífero. IGC-UFMG (1985), 44p.
BARBOSA. G.V. 1980. Supertǐcies de crosão no Quadrilátero Ferrifero, Minas Gerais. Revista Brasileira de Geociências, 10(1):89-101.

BARBOSA. J.S.F. 1993. O embasamento do Cráton do São Francisco na Bahia: sintese do conhecimento atual. In: SIMPÓSIO SOBRE O CRÁTON DO SÃO FRANCISCO, 2, Salvador, 1993. Anais... Salvador, SBG/SGM. p.9-11.

BARBOSA. M. I. M. 1985. Geoquimica das faixas máficas-ultramáficas, plutonitos e migmatitos do "Greenstone Belt" Barbacena, na região de Conselheiro Lafaiete (MG). Rio de Janeiro, $185 \mathrm{p}$. (Dissertação de Mestrado. Universidade Federal do Rio de Janeiro)

BARBOSA, O. 1949. Contribuiçào à geologia do centro de Minas Gerais. Mineração e Metalurgia, 14(79):3-19.

BARBOSA, O. 1954. Évolution du Géosynclinal Espinhaço. In: INTERNATIONAL GEOLOGICAL CONGRESS, Argel, 1952. Comptes Rendus... Argel, sec. XII, p.2-33.

BARKER, F. 1979. Trondhjemite: definition, environment and hypothesis of origin. In: BARKER, F. (ed), Trondhjemites, Dacites and Related Rocks. Amsterdan, Elsevier. p. 1-12.

BATCHELOR, R.A \& BOWDEN, P. 1985. Petrogenetic interpretation of granitoid rock series using multicationic parameters. Chemical Geology, 48:4355 .

BELO de OLIVEIRA, O.A. \& VIEIRA, M.B.H. 1987. Aspectos da deformação dúctil e progressiva no Quadrilátero Ferrifero. In: SIMPÓSIO DE GEOLOGIA DE MINAS GERAIS, 4, Belo Horizonte. 1987. Anais... Belo Horizonte, SBG-MG, p.237-252 (Boletim 5).

BELO de OLIVEIRA, O.A.; GRECO, F.M.; VIEIRA, M.B.H. 1987. A relaçăo da tectônica Espinhaço Meridional - Quadrilátero Ferrifero. In: SIMPÓSIO NACIONAL DE ESTUDOS TECTÔNICOS, 1, Salvador, 1987. Boletim de Resumos...SBG-BA/SE, p.74-76.

BELO de OLIVEIRA. O.A. \& TEIXEIRA, W. 1990. Evidências de uma tectônica tangencial proterozóica no Quadrilátero Ferrífero, MG. In: CONGRESSO BRASILEIRO DE GEOLOGIA, 36, Natal. 1990. Anais...Natal, SBG, p.2589-2603.

BELO de OLIVEIRA, O.A.; VIEIRA, M.B.H.: GRECO, F.M. 1990. Alteração hidrotermal relacionada a zonas de cisalhamento dúctil em depósitos auriferos no Quadrilátero Ferrifero. In: CONGRESSO BRASILEIRO DE GEOLOGIA, 36, Natal, 1990. Boletim de Resumos...Natal, SBG, p, 101.

BESANG. C.: EBERLE. W.G.: LAHNER. L.: LENZ. H.: MOLLAT. H.; MÜLLER, P.; PAULSEN, S. 1977. Radiometrishe Altersbestimmungen an Gesteinen aus Minas Gerais und Espirito Santo/Brasilien. Geologische Jarbuch, B24:149-179. 
BRANDALISE, L.A. 1991. Programa levantamentos geológicos básicos do Brasil. Ponte Nova-Folha SF.23-X-B-Il. Estado de Minas Gerais. Escala 1:100.000. Belo Horizonte. DNPM/CPRM, 194p.

BRITO-NEVES, B.B.; KAWASHITA. K.: CORDANI, U.G.; DELHAL, J. 1979. A evolução geocronológica da Cordilheira do Espinhaço; dados novos a integração. Revista Brasileira de Geociências, 9:7185.

BRITO-NEVES, B.B.; TEIXEIRA, W:; TASSINARI. C.C.G.; KAWASHITA, K. 1990. A contribution to the subdivision of the Precambrian in South America. Revista Brasileira de Geociências, 20:267-276.

BRITO-NEVES, B.B. \& CORDANI, U.G. 1991. Tectonic evolution of South America during the Late Proterozoic. Precambrian Research, 53:23-40.

CAMERON, A.E.; SMITH, D.H.; WALKER, R.L. 1969. Mass spectrometry of nanogram-size samples of lead. Analytical Chemistry, 41:525-526.

CARIGNAN, J.; MACHADO, N.; GARIÉPY, C. 1993a. $\mathrm{Pb}$ isotope composition of $\mathrm{Ni}-\mathrm{Cu}-\mathrm{Pb}$ deposits in an Archean greenstone belt: Evidence for Proterozoic remobilization in the Pontiac Subprovince of Canada. Economic Geology, 88:709-715.

CARIGNAN, J.; GARIÉPY, C.; MACHADO, N.; RIVE, M. $1993 \mathrm{~b} . \mathrm{Pb}$ isotopic geochemistry of granitoids and gneisses from the late Archean Pontiac and Abitibi Subprovinces of Canada. Chemical Geology, 106(3/4):299-316.

CARNEIRO, M.A. 1992. O Complexo Metamórfico Bonfim Setentrional (Quadrilátero Ferrifero, Minas Gerais): Litoestratigrafia e evolução geológica de um segmento de crosta continental do Arqueano. São Paulo, 233 p. (Tese de Doutoramento, Universidade de São Paulo).

CARNEIRO, M.A. \& TEIXEIRA, W. 1992. Discordância de idades radiométricas $\mathrm{U}-\mathrm{Pb}$ e $\mathrm{Rb}-\mathrm{Sr}$ no Cráton do São Francisco Meridional: Evidências a partir do Complexo Bonfim Setentrional, Quadrilátero Ferrifero, Minas Gerais. In: CONGRESSO BRASILEIRO DE GEOLOGIA, 37, São Paulo, 1992. Boletim de Resumos...São Paulo, SBG, p. 189-188.

CHAPEL, B.W. \& WHITE, A.J.R. 1974. Two contrasting types of granites. Pacific Geology, 8:173-174.

CHEMALE JR., F.; ROSIÈRE, C.A.; ENDO, I. 1991. Evolução tectônica do Quadrilátero Ferrifero Minas Gerais-Um modelo. Pesquisas, 18(2):104-127.

CHEMALE JR., F.; ROSIĖRE, C.A.; ENDO, I. 1994. The tectonic evolution of the Quadrilatero Ferrifero, Minas Gerais, Brazil. Precambrian Research, 65:25-54.

CHEMALE JR.. F.: BABINSKI. M.: VAN SCHMUS, W.R. 1993. U/Pb dating of granitic-gneissic rocks from the Belo Horizonte and Bonfim complexes, Quadrilátero Ferrifero (Brazil). Report for CNPq and NSF-EAR Project on São Francisco Craton Margin Transect Project. 16p. (inédito).
CHILDE, F.; DOIG. R.; GARIÉPY. C. 1993. Monazite as a metamorphic chronometer. south of the Grenville Front, western Quebec. Canadian Journal of Earth Sciences, 30:1056-1065.

CHOUDHURI, A.; CRÓSTA, A.P.; SCHRANK. A.; SZABÓ, G.A.J.; IYER. S.S. 1992. The Quilombo granite in the Archean Morro do Ferro greenstone belt. SW Minas Gerais, and regional character of the transamazonian event. Revista Escola de Minas, 45(1/2):152-154.

CONDIE, K.C. 1991. Archean Greenstone Belts. Amsterdan, Eisevier. 434p.

CONDIE, K.C. 1982. Early and Middle Proterozoic supracrustal successions and their tectonic settings. American Journal of Science, 282:341-357.

COPELAND, P.; PARRISH, R.R.; HARRISON, T.M. 1988. Identification of inherited radiogenic $\mathrm{Pb}$ in monazite and implications for $\mathrm{U}-\mathrm{Pb}$ systematics. Nature, 333:760-763.

CORDANI, U.G.; TEIXEIRA, W.; SIGA Jr; O. 1980. Geocronologia do Quadrilátero Ferrífero. In: SEMANA DE ESTUDOS DA SICEG, 21. Ouro Preto, 1980. Boletim...Ouro Preto, SICEG, p.27-44 (Boletim 21, 1989).

CORDANI, U.G.; SATO, K.; MARINHO, M.M. 1985. The geologic evolution of the ancient granitegreenstone terrane of central-southern Bahia, Brazil. Precambrian Research, 27:187-213.

CORFU, F. 1987. Inverse age stratification in the Archean crust of the Superior Province: evidence for infra- and subcrustal accretion from high resolution $\mathrm{U}-\mathrm{Pb}$ zircon and monazite ages. Precambrian Research, 36:259275.

CORFU, F. 1988. Differential response of U-Pb systems in coexisting accessory minerals, Winnipeg River Subprovince, Canadian Shield: implications for Archean crust growth and stabilization. Contributions to Mineralogy and Petrology, 98:312-325.

CORFU, F. 1993. The evolution of the southern Abitibi greenstone belt in light of precise $\mathrm{U}-\mathrm{Pb}$ geochronology. Economic Geology, 88;1323-1340.

CORFU, F.; KROGH, T.E.; AYRES, L.D. 1985. U-Pb zircon and sphene geochronology of a composite Archean granitoid batholith, Favourable Lake area, northwestern Ontario. Canadian Journal of Earth Sciences, 22:1436-1451.

CORFU, F. \& STOTT, G.M. 1986. U.Pb ages for late magmatism and regional deformation in the Shebandowan Belt, Superior Province, Canada. Canadian Journal of Earth Sciences, 23:1075-1082.

CORFU, F. \& MUIR, T.L. 1989. The Hemio-Herron Bay greenstone belt and Hemio Au-Mo deposit. Superior province, Ontario, Canada 2: Timing of metamorphism. alteration and Au mineralization from titanite, rutile and monazite $\mathrm{U}-\mathrm{Pb}$ geochonology. Chemical Geology, 79:201-223. 
COSTA. M.T. 1961. Sedimentação e orogênese da Série de Minas. In: SEMANA DE ESTUDOS DA SICEG, 1 . Ouro Preto. 1961. Boletim...Ouro Preto, SICEG, p.5561 (Boletim 1).

CROCCO-RODRIGUES, F.A.: RIBEIRO-RODRIGUES: L.C.; ROSIĖRE, C.A. 1992. Análise crítica sobre a controvérsia do Grupo Tamanduá, Quadrilátero Ferritero. Revista Escola de Minas, 45 (1/2):47-48.

DAVIS, D.W. 1982. Optimum linear regression and error estimation applied to U-Pb data. Canadian Journal of Earth Sciences, 19:2141-2149.

DAVIS, D.W.; BLACKBURN, C.E.; KROGH, T.E. 1982. Zircon $U-\mathrm{Pb}$ ages from the Wabigoon-Manitou lakes region. Wabigoon Subprovince, northwest Ontario. Canadian Journal of Earth Sciences, 19:254- 266.

DAVIS, D.W. \& JACKSON, M.C. 1988. Geochronology of the Lumby Lake greenstone belt: A 3 Ga complex within the Wabigoon subprovince, northwest Ontario. Geological Society of America Bulletin, 100:818-824.

DAVIS, D.W.; POULSEN, K.H.; KAMO, S.L. 1989. New insights into Archean crustal development from geochronology in the Rainy Lake area, Superior Province, Canada. Journal of Geology, 97:379-398.

DAVIS, D.W.; PEZZUTTO, F.; OJAKANGAS, R.W. 1990. The age and provenance of metasedimentary rocks in the Quetico Subprovince, Ontario, from single zircon analyses: implications for Archean sedimentation and tectonics in the Superior Province, Earth and Planetary Science Letters, 99:195-205.

DAVIS, G.H \& CONEY, P.J. 1979. Geologic development of the cordilleran metamorphic core complexes. Geology, 7:120-124.

DELHAL, J \& DEMAIFFE, D. 1985. U/Pb Archean geochronology of the São Francisco Craton (eastern Brazil). Revista Brasileira de Geociências, 15(1):5560.

DELOULE, E.; GARIÉPY, C.; DUPRÉ, B. 1989. Metallogenesis of the Abitibi greenstone belt of Canada: a contribution from the analysis of trace lead in sulfide minerals. Canadian Journal of Earth Sciences, 26:2529-2540.

DE PAOLO. D.J. 1988. Neodymiun isotope geochemistry: an introduction. Berlin, Springer-Verlag. $187 \mathrm{p}$. (Minerals and rocks, 20).

DE WIT, M.J.; HART, R.A.; HART, R.J. 1987. The Jamestown Ophiolite Complex, Barberton mountain belt: a section through $3.5 \mathrm{Ga}$ oceanic crust. Journal of African Earth Sciences, 6:681-730.

DEWITT, E.; LANDIS, G.P.; ZARTMAN, R.E.; THORMAN. C.H.: GARAYP. E.: PEREIRA. S.M.: BUENO DO PRADO. M.G., VIEIRA, F.W.R. 1994. Isotopic and fluid inclusion data on the age of the São Bento and Morro Velho gold deposits, Minas Gerais, Brazil. Internal report, $5 p$.
DORR II. I.V.N. 1969. Phisiographic. stratigraphic and structural development of the Quadrilatero Ferrifero. Minas Gerais, Brazil. U.S. Geological Survey Professional Paper. 641-A:1-110.

DORR II, J.V.N.; GAIR, J.E.; POMERENE, I.G.; RYNEARSON, G.A. 1957. Revisão da estratigratia pré-cambriana do Quadrilátero Ferrifero. Departamento Nacional da Produção Mineral. Divisão de Fomento da Produção Mineral, 81:1-31 (Avulso).

DOSSIN, I.A.; DOSSIN, T.M.; CHARVET, J.; COCHERIE, A; ROSSI, P. 1993. Single-zircon dating by step-wise Pb-evaporation of Middle Proterozoic magmatism in the Espinhaço range, southeastern Sao Francisco Craton (Minas Gerais, Brazil). In: SIMPÓSIO SOBRE O CRÁTON DO SÃO FRANCISCO, 2, Salvador, 1993. Inais... Salvador. SBG/SGM, p.39.42.

DRAKE. A.A. \& MORGAN, B.A. 1980. Precambrian plate tectonics in the Brazilian Shield-evidence from the pre-Minas rocks of the Quadrilatero Ferrifero, Minas Gerais. U.S. Geological Survey Professional Paper, 1119-B:1-19.

EBERT, H. 1957. Beitrag zur des Prakambriums in Minas Gerais. Geologische Rundschau, 45:451-521.

EVENSEN, N.M.; HAMILTON, P.J.; O'NIONS, R.K. 1978. Rare-earth abundances in chondritic meteorites. Geochimica et Cosmochimica Acta, 42:1199-1212.

FENG, R.; MACHADO, N.; LUDDEN, J. 1993. Lead geochronology of zircon by Laser Probe-Inductively Coupled Plasma Mass Spectrometry (LP-ICPMS). Geochimica et Cosmochimica Acta, 57:3479-3486.

FERRARI, P.G. 1980. Considerações geológicas da taixa bordejante à Serra do Curral entre lbirité e a Serra da Piedade. In: SEMANA DE ESTUDOS DA SICEG. 21, Ouro Preto, 1980. Boletim...Ouro Preto, SICEG, p.80-98 (Boletim 21, 1989).

FIGUEIREDO, M.C.H. \& BARBOSA, J.S.F. 1993. Terrenos metamórficos de alto grau do Cráton do São Francisco. In: DOMINGUEZ, J.M.L \& MISI, A. (eds), $O$ Cráton do São Francisco. Salvador, SBG-SGMCNPq, p.63-84.

FOGACA, A.C.C.; ABREU, P.A.A.; SCHORCHER, H.D. 1984. Estratigrafia da sequência supracrustal arqueana na porção mediana-central da Serra do Espinhaço, Minas Gerais. In: CONGRESSO BRASILEIRO DE GEOLOGIA, 32, Rio de Janeiro, 1984. Anais... Rio de Janeiro, SBG, p.2654-2667.

FREITAS, M.E.F.; CROCCO-RODRIGUES, F.A.; ROSIÈRE, C.A. 1992. A correlação do Quartzito Cambotas com a Sequência Espinhaço apoiada por mapeamento geológico $\mathrm{em}$ escala 1:10.000. Revista Escola de Minas. 45(1/2):51-53.

FUCK. R.A. 1991a. Aprovada nova escala de tempo para o Pré-Cambriano. Revista Brasileira de Geociências. 21(2): 182-183. 
FUCK. R.A. 199lb. Subdivisão cronometrica do Arqueano: proposta da Subcomissão de Estratigratia do Pré-Cambriano. Revista Brasileira de Geociências. 21(2): 184-185.

GAIR. J.E. 1962. Geology and ore deposits of the Nova Lima and Rio Acima quadrangles. U.S. Geological Survey Professional Paper, 341-A:1-87.

GARIÉPY, C.: ALLEGRE, C.J.; LAJOIE, J. 1984. U-Pb systematics in single zircons from the Pontiac sediments, Abitibi greenstone belt. Canadian Journal of Earth Sciences, 21:1296-1304.

GOODWIN, A.M. 1991. Precambrian geology: The dynamic evolution of the continental crust. London, Academic Press, $666 \mathrm{p}$.

GOSSELIN, D.C.; PAPIKE, J.J.; SHEARER, C.K.; PETERMAN, Z.E.; LAUL, J.C. 1990. Geochemistry and origin of Archean granites from the Black Hills, South Dakota. Canadian Journal of Earth Sciences, 27:57-71.

GROSSI SAD, J.H.; PINTO, C.P.; DUARTE, C.L. 1983. Geologia do distrito manganesifero de Conselheiro Lafaiete, MG. In: SIMPÓSIO DE GEOLOGIA DE MINAS GERAIS, 2, Belo Horizonte, 1983. Anais... Belo Horizonte, SBG-MG, p.259-270 (Boletim 3).

GROSSI SAD, J.H. \& DUTRA, C.V. 1989. Fracionamento dos elementos terras-raras e suas aplicações em metalogênese. In: FORMOSO, M.L.; NARDI, L.V.S.; HARTMANN, L. (eds.), Geoquímica dos elementos terras-raras no Brasil. Rio de Janeiro, CPRM-DNPM, Sociedade Brasileira de Geoquímica, p.132-142.

GUILD, Ph. 1957. Geology and mineral resources of the Congonhas district, Minas Gerais, Brazil. U.S. Geological Survey Professional Paper, 290:1-90.

GUIMARÃES, D. 1931. Contribuiçăo à geologia do Estado de Minas Gerais. Serviço Geológico e Mineralógico, 55:1-36 (Boletim).

HAGER, J.W. 1989. Relative elemental responses for laser ablation inductively coupled plasma mass spectrometry. Analytical Chemistry, 61:1243-1248.

HEAMAN, L. \& PARRISH, R. 1991. U-Pb geochronology of accessory minerals. In: HEAMAN, L. \& LUDDEN, J.N. (eds), Short Course Handbook on Applications of Radiogenic Isotope Systems to Problems in Geology. Toronto, Mineralogical Association of Canada, p.59102.

HEILBRON, M.; GONCALVES, M.L.; TEIXEIRA, W.; TROUW, R.A.J.; PADILHA, A.V.; KAWASHITA, K. 1989. Geocronologia da região entre Lavras, São João del Rei. Lima Duarte e Caxambu. Anais da Academia Brasileira de Ciências, 61(2):177-199.

HERZ. N. 1970. Gneissic and igneous rocks of the Quadrilátero Ferrifero, Minas Gerais, Brazil. U.S. Geological Survey Professional Paper, 641-B:1-58.
HERZ. N. 1978. Metamorphic rocks of the Quadrilátero Ferrifero, Minas Gerais. Brazil. U.S. Geological Survey Professional Paper, 641-C:1-81.

HERZ, N.; HURLEY, P.M.; PINSON, W.H.; FAIRBAIRN, H.W. 1961. Age measurements from a part of the Brasilian shieid. Geological Society of America Bulletin, 72:1111-1120.

HILL, R.I.; CAMPBELL, I.H.: CHAPPELL, B.H. 1992. Crustal growth, crustal reworking, and granite genesis in the southeastern Yilgarn block, Western Australia. The University of Western Australia, Publ., 22:203212.

HOFFMAN, P.F. 1988. United Plates of North America, the birth of a craton: Early Proterozoic assembly and growth of Laurentia. Annual Reviews of Earth an Planetary Sciences, 16:543-603.

HOMEWOOD, P. \& LATELTIN, O. 1988. Classic swiss clastics (flysch and molasse): The alpine connection. Geodinamica Acta, 2:1-11.

HOUSH, T. \& BOWRING, S.A. 1991. Lead isotopic heterogeneities within alkali feldspars: Implications for the determination of initial lead isotopic compositions. Geochimica et Cosmochimica Acta, 55:2309-2316

JAHN, B. \& SCHRANK, A. 1983. Ree geochemistry of komatiite and associated rocks from Piumhi, southeasthern Brazil. Precambrian Research, 21:1-20.

JORDT-EVANGELISTA, H. 1992. A Formação Sabará, Supergrupo Minas, Quadrilátero Ferrífero: Contribuição à petrografia e geoquímica. In: CONGRESSO BRASILEIRO DE GEOLOGIA, 37, São Paulo, 1992. Boletim de Resumos...São Paulo, SBG, p. 412-413.

KAWASHITA, K.; SONOKI, I.K.; SATO, K.; SONOKI, H.M. Regressões lineares em geocronologia: isócronas, errócronas e pseudoisócronas. Boletim Instituto de Geociências-USP, Série Científica, 21:5372.

KROGH, T.E. 1973. A low contamination method for hydrothermal decomposition of zircon and extraction of $\mathrm{U}$ and $\mathrm{Pb}$ for isotopic age determination. Geochimica et Cosmochimica Acta, 37: 488-494.

KROGH, T.E. 1982a. Improved accuracy of U-Pb zircon dating by selection of more concordant fractions using a high gradient magnetic separation technique. Geochimica et Cosmochimica Acta, 46:631-635.

$\mathrm{KROGH}$, T.E. $1982 \mathrm{~b}$. Improved accuracy of U-Pb zircon ages by the creation of more concordant systems using an air abrasion technique. Geochimica et Cosmochimica Acta, 46:637-649.

KROGH, T.E. \& DAVIS, G.L. 1975. The production and preparation of $205 \mathrm{~Pb}$ for use as a tracer for isotope dilution analysis. Carnegie Institute Washington Yearbook, 74: 416-417. 
KROGH. T.E. \& TUREK. A. 1982. Precise U-Pb zircon ages from the Gamitagama greenstone belt, southern Superior Province. Canadian Journal of Earth Sciences, 19:859-867.

LACERDA, M.P.C.; CORREIA NEVES. J.M.; BILAL, E. 1993. Granitóides pré-cambrianos da região de Moeda e Belo Vale-Complexo Moeda (QF $\leadsto \mathrm{MG})$. In: SIMPÓSIO SOBRE O CRÁTON DO SÃO FRANCISCO, 2, Salvador. 1993. Anais... Salvador, SBG/SGM, p.93-96.

LADEIRA, E.A. 1976. Principais feições tectônicas do Escudo Brasileiro. In: LOCZY, L. \& LADEIRA, E.A. Geologia Estrutural e Introdução à Geotectônica. São Paulo, Ed. Edgard Blücher, p.431-462.

LADEIRA, E.A. 1980. Metallogenesis of gold at the Morro Velho Mine and in Nova Lima District, Quadrilátero Ferrifero. Minas Gerais, Brazil. London (Ontario), 272 p. (PhD Thesis, University of Western Ontario).

LADEIRA, E.A. 1981. Primeiras lavas com almofadas (pillows) encontradas no Supergrupo Rio das Velhas, de idade arqueana, no Quadrilátero Ferrifero e no Distrito de Pitangui, Minas Gerais. Ciências da Terra, 1:12-14.

LADEIRA, E.A. \& VIVEIROS, J.F.M. 1984. Hipótese sobre a estruturação do Quadrilátero Ferrífero com base nos dados disponiveis. Sociedade Brasileira de Geologia-Núcleo Minas Gerais, 4:1-14 (Boletim)

LADEIRA, E.A. \& VIVEIROS, J.F.M. 1986. Introduction to the geology of the Quadrilatero Ferrifero and hypoteses regarding its regional structure. In: THORMAN, C.H.; LADEIRA, E.A.; SCHNABEL, D.C. (eds.), Gold deposits related to greenstone belts in Brazil. Deposits Modeling Workshop (Part B), United States Geological Survey (unpublished).

LEAKE, B.E. 1990. Granite magmas: their sources, initiation and consequences of emplacement. Journal of the Geological Society London, 147:579-589.

LEDRU, P.; COCHERIE, A.; BARBOSA, J. 1993. Ages du métamorphisme granulitique dans le Cráton du São Francisco (Brésil), implications sur la nature de l'orogene transamazonien. In: SIMPÓSIO SOBRE O CRÁTON DO SÃO FRANCISCO, 2, Salvador, 1993. Anais... Salvador, SBG/SGM, p. 17.

LUDWIG, K.R. 1983. Plotting and regression programs for isotope geochemists, for use with HP-86/87 microcomputers. U.S. Geological Survey Open-File Reports, 83:849-894.

LUDWIG, K.R. 1990. A plotting and regression program for radiogenic-isotope data, for IBM-PC compatible computers. U.S. Geological Survey Open-File Reports. 88-557:1-44.

MACHADO F॰, L.: RIBEIRO. M.W.; GONZALEZ, S.R.: SCHENINI, C.A.; NETO, A.S.: PALMEIRA, R.C.B.; TEIXEIRA. W.; CASTRO, H.E.F. 1983. Geologia. In: PROJETO RADAMBRASIL, Folhas SF.23/2 4 Rio de
Janeiro e Vitória. Rio de Janeiro. DNPM/MME/SG. p.27-304. (Levantamento de Recursos Naturais. 32).

MACHADO, N.; NOCE. C.M.: BELO DE OLIVEIRA. O.A.; LADEIRA, E.A. 1989a. Evolução geológica do Quadrilátero Ferrifero no Arqueano e Proterozóico Inferior com base em geocronologia U-Pb. In: SIMPÓSIO DE GEOLOGIA DE MINAS GERAIS. 5, Belo Horizonte. 1989. Anais... Belo Horizonte. SBGMG, p.1-4 (Boletim 10).

MACHADO, N.: SCHRANK, A.; ABREU, F.R., KNAUER, L.G.; ALMEIDA-ABREU, P.A. 1989b. Resultados preliminares da geocronologia $\mathrm{U} / \mathrm{Pb}$ na Serra do Espinhaço Meridional. In: SIMPÓSIO DE GEOLOGIA DE MINAS GERAIS, 5, Belo Horizonte, 1989. Anais... Belo Horizonte, SBG-MG, p.1-4 (Boletim 10).

MACHADO, N.; GOULET, N.; GARIÉPY, C. 1989c. U$\mathrm{Pb}$ geochronology of reactivated Archean basement and of Hudsonian metamorphism in the northern Labrador Trough. Canadian Journal of Earth Sciences, 26:1-15.

MACHADO, N. \& SCHRANK, A. 1989. Geocronologia $\mathrm{U} / \mathrm{Pb}$ no Maciço de Piumhi-Resultados preliminares. In: SIMPÓSIO DE GEOLOGIA DE MINAS GERAIS, 5, Belo Horizonte, 1989. Anais... Belo Horizonte, SBG-MG, p.45-49 (Boletim 10).

MACHADO, N.; NOCE, C.M.; LADEIRA, E.A.; BELO DE OLIVEIRA, O.A. 1992. U-Pb geochronology of Archean magmatism and Proterozoic metamorphism in the Quadrilatero Ferrifero, southern São Francisco Craton, Brazil. Geological Society of America Bullettin, 104:1221-1227.

MACHADO, N. \& CARNEIRO, M.A. 1992. U-Pb evidence of late Archean tectono-thermal activity in the southern São Francisco shield, Brazil. Canadian Journal of Earth Sciences, 29:2341-2346.

MACHADO, N \& NOCE, C.M. 1993. A evolução do setor sul do Cráton do São Francisco entre 3,1 e $0,5 \mathrm{Ga}$ baseada em geocronologia U-Pb. In: SIMPÓSIO SOBRE O CRÁTON DO SÃO FRANCISCO, 2, Salvador, 1993. Anais... Salvador, SBG/SGM, p. 100105.

MACHADO, N; NOCE, C.M.; FENG, R. 1993. Idades $207 \mathrm{~Pb} / 206 \mathrm{~Pb}$ de zircòes detríticos de rochas metasedimentares da região do Quadrilátero Ferrifero, sul do Cráton do São Francisco. Considerações sobre áreas-fonte e idades de sedimentação. In: SIMPÓSIO SOBRE O CRÁTON DO SÃO FRANCISCO, 2, Salvador, 1993. Anais... Salvador, SBG/SGM, p. 149151.

MANHÈS, G.; ALLĖRE, C.J.; DUPRÉ. B.; HAMELIN, B. 1980. Lead isotope study of basic-ultrabasic layered complexes: Speculations about the age of the earth and primitive mantle characteristics. Earth and Planetary Science Letters, 47:370-382.

MARSHAK, S. \& ALKMIM, F.F. 1989. Proterozoic extension/contraction tectonics of the southern São 
Francisco craton and adjacent regions. Minas Gerais. Brazil: a kinematic model relating Quadrilátero Ferrifero, São Francisco basin and Cordilheira do Espinthaço. Tectonics, 8:555+571.

MARSHAK. S.; ALKMIM. F.F.; JORDTEVANGELISTA. H. 1992. Proterozoic crustal extension and the generation of dome-and-keel structure in an Archaean granite-greenstone terrane. Nature, 357:491-493.

MARTIN, H. 1987. Archean and modern granitoids as indicators of changes in geodynamic processes. Revista Brasileira de Geociências, 17(3/4):360-365.

MARTIN, H. 1990. Geochemical investigations of Archean basement terranes. In: CONGRESSO BRASILEIRO DE GEOLOGIA, 36, Natal. 1990. Curso...Natal. SBG, p.1-107.

MATTINSOM, J.M. 1978. Age, origin, and thermal histories of some plutonic rocks from the Salinian Block of California. Contributions to Mineralogy and Petrology, 67:233-245.

MEZGER, K.: HANSON, G.N.; BOHLEN, S.R. 1989. High-precision $\mathrm{U}-\mathrm{Pb}$ ages of metamorphic rutile: application to the cooling history of high-grade terranes. Earth and Planetary Science Letters, 96:106118.

MORAES, M.A.S. 1985. Reconhecimento de fácies sedimentares em rochas metamórficas da região de Ouro Preto (MG). In: SIMPÓSIO DE GEOLOGIA DE MINAS GERAIS, 3, Belo Horizonte, 1985. Anais... Belo Horizonte, SBG-MG, p.84-93 (Boletim 5).

MOTTA. E.G.M.: SAMPAIO, J.C.D.; MOURA, M.M.; COSTA, S.M.S. 1989. Mapeamento geológico da porção ocidental da Folha Serra da Piedade, Quadrilátero Ferrifero (MG). Belo Horizonte. 69 p. (Relatório de Graduação, Universidade Federal de Minas Gerais).

NOCE, C.M.; PINHEIRO, S.O.; LADEIRA, E.A.; GROSSI SAD. J.H. 1990. Ocorrência de metakomatiitos com textura "spinifex" no Grupo Nova Lima, oeste do Quadrilátero Ferrífero, MG. In: CONGRESSO BRASILEIRO DE GEOLOGIA. 36, Natal, 1990. Boletim de Resumos...Natal, SBG, p.215.

NOCE, C.M.; PINHEIRO, S.O.; LADEIRA, E.A.; FRANCA, C.R.; KATTAH, S. 1992. A sequência vulcanossedimentar do Grupo Nova Lima na regiăo de Piedade do Paraopeba, oeste do Quadrilátero Ferrifero, Minas Gerais. Revista Brasileira de Geociências, 22(2): 175-183.

NUMMER, A.; SEIXAS, L.A.R.; BAARS, F.J.; ALMEIDA, M.E.; FERREIRA. A.L.; MARTINS. A.P.S.; MONTEIRO, M.A.S.: PAIXÃO, M.A.P.: SIROTHEAU, G.J.C.: TASSO. M.A.L. 1992. Geologia estrutural e petrologia do Lineamento Congonhas-MG. In: CONGRESSO BRASILEIRO DE GEOLOGIA. 37. São Paulo. 1992. Boletim de Resumos...São Paulo, SBG, p.353-355.
NUNES, P.D. \& THURSTON. P.C. 1980. 'Two hundred and twenty million years of Archean evolution: a zircon $\mathrm{U}-\mathrm{Pb}$ age stratigraphic study of the UchiConfederation lakes greenstone beit. northwestern Ontario. Canadian Journal of Earth Sciences. $17: 710.721$

NUNN, G.A.G.; HEAMAN, L.M.; KROGH, T.E. 1990. U$\mathrm{Pb}$ geochronological evidence for Archean crust in the continuation of the Rae Province (eastern Churchill Province), Grenville front tectonic zone, Labrador. Geoscience Canada, 17:259-264.

O'CONNOR. J.T. 1965. A classification of quartz-rich igneous rocks based on feldspar ratios. U.S Geological Survey Professional Paper. 525-B:79-84.

OLIVEIRA, G.A.I.: CLEMENTE, P.L.C.; VIAL. D.S 1983. Excursão à mina de ouro de Morro Velho. In: SIMPÓSIO DE GEOLOGIA DE MINAS GERAIS. 2 , Belo Horizonte, 1983. Anais... Belo Horizonte. SBGMG, p.497-505 (Boletim 3).

PARRISH, R.R. 1990. U-Pb dating of monazite and its application to geological problems. Canadian Journal of Earth Sciences, 27:1431-1450.

PEARCE, J.A.; HARRIS, N.B.W.; TINDLE, A.G. 1984. Trace element discrimination diagrams for the tectonic interpretation of granitic rocks. Jounal of Petrology, 25:956:983.

PEDROSA-SOARES, A.C.; DARDENNE, M.A.; HASUY, I.; CASTRO, F.D.C.; CARVALHO, M.V.A.; REIS, A.C. 1994. Mapa geológico do Estado de Minas Gerais, escala 1:1.000.000. Belo Horizonte, COMIG,

PETRI, S.; COIMBRA, A.M.; AMARAL, G.; PONÇANO. W.L. 1986. Guia de nomenclatura estratigrática. Revista Brasileira de Geociencias, 16(4): 376-415.

PINTO, C.P. \& DUARTE, C.L. 1978. Geologia do precambriano da porção centro-sul do Estado de Minas Gerais (Folhas de Entre Rios de Minas, Conselheiro Lafaiete, Ouro Branco, Resende Costa, Carandaí e Tiradentes). Cia. Meridional de Mineração (Relatório inédito), 48p.

PIRES, F.R.M. 1977. Geologia do distrito manganesifero de Conselheiro Lafaiete, Minas Gerais. Rio de Janeiro, 344p. (Dissertação de Mestrado, Universidade Federal do Rio de Janeiro).

PIRES, F.R.M. \& BARBOSA, M.I.M. 1993. O limite meridional do Cráton do São Francisco e o posicionamento de granitos colisionais. In: SIMPÓSIO SOBRE O CRÁTON DO SÃO FRANCISCO, 2, Salvador, 1993. Anais... Salvador. SBG/SGM, p. 33-38.

POMERENE. J.B. 1964. Geology of Belo Horizonte. Ibirité and Macacos quadrangles. U.S. Geological Survev Professional Paper, 341-D:1-84.

QUÉMÉNEUR, J.J.G. \& VIDAL, Ph. 1989. Primeiras datações radiométricas dos granitos de São João del Rei. In: SIMPÓSIO DE GEOLOGIA DE MINAS 
GERAIS, 5, Belo Horizonte. 1989. Inais... Belo Horizonte. SBG-MG, p.50-54 (Boletim 10).

QUÉMÉNEUR. J.J.G. \& GARCIA, D. 1993 Os maciços de Tabuões e Ritápolis na região de Săo João del Rei. granitóides transamazônicos com a associaçào granitotrondhjemito-pegmatito. In: SIMPÓSIO DE GEOLOGIA DE MINAS GERAIS, 7, Belo Horizonte, 1993. Anais... Belo Horizonte, SBG-MG. p.105-107.

RENGER, F.E.: SUCKAU, V.E.; SILVA, R.M.P. 1993. Sedimentologia e análise de bacia da Formação Moeda, Quadrilátero Ferrifero, Minas Gerais. Brasil. In: SIMPÓSIO DE GEOLOGIA DE MINAS GERAIS, 7, Belo Horizonte, 1993. Anais... Belo Horizonte, SBG-MG, p.41-45.

RENGER, F.E.; NOCE. C.M.; ROMANO, A.W.: MACHADO, N. 1994. Evolução sedimentar do Supergrupo Minas (500 Ma de registro geológico), Quadrilátero Ferrifero, Minas Gerais, Brasil. Geonomos, 2:1 111.

RIBEIRO-RODRIGUES, L.C.; CHEMALE Jr., F.; JOST, H. 1993. Posicionamento estratigráfico dos quartzitos da Serra do Caraça. In: SIMPÓSIO DE GEOLOGIA DE MINAS GERAIS, 7, Belo Horizonte, 1993. Anais... Belo Horizonte, SBG-MG, p.34-38.

RICHARDS, JP.; KROGH, T.E.; SPOONER, E.T.C. 1988. Fluid inclusion characteristics and $\mathrm{U}-\mathrm{Pb}$ rutile age of late hydrothermal alteration and veining at the Musoshi stratiform cooper deposit, Central Africa cooper belt, Zaire. Economic Geology, 83:118-139.

ROBB. L.J. 1983. Geological and chemical characteristics of late granite plutons in the Barberton region and Swaziland with an emphasis on the Dalmein pluton: $A$ review. Special Publication Geological Society of South Africa, 9:153-167.

ROBB, L.J.; DAVIS, D.W. ; KAMO, S.L. 1990. U-Pb ages on single detrital zircon grains from the Witwatersrand Basin. South Africa: constraints on the age of sedimentation and on the evolution of granites adjacent to the basin. Journal of Geology, 98:311-328.

ROESER. H.M.P.; ALKMIM, F.F.; EVANGELISTA. H.J.; COELHO, J.; MENEZES, M.G.; VARAJÄO, C.C.; SOUZA, J.L.; FERREIRA, C.M.; GOMES. N.S. 1987. Quadrilátero Ferrifero. In: CONGRESSO BRASILEIRO DE GEOQUIMICA, 2, INTERNATIONAL GEOCHEMICAL CONGRESS, 13. Rio de Janeiro. 1989. Excursions... Rio de Janeiro, SBGq-CPRM/DNPM, p.11-43.

ROMANO. A.W. 1989. Evolution tectonique de la région NW du Ouadrilatère Ferrifere - Minas Gerais, Brésil. Nancy, 259 p. (Thèse Docteur, Université de Nancy 1).

ROMANO, A.W.: BERTRAND, J.M.; MICHARD. A.; ZIMMERMANN. J.L. 1991. Tectonique tangentielle it décrochements d'âge Protérozoïque intérieur (orogenèse transamazonienne. environ $2000 \mathrm{Ma}$ ) au Nord du "Quadrilatère ferrifère" (Minas Gerais. Brésil). Comptes Rendus de l'Académie des Sciences de Paris, 313:1195-1200.
ROMANO. A.W.: ROSIERE. C.A.: COSTA. R.D. 1992. Duplo regime cinemático na regiào da Falha do Engenho, QF, MG. In: CONGRESSO BRASILEIRO DE GEOLOGIA, 37. São Paulo. 1992. Boletim de Resumos...São Paulo, SBG. p.360-361.

SAGER-KINSMAN, E.A. \& PARRISH, R.R. 1993. Geochronology of detrital zircons from the Elzevir and Frontenac terranes, Central Metasedimentary Beit. Grenville Province. Ontario. Canadian Journal of Earth Sciences, 30:465-473.

SATO. K. 1986. Síntese geocronológica do Estado da Bahia e evolução crustal, com base no diagrama de evolução de Sr e razões iniciais ${ }^{87} \mathrm{Sr} /{ }^{86} \mathrm{Sr}$. São Paulo. 124 p. (Dissertação de Mestrado, Universidade de São Paulo)

SATO, K.; 'TASSINARI, C.C.G.; KAWASHITA, K.: PETRONILHO. L. 1994. Método geocronológico SmNd no IG-USP e suas aplicaçōes. Anais da Academia Brasileira de Ciências (submetido para publicação).

SCHANDL. E.S.: DAVIS. D:W.; KROGH, T.E. 1990. Are the alteration halos of massive sulfide deposits syngenetic? Evidence from U-Pb dating of hydrothermal rutile at the Kidd volcanic center. Abitibi subprovince. Canada. Geology, 18:505-508.

SCHÄRER, U.; KROGH, T.E; GOWER, C.F. 1986. Age and evolution of the Grenville Province in eastern Labrador from U-Pb systematics in accessory minerals. Contributions to Mineralogy and Petrology, 96:438-451.

SCHORSCHER, H.D. 1978. Komatiitos na estrutura "Greenstone Belt" Série Rio das Velhas, Qudrilátero Ferrifero, Minas Gerais. Brasil. In: CONGRESSO BRASILEIRO DE GEOLOGIA, 30, Recile, 1978. Boletim de Resumos...Recife, SBG, p. 292-293.

SCHORSCHER, H.D. 1992. Arcabouço petrográfico $e$ evolução crustal de terrenos pré-cambrianos do nordeste de Minas Gerais: Quadrilátero Ferrifero. Espinhaço Meridional e dominios granito-gnáissicos adjacentes. São Paulo, 394p. (Tese de Livre Docência. Universidade de São Paulo).

SCHORSCHER, H.D.; SANTANA, F.C.; POLONIA, J.C.: MOREIRA, J.M.P. 1982. Quadrilátero FerríferoMinas Gerais State: Rio das Velhas greenstone belt and proterozoic rocks. In: INTERNATIONAL SYMPOSIUM ON ARCHEAN AND EARLY PROTEROZOIC EVOLUTION AND METALLOGENESIS, Salvador, 1982. Excursions Annex...Salvador. SBG, 44 p.

SCHRANK, A. 1982. Petrologie des komatiites et des roches associées de la ceinture verte du Massif Precambrien de Piumhi (Minas Gerais-Brésil). Orsay, 272p. (Thèse Docteur-Ingenieur. Université de ParisSud).

SCHRANK, A. \& SILVA. M.G. 1993. Os greenstone-belts do Cráton do Så Francisco. In: DOMINGUEZ, J.M.L \& MISl, A. (eds), O Cráton do São Francisco. Salvador, SBG-SGM-CNPq, p. 85-118. 
SEIXAS. L.A.R. 1988. Geologia e metalotectos de ouro de uma fração do Lineamento Congonhas. Minas Gerais. Brasilia 119 p. (Dissertação de Mestrado. Universidade de Brasilia).

SIGA Jr., O. 1986. A evolução geotectônica da porção nordeste de Minas Gerais, com base em interpretações geocronológicas. Sao Paulo, 140p. (Dissertação de Mestrado, Universidade de São Paulo).

SILVA, A.M. KUYUMJIAN, R.; CHEMALE JR.: F? 1992. Enxames de dique máticos do Quadrilátero Ferrifero e Espinhaço Meridional. In: CONGRESSO BRASIlEIRO DE GEOLOGIA, 37, São Paulo, 1992. Boletim de Resumos Expandidos...São Paulo. SBG, v.1, p.505.

SIMMONS. G.C. 1968. Geology and iron deposits of the western Serra do Curral, Minas Gerais. Brazil. U.S. Geological Survey Professional Paper, 341-G:1-57.

SIMMONS, G.C. \& MAXWELL, C.H. 1961. Grupo Tamanduá da Série Rio das Velhas. Departamento Nacional da Produção Mineral-Divisão de Geologia e Mineralogia, 211:1-30 (Boletim).

SÖLLNER, F; LAMMERER, B.; WEBERDIEFENBACH, K. 1991. Die krustenentwicklung in der küstenregion nördlich von Rio de Janeiro/Brasilien. Münchner Geologische Hefte, 4:1100 .

STACEY, J.S. \& KRAMERS, J.D. 1975. Approximation of terrestrial lead isotope evolution by a two-stage model. Earth and Planetary Science Letters, 26:207221 .

STEIGER, R.H. \& JAGER, E. 1977. Subcommision on Geochronology: Convention on the use of decay constants in geo- and cosmochronology. Earth and Planetary Science Letters, 36:359-362.

TARNEY, J. \& SAUNDERS, A. 1990. Crustal growth mechanisms and mantle evolution. In: INTERNATIONAL ARCHAEAN SYMPOSIUM, 3, Perth, 1990. Extended Abstracts...Perth, Geoconferences (W.A.) Inc., p.451-452.

TEIXEIRA, W. 1982. Geochronology of the southern part of the Sao Francisco craton. Revista Brasileira de Geociências, 12(1/3):268-277.

TEIXEIRA, W. 1985. A evolução geotectônica da porção meridional do Cráton do São Francisco, com base em interpretações geocronológicas. São Paulo, 207 p. (Tese de Doutoramento, Universidade de São Paulo).

TEIXEIRA, W, 1993. Avaliação do acervo de dados geocronológicos e isotópicos do Cráton do São Francisco-implicações tectônicas. In: DOMINGUEZ, J.M.L \& MISI, A. (eds), O Cráton do São Francisco. Salvador, SBG-SGM-CNPq, p.11-34.

TEIXEIRA. W.: EVANGELISTA. H.J.: KAWASHITA. K.: BASEI, M.A.S.: TAYLOR, P.N. 1987. Complexo Granulitico de Acaiaca. MG: Idade, petrogènese e implicạ̧ões tectônicas. In: SIMPÓSIO DE
GEOLOGIA DE MINAS GERAIS, 4, Belo Horizonte. 1987. Anais... Belo Horizonte. SBG-MG, p.58-71.

TEIXEIRA, W.; KAWASHITA. K.; PECCHIO, M.: TAME, N.R. 1988. Geocronologia K-Ar do enxame de diques básicos da parte meridional do Cráton do São Francisco e implicaçōes no contexto geotectônico. In: CONGRESSO BRASILEIRO DE GEOLOGIA. 35. Belém, 1988. Anais...Belém. SBG, v.6, p.28702878.

TEIXEIRA, W \& FIGUEIREDO, M.C.H. 1991. An outline of Early Proterozoic crustal evolution in the Sto Francisco craton, Brazil: a review. Precambrian Research, 53:1-22.

TEIXEIRA. W; CARNEIRO, M.A.; NOCE, C.M.; MACHADO, N.; SATO, K.; TAYLOR, P.N. 1994. $\mathrm{Pb}, \mathrm{Sr}$ and $\mathrm{Nd}$ isotope constraints on the Archean evolution of gneissic-granitoid complexes in the southern São Francisco craton, Brazil. Precambrian Research (in press).

THORPE, R.I.; CUMMING, G.L.; KRSTIC, D. 1984. Lead isotope evidence regarding age of gold deposits in the Nova Lima district, Minas Gerais, Brazil. Revista Brasileira de Geociências, 14(3):147-152.

TUCKER, R.D.; RAHEIM, A.; KROGH, T.E.; CORFU, F. 1987. Uranium-lead zircon and titanite ages from the northern portion of the Western Gneiss Region, southcentral Norway. Earth and Planetary Sciences Letters, 81:203-211.

TUCKER, R.D. \& KROGH, T.E. 1988. Geochronological investigation of the Ingdal Granite Gneiss and discordant pegmatites from the Western Gneiss Region, Norway. Norsk Geologisk Tidsskrift, 68:201210

VIAL, D.S.; FERREIRA Jr., M.G.; FERRARI, P.G. 1987. A lapa seca na Mina de Morro Velho: Metavulcanitos alterados hidrotermalmente. In: SIMPÓSIO DE GEOLOGIA DE MINAS GERAIS, 4, Belo Horizonte, 1987. Anais... Belo Horizonte, SBG-MG, p.368-390 (Boletim 6).

VILAÇA, J.N. 1981, Alguns aspectos sedimentares da Formação Moeda. Sociedade Brasileira de GeologiaNúcleo Minas Gerais, 2:92-137 (Boletim).

WEISS, H. 1989. Sedimentologische, lithostratigraphische und tektonische Untersuchungen im Bereich der Santo Antônio-Fazies, SW Rand des Eisernen Vierecks, Minas Gerais, Brasilien. Clausthal, 160p. (Tese de Doutoramento, Technischen Universität Clausthal).

WIEDENBECK, M. 1990. The duration of tectono-thermal episodes in the late Archean: constraints from the northwestern Yilgarn craton, western Australia. In: INTERNATIONAL ARCHAEAN SYMPOSIUM. 3. Perth. $1990 . \quad$ Extended Abstracts...Perth. Geoconferences (W.A.) Inc. p.477-479.

WILLAMSON. J.H. 1968. Least-square fitting of a straight line. Canadian Jounal of Physics, 46:1845-1847. 
WINDLEY, B.F. 1984. The Evolving Continents. 2 ed. Chichester, John Wiley \& Sons. 399p.

WONG, L.; DAVIS, D.W.; HANES, J.A.; ARCHIBALD, D.A.; HODGSON, C.J.; ROBERT, F. 1989. An integrated $\mathrm{U}-\mathrm{Pb}$ and $\mathrm{Ar}-\mathrm{Ar}$ geochronological study of the Archean Sigma gold deposit, Val d'Or. Quebec. In: ANNUAL MEETING OF THE GEOLOGICAL ASSOCIATION OF CANADA AND MINERALOGICAL ASSOCIATION OF CANADA, 14, Montreal, 1989. Abstracts...Montreal, GAC-MAC, p. $45 \mathrm{~A}$. 